\title{
Katheterablation von Vorhofflimmern
}

\author{
Der medizinischen Fakultät der Universität Leipzig \\ eingereichte
}

\section{HABILITATIONSSCHRIFT}

\author{
zur Erlangung des akademischen Grades \\ doctor medicinae habilitatus
}

Dr. med. habil.

vorgelegt von

Dr. med. Christopher Piorkowski

geboren am 05.02.1975 in Cottbus

Verleihungsbeschluss: Leipzig, den 16. November 2010 


\title{
BIBLIOGRAPHISCHE BESCHREIBUNG
}

der Habilitationsschrift von Dr. med. Christopher Piorkowski

\author{
Katheterablation von Vorhofflimmern \\ Medizinische Fakultät der Universität Leipzig \\ 160 S., 63 Lit., 0 Abb., 11 Originalarbeiten
}

Bedingt durch die zunehmende Prävalenz der Rhythmusstörung Vorhofflimmern mit den assoziierten Morbiditäts- und Mortalitätsrisiken ist die Entwicklung und Etablierung kurativer Therapieverfahren von klinischem und wissenschaftlichem Interesse.

Entsprechend dem pathophysiologischen Verständnis der Arrhythmie-induzierenden Triggeraktivität und des Arrhythmie-erhaltenden Flimmersubstrat mit der vorrangigen anatomisch-strukturellen Lokalisation beider Entitäten im Übergangsbereich der großen Pulmonalvenentrichter in den posterioren linken Vorhof wurden katheterinterventionelle Ablationskonzepte als potentiell kurative Therapien entwickelt. Limitationen der praktischen Umsetzung theoretischer Linienkonzepte ergeben sich aus komplexen anatomischen Gegebenheiten und instabilen Zugangsbedingungen infolge Atmung und kardialer Mobilität.

Aufbauend auf non-fluoroskopischen Navigationssystemen wurden Verfahren für vollständig Modell-integrierte Ansätze der Ablationslinienplatzierung entwickelt, bei denen Planung, Durchführung und Validierung der Ablation an anatomisch korrekten dreidimensionalen CT-Modellen des linken Vorhofes erfolgen. Zur Verbesserung instabiler Zugangsbedingungen wurden Verfahren der Katheternavigation mittels 
steuerbaren Schleusensystemen eingeführt und in entsprechenden Studien mit klinischen Endpunkten validiert. Zu objektivierbaren Erfassung von Energietransfer und myokardialer Läsionsbildung während der Ablation wurden katheterinterventionelle Kontakttechnologien, die auf der Messung lokaler komplexer Impedanzen zwischen Katheter und Gewebe beruhen, in der ersten klinischen Anwendung erprobt und validiert.

Mit diesen technologischen Entwicklungen gelangen eine zunehmend akkuratere klinische Umsetzung theoretischer Ablationskonzepte und damit eine Etablierung des Therapiekonzeptes als klinisches Standardverfahren. Eine zur Abschätzung des Nutzen/Risiko-Profils nötige detaillierte Komplikationsanalyse stellte die Ösophagusverletzung als schwerste Komplikation heraus, die mit 0,3\% selten auftrat, aber für nahezu alle langfristigen Folgeschäden verantwortlich war. Entwicklungen zur periprozeduralen Visualisierung des Ösophagus mit paralleler intraösophagealer Temperaturmessung sind Ansätze zur Vermeidung dieser Komplikation in der Zukunft.

Bedingt durch das Auftreten und die postinterventionelle Zunahme asymptomatischer Flimmerrezidive ist die Frage eines objektiven Vorhofflimmermonitorings von entscheidender Bedeutung für die Beurteilung der Effektivität der Ablation sowie weitergehende klinische und wissenschaftliche Fragestellungen; wie die Indikation zur Antikoagulation oder den Vergleich von Rhythmus- und Frequenzkontrolle. 7Tage-LzEKGs und transtelephonische EKGs wurden als Standard zum Monitoring innerhalb klinischer Vorhofflimmerstudien etabliert. Entwicklungen im Bereich implantierbarer kontinuierlicher Rhythmusmonitore werden in Zukunft das Netz zur Erfassung asymptomatischen Vorhofflimmerns weiter verdichten. 


\section{Gliederung}

\section{Einführung}

1.1. Vorhofflimmern - Epidemiologie und Pathophysiologie 6

1.2. Klinische Therapieansätze für Patienten mit Vorhofflimmern 8

1.3. Entwicklung kurativer Behandlungsverfahren 10

2. Wissenschaftliche Hypothesen 14

3. Einführung in die durchgeführten wissenschaftlichen Untersuchungen

3.1. Technologische Entwicklungen zur Katheterablation von Vorhofflimmern

3.1.1. Dreidimensionale anatomische Orientierung

3.1.2. Stabilität und Kontakt des Katheterzuganges

3.2. Komplikationsrisiken der Katheterablation von Vorhofflimmern

3.3. Rhythmusmonitoring und Erfolgskontrolle nach Ablation

4. Originalarbeiten

4.1. Entwicklungen der Bildintegration und einer Modell-gestützten Therapie

4.1.1. Elektroanatomische Rekonstruktion des linken Vorhofes, der Pulmonalvenen und des Ösophagus im Vergleich zur realen Anatomie im multislice CT bei Patienten mit Vorhofflimmerablation

4.1.2. CT-Modell gestützte Ablation von Vorhofflimmern und atrialen Makro-Reentry-Tachykardien

4.1.3. Farb-kodiertes dreidimensionales „Entrainment Mapping“ zur Analyse und Therapie von atrialen Makro-Reentry-Tachykardien

4.2. Entwicklungen zu Katheterstabilität und objektivierbarem Wandkontakt

4.2.1. Katheternavigation mittels steuerbarer Zugangsschleuse bei Vorhofflimmerablation: Eine Case-Control Studie

4.2.2. Erste Validierung einer Impedanz-basierten Messung des Katheter-Gewebe Kontaktes im Menschen 
4.3. Risiken der katheterinterventionellen Therapie von Vorhofflimmern

4.3.1. Komplikationen der Vorhofflimmerablation in einer großen klinischen Patientenkohorte

4.3.2. Schnelles Erkennen und erfolgreiche Behandlung der

Ösophagusperforation nach Hochfrequenzablation von Vorhofflimmern

4.3.3. Einfluss der topographische Variabilität der anatomischen

Beziehung zwischen Ösophagus und linkem Vorhof auf die Ablationslinien

bei Patienten mit Vorhofflimmern

4.4. Einfluss der Vorhofflimmerperzeption auf das Monitoring nach Ablation

4.4.1. Wahrnehmung von Vorhofflimmern vor und nach katheterinterventioneller Radiofrequenzablation:

Relevanz asymptomatischer Arrhythmierezidive

4.4.2. Einfluss der Dauer der Langzeit-EKG-Aufzeichnung auf die Detektion von Arrhythmierezidiven nach Katheterablation von Vorhofflimmern:

Implikationen für die Nachkontrolle der Patienten

4.4.3. Wertigkeit verschiedener Monitoring-Strategien zur Bestimmung der Effektivität der zirkumferentiellen Pulmonavenenablation nach kurativer Behandlung von Vorhofflimmern

5. Diskussion und Ausblick

6. Literaturverzeichnis

7. Erklärung

8. Lebenslauf

9. Danksagung 


\section{Einführung}

\subsection{Vorhofflimmern - Epidemiologie und Pathophysiologie}

Vorhofflimmem ist die häufigste klinisch relevante Herzrhythmusstörung. Insbesondere im höheren Lebensalter zeigt sich ein deutlicher Anstieg der Prävalenz. Bereits aktuell leiden 6\% aller über 65 -jährigen und 10\% aller über 80 jährigen an der Rhythmusstörung ${ }^{1}$. Innerhalb der nächsten Dekaden ist mit einer weiteren Zunahme zu rechnen. Epidemiologisch basierte Schätzungen sagen eine Verdopplung bis Verdreifachung der Erkrankungsfälle voraus ${ }^{2}$. Die verbundenen Morbiditäts- und Mortalitätsrisiken sind seit der Framingham-Studie bekannt. So steigt die Mortalität auf nahezu das Doppelte gegenüber der Vergleichspopulation ${ }^{1}$. Diese Veränderung ist konstant in allen Altersgruppen und zeigt sich auch in der Subgruppe der Patienten ohne zusätzliche kardiovaskuläre Erkrankungen '. Unabhängig von der Mortalität steigt das Schlaganfallrisiko auf das 4 bis 5 -fache, wobei hier insbesondere die älteren Patienten betroffen sind ${ }^{3}$. Die orale Antikoagulation löst dieses Problem unter anderem aufgrund der assoziierten Blutungsgefahr nur teilweise ${ }^{4}$. Zudem leiden viele Patienten mit paroxysmalem oder persistierendem Vorhofflimmern erheblich unter den Symptomen der Rhythmusstörung und sind in ihrer Lebensqualität wesentlich beeinträchtigt.

Pathophysiologisch betrachtet entsteht Vorhofflimmern durch das kritische Zusammenspiel von Arrhythmie-induzierender Triggeraktivität und Arrhythmieerhaltendem Flimmersubstrat. So beschrieb Scherf bereits in den 1940-er Jahren die Möglichkeit der Induktion von Vorhofflimmern durch schnelle Erregungsbildung in einem einzelnen Fokus ${ }^{5}$. Diese Theorie wurde eindrucksvoll durch die Arbeiten der Gruppe um Michel Haissaguerre bestätigt ${ }^{6}$. In der überwiegenden Zahl der Patienten 
mit paroxysmalem Vorhofflimmern wiesen sie ektope Foci in den Pulmonalvenen nach, die durch schnelle Entladungen zu kurzen Episoden von Vorhofflimmern führten. Demgegenüber rücken bei länger anhaltenden Arrhythmiephasen und insbesondere bei Patienten mit persistierendem Vorhofflimmern Reentry-Phänomene und kreisende Erregungsfronten als so genanntes Vorhofflimmer-Substrat pathophysiologisch in den Vordergrund. Dieses Konzept wurde wesentlich geprägt durch die multiple Wellentheorie von Moe und Abildskov ${ }^{7}$. Tragend für die Aufrechterhaltung der Arrhythmie vermuteten sie multiple, sich dynamisch verteilende Wellenfronten, so genannte funktionelle Reentry-Kreisläufe. In einem Hundeherz-Modell konnte die Gruppe um Maurice Allessie in den 1970-er Jahren erstmals experimentell diese funktionellen Reentry-Kreisläufe nachweisen ${ }^{8}$. Im Widerspruch zu den theoretischen Vorhersagen fanden sich in den experimentellen Arbeiten aber eine deutlich geringere Anzahl gleichzeitig zirkulierender Wellenfronten 5; 8; 9 . Im Folgenden entstand daher das Konzept relativ stabiler so genannter „Anchor“-Reentry-Kreise, die sich im Wesentlichen am posterioren linken Vorhof um anatomischer Hindernisse (z.B. die Ostien der Pulmonalvenen) herausbilden, und von denen ausgehend der Rest der Vorhöfe irregulär erregt wird, was in der Gesamtheit im Oberflächen-EKG das chaotische Bild von Vorhofflimmern generiert 10; 11. Zusammenfassend deuten die Ergebnisse der experimentellen und klinischen Studien darauf hin, dass der posteriore linke Vorhof im Übergangsbereich der Einmündung der großen Pulmonalvenentrichter sowohl für die Initiierung als auch für die Aufrechterhaltung der Rhythmusstörung Vorhofflimmern von tragender Bedeutung ist. 


\subsection{Klinische Therapieansätze für Patienten mit Vorhofflimmern}

Die klinische Behandlung von Patienten mit Vorhofflimmern erfordert zwei grundsätzliche Therapieentscheidungen. Aufgrund des mit der Rhythmusstörung assoziierten thrombembolischen Risikos muss für den einzelnen Patienten geklärt werden ob die Indikation für eine orale Antikoagulation besteht. Große randomisierte Studien zur oralen Antikoagulation konnten eine Reduktion der Schlaganfallrate um $60 \%$ und eine Reduktion der Gesamtmortalität um 30\% nachweisen ${ }^{3}$. Die Therapie ist aber auch mit einer Rate an schweren Blutungen von ca 1,5\% pro Jahr assoziiert 4. Daher ist die Entscheidung zur Antikoagulation für den individuellen Patienten eine Abwägung des thrombembolischen Risikos gegenüber dem Blutungsrisiko. Die Schwierigkeit der Einschätzung des individuellen thrombembolischen Risikos liegt in dem häufigen Auftreten asymptomatischer Arrhythmieepisoden ${ }^{12}$. Aufgrund dessen ist die Entscheidung zur Antikoagulation unabhängig von Dauer und Symptomen der Rhythmusstörung, sondern sie basiert auf der Abschätzung klinischer Surrogatparameter (CHADS 2 score), die in großen Populationsstudien als thrombembolische Risikofaktoren identifiziert worden sind ${ }^{4}$.

Die zweite grundsätzliche Therapieentscheidung betrifft die Frage, ob das Vorhofflimmern belassen und lediglich die AV-Knoten Überleitung / ventrikuläre Frequenz reguliert werden soll (Frequenzkontrolle), oder ob versucht werden soll, den Sinusrhythmus wiederherzustellen und dauerhaft $\mathrm{zu}$ stabilisieren (Rhythmuskontrolle). Diese Frage ist bis heute nicht schlüssig geklärt. Größere Mortalitätsstudien haben Frequenzkontrolle mit medikamentöser Rhythmuskontrolle verglichen ${ }^{13 ;} 14$. Übereinstimmend zeigten Patienten im Arm der medikamentösen Rhythmuskontrolle keinen Mortalitätsvorteil gegenüber der Frequenzkontrolle, im 
Gegenteil tendenziell ließ sich eine, wenn auch statistisch nicht signifikante, Übersterblichkeit feststellen. Bei der Interpretation dieser Ergebnisse ist zu berücksichtigen, dass die medikamentöse antiarrhythmische Therapie einen rhythmuserhaltenden Therapieansatz mit bekannt eingeschränkter Effektivität und wesentlichen proarrhythmogenen Risiken darstellt ${ }^{12 ;}{ }^{15}$. Daher ist es nicht unwahrscheinlich, dass ein großer Teil der Patienten in den Gruppen der Rhythmuskontrolle weiter unter Vorhofflimmern litt und zusätzlichen proarrhythmogenen Risiken ausgesetzt war. Die nur eingeschränkte EKG-Nachsorge ohne engmaschige systematische Erfassung auch asymptomatischer Vorhofflimmerrezidive ermöglicht keine detaillierte Aufarbeitung dieser Fragestellung. Spätere Subgruppenanalysen, die einen klaren Überlebensvorteil bei Patienten herausarbeiteten, bei denen mit Antiarrhythmikum eine sichere Stabilisierung des Sinusrhythmus gelungen war, unterstützen diese Sichtweise, ebenso wie die Tatsache, dass die tendenzielle Übersterblichkeit in den Armen der Rhythmuskontrolle im Wesentlichen auf eine signifikant erhöhte Rate rhythmogener Todesfälle zurückzuführen war ${ }^{14 ;}{ }^{16}$. Aufgrund dieser Unklarheiten ist die Entscheidung zur Frequenz- oder Rhythmuskontrolle bis heute eine Entscheidung, die hauptsächlich durch die symptomatische Beeinträchtigung des Patienten unter der Arrhythmie bestimmt wird ${ }^{17}$. Mit der Entwicklung kurativer Therapieansätze, die in der Lage sind einen effektiven Rhythmuserhalt bei nur geringem Therapieassoziierten Risiko zu ermöglichen, wird sich die Frage nach der prognostischen Relevanz der Stabilisierung des Sinusrhythmus erneut stellen und in entsprechenden Studien untersucht werden. Die Katheterablation von Vorhofflimmern stellt einen solchen Therapieansatz dar, für den bereits jetzt bei Patienten mit Herzinsuffizienz erste Hinweise auf eine Verbesserung der Überlebensprognose vorliegen ${ }^{18}$. 


\subsection{Entwicklung kurativer Behandlungsverfahren}

\section{Chirurgische Ablationsverfahren}

Kardiochirurgische Therapiekonzepte waren die ersten Ansätze einer kurativen Behandlung von Vorhofflimmern. Ende der 1980-er Jahre entwickelte die Gruppe um Jimmy Cox aufbauend auf der multiplen Wellentheorie von Moe und Abildskov erstmalig ein chirurgisches Konzept (MAZE) zur kurativen rhythmuserhaltenden Therapie von Vorhofflimmem ${ }^{19}$. Mittels chirurgischer Inzisionen führten sie eine Kompartmentierung beider Vorhöfe herbei. Ziel war eine Vermeidung aller möglichen Makro-Reentry-Kreisläufe, eine Reduktion der elektrisch erregbaren Gewebsmasse zur Vermeidung zirkulierenden Wellenfronten aus Mikro-Reentry-Kreisläufen und eine Isolation des posterioren linken Vorhofes inklusive der Einmündungen der Pulmonalvenen. Aufgrund ihrer exzellenten Resultate wurde die MAZE-Operation als Goldstandard der chirurgischen Therapie des Vorhofflimmerns angesehen ${ }^{19}$. Aufgrund des erheblichen Aufwandes und der langen Prozedurzeiten fand die Operation aber außerhalb einiger hoch erfahrener Zentren keine weit verbreitete Anwendung.

Mit dem IRAAF-Therapiekonzept (Intraoperative Radiofrequency Ablation of Atrial Fibrillation) stellten Kottkamp, Hindricks und Mohr erstmalig eine chirurgische Behandlungsstrategie vor, die sich prinzipiell und wesentlich vom Cox-MAZE Ansatz unterschied. Mittels unipolarer Hochfrequenzstromablation wurde ein lineares Ablationskonzept umgesetzt, das ausgehend vom inferioren Mitralklappenring alle Pulmonalvenen sequentiell verband ohne diese zu isolieren, und das das linke Herzohr sowie den rechten Vorhof gänzlich unbehandelt ließ ${ }^{20}$. Die Behandlungsergebnisse waren sowohl bei Patienten mit paroxysmalem als auch bei 
Patienten mit persistierendem Vorhofflimmern sehr gut ${ }^{21 ; 22}$. Trotzdem wurde die IRAAF-Studie im Dezember 2001 wegen seltener aber schwerwiegender Komplikationen unterbrochen. Bei 4 von 387 Patienten trat einige Tage nach der Operation eine Perforation des Ösophagus als Folge der Hochfrequenzstromablation im linken Vorhof auf ${ }^{24 ; 2}$

Basierend auf diesen Erfahrungen haben alternative Energieformen den Eingang in die chirurgische Ablation von Vorhofflimmern gefunden. Heutige Ablationsverfahren verwenden Kälteenergie, bipolaren Hochfrequenzstrom sowie hochfokussierten Ultraschall 23; 24 . Die Linienkonzepte sind limitiert und beschränken sich im Wesentlichen auf eine Isolation der Pulmonalvenen bzw. des gesamten posterioren linken Vorhofes ${ }^{25}$. In der klinischen Routine wird die chirurgische Ablation von Vorhofflimmern heute insbesondere als Begleittherapie bei anderen kardiochirurgischen Eingriffen mit eingesetzt. Ihr Stellenwert bei der Behandlung von Patienten mit alleinigem Vorhofflimmern ist dagegen aufgrund der rasch fortschreitenden Entwicklung zunehmend effektiverer katheterinterventioneller Ablationsverfahren eher gering.

\section{Katheterinterventionelle Ablationsverfahren}

Die Entwicklung katheterinterventioneller Ablationsverfahren konvergierte aus zwei pathophysiologisch grundsätzlich verschiedenen Ansätzen heraus.

Basierend auf der Beschreibung von Vorhofflimmern induzierenden PulmonalvenenFoci führten Haissaguerre und Mitarbeiter katheterinterventionelle Mapping- und Ablationsverfahren ein, mit Hilfe derer diese Foci identifiziert und abladiert werden konnten ${ }^{26}$. Um eine möglichst vollständige Elimination aller möglichen 
Pulmonalvenen-Trigger zu erreichen setzte sich später eine systematische und vollständige elektrische Isolation aller vorhanden Pulmonalvenen, die so genannte segmentale Pulmonalvenen-Diskonnektion, durch ${ }^{27}$. Aus der heutigen Perspektive ist dieses Verfahren lediglich bei Patienten mit vorrangiger Triggeraktivität sowie klinisch seltenem und kurzem Vorhofflimmern ein erfolgversprechendes Therapiekonzept. Die Effektivität wird limitiert durch: 1) weiter bestehende Trigger und Substrat im großen unbehandelten Pulmonalvenentrichter; 2) die Erholung der Pulmonalvenenleitung; 3) Vorhofflimmer-Trigger außerhalb der Pulmonalvenen; und 4) eine fehlende Therapie des Arrhythmie-Substrates insbesondere bei Patienten mit persistierendem Vorhofflimmern

Mit dem Ziel der Behandlung der die Rhythmusstörung unterhaltenden stabilen und instabilen Reentry-Kreise entstanden Konzepte zur katheterinterventionellen Therapie des Vorhofflimmer-Substrates. Initial zielten diese auf eine katheterinterventionelle Umsetzung vormals chirurgischer Linienführungen. Prinzipiell gestaltete sich aber die Platzierung linearer Läsionen durch Aneinanderreihung einzelner Ablationspunkte am schlagenden Herzen als schwierig, was durch fehlende drei dimensionale Orientierung, fehlende Katheterstabilität und fehlende Transmuralität/Kontinuität der Ablationslinien bedingt war. Mit der Möglichkeit einer verbesserten dreidimensionalen intrakardialen Orientierung basierend auf der Anwendung des elektroanatatomischen Mapping-Systemes (CARTO) wurde die Platzierung langer linearer Läsionen auch im linken Vorhof technisch deutlich vereinfacht. Alleinige linksatriale Ablationsprozeduren zur katheterinterventionellen Substratmodifikation wurden in Folge beschrieben. So berichteten Pappone und Mitarbeiter über ein großes Patientenkollektiv mit paroxysmalem und 
persistierendem Vorhofflimmern, das mit linksatrialen zirkumferentiellen Ablationen um die einzelnen Pulmonalvenen-Mündungen behandelt worden war ${ }^{28 ; 29}$.

Vom pathophysiologischen Standpunkt erscheint eine kombinierte Behandlung der die Rhythmusstörung initiierenden Trigger und des die Rhythmusstörung unterhaltenden Substrates die höchste Aussicht auf einen langfristigen Therapieerfolg zu bieten. Die erwähnte gegenwärtig weit verbreitete Technik der zirkumferentiellen linksatrialen Pulmonalvenenablation bietet diese Möglichkeit, vorausgesetzt, die linksatrialen Ablationslinien um die großen PulmonalvenenTrichter sind frei von Leitungslücken und führen zu einer tatsächlichen elektrischen Isolation des gesamten Trichters. Dieses Ziel ist nach wie vor eine katheterinterventionelle Herausforderung. Technologische Entwicklungen zur Verbesserung von dreidimensionaler Orientierung sowie Katheterstabilität und Katheterkontakt sind daher nötig. Die abschließende Beurteilung der Wertigkeit solcher Entwicklungen erfordert eine genaue Analyse klinischer Erfolgsraten und möglicher Komplikationsrisiken. Dementsprechend gliedert sich die vorliegenden Habilitationsschrift in drei Schwerpunkte, die anhand der entsprechenden Originalpublikationen behandelt werden: 1) Etablierung neuer Methoden zur katheterinterventionellen Therapie von Vorhofflimmern; 2) Analyse und Vermeidung von Komplikationsrisiken; und 3) Rolle und Methodik einer objektiven Nachkontrolle. 


\section{Wissenschaftliche Hypothesen}

Aufgrund der stark ansteigenden Zahl an Patienten mit Vorhofflimmern werden sowohl aus medizinischer als auch sozial-ökonomischer Perspektive wirksame kurative Therapieansätze benötigt, die es ermöglichen innerhalb eines medizinischen Standardverfahrens mit ausgewogenem Nutzen/Risiko-Verhältnis einem großen Teil der betroffenen Patienten eine entsprechende Behandlung anbieten zu können.

Im Rahmen der Entwicklung und Etablierung derartiger Behandlungsverfahren wurden die folgenden wissenschaftlichen Hypothesen untersucht:

Dreidimensionale anatomische Orientierung in der invasiven Elektrophysiologie - Entwicklung Modell-gestützter Verfahren zur Therapie von Vorhofflimmern und Vorhofflattern

1. Wie akkurat ist die dreidimensionale anatomische Abbildung einer elektroanatomischen Rekonstruktion des linken Vorhofes und umgebender Strukturen im Vergleich zur realen Anatomie im multislice CT?

2. Entwicklung eines bildintegrierten Verfahrens der Katheterablation von Vorhofflimmern basierend auf einem dreidimensionalen anatomischen CTModell des linken Vorhofes

3. Entwicklung eines Verfahrens der farblichen Visualisierung atrialer MakroReentry-Tachykardien innerhalb des dreidimensionalen anatomischen CTModells. 
Einfluß von Katheterstabilität und Wandkontakt auf die Kontinuität linearer anatomischer Ablationslinien zur Therapie von Vorhofflimmern

4. Wie beeinflusst die Katheternavigation mittels steuerbarer Schleusensysteme Prozedur und Langzeitergebnis der Ablation von Vorhofflimmern im Vergleich zur herkömmlichen Navigationsverfahren?

5. Entwicklung eines Verfahrens zur Bestimmung des elektrischen Wandkontaktes basierend auf der Messung der lokalen Widerstände zwischen Katheter und Myokard.

Auftreten, Behandlung und Vermeidung typischer Komplikationen der Katheterablation von Vorhofflimmern

6. Mit welcher Häufigkeit sind typische Ablationskomplikationen in einer großen klinischen Patientenkohorte zu beobachten?

7. Wie sollten Ösophagusperforationen diagnostiziert und behandelt werden?

8. Entwicklung eines Verfahrens zur intraprozeduralen dreidimensionalen Visualisierung der anatomischen Beziehung zwischen Ösophagus, linkem Vorhof und geplanten Ablationslinien. 
Einfluss der Variabilität der Vorhofflimmerwahrnehmung auf Strategien der Rhythmusüberwachung vor und nach Vorhofflimmerablation

9. Wie akkurat ist die individuelle Wahrnehmung von Vorhofflimmern bei hochsymptomatischen Patienten vor und nach Katheterablation?

10. Wie beeinflusst die Dauer der Rhythmusüberwachung die Anzahl an Patienten, bei denen Vorhofflimmern detektiert wird?

11. Wie beeinflusst die Art der Rhythmusüberwachung die Anzahl an Patienten, bei denen Vorhofflimmern detektiert wird? 


\section{Einführung in die durchgeführten wissenschaftlichen Untersuchungen}

\subsection{Technologische Entwicklungen zur Katheterablation von Vorhofflimmern}

\subsubsection{Dreidimensionale anatomische Orientierung}

\section{Prinzipien und Genauigkeit der intrakardialen 3D-Orientierung}

Die Anforderungen an katheterinterventionelle Therapien komplexer Rhythmusstörungen, insbesondere von Vorhofflimmern, führten zur Entwicklung von Systemen die eine nicht-fluoroskopische intrakardiale 3D Orientierung ermöglichten. Diesbezüglich wurde 1996 das Prinzip des CARTO Systems beschrieben, bei dem die 3D Lokalisation eines speziellen Sensor-tragenden Ablationskatheters innerhalb eines lokalen um den Brustkorb des Patienten generierten elektromagnetischen Feldes realisiert wurde ${ }^{30}$. Aufbauend auf einem anderen technologischen Ansatz erfolgte mit dem NavX-EnSite System 1999 die Beschreibung des Prinzips der 3D Lokalisation intrakardialer Elektrodenkatheter durch transthorakale Applikation und Ableitung geringer elektrischer Ströme ${ }^{31}$. In der klinischen Anwendung zielten beide Systeme darauf ab eine virtuelle 3D Anatomie des linken Vorhofes zu rekonstruieren, die als Arbeitsgrundlage für die Platzierung der Ablationslinien dienen konnte. Diese Rekonstruktionen basierten auf dem manuellen Abtasten der inneren Oberfläche des linken Vorhofes mittels Ablationskatheter. Fehlende Oberflächenpunkte wurden nach speziellen Softwarealgorithmen interpoliert.

Die Frage nach der Genauigkeit der rekonstruierten Anatomie des linken Vorhofes wurde im Vergleich zur 3D Anatomie bildgebender Verfahren wie der MehrschichtComputertomographie untersucht $(n=100)$. Es zeigte sich, dass elektroanatomische Rekonstruktionen erfahrener Elektrophysiologen die Anatomie des linken Vorhofes in 
den für die Katheterablation von Vorhofflimmern relevanten Bereichen mit guter Präzision abbilden konnten. Insbesondere zeigte sich eine reale Darstellung der Anatomie und der Abstandsparameter um die linken Pulmonalvenen, um den Mitralannulus und zur Hinterwand des linken Vorhofes. Darüber hinaus wurden aber auch die Grenzen und Limitationen einer rekonstruierten Vorhofanatomie deutlich. So zeigte sich eine systematische Unterschätzung der Diameter um die rechten Pulmonalvenenostien. Da die Genauigkeit der anatomischen Rekonstruktion wesentlich vom Katheterzugang und der manuellen Erreichbarkeit der Oberfläche abhängig ist, sind die systematischen Abweichungen an den rechten Pulmonalvenen mit hoher Wahrscheinlichkeit durch eingeschränkte Freiheiten der Kathetersteuerung am Ort der transseptalen Punktion bedingt. Eine ähnliche Einschränkung ist als ursächlich für die beobachteten Ungenauigkeiten der Rekonstruktion der Gewebebrücke zwischen linkem Vorhofohr und linker oberer Pulmonalvene anzunehmen.

\section{Bildintegration und Modell-basierte Therapie von Vorhofflimmern}

Mit der Etablierung anatomisch definierter Linienkonzepte um die Ostien der Pulmonalvenen rücken das Verständnis und die Berücksichtigung der individuellen anatomischen Gegebenheiten in das Zentrum einer erfolgreichen Katheterablation von Vorhofflimmern. Vor dem Hintergrund einer hohen inter-individuellen Variabilität der Vorhof- und Pulmonalvenen-Anatomie sind daher die Grenzen der Auflösung und der Genauigkeit der anatomischen Rekonstruktion eine Limitierung, die weitere Entwicklungen zur 3D Orientierung nötig macht.

Die Bildintegration ist ein Konzept, das seit geraumer Zeit in anderen medizinischen Fachdisziplinen eingesetzt wird, um die Präzision dreidimensionaler Eingriffe durch 
Visualisierung der realen 3D Anatomie zu verbessern. So konnte die Integration vormalig aufgezeichneter CT/MR Bilder in peri-prozedurale in-vivo Abbildungen die Sicherheit und Effektivität neurochirurgischer Prozeduren erhöhen ${ }^{32}$.

Bildintegrierte medizinische Prozesse setzen sich aus zwei Hauptkomponenten zusammen. Der erste Schritt ist die Schnittbild-Erzeugung und die dreidimensionale Rekonstruktion des Zielorganes aus dem Rohdatensatz (Segmentierung). Der zweite Schritt ist die Ausrichtung des anatomischen Bildes entsprechend der tatsächlichen 3D Position im Operationsfeld (Registrierung).

Bezogen auf den kardiologischen/elektrophysiologischen Einsatz der Bildintegration hat sich die kardiale Bildgebung mittels Computertomographie oder Magnetresonanztomographie standardmäßig etabliert. Die Registrierung des 3D Bildes ist aber gegenüber anderen medizinischen Fachdisziplinen aufgrund von kardialer Mobilität und Atemschwankungen deutlich erschwert. Vor diesem Hintergrund verwendeten die ersten Ansätze der Bildintegration bei Vorhofflimmerablation das 3D-Bild nur als Zusatzinformation zur virtuellen Vorhofrekonstruktion, ohne klar definierte Registrierungsstandards, und mit variablem klinischen Erfolg ${ }^{33 ; 34}$.

Mit dem Ziel einer vollständig Modell-basierten Ablationstherapie wurde von uns ein neuartiger Registrierungs-Algorithmus entwickelt und validiert. Die Grundlage dieser Registrierung basiert auf der Kennzeichnung der Pulmonalvenen-Anatomien als Registrierungsmarker im NavX-EnSite System. Die Pulmonalvenen sind als kardiale Strukturen im posterioren Mediastinum fixiert und unterliegen nahezu keiner kardialen Mobilität. Über den Herzzyklus verändern sie lediglich ihre Form, aber nicht ihre dreidimensionale Orientierung. Mit Hilfe eines zirkulären multipolaren Mapping- 
Katheters kann jede Pulmonalvene als eigenständige Anatomie markiert werden. Daraus resultieren vier anatomische Strukturen mit individueller Ausrichtung im dreidimensionalen Raum. Vergleichbar einem Schlüssel-Schloss-Prinzip wird das 3D-Bild des linken Vorhofes in diese Pulmonalvenen-Anatomie eingepasst. Wenige zusätzliche katheterinterventionell typisch zu identifizierende Orientierungspunkte im linken Vorhof (z.B. wenn der Katheter über die untere Kante der linken unteren Pulmonalvene in den linken Vorhof fällt) wurden zur Feinjustierung des Registrierungsprozesses genutzt. Anschließend erfolgte die vollständige Orientierung, Planung und Platzierung der Ablationslinien innerhalb des 3D-Modelles der Vorhofanatomie. Atem-bedingte Schwankungen der Katheter-Positionen im statischen Vorhof-Modell wurden über einen Kompensations-Algorithmus ausgeglichen, der auf der Analyse der Thorax-Impedanzen im Atemzyklus basiert.

Im Rahmen der Validierung des Registrierungsprozesses wurden 31 Kontroll-Punkte im linken Vorhof und den Pulmonalvenen definiert, die der Elektrophysiologe mit dem Katheter auf konservative Art und Weise entsprechend Fluoroskopie, Elektrogram und taktilem Katheter-Feedback erreichen musste. Anschließend wurde die Katheterposition im integrierten 3D Bild bestimmt und verglichen.

Es konnte gezeigt werden, dass diese Form einer standardisierten Pulmonalvenenbasierten Registrierung des CT-Bildes in der Lage ist, ein reales 3D-Modell des linken Vorhofes als Arbeitsgrundlage für eine Vorhofflimmerablation zu schaffen. Die Registrierung war insbesondere akkurat im Bereich der Zielareale der Vorhofflimmerablation am posterioren linken Vorhof und um die Pulmonalvenenostien. Ungenauigkeiten der Registrierung zeigten sich im Bereich des Vorhofseptums und der Mitralklappe. Dieses Ergebnis unterstützt frühere 
Beobachtungen, denen zufolge der posteriore Vorhof und die Pulmonalvenen am wenigsten von Mobilität im Rahmen des kardialen Zyklus betroffen sind, wogegen Septum und Mitralklappe Verschiebungen unterliegen.

Klinisch konnte mit diesem Modell-basierten Ansatz einer Vorhofflimmerablation bei über $90 \%$ aller behandelten 54 Patienten eine vollständige Isolation aller Pulmonalvenen erzielt werden. In der Nachkontrolle waren 46/54 (85\%) Patienten frei von Rezidiven ihrer Rhythmusstörung.

\section{D-Visualisierung intrakardialer elektrischer Informationen}

Neben der korrekten Platzierung anatomischer determinierter Ablationslinien (z.B. im Rahmen der zirkumferentiellen Pulmonalvenenablation) ist das Verständnis der dreidimensionalen intrakardialen Erregungsausbreitung wichtig für die erfolgreiche Behandlung von Patienten mit Vorhofflimmern und entsprechenden Folgearrhythmien. Abhängig vom Kollektiv und der Art der initialen Vorhofflimmerablation wird im Anschluss das Auftreten atrialer Makro-ReentryTachykardien in $15-30 \%$ der Patienten beobachtet ${ }^{35 ; 36}$. Hierbei handelt es sich um Arrythmien, die häufig aber nicht ausschließlich als stabile Erregungskreise durch Lücken vormaliger Ablationslinien entstehen. Durch ihre klinische Stabilität und eine häufig tachykarde 2:1 Überleitung auf die Herzkammern sind diese Rhythmusstörungen häufig sehr symptomatisch und können nicht selten zu einer Tachykardiomyopathie führen. Antiarrhythmische Therapieversuche haben nur eine eingeschränkte Wirksamkeit. Eine erfolgreiche katheterinterventionelle Therapie setzt ein detailliertes Verständnis des dreidimensionalen Verlaufes des ReentryKreises innerhalb der Vorhofanatomie voraus, um ein adäquate Ablationslinie planen und platzieren zu können. 
Die beschriebenen dreidimensionalen Mapping-Systeme erlauben eine Beurteilung der intrakardialen elektrischen Erregungsausbreitung durch die kombinierte Darstellung einer dreidimensionalen intrakardialen Lokalisation zusammen mit einer farblichen Kodierung der dort gemessenen lokalen Aktivierungszeit in Bezug auf ein stabiles Referenzsignal (Aktivierungsmapping). Dieser Ansatz gilt als Standard zur Beurteilung intrakardialer Erregungsausbreitung ${ }^{35}$. Bei Patienten mit Makro-ReentryTachykardien nach Vorhofflimmerablationen ist er aber limitiert durch eine Vielzahl diskontinuierlicher Narben mit entsprechend langsamen Leitungsarealen, die nicht Teil des Reentry-Kreises sind, aber nicht als solche identifiziert werden können. Das Beeinträchtigt das Verständnis der Rhythmusstörung und den Erfolg der Ablation.

Aufbauend auf dem oben geschilderten Prinzip eines vollständig Bild-integrierten Therapieansatzes haben wir ein Verfahren entwickelt, mit dem der Reentry-Kreis innerhalb der realen Anatomie des linken Vorhofes direkt visualisiert werden kann. Dieser Ansatz basiert auf einer dreidimensionalen farblichen Kodierung so genannter Entrainment Informationen. Entrainment Manöver sind elektrophysiologische Stimulationsmanöver, die von der Spitze des Ablationskatheters aus durchgeführt werden. Ziel ist es, die Tachykardie ,einzufangen'. Nach Stimulationsende wird die Zeit bis zum Wiedereintreten des klinischen Reentry-Mechanismus erfasst (ReturnZyklus). Ist diese Zeit sehr kurz, befindet sich der Katheter in der Nähe des ReentryKreises, ist sie dagegen sehr lang befindet er sich weit vom Reentry-Kreis entfernt. Die farbliche Kodierung dieses Return-Zyklus ermöglicht daher eine dreidimensionale Beschreibung der lokalen Distanz zum Reentry-Kreis und letzten Endes des Reentry-Kreises selber. Wird diese Methode in einem vorher integrierten 3D-Modell der Vorhofanatomie durchgeführt, lässt sich anschaulich der Verlauf der 
Rhythmusstörung darstellen und eine Ablationslinie planen, mit der die Rhythmusstörung erfolgreich unterbrochen werden kann.

Das Verfahren wurde bei 26 Patienten validiert. Insgesamt wurden 39 Reentry-Kreise untersucht, dargestellt und erfolgreich abladiert. Die Ergebnisse unterstreichen, dass ein einzelner Patient häufig mehrere Formen einer Makro-Reentry-Tachykardie ausbilden kann, die klinische Relevanz haben, aber im Oberflächen-EKG nicht immer zu unterscheiden sind. Eine Analyse der Reentry-Kreise zeigte, dass lediglich 56\% der Tachykardien durch Lücken vormaliger Ablationslinien entstanden waren. Die übrigen Kreise hatten sich infolge Fibrosierungen als gegenüber dem Vorhofflimmern alternative Manifestationsform der atrialen Grunderkrankung etabliert. Unter Einsatz der beschriebenen Technik waren am Ende der Prozedur alle Patienten nicht induzierbar, dass heißt auch mit aggressiver Stimulation waren keine weiteren Makro-Reentry-Tachykardien auslösbar. Der klinische Langzeitverlauf dieser Patienten mit therapeutisch anspruchsvollen Rhythmusstörungen war exzellent.

\subsubsection{Stabilität und Kontakt des Katheterzuganges}

\section{Methoden zur Stabilisierung des Katheterzuganges}

Neben dem Verständnis der indivduellen anatomischen Gegebenheiten erfordern die aktuellen Konzepte der katheterinterventionellen Behandlung von Vorhofflimmern die Möglichkeit der Platzierung langer kontinuierlicher und transmuraler Ablationslinien in allen Zielbereichen des Vorhofes. Die Aneinanderreihung fokaler Ablationsläsionen zu einer lückenfreien kontinuierlichen Linie ist durch das schlagende Herz und den atmenden Patienten infolge Instabilität des Ablationskatheters erschwert. 
Entsprechend wurden technische Entwicklungen zur verbesserten Stabilisierung des Katheterzuganges eingeführt.

Diese Entwicklungen führten einerseits zu Roboter-assistierten Steuerungen. Hierbei ist das Stereotaxis System zu erwähnen, bei dem die Katheter-Steuerung durch von außen einwirkende in ihrer Orientierung variable permanente Elektromagnete realisiert wird $37 ; 38$. Ein anderes Roboter-gestütztes System nutzt die Manövrierbarkeit steuerbarer Schleusen im linken Vorhof ${ }^{39}$.

Manuell kontrollierte steuerbare Schleusen stellen einen weiteren Ansatz zur Verbesserung von Katheterzugang und Katheterstabilität dar. $\mathrm{Da}$ der katheterinterventionelle Zugang in den linken Vorhof ohnehin den Einsatz langer Schleusensysteme nötig macht, handelt es sich hierbei im Gegensatz zu den oben genannten Entwicklungen um eine relativ einfache Verbesserung ohne technische Laborinvestitionen und mit dem Vorteil, dass dem behandelnden Elektrophysiologen die taktilen Informationen vom Ablationskatheter erhalten bleiben.

In einer Fall-Kontroll-Studie haben wir den Einsatz einer manuell steuerbaren Schleuse im Vergleich zu einem konventionellen Ablationszugang an 166 Patienten untersucht. Bei gleichen Prozedurzeiten erhöhte sich die Rate an Patienten, bei denen eine vollständige Isolation aller Pulmonalvenen erreicht werden konnte von 10\% auf $52 \%$. Dafür wurde signifikant weniger Hochfrequenzenergie benötigt, was einen besseren Energietransfer ins Myokard nahelegt. Im klinischen Verlauf stieg die Erfolgsrate (Freiheit von Vorhofflimmern und atrialen Makro-Reentry-Tachykardien) nach einmaliger Prozedur von 56\% auf $77 \%$. Aktuell werden diese Ergebnisse in einer prospektiven randomisierten multizentrischen Studie überprüft. 
Aus klinischer Sicht zeigt sich der Vorteil manuell steuerbarer Schleusentechnologien vor allem an für den stabilen Katheterzugang typischerweise schwierig zu erreichenden Prädilektionsstellen; wie z.B. an der anteriore Kante der linken Pulmonalvenentrichter, an der Gewebebrücke zwischen linkem Herzohr und linker oberer Pulmonalvene, und unterhalb der rechten unteren Pulmonalvene.

\section{Bestimmung des Wandkontaktes bei Hochfrequenzstromablation}

Einen stabilen Katheterzugang vorausgesetzt ist der Kontakt zwischen Ablationselektrode und Gewebe der nächste kritische Parameter, der die Effektivität, Transmuralität und auch die Sicherheit einer Hochfrequenzstromablation beeinflusst. Zu geringer Wandkontakt führt zu ineffektiven Läsionen. Zu hoher Wandkontakt kann einen unkontrolliert überschießenden Energietransfer in das Myokard verursachen, was zu Überhitzungen mit Verkochungsreaktionen und anschließenden Perforationen/Tamponaden führen kann. Bisher beruht die Einschätzung des Gewebekontaktes auf einer Erfahrungs-basierten Mischung aus fluoroskopischer Information, Elektrogramqualitäten und taktilem Katheter-Gefühl.

Von technischer Seite kann der Katheter-Gewebe-Kontakt auf zwei Arten objektiviert werden. Ein Ansatz besteht in der Messung des mechanischen Kontaktdruckes zwischen Katheter und Gewebe mittels spezieller Drucksensoren. Obwohl vielversprechend, ist diese Methode teilweise abhängig von der Orientierung der Katheterspitze und ermöglicht zudem keine Aussage über die Menge an Energie, die während einer Ablation ins Gewebe transportiert wird.

Ein zweiter Ansatz zur Objektivierung des Katheter-Gewebe-Kontaktes ist die Messung der elektrischen Ankopplung der Spitze des Ablationskatheters an das 
Myokard. Diese Methode basiert auf der Messung der lokalen kapazitiven und resistiven Widerstände zwischen dem Katheter und dem Myokard. Die genaue Bestimmung dieser Widerstände wird durch einen 3-endigen elektrischen Stromkreis realisiert, bei dem der Katheter einen Pol und zwei weit von einander entfernte Hautpatch-Elektroden die anderen Pole darstellen. Wird ein Strom vom Katheter zu einer Hautpatch-Elektrode durch geleitet, dann entwickelt dieser Stromkreis die Eigenschaft, dass die Spannungsmessung an der zweiten Hautpatch-Elektrode genau der Spannung am gemeinsamen Kreuzungspunkt (im Myokard) gleicht. Durch die Kenntnis von Stromstärke und Spannung im Katheter/Myokard können die lokalen Widerstände ermittelt und auf dem Ablationskatheter als Kopplungsindex visualisiert werden. Dieses Verfahren ist unabhängig von der Orientierung der Katheterspitze.

In einer ersten Validierungsstudie im Menschen haben wir den elektrischen Kontaktindikator bei 12 Patienten mit Vorhofflimmerablation eingesetzt und gegen herkömmliche Methoden der Kontaktanalyse getestet. In der geblindeten Untersuchung war der Indikator in der Lage mit 97\% Sensitivität und 95\% Spezifität elektrischen Gewebekontakt vorherzusagen, und verschiedene Kontaktgraduierungen zu differenzieren. Für zukünftige Entwicklungen sind Veränderungen dieses Parameters während Hochfrequenzablation interessant, da sie prinzipiell das Potential haben, die Effektivität der Ablationsläsionsbildung zu beschreiben, und damit die Menge an benötigter Energie lokal zu titrieren. 


\subsection{Komplikationsrisiken der Katheterablation von Vorhofflimmern}

\section{Komplikationen der Vorhofflimmerablation in einer großen klinischen Kohorte}

Die Katheterablation von Vorhofflimmern stellt als potentiell kuratives Therapieverfahren einen Durchbruch für die Behandlung betroffener Patienten dar. Trotzdem treten bei diesen Eingriffen häufigere und schwerere Komplikationen auf, als sie bei herkömmlichen Ablationen einfacher Arrhythmien zu beobachten sind. $\mathrm{Da}$ der Wert einer Therapie sich an dem Verhältnis von Nutzen und Risiko und der Verfügbarkeit anderer Therapiealternativen bemisst, ist eine detaillierte Analyse von Art und Häufigkeit der im klinischen Alltag tatsächlich auftretenden Komplikationen nötig. Wissenschaftliche Daten zu diesem Thema sind inkonsistent. Große Ablationszentren berichteten sehr niedrige Komplikationsraten, wohingegen eine weltweite Befragung innerhalb der ersten Jahre der Vorhofflimmerablation eine Rate an schweren Komplikationen von $6 \%$ berichtete $40 ; 41 ; 42$. Jüngere Daten eines multizentrischen Registers zeigten niedrigere aber dennoch beachtenswerte Komplikationsraten von $3.9 \%{ }^{43}$. Kontrovers diskutiert werden auch potentielle Risikofaktoren für Ablationskomplikationen 43; 44; 45 .

Im Rahmen einer monozentrischen Studie berichteten wir die Rate an schweren Ablations-bedingten Komplikationen nach zirkumferentieller Pulmonalvenenablation in einer großen klinischen Patientenkohorte von 1000 Patienten, die zu 100\% im Rahmen der Nachbeobachtung nachverfolgt wurden. Es wurden alle Patienten in diese Studie eingeschlossen, die zwischen Oktober 2005 und Januar 2008 in unserem Zentrum eine Vorhofflimmerablation erhalten hatten. 
Insgesamt zeigten sich vergleichbar mit den jüngeren Registerdaten 39 (3,9\%) schwere Komplikationen. Die häufigsten schweren Komplikationen waren Tamponaden $(1,3 \%)$ die nahezu ausschließlich durch Perikardpunktion therapiert werden konnten. Lediglich zwei Patienten $(0,2 \%)$ bedurften eines kardiochirurgischen Eingriffes. Alle Patienten mit Tamponaden hatten einen unauffälligen weiteren klinischen Verlauf ohne Langzeitschäden. Die zweithäufigste Gruppe waren vaskuläre Komplikationen $(1,1 \%)$ an den femoralen Punktionsstellen, die ebenfalls nahezu ausschließlich konservativ bzw. mit Thrombin-Injektion behandelt werden konnten. Thrombembolische Komplikationen $(0,4 \%)$ wurden in Form von drei Schlaganfällen und einer TIA beobachtet. Drei der vier thrombembolischen Komplikationen traten innerhalb von 24 Stunden nach Ablation auf. Eine Pulmonalvenenstenose als früher typische Komplikationen der Vorhofflimmerablation wurde lediglich bei einem Patienten $(0,1 \%)$ beobachtet. Zwei Patienten $(0,2 \%)$ zeigten eine Endokarditis an der Mitralklappe bzw. am Eingang zum linken Herzohr, die jeweils medikamentös behandelt werden konnte. Bei zwei Patienten $(0,2 \%)$ kam es zu einer Sedierungs-assoziierten Aspiration (0,2\%), die in einem Fall eine Aspirationspneumonie verursachte und antibiotisch behandelt werden musste.

Innerhalb der Studie wurden zwei Todesfälle $(0,2 \%)$ innerhalb von 4 Wochen nach Ablation beobachtet. Ein Patient erlitt 14 Tage nach Ablation einen nächtlichen plötzlichen Herztod aus dem Wohlbefinden heraus. Bei normaler linksventrikulärer Pumpfunktion ohne linksventrikuläre Hypertrophie, bei fehlender antiarrhythmischer Medikation und bei unauffälligem postinterventionellen LzEKG (insbesondere ohne Hinweise für Bradykardien, ventrikuläre Tachykardien oder Zeichen vagaler Denervierung) bleibt die Ursache dieses Todesfalles ungeklärt. Einer Obduktion 
stimmte die Familie nicht zu. Der zweite Patient verstarb 4 Wochen nach Ablation in einem auswärtigen Krankenhaus. Er litt an einer dilatativen Kardiomyopathie mit deutlich eingeschränkter linksventrikulärer Funktion. Die klinischen Unterlagen des auswärtigen Krankenhaus mit Dokumentation von Mediastinitis, Schlaganfällen und septischen Krankheitsbild lassen das Vorliegen einer nicht diagnostizierten atrioösophagealen Fistel als hoch wahrscheinlich erscheinen.

Die Ösophagusperforation mit Entwicklung einer atrio-ösophagealen Fistel stellt eine der seltenen wenngleich gefährlichsten Komplikationen der Ablation von Vorhofflimmern dar. Neben dem oben erwähnten Fall wurde die Komplikation bei 2 weiteren Patienten beobachtet, diagnostiziert und behandelt, so das sich trotz Vorsichtsmaßnahmen eine Gesamtinzidenz von $0,3 \%$ ergibt. Diese Rate ist höher als in der Literatur beschrieben, wobei zu berücksichtigen ist, das das klinisch verzögerte Auftreten der komplexer Symptome einige Wochen nach Ablation dazu führt, dass die Komplikation häufig nicht erkannt wird. Verlässliche Daten fehlen daher in der Literatur. Von klinischer Seite hat das Nicht-Erkennen einer Ösophagusperforation katastrophale Folgen, weil die Komplikation ohne zeitnahe Therapie bei nahezu allen Patienten tödlich verläuft.

Zusammenfassend macht die Studie deutlich, dass selbst in einem erfahrenen Zentrum die Vorhofflimmerablation ein wesentliches Risiko schwerer Komplikationen mit sich bringt. Patientenalter über 75 Jahren und klinische Herzinsuffizienz waren unabhängige Prädiktoren für erhöhte Komplikationsraten. Wichtig ist, dass die Komplikationen zeitnah erkannt und entsprechend behandelt werden. Das führte in unserer Studie dazu, dass 34 der 39 Patienten mit schweren Komplikationen keine langzeitigen Folgeschäden davon trugen. 


\section{Diagnose und Behandlung der Ösophagusperforation}

Mit der Entwicklung kurativer Behandlungsverfahren zur Therapie von Vorhofflimmern entstand durch die Komplikation der Ösophagusverletzung ein bis dahin unbekanntes Krankheitsbild, die atrio-ösophageale Fistel. Diese wurde erstmalig nach chirurgischen Ablationsverfahren beschrieben ${ }^{46}$. Später wurden Ösophagusperforationen auch nach katheterinterventionellen Ablationsverfahren berichtet ${ }^{47}$. Das verzögerte Auftreten dieser Komplikation mehrere Tage bis Wochen nach Ablationsbehandlung zusammen mit einem komplexen klinischen Erscheinungsbild sind mit hoher Wahrscheinlichkeit dafür verantwortlich, das die Komplikation zu selten erkannt, in der Literatur beschrieben und angemessen behandelt wurde. Die hohe assoziierte Sterblichkeit macht eine exakte Diagnosestellung und Therapie klinisch höchst relevant.

Wir haben daher in einem Kollektiv von 4 Patienten mit Ösophagusperforationen (3 nach chirurgischer Ablation, 1 nach Katheterablation) die klinischen Symptome, Laborparameter, diagnostischen Verfahren und Behandlungsansätze aufgearbeitet, um Richtlinien für das Management dieser Patienten ableiten zu können.

Als klinische Leitsymptome zeigten sich Fieber, Leukozytose und retrosternale Schmerzen 8 bis 28 Tage nach Ablation. Diese Symptome sind mit hoher Wahrscheinlichkeit durch die infolge der atrio-ösophagealen Fistel entstandene bakterielle Mediastinitis verursacht. Dicht gefolgt auf diese Initialsymptome traten innerhalb von 5 bis 40 Stunden neurologische Symptome, häufig als TIA, in Erscheinung, die auf rezidivierende Luftembolien zurückzuführen sind. Gastroskopische und transösophageale Untersuchungen verbieten sich aufgrund der Gefahr weiterer Luftembolien. Die Diagnose muss im Thorax-CT nach oraler 
Aufnahme von wasserlöslichem Kontrastmittel gestellt werden. Alle Patienten zeigten typische CT-Befunde mit freier Luft im Mediastinum hinter dem posterioren linken Vorhof und mit Kontrastmittelaustritten in das hintere Mediastinum. Nach Diagnosestellung muss umgehend eine chirurgische Therapie erfolgen. Zeitliche Verzögerungen waren mit einer dramatischen Zunahme neurologischer Komplikationen assoziiert.

Die Therapie der Wahl ist eine vollständige Resektion des betroffenen ÖsophagusAbschnittes. Eine Übernähung führte zum Wiederauftreten der Fistel und zur Entwicklung weiterer Fistelgänge in das bronchopulmonale System. Das beste Ergebnis zeigten Patienten, bei denen der betroffene Ösophagus-Abschnitt reseziert und blind verschlossen worden war. In einem zweizeitigen Eingriff wurde bei diesen Patienten nach Abheilung der Mediastinitis der obere Gastrointestinaltrakt reanastomosiert, ggf. über einen Magenhochzug.

\section{Intraprozedurale Visualisierung des Ösophagus}

Die Gefahr der Ösophagusperforation führte zu einem starken wissenschaftlichen und klinischen Interesse an den anatomischen Beziehungen zwischen Ösophagus und linken Vorhof mit der Identifizierung kritischer Ablationsareale.

Vor diesem Hintergrund führten wir die Methode der dreidimensionalen Darstellung des Ösophagus-Verlaufes innerhalb non-fluoroskopischer Mapping-Systeme ein. Dafür wurde ein Sensor-tragender CARTO-Katheter über die Speiseröhre in den sedierten Patienten eingebracht, mit dessen Hilfe der Verlauf des Ösophagus markiert und zusammen mit der rekonstruierten Anatomie des linken Vorhofes dreidimensional dargestellt werden konnte. Bei 30 Patienten wurden der Verlauf des 
Ösophagus hinter dem linken Vorhof und der Kontakt des Ösophagus zum linken Vorhof in-vivo analysiert. Zur Datenerfassung wurde der posteriore linke Vorhof in 25 Felder unterteilt, in denen für jeden Patienten Verlauf und Kontakt erfasst werden konnten. Es zeigte sich, dass die anatomische Beziehung von Ösophagus zu linkem Vorhof einer erheblichen inter-individuellen Schwankung unterliegt. Für den einzelnen Patienten fanden wir aber eine stabile Lage des Ösophagus, die über die gesamte Prozedur erhalten blieb und sich auch bei Re-Ablationen identisch abbildete. Die häufigsten Areale mit direktem Kontakt zwischen linkem Vorhof und Ösophagus fanden sich am inferioren-posterioren linken Vorhof und hier insbesondere auf der Seite der linken Pulmonalvenenostien. In 57\% der Patienten lagen die posterioren Anteile einer der beiden zirkumferentiellen Ablationslinien innerhalb von Kontaktarealen mit dem Ösophagus.

In der Folge entwickelte sich die Darstellung des Ösophagus innerhalb dreidimensionaler Mapping-Systeme zu einem Standardverfahren der periprozeduralen Visualisierung der anatomischen Beziehungen zwischen Ösophagus und linkem Vorhof mit entsprechender Anpassung der Ablationslinienführung und Reduktion der Ablationsenergie in kritischen Kontaktarealen.

Einschränkend bleibt festzustellen, dass trotz dieser Vorsichtsmaßnahmen weitere Ösophagusperforationen aufgetreten sind. Daher werden gegenwärtig aufbauend auf der beschriebenen Visualisierung zusätzliche Methoden zur Protektion des Ösophagus entwickelt und validiert. Hier ist insbesondere die intraösophageale Temperaturmessung zu erwähnen, die neben den anatomischen Informationen über gefährdete Ablationsareale zusätzliche funktionelle Informationen über den tatsächlich auftretenden Energietransfer in den Ösophagus vermittelt. 


\subsection{Rhythmusmonitoring und Erfolgskontrolle nach Ablation}

\section{Perzeption von Vorhofflimmern vor und nach Katheterablation}

Die wissenschaftliche und klinische Beurteilung von Effektivität und Erfolgsraten kurativer Therapieverfahren zur Behandlung von Patienten mit Vorhofflimmern erfordert eine objektive Erfassung potentiell auftretender Arrhythmierezidive. Vom Gesichtspunkt der Nachkontrolle unterscheiden sich Vorhofflimmerpatienten damit wesentlich von Patienten die an anderen Rhythmusstörungen leiden. Für die Behandlung konventioneller Arrhythmien wie AV-Knoten-Reentry-Tachykardien und AV-Reentry-Tachykardien gilt die Freiheit von symptomatischen Rezidiven der Rhythmusstörung als ausreichender Surrogat-Parameter für Ablationserfolg, da die Symptome der Rhythmusstörung relativ zuverlässig deren Wiederauftreten anzeigen. Demgegenüber weist die subjektive Wahrnehmung von Vorhofflimmern deutliche interindividuelle Variationen auf, und das asymptomatische Auftreten der Rhythmusstörung ist ein bekanntes Phänomen 48; 49. Patienten, die eine Vorhofflimmerablation erhalten, stellen jedoch ein hoch selektiertes Kollektiv dar, das in der Regel durch einen hohen Leidensdruck gekennzeichnet ist. Aufgrund dieser Charakteristika wurde auch für Patienten mit Vorhofflimmerablation die Freiheit von Symptomen lange Zeit als Äquivalent einer Freiheit von tatsächlichen Arrhythmierezidiven und einer damit erfolgreichen Ablation gewertet.

In einer prospektiven Studie analysierten wir die Wahrnehmung von Vorhofflimmern in einem hoch symptomatischen Patientenkollektiv vor und nach einer katheterinterventionellen Ablation. Bei 114 Patienten erfolgte dafür die Aufzeichnung eines 7-Tage-LzEKG vor und unmittelbar nach Ablation sowie nach 3, 6 und 12 Monaten. Während des 7-Tage-LzEKG führten die Patienten ein engmaschiges 
Symptom-Tagebuch, in dem sie stündlich Art und Dauer subjektiv empfundenen Arrhythmieepsioden dokumentierten. Nach Auswertung des 7-Tage-LzEKG erfolgte eine Korrelation zwischen Symptomen und objektiv dokumentierten Arrhythmieereignissen.

Vor Ablation konnten bei mehr als $50 \%$ dieser an sich hochsymptomatischem Patienten auch asymptomatische Arrhythmieepisoden nachgewiesen werden. Bei $5 \%$ der Patienten fand sich im 7-Tage-LzEKG vor Ablation nur asymptomatisches Vorhofflimmern trotz früherer dokumentierter symptomatischer Episoden. Der Anteil vollständig asymptomatischer Patienten stieg nach Ablation signifikant an: Nach 3, 6, und 12 Monaten fand sich bei 38\%, 37\% und 36\% der Patienten mit Arrhythmierezidiven komplett asymptomatisches Vorhofflimmern. Der Grund für die Zunahme an postinterventionell asymptomatischem Vorhofflimmern ist unklar. Diskutiert werden Ablations-bedingte Placeboeffekte, Änderungen des Arrhythmiemusters und Veränderungen im autonomen Nervensystem. Klinische Risikofaktoren, die das postinterventionelle Auftreten asymptomatischer Arrhythmie wahrscheinlich machen, konnten nicht identifiziert werden.

Mit dieser Studie konnte erstmals auch bei hochsymptomatischen Patienten ein wesentlicher Anteil asymptomatischer Arrhythmieepisoden nachgewiesen werden. Die Daten unterstreichen die Unzuverlässigkeit der vom Patienten berichteten subjektiv empfundenen Arrythmiedauer für klinische Entscheidungsfindungen wie die Indikation zur oralen Antikoagulation oder die Frage einer transösophagealen Echokardiographie vor elektrischer Kardioversion. Vom wissenschaftlichen Standpunkt betrachtet deuten die Ergebnisse der Studie eine signifikante Überschätzung der Erfolgsraten der Vorhofflimmerablation bei alleinig Symptom- 
orientierter Nachbeobachtung an. Methodik und Resultate der Arbeit haben Eingang in die Leitlinien gefunden, die aktuellen wissenschaftlichen Standard für eine objektive Nachbeobachtung innerhalb klinischer Vorhofflimmerstudien definieren ${ }^{50}$.

\section{Einfluss der Monitoringdauer auf die Detektionsrate von VHF}

Die Einführung von objektivem Rhythmusmonitoring als Standard der Nachkontrolle nach medikamentöser oder katheterinterventioneller Behandlung von Patienten mit Vorhofflimmern führte zur Frage der optimalen Monitoringdauer ${ }^{50}$. Prinzipiell ist eine Erfassung aller Arrhythmierezidive nur mit einer kontinuierlichen EKG-Aufzeichnung dauerhaft implantierter Geräte, wie beispielsweise bei Herzschrittmachern, möglich. Nicht invasive Methoden der EKG-Überwachung können dies nicht gewährleisten.

Zum besseren Verständnis der optimalen Dauer nicht invasiver Verfahren des Rhythmusmonitorings analysierten wir bei 215 konsekutiven Patienten 6 Monate nach Katheterablation die Rate an detektierten Vorhofflimmerrezidiven basierend auf einer 24-stündigen Zunahme des LzEKG-Monitorings mit einer Aufzeichnungdauer von insgesamt 1-7 Tagen. Mit dem maximal möglichen Aufzeichnungsfenster von 7 Tagen zeigte sich bei 64 Patienten (30\%) mindestens ein Rezidiv von Vorhofflimmern. Eine kürzere Dauer des LzEKG-Monitorings führte zu einer signifikanten Reduktion der Anzahl an Patienten bei denen Vorhofflimmerrezidive detektiert wurden. So konnten nach 24, 48, 72 und 96 Stunden LzEKG nur 59\%, $67 \%, 80 \%$ und $91 \%$ der Rezidiv-Patienten identifiziert werden. Eine Verlängerung der Dauer des Rhythmusmonitoring über 4 Tage hinaus führte zu keinem weiteren signifikanten Anstieg der Rate an Patienten mit Vorhofflimmer-Detektionen. 
Obwohl die Studie für die Nachkontrolle nach Vorhofflimmerablation eine optimale Monitoringdauer von mindestens 4 Tagen LzEKG-Aufzeichnung nahelegt, muss einschränkend festgehalten werden, dass diese Daten sich auf den angewandten Goldstandard eines maximal möglichen Aufzeichnungsfensters von 7 Tagen beziehen. Vom wissenschaftlichen Standpunkt ist es derzeit unklar, ob eine weitere Verlängerung der Monitoringdauer in den Bereich von Wochen bzw. Monaten nicht zu einem weiteren signifikanten Anstieg der Rate an Patienten mit VorhofflimmerDetektionen führen würde. Erst die Entwicklung und Etablierung verlässlicher implantierbarer Monitoring-Devices wird diese Frage abschließend beantworten und eine wissenschaftlich fundierte Definition einer maximal nötigen Monitoringdauer nach Vorhofflimmerablation ermöglichen.

\section{Einfluss der Monitoringstrategie auf die Detektionsrate von VHF}

Parallel zum seriellen 7-Tage-LzEKG wurden andere Strategien zum nicht invasiven Rhythmusmonitoring nach Vorhofflimmerablation entwickelt. Breiten Einsatz finden diesbezüglich regelmäßige Symptom-unabhängige transtelephonische EKGÜbertragungen. Verglichen mit dem seriellen 7-Tage-LzEKG hat jede dieser Strategien spezifische Vor- und Nachteile. Das 7-Tage-LzEKG bietet eine kontinuierliche Rhythmusüberwachung innerhalb eines breiten Aufzeichnungsfensters, asymptomatische Vorhofflimmerepisoden zwischen den Registrierungen werden allerdings nicht erfasst. Mit regelmäßigen transtelephonischen EKG-Übertragungen werden die nicht abgedeckten Zeiträume zwischen den einzelnen Registrierungen deutlich kürzer, allerdings ist das kontinuierliche Aufzeichnungsfenster selbst nur sehr kurz, so dass asymptomatische 
Episoden außerhalb verloren gehen können, und eine genaue Charakterisierung der aufgezeichneten Arrhythmieepisoden nicht möglich ist.

Zum Vergleich der Aussagekraft beider Monitoringstrategien führten wir im Rahmen einer klinischen Studie bei 30 konsekutiven Patienten eine Nachbeobachtung nach Vorhofflimmerablation mit beiden Verfahren parallel durch. Einerseits erhielten die Patienten ein serielles 7-Tage-LzEKG unmittelbar nach Ablation sowie nach 3 und 6 Monaten. Andererseits übertrugen die Patienten regelmäßig und Symptomunabhängig alle 2 Tage ein transtelephonisches 12-Kanal-EKG über einen Zeitraum von 6 Monaten. Zusätzliche Übertragungen waren im Rahmen individueller Arrhythmiebeschwerden möglich.

Eine alleinig Symptom-orientierte Nachkontrolle ergab eine Erfolgsrate der Katheterintervention von 70\%. Diese Rate wurde durch serielles 7-Tage-LzEKG bzw. transtelephonisches EKG auf 50\% bzw. 45\% reduziert. Beide Verfahren zeigten eine hohe Übereinstimmung bei der Identifizierung von Patienten mit Vorhofflimmerrezidiven.

Vom klinischen Gesichtspunkt stellt das transtelephonische EKG somit ein gegenüber dem seriellen 7-Tage-LzEKG gleichwertiges Verfahren der objektiven Rhythmuskontrolle nach Vorhofflimmerablation dar. Wissenschaftlich betrachtet gelten für das transtelephonische EKG aber die gleichen Einschränkungen und Limitierungen eines nicht invasiven diskontinuierlichen Monitoring-Verfahrens, die für das 7-Tage-LzEKG oben bereits diskutiert wurden. 


\section{Originalarbeiten}

4.1. Entwicklungen der Bildintegration und einer Modell-gestützten Therapie

4.1.1. Elektroanatomische Rekonstruktion des linken Vorhofes, der Pulmonalvenen und des Ösophagus im Vergleich zur realen Anatomie im multislice CT bei Patienten mit Vorhofflimmerablation

Zitierweise:

Christopher Piorkowski, MD, Gerhard Hindricks, MD, Doreen Schreiber, Hildegard Tanner, MD, Wolfgang Weise, MD, Alexander Koch, MD, Jin-Hong Gerds-Li, MD, Hans Kottkamp, MD.

Electroanatomic reconstruction of the left atrium, pulmonary veins, and esophagus compared with the "true anatomy" on multislice computed tomography in patients undergoing catheter ablation of atrial fibrillation.

Heart Rhythm 2006;3:317-327. 


\title{
Electroanatomic reconstruction of the left atrium, pulmonary veins, and esophagus compared with the "true anatomy" on multislice computed tomography in patients undergoing catheter ablation of atrial fibrillation
}

\author{
Christopher Piorkowski, MD, * Gerhard Hindricks, MD, * Doreen Schreiber, * \\ Hildegard Tanner, MD, * Wolfgang Weise, MD, ${ }^{\dagger}$ Alexander Koch, MD, ${ }^{\dagger}$ \\ Jin-Hong Gerds-Li, MD, * Hans Kottkamp, MD*
}

From "Heart Center. Department of Electrophysiology and

${ }^{\dagger}$ Department of Radiology, University of Leipzig, Leipzig, Germany.

\begin{abstract}
BACKGROUND Current concepts of catheter ablation for atrial fibrillation (AF) commonly use threedimensional (3D) reconstructions of the left atrium (LA) for orientation, catheter navigation, and ablation line placement.

OBJECTIVES The purpose of this study was to compare the 3D electrosanatomic reconstruction (Carto) of the LA, pulmonary veins (PVs), and esophagus with the true anatomy displayed on multislice computed tomography (CT).

METHODS In this prospective study, 100 patients undergoing AF catheter ablation underwent contrast-enhanced spinal CT scan with barium swallow and subsequent multiplanar and 3D reconstructions. Using Carto, circumferential plus linear LA lesions were placed. The esophagus was tagged and integrated into the Carto map. RESULTS Compared with the true anatomy on CT, the electroanatomic reconstruction accurately displayed the true distance between the lower PVs; the distances between left upper PV, left lower PV, right lower PV, and center of the esophagus; the longitudinal diameter of the encircling line around the funnel of the left PVs; and the length of the mitral isthmus line. Only the distances between the upper PVs, the distance between the right upper PV and esophagus, and the diameter of the right encircling line were significantly shorter on the electroanatomic reconstructions. Furthermore, electroanatomic tagging of the esophagus reliably visualized the true anatomic relationship to the LA. On multiple tagging and repeated CT scans, the LA and esophagus showed a stable anatomic relationship, without relevant sideward shifting of the esophagus.

CONCLUSION Electroanatomic reconstruction can display with high accuracy the true 3D anatomy of the LA and PVs in most of the regions of interest for AF catheter ablation. In addition, Carto was able to visualize the true anatomic relationship between the esophagus and LA. Both structures showed a stable anatomic relationship on Carto and CT without relevant sideward shifting of the esophagus.
\end{abstract}

KEYWORDS AF; Catheter; Ablation; Carto; CT: Esophagus: Anatomy

(Heart Rhythm 2006:3:317-327) 02006 Heart Rhythm Society. All rights reserved.

Invasive therapy is increasingly used to treat patients with highly symptomatic atrial fibrillation (AF). Radiofrequency (RF) energy-induced lines encircling the pulmonary veins (PVs) outside the PV funnel at the level of

\footnotetext{
Address reprint requests and correspondence: Dr, Christopher $\mathrm{Pi}$ orkowski. Heart Center, Department of Electrophysiology. University of Leipzig. Strimpellstrasse 39, 04289 Leipzig, Germany.

E-mail address: cp7026@yahoo.de.

(Received October 18, 2005; accepted November 23, 2005.)
}

the left atrium (LA) combined with linear lesion lines connecting the circles and the mitral annulus revealed promising results and are increasingly used. ${ }^{t-5}$ The approach requires three-dimensional mapping systems to reconstruct the LA anatomy in order to facilitate threedimensional orientation and catheter navigation. ${ }^{1,2,4}$ In addition, because of the severe and potentially lethal risk for esophageal perforations during ablation, integration of an esophagus tag into the electroanatomic LA map 
visualizing the anatomic relationship has been studied and reported. ${ }^{6,7}$

The present study compared the electroanatomic reconstruction of the LA. PVs, and esophagus against the true anatomy displayed on contrast-enhanced multislice computed tomography (CT) scans.

\section{Methods}

\section{Patient selection and characteristics}

One hundred patients ( 75 men and 25 women, mean age 53 \pm 10 years) with highly symptomatic AF were included in this prospective study. Inclusion criteria were a history of AF for more than 18 months, previously ineffective antiarrhythmic drug therapy (at least one antiarrhythmic drug). and at least three documented AF episodes together with corresponding symptoms. Eighty-five $(85 \%)$ patients had paroxysmal $\mathrm{AF}$ and $15(15 \%)$ had persistent $\mathrm{AF}$. Persistent AF was defined as continuous arrhythmia throughout the 7-day Holter monitoring period prior to ablation. Organic heart disease was present in $22(22 \%)$ patients (coronary artery disease in 9 , valvular heart disease in 4 , dilated cardiomyopathy in 9$) .42(42 \%)$ patients had a history of arterial hypertension. and $49(49 \%)$ patients had so-called lone $A F$. Mean left ventricular ejection fraction was $61 \% \pm$ $9 \%$, and mean L.A diameter was $42 \pm 6 \mathrm{~mm}$. The median history of AF was 5 years (range $1-10$ years). AF ablation had been attempted previously in $32(32 \%)$ patients, and isthmus ablation for common atrial flutter had been performed in $11(11 \%)$ patients.

\section{Mapping and ablation procedure}

The ablation procedure was reported in detail previously. ${ }^{8}$ In brief, the electroanatomic mapping system (Carto. Biosense Webster. Diamond Bar, CA, USA) was used for reconstruction of the LA and navigation of the mapping/ablation catheter (NaviStar, Biosense Webster). All PVs were visited with the catheter, and vessel tagging was performed. The vein-atrium transition was determined by combining information from the fluoroscopic cardiac silhouette, impedance changes, and PVatrium electrogram characteristics, that is, fusion of the atrial electrogram component and the PV potential component. In addition, after reconstruction of the LA and before ablation. tagging of the esophagus was performed by advancing and withdrawing a Carto catheter covered by a conventional gastric tube in and out of the esophagus.

For ablation, circular lesions were deployed in the LA around the funnel of the PVs at the LA level. Additional linear lines were deployed between the circular lesions along the LA roof as well as between the left circular lesion and the mitral annulus. Individual adjustment of the lesion lines was performed as indicated from the esophageal course to prevent RF application in the direct vicinity of the esophagus.

\section{CT imaging technique}

The day before the ablation procedure, all patients underwent cardiac CT imaging using a multidetector four-row helical system (Somatom Volume Zoom. Siemens Medical Systems, Forchheim. Germany) as a standard imaging procedure. Patients swallowed $5 \mathrm{~mL}$ barium paste for contrast of the esophageal lumen. Data acquisition was performed in late diastole at a slice width of $2 \mathrm{~mm}$ and reconstruction increment of $1 \mathrm{~mm}$. Coverage was completed within one breath-hold period ( $25-30$ seconds). Imaging was initiated at the transaxial level of the aortic arch and carried caudally to cover the cardiac chambers. Nonionic iodinated contrast material (Imeron 300) was administered intravenously ( 80 $\mathrm{mL}$ at $2.5 \mathrm{~mL} / \mathrm{s}$ ).

Image data were reviewed using multiplanar reconstruction. maximum intensity projection, and three-dimensional volume rendering. Pathologic conditions influencing the esophageal course (e.g., esophageal tumors or hernias) were excluded on CT scans for all patients.

\section{Measurements}

\section{Definitions}

On CT, the PV ostium was defined as the reflection of the parietal pericardium at the point of intersection between the LA wall and the PV wall as seen on the two-dimensional source images. ${ }^{9}$ On Carto, the PV ostium was determined by combining information from the fluoroscopic cardiac silhouette, impedance changes, and PV-atrium electrogram characteristics and marked by placement of anatomic mapping points."

\section{Comparison between CARTO and CT}

Measurements on Carto and CT were performed independently by two different physicians blinded to each other's data. The following parameters were measured on Carto and CT (Figures I and 2): 1 = distance between the ostia of the left upper PV and right upper PV (RUPV), 2 = distance between the ostia of the left lower PV and the right lower PV, 3 = distance between the left upper PV ostium and the center of the esophagus, $4=$ distance between the right upper PV ostium and the center of the esophagus, $5=$ distance between the left lower PV ostium and the center of the esophagus, $6=$ distance between the right lower PV ostium and the center of the esophagus. In addition, the length of contact between the LA and the esophagus and the length of the mitral isthmus line (distance between the inferior left lower PV ostium and the mitral annulus) were determined and compared. Furthermore, on CT the longitudinal outer distance between the ostia of the left upper PV and the left lower PV and the longitudinal outer distance between the ostia of the right upper PV and the right lower PV were measured and compared with the maximum longitudinal diameter of the respective circular lesion on Carto. 

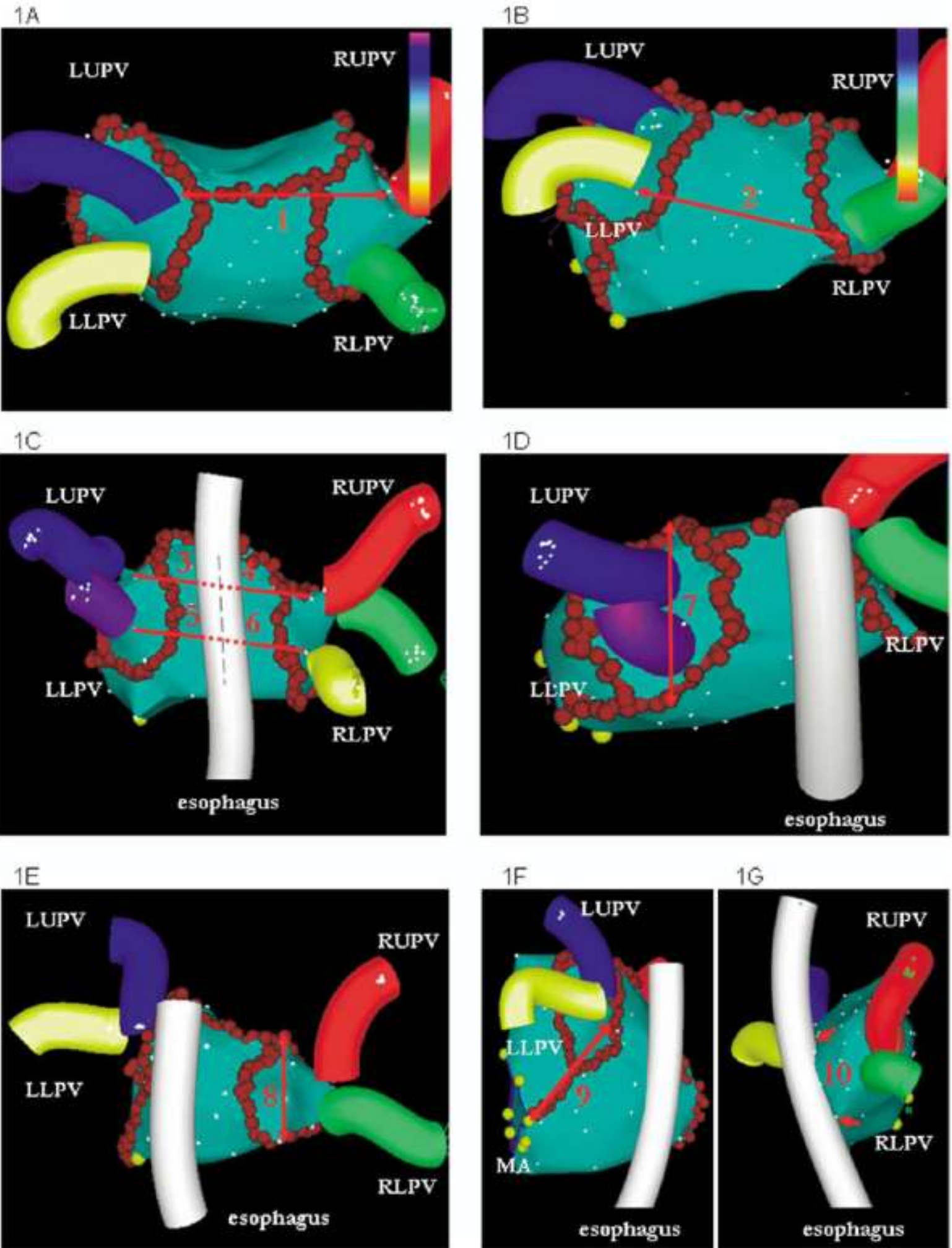

$1 \mathrm{~F}$

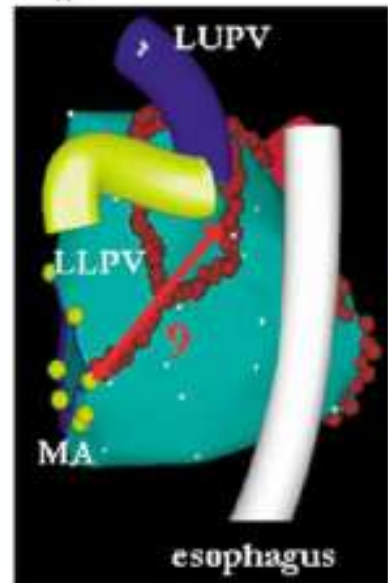

$1 G$

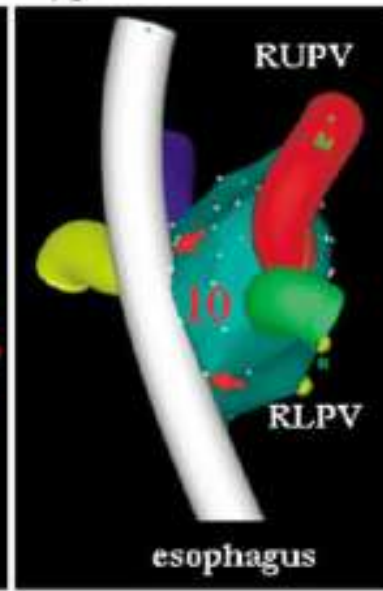

Figure 1 Left atrial (LA) diameters measured on Carto, comparing the electroantomic reconstruction against data from computed tomography. Red dots represent ablation lines. LLPV $=$ left lower pulmonary vein; LUPV $=$ left upper pulmonary vein; MA $=$ mitral annulus; RLPV = right lower pulmonary vein; RUPV $=$ right upper pulmonary vein; $1=$ distance between RUPV and LUPV ostia; $2=$ distance between RLPV and LLPV ostia; 3 = distance from LUPV to esophagus; 4 = distance from RUPV to esophagus; $5=$ distance from LLPV to esophagus; 6 = distance from RLPV to esophagus; 7 = longitudinal diameter of the encircling ablation line around the left PVs; $8=$ longitudinal diameter of the encircling ablation line around the right PVs; $9=$ mitral isthmus line; $10=$ length of contact between LA and esophagus. 

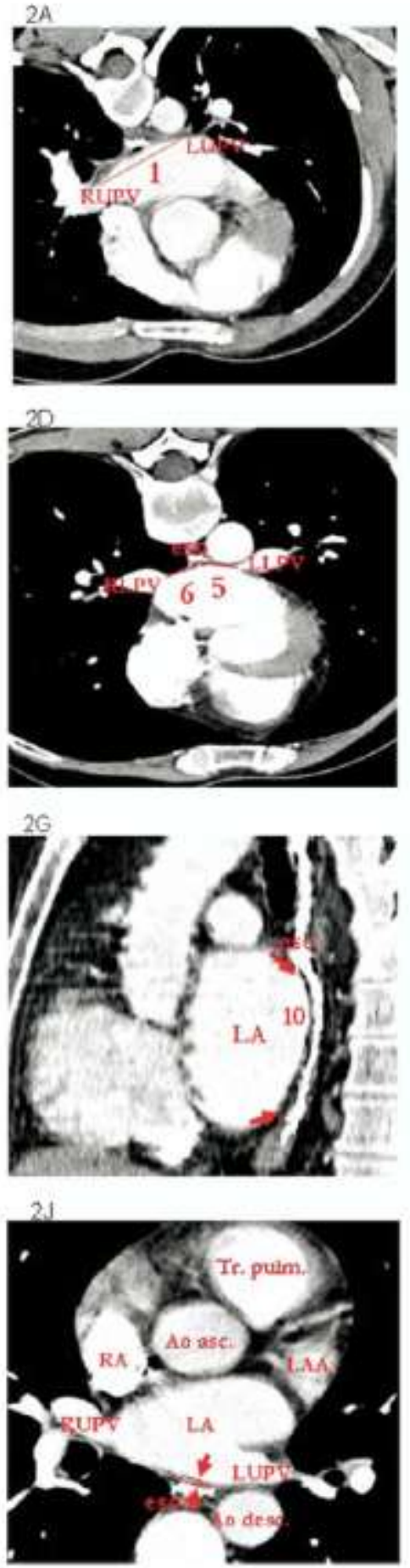
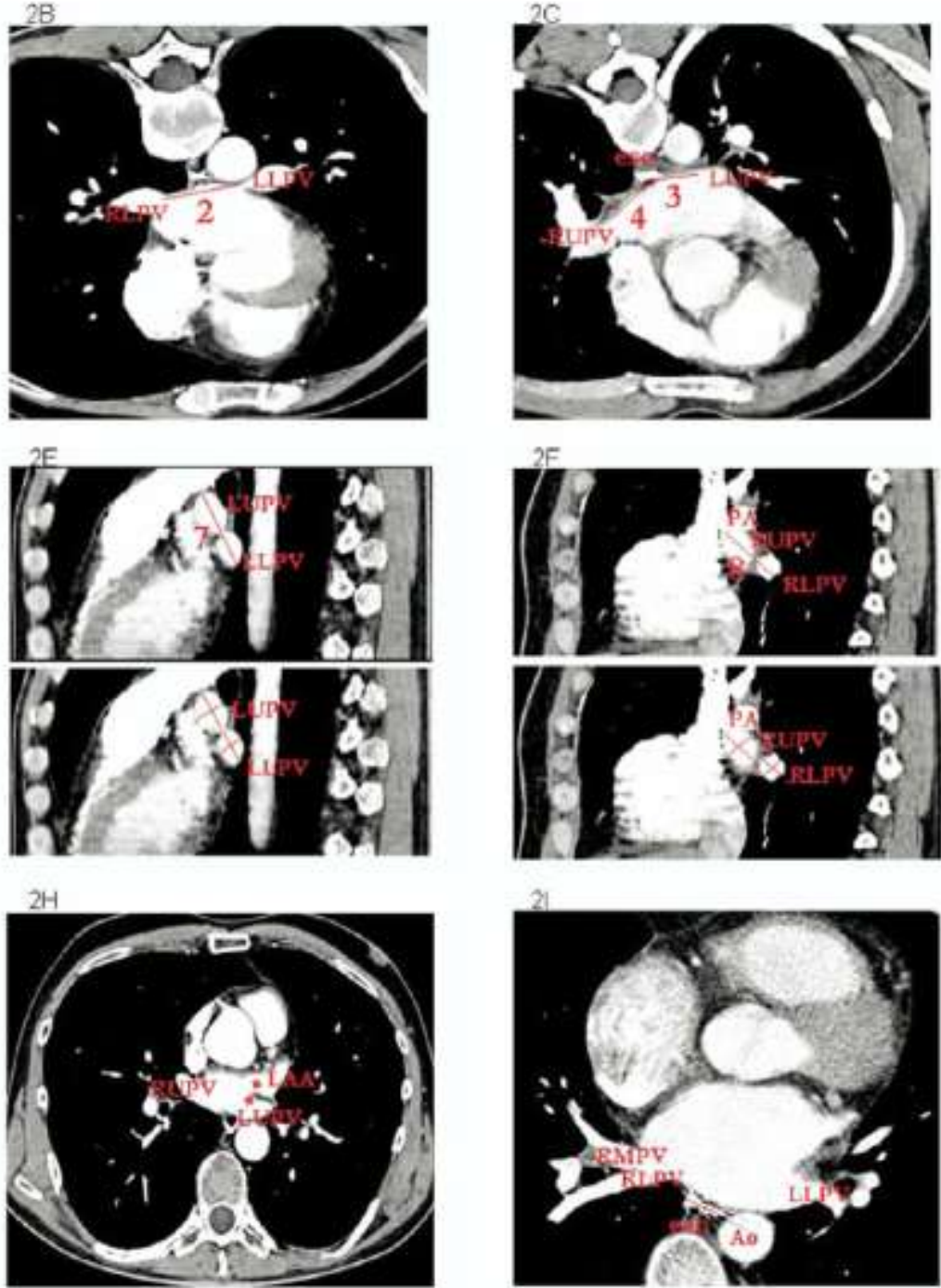

Figure 2 Left atrial (L.A) diameters measured on computed tomography, describing the true anatomy. $\mathrm{Ao}$ asc $=$ ascending aorta; $\mathrm{Ao}$ desc $=$ descending aorta; eso $=$ esophagus; $\mathrm{LA}=$ left atrium; $\mathrm{LAA}=$ left atrial appendage; $\mathrm{LLPV}=$ left lower pulmonary vein; $L U P V=$ left upper pulmonary vein; $R A=$ right atrium; $R L P V=$ right lower pulmonary vein; RUPV $=$ right upper pulmonary vein: $\operatorname{Tr}$ pulm $=$ common pulmonalis trunk; 1 = distance between RUPV and LUPV ostia; 2 = distance between RLPV and LLPV ostia; 3 = distance from LUPV to esophagus; 4 = distance from RUPV to esophagus; 5 = distance from LLPV to esophagus; 6 = distance from RLPV to esophagus: 7 = outer longitudinal diameter between LUPV and LLPV; 8 = outer longitudinal diameter between RUPV and RLPV; 10 $=$ length of contact between LA and esophagus.

\section{Additional CT parameters}

On CT, the following diameters also were assessed: minimal distance between esophageal and L.A lumen, width and depth of the esophagus, and longitudinal and vertical diameters of the PV ostia (Figure 2).

Visualization of the LA-esophageal relationship Using the PVs as landmarks, the area of the posterior LA was divided into 25 even fields (five columns [A-E], five rows [1-5]). For each of these fields, the course and contact of the esophagus were assessed and compared between Carto and CT (Figure 3).

\section{Stability of the LA-esophageal relationship}

In order to analyze the stability of the anatomic relationship between the LA and the esophagus possibly influenced by peristaltic, breath-dependent, or cardiac cycle-related changes, the esophagus was retagged four times on Carto in 

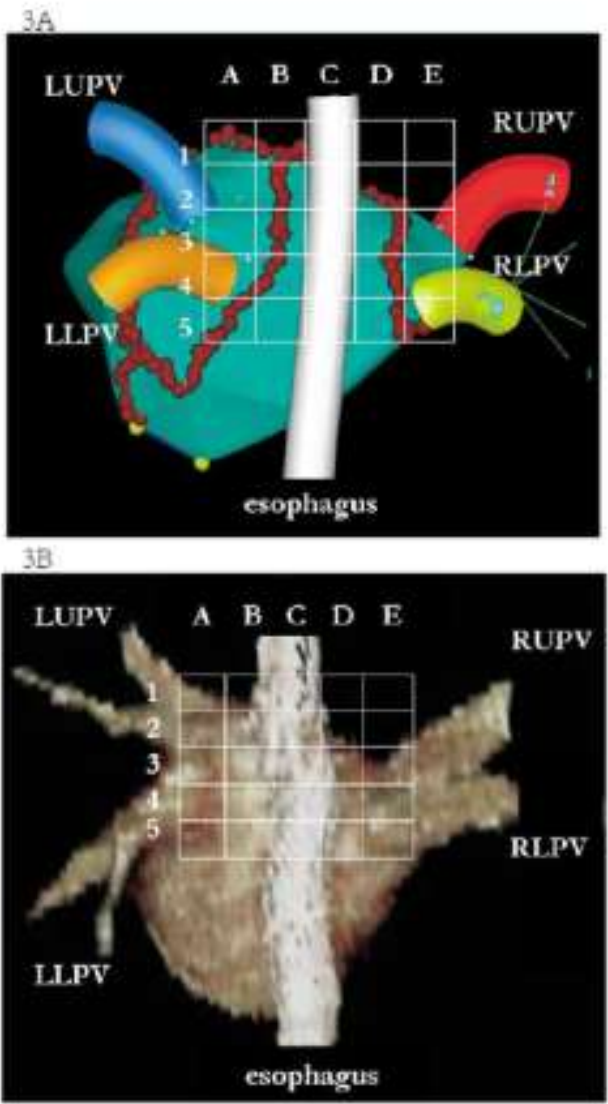

Figure 3 Assessment of the course and contact of the esophagus in relation to the posterior left atrium on Carto and computed tomography. The posterior left atrium is divided into a grid of five vertical columns $(A-E)$ and five horizontal rows $(l-5)$ adjusted at the landmark of the pulmonary veins. $\mathrm{A}=$ directly adjacent to the left pulmonary veins; $\mathrm{B}=$ located at the posterior left atrium toward the left pulmonary veins: $\mathrm{C}=$ located in the midportion of the posterior left atrium: $\mathrm{D}=$ located at the posterior left atrium toward the right pulmonary veins; $\mathrm{E}=$ directly adjacent to the right pulmonary veins; 1 = above the upper pulmonary veins; $2=$ at the level of the upper pulmonary veins; $3=$ between the upper and the lower pulmonary veins; $4=$ at the level of the lower pulmonary veins; $5=$ below the lower pulmonary veins. For each of the resulting 25 fields, course and contact were assessed in every individual patient. Red dots on Carto represent ablation lines. LLPV $=$ left lower pulmonary vein; LUPV = Ieft upper pulmonary vein; RLPV = right lower pulmonary vein; RUPV = right upper pulmonary vein.

20 patients. At three LA levels (roof, midportion, and bottom), the maximum distance between the esophageal tags was measured, Furthermore, for eight patients with reablation, the anatomic parameters describing the location and contact of the esophagus were measured and compared on two different CT scans taken 6 months apart.

\section{Statistical analysis}

Continuous variables are presented as mean $\pm \mathrm{SD}$, if appropriate. In case of a nongaussian distribution, median and quartiles are given. Categorical variables are expressed as number and percentage of patients.

Differences of continuous data (e.g., LA diameters) measured on Carto and CT were tested for statistical significance using the paired t-test. Differences of categorical data (e.g.. number of patients within the five columns of the esophageal course and number of patients with contact at the five levels of the posterior LA wall) between Carto and CT were tested for statistical significance using the $\mathrm{McNe}$ mar test. For patients with reablation and a second CT scan, differences between the LA diameters on the two different scans were tested for statistical significance using the paired t-test.

The average deviation between Carto and respective CT measurements, as well as between repeated CT measurements in cases of reablation, was generated for every parameter studied using the Bland-Altman plot (Tables 1 and 5).

\section{Results}

\section{LA anatomy on Carto and CT}

Table I summarizes the parameters measured on Carto and $\mathrm{CT}$. The electroanatomic LA reconstruction accurately displayed the true distance between the lower PVs $(46 \pm 8 \mathrm{~mm}$ vs $46 \pm 7 \mathrm{~mm}$ ); the distance between the left upper PV. left lower PV, right lower PV, and center of the esophagus (18 $\pm 8 \mathrm{~mm}$ vs $18 \pm 8 \mathrm{~mm}: 20 \pm 10 \mathrm{~mm}$ vs $19 \pm 8 \mathrm{~mm}: 27$ $\pm 9 \mathrm{~mm}$ vs $26 \pm 8 \mathrm{~mm}$ ); the longitudinal diameter of the encircling line around the funnel of the left PVs $(41 \pm 7 \mathrm{~mm}$ vs $41 \pm 8 \mathrm{~mm}$ ); and the length of the mitral isthmus line (36 $\pm 8 \mathrm{~mm}$ vs $37 \pm 9 \mathrm{~mm}$ ).

Only the distance between the upper PVs $(43 \pm 8 \mathrm{~mm}$ vs $49 \pm 8 \mathrm{~mm}, P=.001$ ), the distance between the right upper PV and esophagus ( $27 \pm 8 \mathrm{~mm}$ vs $31 \pm 8 \mathrm{~mm} ; P=.001)$. and the longitudinal diameter of the encircling line around the funnel of the right PVs $(37 \pm 6 \mathrm{~mm}$ vs $44 \pm 6 \mathrm{~mm}: P$ $=.001$ ) were significantly shorter on the electroanatomic reconstruction compared with the true CT anatomy. Additional parameters of the LA measured on CT are given in Table 2.

\section{Course and contact of the esophagus}

The minimal distance between the luminal esophageal surface and the luminal LA surface on CT was measured for all patients $(2.6 \pm 0.9 \mathrm{~mm})$. The distance berween the esophageal and the LA lumen was $<3 \mathrm{~mm}$ in $87 \%$ of patients.

The esophageal course and contact in relation to the posterior LA showed remarkable interindividual variability. Table 3 lists the main course of the esophagus on Carto and CT. In the majority of patients $(44 \%)$, the esophagus was positioned in the midportion of the posterior LA (C-course) (Figure 4). However, in $13 \%$ of patients, the esophagus was 
Table 1 Comparison of left atrial diameters between Carto and CT

\begin{tabular}{|c|c|c|c|c|}
\hline Parameter (mm) & Carto & $\mathrm{CT}$ & $P$ value & Average deviation \\
\hline LUPV ostium-RUPV ostium & $43 \pm 8$ & $49 \pm 8$ & .001 & $0.5 \pm 8.1$ \\
\hline LLPV ostium-RLPV ostium & $46 \pm 8$ & $46 \pm 7$ & .961 & $3.8 \pm 7.6$ \\
\hline LUPV ostium-esophagus & $18 \pm 8$ & $18 \pm 8$ & .525 & $1.1 \pm 5.6$ \\
\hline RUPV ostium-esophagus & $27 \pm 9$ & $31 \pm 8$ & .001 & $0.6 \pm 6.8$ \\
\hline LLPV ostium-esophagus & $20 \pm 10$ & $19 \pm 8$ & .188 & $2.7 \pm 7.1$ \\
\hline RLPV ostium-esophagus & $27 \pm 9$ & $26 \pm 8$ & .424 & $2.7 \pm 6.8$ \\
\hline Superior LUPV ostium-inferior LLPV ostium & $41 \pm 7$ & $41 \pm 8$ & .628 & $1.1 \pm 7.6$ \\
\hline Superior RUPV ostium-inferior RLPV ostium & $37 \pm 6$ & $44 \pm 6$ & .001 & $0.9 \pm 7.3$ \\
\hline Mitral isthmus line & $36 \pm 8$ & $37 \pm 9$ & .209 & $1.7 \pm 10.6$ \\
\hline
\end{tabular}

Left atrial anatomic diameters for the regions of interest for atrial fibrillation catheter ablation, measured and compared for Carto and computed tomography (CT). Differences between the Carto and CT measurements were tested for statistical significance using the paired t-test. The average deviation between Carto and respective CT measurements was generated using the Bland-Altman plot and is given additionally.

$\mathrm{LLPV}=$ left lower pulmonary vein; LUPV = left upper pulmonary vein; RLPV = right lower pulmonary vein; RUPV = right upper pulmonary vein.

positioned directly adjacent to the ostia of the left PVs (A-course) (Figure 4). In the remaining patients, the esophagus was positioned at the posterior LA toward the left PVs $(37 \%)(B$-course) and toward the right PVs $(6 \%)$ (D-course) (Figure 4). The esophagus was positioned adjacent to the ostium of the right lower PV ( $E$-course) in only one patient. Table 4 lists direct contact between the esophagus and LA at different LA levels for Carto and CT. At the posterior inferior LA, direct contact between the two structures significantly increased. From level 3 downward (below the upper PVs). the esophagus was in direct contact with the LA in almost all patients (Table 4).

When comparing the distribution of the course and contact of the esophagus within the 25 fields of the posterior LA, Carto and CT showed an overall concordance of $86 \%$ $\pm 15 \%$ for the esophageal course and $85 \% \pm 14 \%$ for esophageal-LA contact. However, the length of contact between the esophagus and LA was significantly shorter on Carto compared with the CT scans $(33 \pm 8 \mathrm{~mm}$ vs $49 \pm 12$ mm; $P=.001$ ). Analysis and comparison of the esophageal- LA contact above the lower PVs (Carto $13 \pm 6 \mathrm{~mm}$; CT $19 \pm 8 \mathrm{~mm} ; P=.001$ ) and below the lower PVs (Carto 21

Table 2 Additional diameters measured on CT

\begin{tabular}{lr}
\hline Parameter (mm) & Measurement \\
\hline Lumen esophagus-lumen left atrium & $2.6 \pm 0.9$ \\
LUPV ostium-left atrial appendage & $4.8 \pm 1.9$ \\
LUPV horizontal & $12.3 \pm 2.8$ \\
LUPV vertical & $21.5 \pm 3.9$ \\
LUPV horizontal & $12.7 \pm 3.3$ \\
L.PV vertical & $15.9 \pm 3.3$ \\
RUPV horizontal & $15.1 \pm 3.4$ \\
RUPV vertical & $27.7 \pm 4.2$ \\
RLPV horizontal & $14.6 \pm 3.2$ \\
RLPV vertical & $16.1 \pm 3.4$ \\
Width of the esophagus & $15.1 \pm 3.3$ \\
Depth of the esophagus & $6.9 \pm 2.2$ \\
\hline
\end{tabular}

Additional anatomic parameters of the left atrium, relevant for ablation line placement. For these parameters, measurements were possible on computed tomographic (CT) scans only.

LLPV = left lower pulmonary vein: LUPV = left upper pulmonary vein: RLPV - right lower pulmonary vein; RUPV - right upper pulmonary vein $\pm 8 \mathrm{~mm}:$ CT $29 \pm 9 \mathrm{~mm}: P=.001$ ) revealed an underestimation of contact on Carto toward the LA roof as well as toward the LA bottom.

\section{Stability of the LA-esophageal relationship}

Figure 5 displays the results of multiple esophageal tagging for assessment of the stability of the esophageal course. The maximum deviation of the esophageal course measured at three LA levels (roof. midportion, bottom) is given. Toward the LA roof, the esophagus detached from the LA and showed certain mobility with a maximum deviation of 10 $\mathrm{mm}$ in 2 (10\%) patients. However, toward the midportion and inferior LA, the esophagus was in very close proximity with the LA, with direct contact in most patients (Table 4) and with only minimal deviation of the esophageal course in case of multiple tagging (Figure 5).

Table 5 lists the distances between the PV ostia and the center of the esophagus for the initial CT scan and the CT scan obtained prior to reablation in the eight patients undergoing repeat ablation 6 months after the index procedure. In addition, the average deviation between the

Table 3 Course of the esophagus behind the posterior left atrium on Carto and CT

\begin{tabular}{llll}
\hline Course & Carto & CT & $P$ value \\
\hline A & $15(15 \%)$ & $13(13 \%)$ & 1.0 \\
B & $28(28 \%)$ & $37(37 \%)$ & .115 \\
C & $48(48 \%)$ & $44(44 \%)$ & .405 \\
D & $9(9 \%)$ & $6(6 \%)$ & .375 \\
\hline
\end{tabular}

Course of the esophagus behind the posterior left atrium on Carto and computed tomography (CT).

Differences in the number of patients in each of the five location groups between Carto and $\mathrm{CT}$ were tested for statistical significance using the McNemar test.

A - no. of patients with an esophagus directly adjacent to the left pulmonary veins; $B$ - no. of patients with an esophagus at the posterior left atrium located toward the left putmonary veins; $\mathrm{C}=$ no. of patients with an esophagus in the midportion of the posterior left atrium; $D=$ no. of patients with an esophagus at the posterior left atrium located toward the right pulmonary veins. 
$4 \mathrm{~A}$
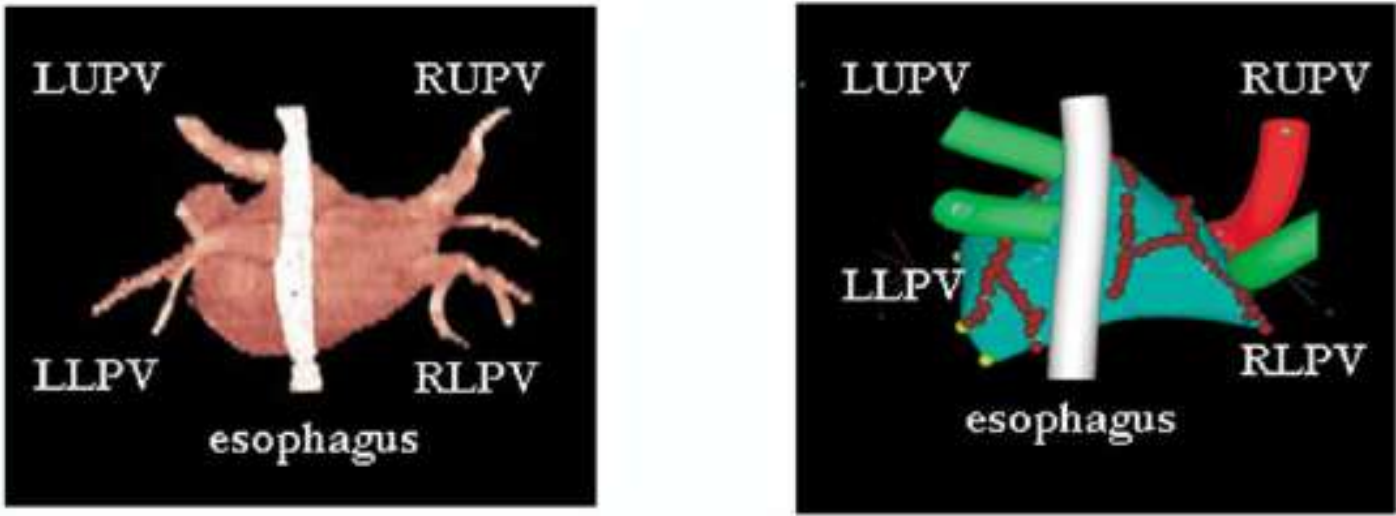

$4 \mathrm{~B}$
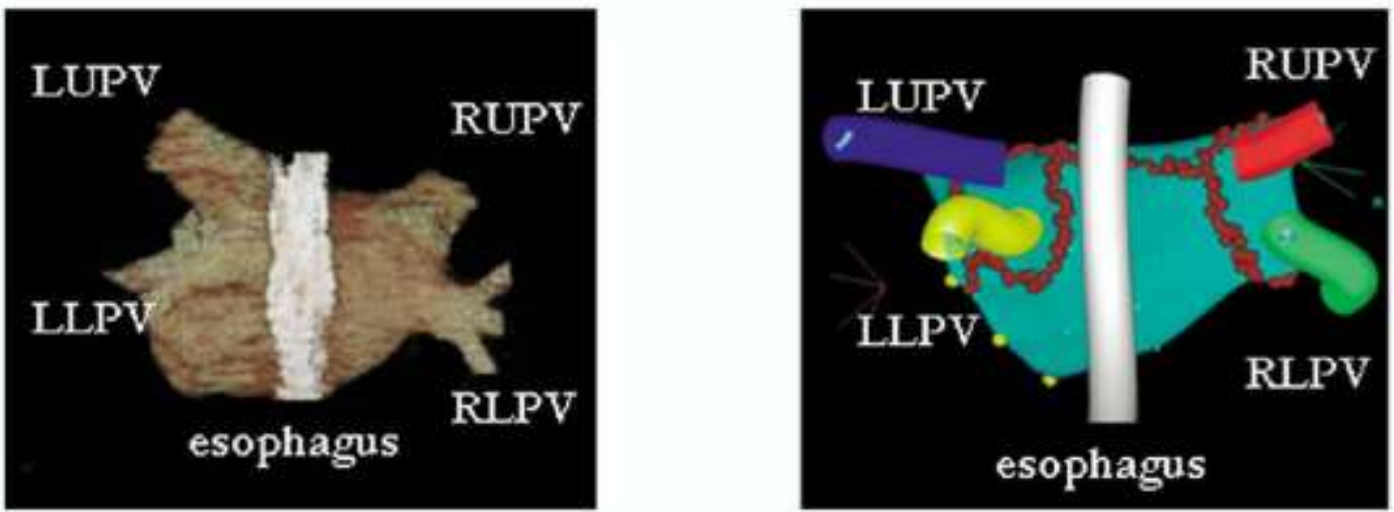

$4 \mathrm{C}$
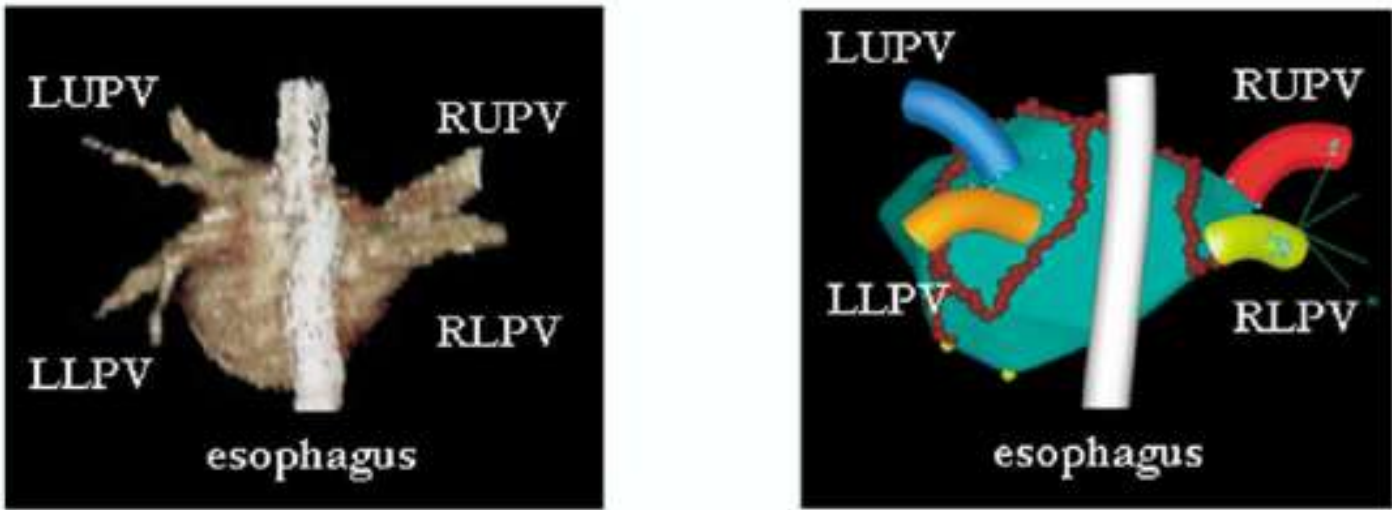

$4 \mathrm{D}$
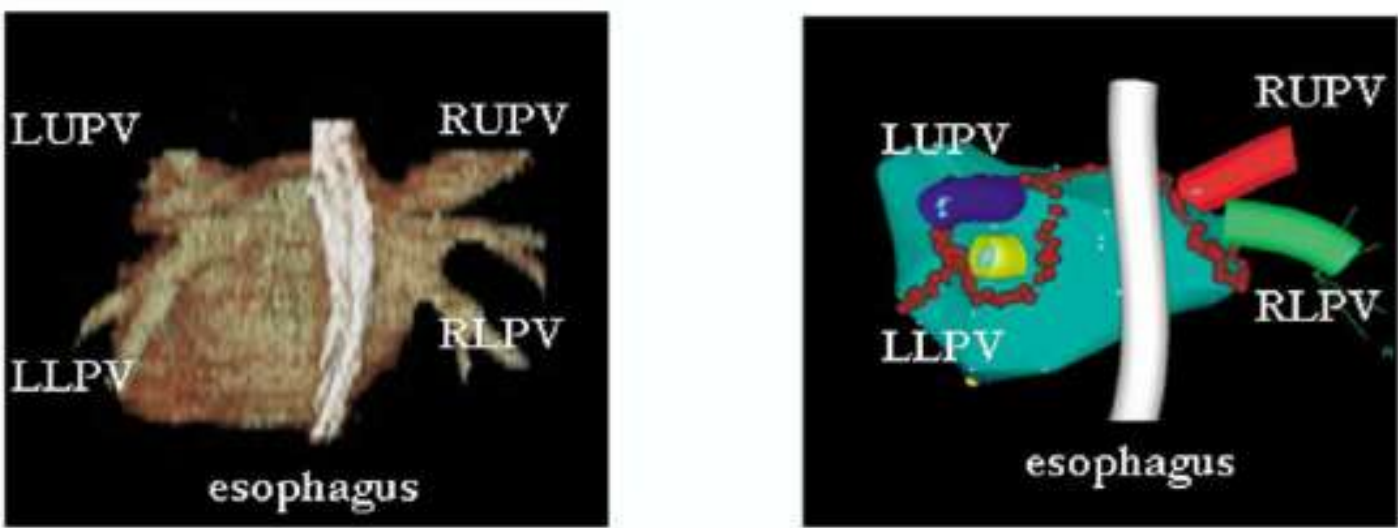

Figure 4 Three-dimensional computed tomographic images and Carto maps of four different patients with different locations of the esophagus in relation to the posterior left atrium. A: Patient with A-course of the esophagus. B: Patient with B-course of the esophagus. C: Patient with C-course of the esophagus. D: Patient with D-course of the esophagus. LLPV = left lower pulmonary vein; LUPV $=$ left upper pulmonary vein; RLPV = right lower pulmonary vein; RUPV = right upper pulmonary vein. 
Table 4 Contact between esophagus and left atrium at different left atrial levels

\begin{tabular}{lccc}
\hline $\begin{array}{l}\text { Level at the } \\
\text { posterior } \\
\text { left atrium }\end{array}$ & Carto & CT & P value \\
\hline 1 & $0(0 \%)$ & $3(3 \%)$ & .25 \\
2 & $50(50 \%)$ & $64(64 \%)$ & .004 \\
3 & $88(88 \%)$ & $92(92 \%)$ & .219 \\
4 & $99(99 \%)$ & $97(97 \%)$ & .5 \\
5 & $92(92 \%)$ & $89(89 \%)$ & .1 \\
\hline
\end{tabular}

Contact of the esophagus with the posterior left atrium on Carto and computed tomography (CT).

Differences in the number of patients with contact in each of the five levels between Carto and CT were tested for statistical significance using the McNemar test.

$1=$ no. of patients with contact above the upper pulmonary veins; $2=$ no. of patients with contact at the level of the upper pulmonary veins; $3=$ no. of patients with contact between the upper and lower pulmonary veins; $4=$ no. of patients with contact at the level of the lower pulmonary veins; 5 - no. of patients with contact below the lower putmonary veins.

two CT scans is given for each parameter. Concordant with multiple tagging of the esophagus on Carto, repeated measurements on CT supported a stable anatomic relationship in the contact area at the midportion and inferior L.A (Table 5 and Figure 6).

\section{Discussion}

\section{Main findings}

The results of our study show that electroanatomic reconstruction can display with high accuracy the true

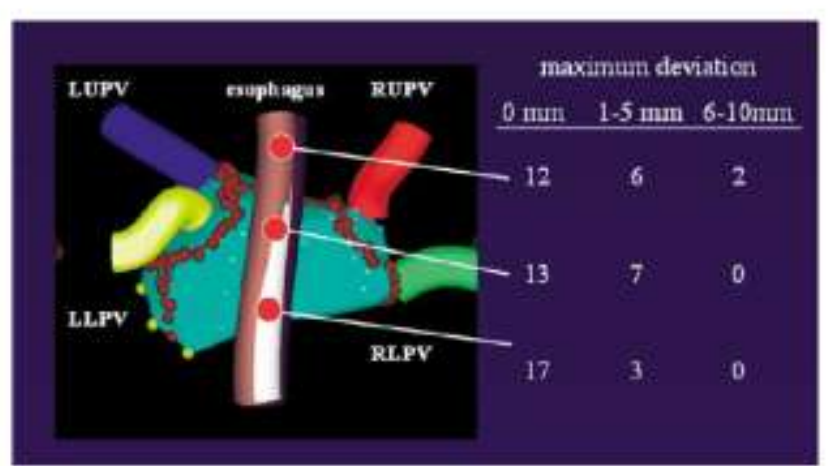

Figure 5 Results of multiple esophageal tagging for assessment of mobility of the esophagus in relation to the posterior left atrium. Posteroanterior view of an electroanatomic reconstruction of the left atrium with multiple tagging of the esophagus (shown by different colors mixing in the electroanatomic esophagus tubes) is shown. The results of measurement of the maximum deviation of the esophageal tube in case of multiple tagging are shown for the three measurement points next to the Carto image, LLPV = left lower pulmonary vein; $L U P V=$ left upper pulmonary vein; RLPV $=$ right lower pulmonary vein; RUPV $=$ right upper pulmonary vein.
Table 5 Comparison of left atrial diameters on two CT scans in eight patients undergoing reablation

\begin{tabular}{lllll}
\hline Parameter (mm) & CT1 & CT2 & $\begin{array}{c}P \\
\text { value }\end{array}$ & $\begin{array}{c}\text { Average } \\
\text { deviation }\end{array}$ \\
\hline LUPV ostium-RUPV ostium & $48 \pm 4$ & $47 \pm 5$ & .378 & $1.8 \pm 1.5$ \\
LLPV ostium-RLPV ostium & $45 \pm 8$ & $46 \pm 9$ & .133 & $1.4 \pm 0.9$ \\
LUPV ostium-esophagus & $19 \pm 4$ & $20 \pm 6$ & .654 & $2.2 \pm 1.9$ \\
RUPV ostium-esophagus & $29 \pm 6$ & $28 \pm 9$ & .59 & $4.2 \pm 2.3$ \\
LLPV ostium-esophagus & $19 \pm 8$ & $19 \pm 7$ & .929 & $2.4 \pm 2.1$ \\
RLPV ostium-esophagus & $28 \pm 12$ & $27 \pm 12.632$ & $3.6 \pm 3.2$ \\
$\begin{array}{l}\text { Superior LUPV-inferior } \\
\text { LLPV }\end{array}$ & $43 \pm 4$ & $43 \pm 4$ & .567 & $1.4 \pm 1.0$ \\
$\begin{array}{l}\text { Superior RUPV-inferior } \\
\quad \text { RLPV }\end{array}$ & $44 \pm 5$ & $45 \pm 5$ & .133 & $1.4 \pm 0.9$ \\
\hline
\end{tabular}

Left atrial anatomic diameters describing the region of interest for atrial fibrillation catheter ablation, measured on repeat computed tomographic (CT) scans obtained 6 months apart in case of reablations $(n=8)$. Differences between the two $\mathrm{CT}$ measurements were tested for statistical significance using the paired $t$-test. The average deviation between repeated CI measurements was generated using the Bland-Altman plot and is given additionally.

$\mathrm{LLPV}=$ left lower pulmonary vein; $L U P V=$ left upper pulmonary vein; RLPV = right lower pulmonary vein; RUPV = right upper pulmonary vein

anatomy of the LA, PVs, and esophagus in most of the regions of interest for $\mathrm{AF}$ catheter ablation. No significant differences between the Carto and CT parameters could be found, especially in the area around the left PVs. at the mitral annulus, and at the posterior LA wall. In addition, Carto was able to visualize the true anatomic relationship between the esophagus and LA. Furthermore, the LA and esophagus showed a stable anatomic relationship on Carto and $\mathrm{CT}$ without relevant sideward shifting of the esophagus.

\section{Accuracy of the electroanatomic LA reconstruction}

RF energy-induced ablation lines encircling the PVs outside the funnel at the atrial level combined with linear lesions connecting the circles and the mitral annulus are increasingly applied for curative treatment of AF. With such an approach, the region of interest for AF catheter ablation has moved from within the PV to the L.A level. The target areas for placement of ablation lines are around the left and right PV funnels, at the posterior LA wall, at the LA roof, and within the LA isthmus. Threedimensional reconstructions of the LA anatomy are used to guide placement of ablation lines within these target areas and to avoid damage to sensitive structures such as the PVs and the esophagus. No data analyzing the accuracy of the widely used, electroanatomically reconstructed LA anatomy are available. Our study is the first to compare the Carto map with the true anatomy obtained from multislice CT.

In our study, the CT parameters describing the LA match very well the previously published CT data on LA 
Figure 6 Posteroanterior view of the three-dimensional reconstruction of the computed tomographic (CT) image of the left atrium, including the pulmonary veins and the esophagus, in a patient with two catheter interventional ablation procedures for treatment of atrial fibrillation. A: CT scan prior to the first ablation. B: CT scan obtained 6 months later. prior to reablation. Both images show the same anatomic situation with a nearly identical position of the esophagus at the posterior left atrium. LLPV $=$ left lower pulmonary vein; $L U P V=$ left upper pulmonary vein: RLPV = right lower pulmonary vein; RUPV = right up-

$6 A$

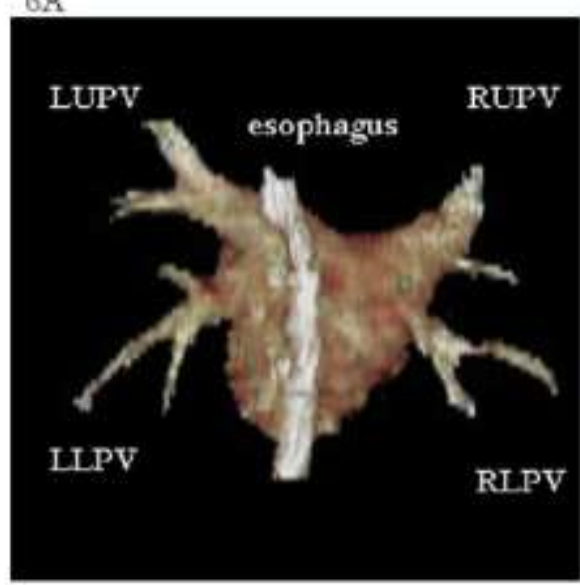

GB

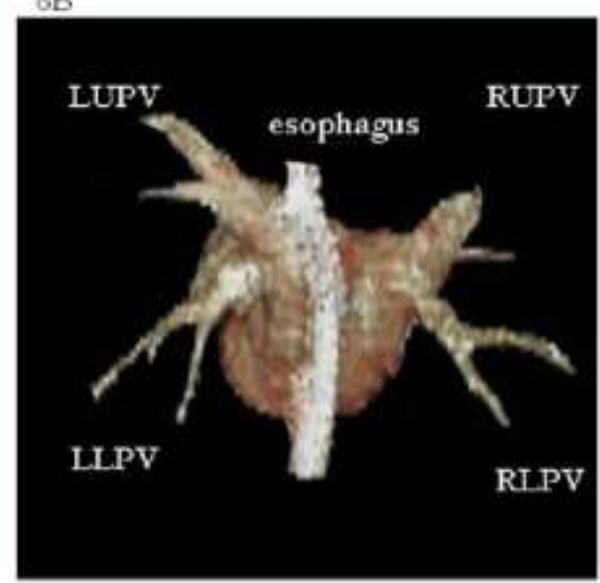
per pulmonary vein.

anatomy. ${ }^{9,10}$ The electroanatomic LA reconstruction accurately displayed most of these diameters. The LA isthmus and posterior LA showed an excellent concordance between Carto and CT, especially the parameters describing the area around the left PVs. Only the distances between the upper PVs, between the right upper PV and esophagus, and the longitudinal diameter of the encircling line around the funnel of the right PVs were, on average, 4 to $7 \mathrm{~mm}$ shorter on Carto compared with the true CT anatomy. The reason for the difference likely is related to current sheath and catheter technology. After transseptal LA access, free movement of the catheter around the ostia of the right PVs, which are located in the vicinity of the transseptal puncture site, is technically difficult. Therefore, stable and reliable catheter positions are difficult to achieve, with the inherent difficulties in obtaining accurate three-dimensional maps in that area. In this respect, our data may help to explain case reports of PV stenosis within the right lower PV despite a supposedly LA ablation procedure. ${ }^{11,12}$

\section{Anatomic relationship between the LA and esophagus}

Because of the risk for potentially lethal esophagus perforations during $\mathrm{AF}$ ablation. the anatomic relationship between the two structures has been subject to increasing attention. Our data on the distribution of the course and contact of the esophagus are concordant with previously published reports describing a variable and unpredictable location at the posterior LA for individual patients. ${ }^{6,10}$ The presence of a fat pad between the LA and the esophageal wall has been described as potentially protective against RF-induced perforations. ${ }^{10}$ However, in our series, the minimal distance between the esophageal endoluminal surface and the L.A endoluminal surface measured $<3 \mathrm{~mm}$ for $87 \%$ of patients. Cool-tip catheters are widely used and can create lesion depths up to $8 \mathrm{~mm}$. Therefore, with that energy source, ablation in an area with only $3 \mathrm{~mm}$ tissue thickness may result in perforation, regardless of the presence of a thin fat layer in between. Reduction and titration of ablation energy maty be inadequate for discriminating between desired transmurality and unwanted perforation. given a tissue thickness of only $3 \mathrm{~mm}$. Besides an ablation regimen that guides ablation duration according to electrogram reduction, one method for preventing esophageal perforations could be to avoid ablation within the contact area. Therefore, electroanatomic tagging of the esophagus has been introduced as a strategy to visualize the anatomic relationship toward the LA during ablation in order to prevent RF energy application in the direct vicinity of the esophagus. ${ }^{6}$ The present study showed a high concordance between the esophageal-LA relationship on the electroanatomic reconstruction and the true anatomy on CT. Only the total length of contact was underestimated on the Carto map. Visualization of the esophagus necessitated adjustment of the left encircling line in $50 \%$ of patients and the right encircling line in $6 \%$ of patients. The connecting line between the circular lesions was moved from the posterior LA to the LA roof in all patients.

Questions regarding possibly significant mobility of the esophagus at the posterior LA wall have been raised. ${ }^{10.13}$ The present study is the first to systemically analyze the stability of the anatomic relationship between the esophagus and posterior LA in vivo. Multiple Carto tagging revealed a degree of mobility of the esophagus toward the LA roof, where the two structures detach from each other. On the other hand, at the midportion and inferior LA, the anatomic relationship was very close and stable, with no significant sideward shift of the esophagus. The high concordance between the esophageal location on CT scan and the Carto map. acquired on 2 
consecutive days, and the minor intraindividual variability on CT scans obtained 6 months later (prior to reablation) further support that point of view. The stable anatomic relationship observed in our cohort may be interpreted as inconsistent with individual reports describing relevant esophageal mobility. ${ }^{10,13}$ However, one must consider that these reports present fluoroscopic images after barium ingestion into the esophagus, which itself induces peristalsis. Furthermore, these fluoroscopic images show mobility of the barium-contrasted esophagus in relation to the vertebral column. The mobility in relation to the posterior LA could not be described using that method. Therefore, the observed shifting of the barium-contrasted esophagus on fluoroscopy can be the result of a mixture of peristaltic, breath-dependent, and cardiac cycle-related shifting within the mediastinum and pressure influence from the diaphragm with gradual esophageal herniation, rather than a significant sideward shift of the esophagus in relation to the posterior LA wall.

\section{Study limitations}

Our study represents a single-center experience. Differences in catheter and sheath materials, transseptal access, and catheter handling may influence the accuracy of the Carto map.

Accurate identification of the PV ostium influences the anatomy obtained on Carto as well as its comparison against respective CT scans. Currently there is no known gold standard. Exactly defining the venoatrial junction may be difficult even on anatomic preparations ${ }^{14}$; therefore, for both methods (Carto and CT), we used previously published definitions for determining the PV ostium. $^{8,9}$

The resolution of CT scans is a limiting factor, especially with regard to accurate assessment of very short distances. In our study, the minimal distance between the esophageal and the LA luminal surface may be affected by this limitation.

The gastric tube used to cover the esophageal tagging catheter could have contributed to the picture of a stable esophageal course observed in our study. However, highly concordant esophageal courses on Carto and CT, as well as on repeat CT scans, argue against a major stabilizing effect from the tagging tube.

\section{Clinical implications}

Our data show that an electroanatomic LA reconstruction using Carto was able to accurately display most of the relevant parts of the LA anatomy targeted for ablation line placement during AF catheter ablation. In that sense, electroanatomic reconstruction provided the basis for reliable three-dimensional orientations and catheter navi- gation within the LA, which is mandatory for effective line placement and ablation success. In addition, it provided the opportunity to visualize online the true anatomic relationship with sensitive structures, such the PVs and esophagus, during ablation and thus avoid damage to those structures (e.g., potentially lethal esophagus perforation).

With regarding to the difficulty in describing the LA anatomy around the right PVs. future developments in catheter and sheath technology may help to enhance the range of catheter movement within the LA, thus improving the mapping conditions around the ostia of the right PVs.

\section{References}

1. Pappone C, Rosanio S, Oreto G, Tocchi M, Gugliotta F, Vicedomini G. Salvati A, Dicandia C, Mazzone P. Santinelli V. Gulletta S, Chierchia S. Circumferential radiofrequency ablation of PV ostia. A new anatomic approach for curing atrial fibrillation. Circulation 2000:102. 2619-2628.

2. Oral H. Knight BP. Tada H, Oraydin M, Chugh A, Hassan S, Scharf C. Lai SW, Greenstein R, Pelosi F Jr, Strickberger SA, Morady F. PV isolation for paroxysmal and persistent atrial fibrillation. Circulation 2002:105:1077-1081

3. Kottkamp H. Hindricks G. Autschbach R. Krauss B. Strasser B. Schirdewahn P, Fabricius A. Schuler G, Mohr FW, Specific linear left atrial Jesions in atrial fibrillation: intraoperative radiofrequency ablation using minimally invasive surgical techniques, J Am Coll Cardiol $2002 ; 40 ; 475-480$

4. Emst S, Ouyang F, Lober F, Antz M, Kuck KH. Catheter-induced linear lesions in the left atrium in patients with atrial fibrillation. J Am Coll Cardiol 2003:42:1271-1282

5. Ouyang F, Bänsch D, Ernst S, Schaumann A. Hachiya $H$, Chen $M$. Chun J. Falk P, Khanedani A, Antz M, Kuck KH. Complete isolation of left atrium surrounding the pulmonary veins. New insights from the double-lasso technique in paroxysmal atrial fibrillation. Circulation 2004:110:2090-2096.

6. Kottkamp H. Piorkowski C, Tanner H. Kobza R. Dorszewski A Schirdewahn P, Gerds-Li JH, Hindricks G. Topographic variability of the esophageal-left atrial relation influencing ablation lines in patients with atrial tibrillation. I Cardiovasc Electrophysiol 2065: 16:146-150,

7. Pappone C. Oral H. Santinelli V, Vicedomini G, Lang CC, Manguso F. Torracca L Benussi S, Alfieri O, Hong R. Lau W. Hirata K. Strikuma N, Hall B. Morady F. Atro-esophageal fistula as a complication of percutaneous transcatheter ablation of atrial fibrillation. Circulation 2004; 109.2724-2726.

8. Kottkamp H, Tanner H, Kobza R, Schirdewahn P, Dorszewski A. Gerds-Li JH. Carbucicchio C. Piorkowski C. Hindricks G. Time courses and quantitative analysis of atrial fibrillation episode number and duration after circular plus finear left atrial lesions: trigger elimination or substrate modification: early or delayed cure? J Am Coll Cardiol 2004:44:869-877.

9. Schwartzman D, Lacomis J, Wigginton WG. Characterization of left utrium and fistal pulmonary vein morphology using multidimensional computed tomography. J Am Coll Cardiol 2003;41: $1349-1357$.

10. Lemola K, Sneider M, Desjardins B, Case 1, Han J. Good E. Tamirisa K. Tsemo A, Chugh A. Bogun F, Pelosi F, Kazerooni E Morady F, Oral H. Computed tomographic analysis of the anatomy of the left atrium and the esophagus. Circulation 2004:110:36553660 . 
11. Vasamreddy CR, Jayam V. Bluemke DA, Calkins H. Puimonary vein occlusion: An unanticipated complication of catheter ablation of atrial fibrillation using the anatomic circumferential approach. Heart Rhythm 2004;1:78-81.

12. Vasamreddy CR. Dalal D, Eldadah Z, Dickfeld T. Jayam VK. Henrickson C, Meininger G, Dong J, Lickfett L, Berger R, Calkins H.
Safety and efficacy of circumferential pulmonary vein catheter ablation of atrial fibrillation. Heart Rhythm 2005;2:42-48.

13. Han J, Good E, Morady F, Oral H. Esophageal migration during left atrial catheter ablation for atrial fibrillation. Circulation 2004;110;e528.

14. Asirvatham SJ. Methods to identify the pulmonary vein ostium. Heart Rhythm 2005;2:1090-1093. 
4.1. Entwicklungen der Bildintegration und einer Modell-gestützten Therapie

4.1.2. CT-Modell gestützte Ablation von Vorhofflimmern und atrialen MakroReentry-Tachykardien

Zitierweise:

Christopher Piorkowski, Simon Kircher, Arash Arya, Thomas Gaspar, Masahiro Esato, Sam Riahi, Andreas Bollmann, Daniela Husser, Charlotte Staab, Philipp Sommer, and Gerhard Hindricks.

Computed tomography model-based treatment of atrial fibrillation and atrial macrore-entrant tachycardia.

Europace (2008) 10, 939-948. 


\title{
Computed tomography model-based treatment of atrial fibrillation and atrial macro-re-entrant tachycardia
}

\author{
Christopher Piorkowski*, Simon Kircher, Arash Arya, Thomas Gaspar, Masahiro Esato, Sam Riahi, \\ Andreas Bollmann, Daniela Husser, Charlotte Staab, Philipp Sommer, and Gerhard Hindricks
}

Department of Electrophysiology, University of Leipzig, Heart Center, Strümpellstrasse 39, 04289 Leipzig, Germany

Received 2 February 2008; accepted after revision 12 May 2008; online pubtish-ahead-of-print 23 June 2008

\author{
KEYWORDS \\ Atrial fibrillation: \\ Ablation; \\ Three dimensional image: \\ Model-guided therapy
}

\begin{abstract}
Aims Accurate orientation within true three-dimensional (3D) anatomies is essential for the successful radiofrequency (RF) catheter ablation of atriat fibrillation (AF) and atrial macro-re-entrant tachycardia (MRT). In this prospective study, ablation of AF and MRT was performed exclusively using a pre-acquired and integrated computed tomography (CT) image for anatomical $3 D$ orientation without electro-anatomic reconstruction of the left atrium (LA).

Methods and results Fifty-four consecutive patients suffering from AF $(n=36)$ and/or MRT $(n=18)$ underwent RF catheter ablation. A 3D CT image was registered into the NavX-Ensite system without reconstruction of the atrial chamber anatomy. The quality of CT atignment was assessed and validated according to fluoroscopy information, electrogram characteristics, and tactile feedback at 31 predefined LA control points. The ablation of AF as well as mapping and ablation of MRT was performed within the 3D CT anatomy. In all patients, mapping and ablation could be performed without the reconstruction of the respective atrial chamber anatomy. The overall CT alignment was highly accurate with true surface contact in $90 \%(84 \% ; 100 \%)$ of the control points. Complete isolation of all putmonary vein (PV) funnels was achieved in 35 of 36 patients $(97 \%)$ with AF. In patients with persistent AF $(n=11)$, additional isolation of the posterior LA (box lesion) and the placement of a mitral isthmus tine were performed. The MRT mechanisms were as foltows: around a PV ostium $(n=6)$, perimitral $(n=4)$, through $L$ foof $(n=5)$, septal $(n=2)$, and around left atrial appendage $(n=1)$. After a follow-up of $122 \pm 33$ days, $22 / 25(88 \%)$ patients with paroxysmal $A F, 8 / 11$ (73\%) with persistent $A F$, and $16 / 18(89 \%)$ with MRT remained free from arrhythmia recurrences.

Conclusion For patients with AF and MRT, our study shows the feasibility of successful placement of complex linear ablation line concepts guided by an integrated 30 image anatomy alone rather than catheter-based virtual chamber surface reconstructions.
\end{abstract}

\section{Introduction}

Radiofrequency (RF) catheter ablation of atrial fibrillation (AF) and atrial macro-re-entrant tachycardia (MRT) has become an accepted potentially curative treatment approach. Because of the complex three-dimensional (3D) distributions of initiating triggers and perpetuating substrate, catheter ablation of the mentioned arrhythmias requires an accurate 3D visualization of the atrial anatomy.

\footnotetext{
*Corresponding author. Tel: +49341 8651413; fax: +493418651460.

E.mail address: cp7026ayahoo.de
}

To provide 3D orientation, currently, electro-anatomic mapping systems (EAM) are commonly being used to reconstruct a virtual 3D chamber anatomy through the acquisition of a limited number of anatomical surface location points derived from the position of the catheter tip and an extrapolation of the chamber surface in between these acquired ana. tomical points. ${ }^{1,2}$ However, the resolution and accuracy of such a virtual 3D chamber anatomy, solely based on EAM, are limited by the number of acquired anatomical surface location points and the reliability of a true surface location of the catheter tip in areas with difficult catheter access.

Published on behalf of the European Society of Cardiology. All rights reserved. The Author 2008.

For permissions please email: journals.permissions@oxfordjournals.org.

The ontine version of this article has been pubtished under an open access model. Users are entitled to use, reproduce, disseminate, or display the open access version of this article for non-commercial purposes provided that the original authorship is properly and fulty attributed; the Journal, Learned Society and Oxford University Press are attributed as the original place of publication with correct citation details given; if an article is subsequently reproduced or disseminated not in its entirety but only in part or as a derivative work this must be clearly indicated. For commercial re-use, please contact journats.permissionsicoxfordjournats.org. 
A more detailed appreciation of the complex left atrium (LA) anatomy can be obtained with 3D-anatomical chamber reconstructions derived from computed tomography (CT) or magnetic resonance imaging (MRI) studies. ${ }^{3,4}$ Superimposition of pre-acquired CT/MRI images onto the electroanatomic 3D-reconstruction is associated with an improved clinical outcome in AF ablation procedures. ${ }^{5}$ So far this image integration is based on registration involving landmark points and surface alignment. Currently, it is not clear which registration protocol provides the most accurate and reliable image integration. Therefore, until now, CT/ MRI imaging has been merely used in adjunction to the electro-anatomic reconstruction.

In the present prospective clinical study, ablation of AF and atrial MRT was performed in a larger patient population exclusively using a pre-acquired and integrated CT image for anatomical $3 \mathrm{D}$ orientation without electro-anatomic reconstruction of the LA.

\section{Methods}

\section{Patient characteristics}

In this prospective study, between May 2007 and September 2007, a total of 54 consecutive patients suffering from highly symptomatic drug-refractory AF $(n=36)$ and/or atrial MRT $(n=18)$ underwent RF catheter ablation at our institution ( 21 females, 33 males, mean age $61 \pm 10$ years). Out of the 36 patients with AF, 25 (69\%) suffered from paroxysmal and 11 (31\%) from persistent AF. Persistent AF was defined as documented AF lasting for more than 7 days.

Among 54 patients, structural heart disease was present in 23 (43\%) patients [coronary artery disease $(n=7)$, dilated cardiomyopathy $(n=8)$, and valvular heart disease $(n=9)]$. Arterial hypertension was present in $31(57 \%)$ patients. Lone AF was seen in 13 (24\%) patients. Left ventricular ejection fraction averaged $56 \pm 9 \%$. Left atrium diameter measured $44 \pm 9 \mathrm{~mm}$. The duration of the arrhythmia history had a median of 60 months (range: 8-252). Twenty-one of the 54 patients (39\%) had undergone prior AF ablation procedures.

Table 1 displays baseline characteristics for the three groups of patients with paroxysmal AF, persistent AF, and atrial MRT separately.

\section{Computed tomography imaging and segmentation}

Forty of $54(74 \%)$ patients received a cardiac CT imaging on a 64-slice helical system (Philips Brilliance $64 \mathrm{CT}$, Best, The Netherlands) as a standard imaging procedure within $24 \mathrm{~h}$ before electrophysiological study. For the remaining $14(26 \%)$ patients, thoracic CT studies were used, which had been acquired previously, either for prior AF ablation procedures $(n=13)$ or for clinical indications other than electrophysiological therapy planning $(n=1)$.

Data acquisition was performed during expiratory breath hold in late diastole with the following scan parameters: effective thickness $0.8 \mathrm{~mm}$, increment $-0.8 \mathrm{~mm}$, voltage $120 \mathrm{kV}$, tube current $500 \mathrm{mAs}$, rotation time $0.33 \mathrm{~s}$, and scan time $16-20 \mathrm{~s}$. Imaging was initiated at the transaxial level of the aortic arch and carried caudally to cover the cardiac chambers. Non-ionic-iodinated contrast material (Ultravist 370 , Schering AG, Berlin, Germany) was administered intravenously $(60 \mathrm{~mL}, 4 \mathrm{~mL} / \mathrm{s})$.

All CT data were uploaded onto the NavX-Ensite system (Endocardial Solutions, Inc., St Paul, MN, USA, version 7.0), by which segmentation and $3 \mathrm{D}$ reconstruction of the LA were performed using the incorporated segmentation software. The segmented anatomical 3D image was exported into the real-time mapping system for registration.

\section{Electrophysiological study and registration process}

Prior to the procedure, transoesophageal echocardiography was performed to exclude thrombus formation within the LA. Patients were studied under deep propofol sedation with continuous invasive monitoring of arterial blood pressure and oxygen saturation. Standard catheters were placed in the right ventricular apex and the coronary sinus.

Patients presenting with $\mathrm{AF}$ at the beginning of the procedure received an electrical cardioversion into sinus inythm (SR). In patients presenting with an atrial MRT entrainment mapping within the high right atrium (RA), the RA isthmus and the coronary sinus confirmed the LA origin of the macro-re-entrant circuit. ${ }^{6}$ A single trans-septal puncture was performed under fluoroscopic guidance to gain access to the LA. After trans-septal puncture, an initial intravenous bolus and repeated doses of heparin were administered to maintain an activated clotting time of $250-300 \mathrm{~s}$. The NavX-Ensite system (Endocardial Solutions, Inc., St Paul, MN, USA, version 7.0) was used for non-fluoroscopic 3D catheter orientation, CT image integration, activation mapping, and tagging of the ablation sites with the coronary sinus lead $5 / 6$ serving as system reference. Throughout the procedure, respiratory motion compensation of the NavX-EnSite system was used to stabilize the catheter image in the case of instability due to deep or changing breathing pattern. Trans-septal access and catheter navigation were performed with steerable sheath technology (Agilis, St Jude Medical, Inc., St Paul, MN, USA).

\section{Computed tomography registration}

For image integration, the 'Digital Image Fusion' (DIF) algorithm provided by NavX-EnSite (Endocardial Solutions, Inc., St Paul, MN, USA, version 7.0) was used. Among other features, DIF contains field scaling and morphing algorithms. Field scaling is designed to compensate for distortions in NavX anatomies caused by electrical field inhomogenities. Morphing artificially changes the NavX anatomy in order to improve the fit into a given $3 \mathrm{D}$ image. During our registration process, both these algorithms were intentionally not used.

A $7 \mathrm{Fr}$ catheter containing a deflectable decapolar $4 \mathrm{Fr}$ Lasso loop of variable diameter size $(15-25 \mathrm{~mm})$ (Optima, St Jude Medical, Inc., St Paul, MN, USA) was introduced into each pulmonary vein (PV) subsequently. Initial PV conduction was assessed. While backing out of each PV, anatomical points were acquired through all the 10 catheter poles simultaneously, using the automatic mode of anatomic point acquisition with the multipolar mapping catheter as 'Active EnGuide' (Figure 1A). The vein-atrium transition was determined combining information from the fluoroscopic cardiac silhouette, impedance changes, and PV-atrium electrogram characteristics. In this way, a separate anatomy for each of the four PVs was created (Figure 1B). These four PV anatomies served as the main anatomical structures for the integration of the $\mathrm{CT}$ image (Figure $1 C$ ). In order to align the Lasso-reconstructed PV anatomies with the CT-PVs, for each PV two to four anatomical landmarks were placed at corresponding locations between the NavX anatomy and the CT-PV surface. Care was taken to define the landmark on the NavX anatomy first and on the CT-PV second (and not vice versa), in order to bring the CT towards the NavX anatomy and to leave the morphology of the NavX anatomy itself unchanged (otherwise the morphing algorithm would have changed the NavX anatomy, which was not intended).

After the alignment of the Lasso-reconstructed PV anatomies with the CT-PVs, the multipolar mapping catheter was replaced by a $4 \mathrm{~mm}$ M-curve irrigated tip ablation catheter (IBI Therapy Cooled Path, St Jude Medical, Inc., St Paul, MN, USA). Further, fine adjustment of image integration was achieved through three additional landmarks (at the LA roof, at the basal posterior LA, and in the LA isthmus). These landmarks were visited with the ablation catheter tip according to fluoroscopy and electrogram information. Once the individual landmark was reached, the assumed corresponding 
Table 1 Patient characteristics

\begin{tabular}{|c|c|c|c|}
\hline & Paroxysmal AF $(n=25)$ & Persistent AF $(n=11)$ & MRT $(n=18)$ \\
\hline Age (years) ${ }^{a}$ & $60 \pm 8$ & $62 \pm 10$ & $57 \pm 15$ \\
\hline Male, $n(\%)$ & $15(60)$ & $7(64)$ & $11(\overline{6} 1)$ \\
\hline AF/MRT history (months) ${ }^{\mathrm{b}}$ & $60(27 ; 108)$ & $72(18 ; 132)$ & $72(36 ; 111)$ \\
\hline Arterial hypertension, $n(\%)$ & $17(68)$ & $7(64)$ & $7(39)$ \\
\hline Coronary artery disease, $n(\%)$ & $4(16)$ & $1(9)$ & $2(11)$ \\
\hline Dilated cardiomyopathy & $0(0)$ & $1(9)$ & 7 (39) \\
\hline Valvular heart disease, $n(\%)$ & $1(4)$ & $2(18)$ & $6(33)$ \\
\hline Mitral valve replacement $(n)$ & Mech. valve (1) & - & Mech. valve (4) \\
\hline Mitral valve reconstruction $(n)$ & - & Reconstruction (1) & Reconstruction (2) \\
\hline Aortic valve replacement $(n)$ & - & Mech. valve (1) & - \\
\hline Lone AF, $n(\%)$ & $9(36)$ & $2(18)$ & $2(11)$ \\
\hline Left atrial diameter $(\mathrm{mm})^{\mathrm{a}}$ & $37 \pm 9$ & $53 \pm 6$ & $47 \pm 5$ \\
\hline Left ventricular ejection fraction $(\%)^{a}$ & $64 \pm 6$ & $63 \pm 7$ & $50 \pm 15$ \\
\hline Prior AF ablation, $n(\%)$ & $2(8)$ & $3(\overline{27})$ & $16(89)$ \\
\hline
\end{tabular}

position on the CT surface was marked and this way the CT surface was pulled towards the tip of the ablation catheter, without further anatomical point acquisition or anatomy reconstruction.

\section{Assessment of alignment quality}

After completion of the registration process, the quality of $\mathrm{CT}$ alignment was assessed through several LA control positions, which had to be visited with the ablation catheter by two electrophysiologists independently. Control point location and surface contact were reached and verified according to fluoroscopy information, electrogram characteristics, and tactile feedback. For each of the control points, the position of the catheter tip in relation to the integrated CT surface was evaluated in a nominal fashion.

The following control positions were visited: septal, inferior, posterior, and superior mitral annulus; LA isthmus; tissue bridge between left atrial appendage (LAA) and left upper pulmonary vein (LUPV); anterior, inferior, posterior, and superior wall of each PV; left-sided, middle, and right-sided LA roof; left-sided, middle, and right-sided basal LA; and annular, middle, and posterior part of the LA septum (Figure 2).

To further verify the quality of the image integration process, ablation points were not marked as projection onto the CT surface or as 'Lesion at Mouse', but they were taken as '3D Lesion on EnGuide' representing the true $3 \mathrm{D}$ anatomical position of the tip of the ablation catheter, demonstrating the presence or the absence of surface contact to the CT image.

\section{Ablation procedure and follow-up}

In all patients, an additional catheter was used for the reconstruction of the oesophageal anatomy (Figure 3). The oesophageal anatomy and location were stored in the map. ${ }^{7}$

For the treatment of paroxysmal AF, circumferential LA ablation lines were placed around the antrum of the ipsilateral PVs (irrigated tip catheter, pre-selected tip temperature of $48^{\circ} \mathrm{C}$, and maximum power of 30-50W) (Figure 4A). On the basis of reduction in the electrogram amplitude, the ablation catheter was moved to the next ablation position. Ablation in contact areas between the LA and the oesophagus was avoided. In regions near to the oesophagus, maximum power was reduced to $30 \mathrm{~W}$, special attention was paid to local electrogram amplitude reduction, and the burning time was limited to $30 \mathrm{~s}$. After circumferential line placement, voltage and pace mapping along the ablation line were used to identify and close gaps. The isolation of all PVs with bidirectional block was the procedural endpoint. This was additionally verified by the placement of a multipolar circular mapping catheter within the encircled areas, which was performed by a second electrophysiologist not involved in the ablation part of the procedure.

In patients with persistent $A F$, isolation of the PVs was performed after electrical cardioversion into SR, as described earlier. Additionally, linear lesions were added at the LA roof and the basal posterior LA, the latter always being placed with only $30 \mathrm{~W}$ due to oesophageal vicinity. Completeness of the additional linear lesions was achieved and verified through voltage and pace mapping within the isolated posterior LA box (Figure 4B). Eventually, an LA isthmus line was placed as continuous and transmural as possible, however, without line continuity enforcement through epicardial ablation. The ablation of fragmented potentials, ablation within the coronary sinus, and RA ablations were not performed. The RA isthmus was only ablated in the case of clinically documented typical RA flutter.

In patients with atrial MRT, after CT registration, activation and entrainment mapping were performed in order to identify the re-entrant circuit. The electrical information was displayed on the integrated CT surface through colour-coded isochronal lines (Figure 5). After the detection of the macro-re-entrant circuit and ablation of the MRT, the PVs were assessed during SR. Complete isolation of all PV funnels was performed as described earlier.

At the end of the procedure, AF/MRT inducibility was tested in all patients using $20 \mathrm{~s}$ Burst stimulation at the effective atrial refractory period, but did not initiate any further ablation treatment. After ablation, anti-arrhythmic drugs were discontinued and patients were put on $\beta$-blocker only. Anticoagulation was initiated for 6 months. Proton pump inhibitors were added for 4 weeks.

Following inclusion into the study and prior to ablation, a continuous 7-day electrocardiogram (ECG) (Lifecard CF, DelmarReynolds Medical Inc., Irvine, (A, USA) was recorded in all patients. The ECG was repeated immediately after the ablation and after 3 months. In the case of symptoms outside the recording periods, the patients were advised to contact our institution or the referring physician to obtain an ECG documentation. Atrial fibrillation/ macro-re-entrant tachycardia longer than $30 \mathrm{~s}$ was considered as an episode of sustained arrhythmia recurrence. More than $27000 \mathrm{~h}$ of continuous ECG recording have been analysed to assess rhythm outcome.

\section{Statistics}

Continuous variables are presented as mean \pm standard deviation (SD), if appropriate. In the case of a non-Gaussian distribution, 
(A)

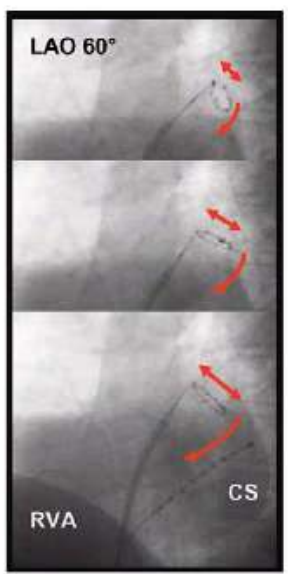

(B)
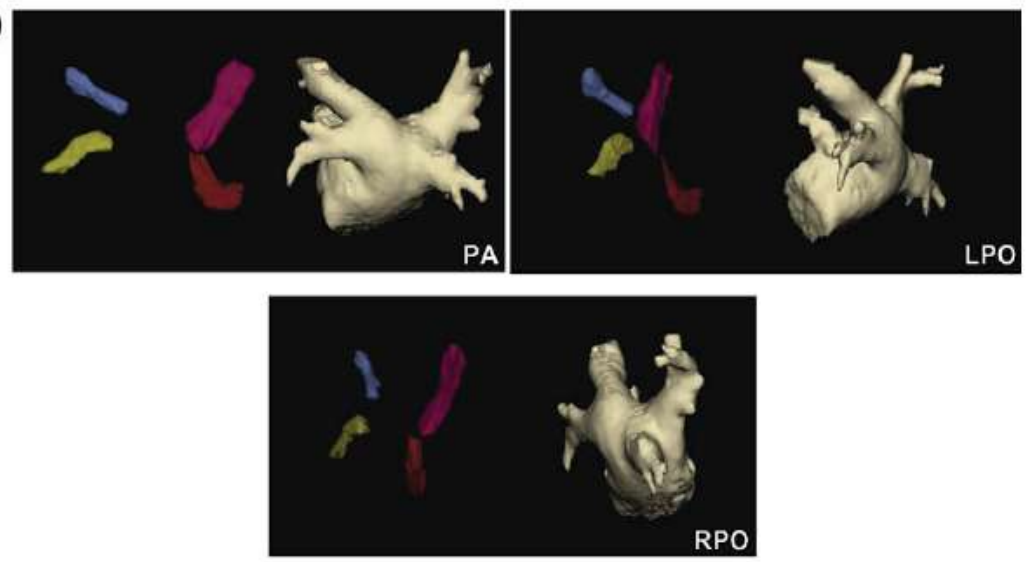

(C)
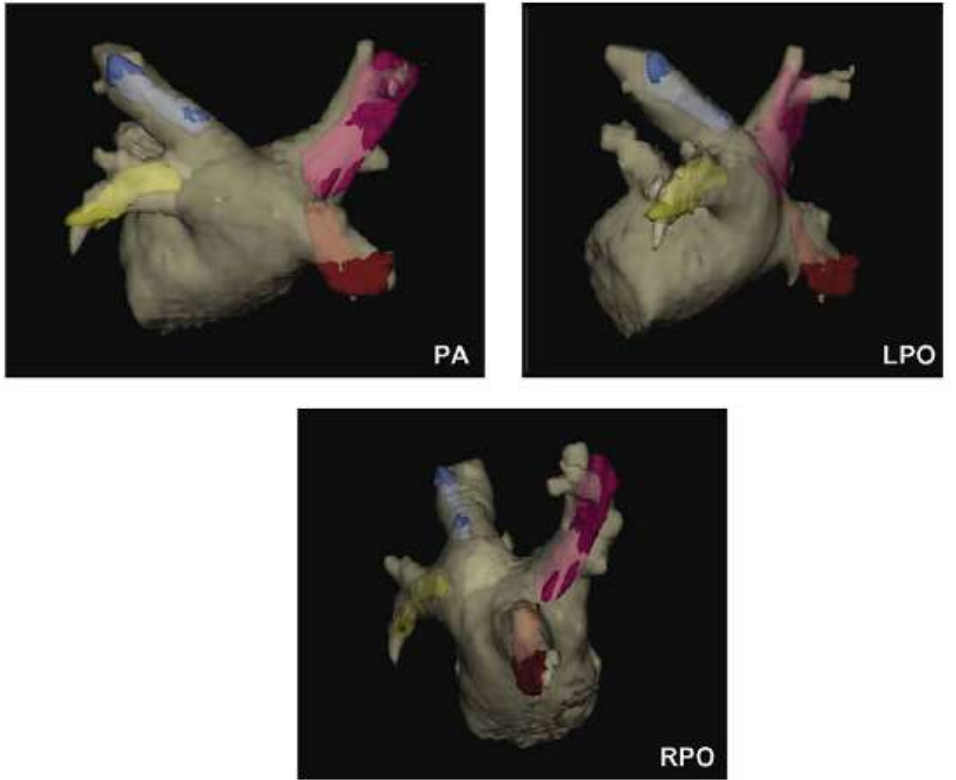

Figure 1 Main step for registering the three-dimensional computed tomography image of the left atrium into the real-time mapping system. Registration is based on reconstruction of the four pulmonary vein anatomies. (A) Pulmonary vein reconstruction was achieved through automatic anatomic point acquisition through all 10 poles of a multipolar circular mapping catheter while slowly withdrawing the catheter out of each pulmonary vein (in the picture, the left upper pulmonary vein). (B) Sync view of the four reconstructed pulmonary vein anatomies (blue, left upper pulmonary vein; yellow, left lower pulmonary vein; purple, right upper pulmonary vein; brown, right lower pulmonary vein) and the imported threedimensional computed tomography image, before registration. $(C)$ Alignment between the NavX reconstructed pulmonary vein anatomies and the pulmonary veins of the three-dimensional computed tomography image. After that main registration step, further fine adjustment was achieved through three pre-defined landmark points (left atrium roof, basal left atrium, and left atrium isthmus) visited with the ablation catheter. 


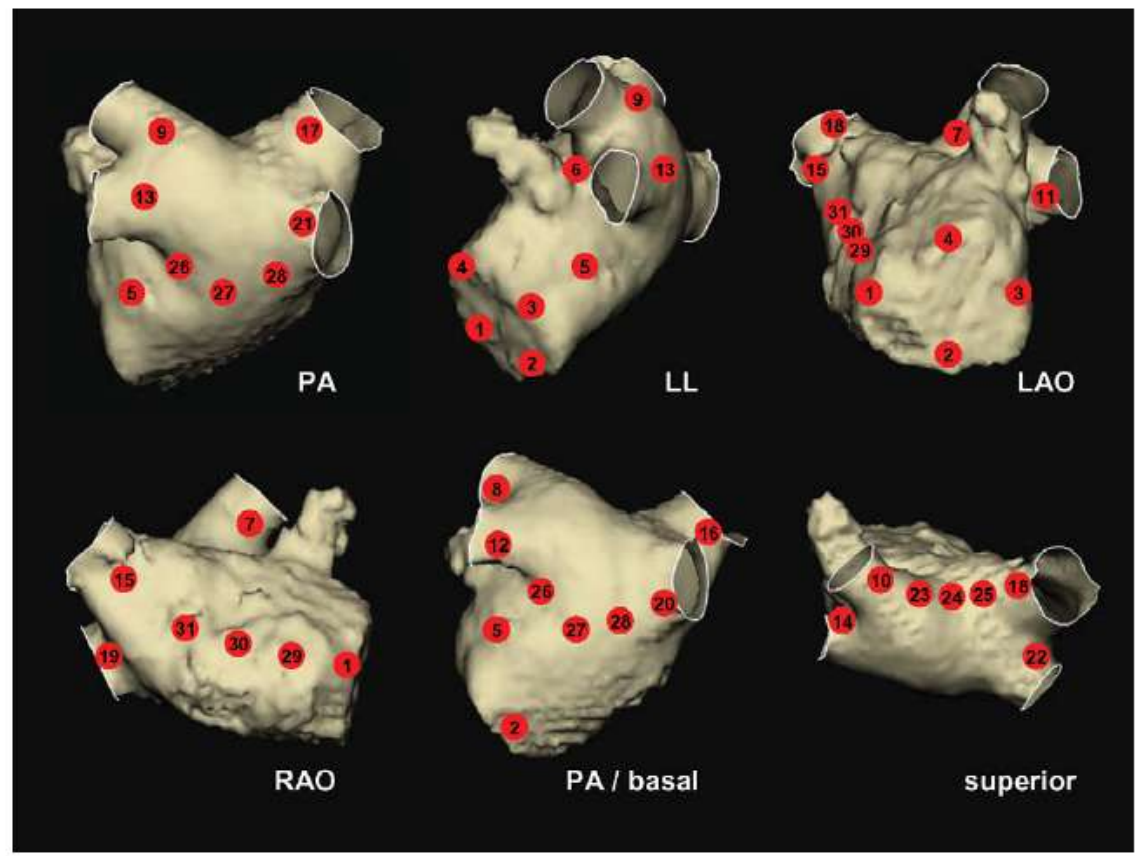

Figure 2 Control points that had to be visited with the catheter tip to assess the alignment accuracy by two independent electrophysiologists. Control point location and tissue contact were reached and assessed according to fluoroscopy information, electrogram characteristics, and tactile feedback. For each of the control points, the position of the catheter tip in relation to the registered computed tomography surface was evaluated in a nominal fashion (1-4, septal/inferior/posterior/superior mitral annulus; 5 , left atrium isthmus; 6 , tissue bridge between left atrium appendage and left upper pulmonary vein; 7-22, anterior/inferior/posterior/superior wall of each pulmonary vein; 23-25, left-sided, middle, and right-sided left atrium roof; 26-28, left-sided, middle, and right-sided basal left atrium; 29-31, annular, middle, and posterior part of the left atrium septum).

median and quartiles are given. Categorical variables are expressed as the number and percentage of patients.

\section{Results}

\section{Procedural data}

Mean procedure time as measured from the first femoral puncture to the removal of all sheaths was $187 \pm 35 \mathrm{~min}$. Registering the 3D CT into the real-time mapping system required $9 \pm 3 \mathrm{~min}$. Fluoroscopy time and RF burning time measured were $35 \pm 12$ and $47 \pm 10 \mathrm{~min}$, respectively. The irradiation dose was $13800(7200 ; 29350) \mathrm{cGy} / \mathrm{cm}^{2}$. In average, $45 \pm 13 \mathrm{RF}$ pulses were applied during the ablation.

One patient showed pericardial effusion on the post-interventional echocardiographic evaluation, which resolved after conservative treatment. Two patients developed a significant haematoma at the femoral access site without documentation of pseudoaneurysm, fistula, or deep venous thrombosis.

Table 2 displays the procedural data for the three groups of patients: paroxysmal AF, persistent $\mathrm{AF}$, and atrial MRT separately.

\section{Assessment of computed tomography alignment quality}

The assessment of the 31 LA control points revealed concordance of the registered CT surface with the true catheter tip position in $90 \%(84 \% ; 100 \%)$ of the control points. Thirteen patients had shown complete concordance of all control points between catheter tip and CT surface. The patient with the least accurate registration showed concordance in only 22 of $31(71 \%)$ control points.

The quality of CT alignment was not different between patients with a newly acquired and those with a previously acquired CT scan [90\% (81\%; 100\%) vs. $91 \%(84 \% ; 100 \%)$; $P=1.0]$. The CT alignment quality also did not differ between patients with CT imaging during SR $(n=28)$ and those with CT imaging during AF $(n=26)$ [97\% (90\%; 100\%) vs. $94 \%(84 \% ; 100 \%) ; P=0.827]$.

The control points with the highest accuracy of the registration process and concordance between catheter tip and CT surface in all 54 patients were found within the LA isthmus; at the tissue bridge between LAA and LUPV; at the posterior wall of the LUPV; at the superior and posterior wall of the LLPV; at the superior, posterior, and inferior wall of the RUPV; at the superior wall of the RLPV; along the whole LA roof; and at the left-sided and middle parts of the basal LA. The control points with the lowest accuracy of the registration process were found at the septal mitral annulus; at the anterior wall of the RUPV; and at the annular as well as the middle aspect of the LA septum; with concordance between catheter tip and CT surface in $38(70 \%), 40(74 \%), 34(63 \%)$, and $35(65 \%)$ of the 54 patients, respectively.

During ablation, the quality of the image integration process was further verified by tagging the ablation points as '3D Lesion on EnGuide', representing the true 3D anatomical position of the catheter tip and, therefore, subjectively demonstrating the presence or the absence of contact to the integrated CT surface (Figure 4). 

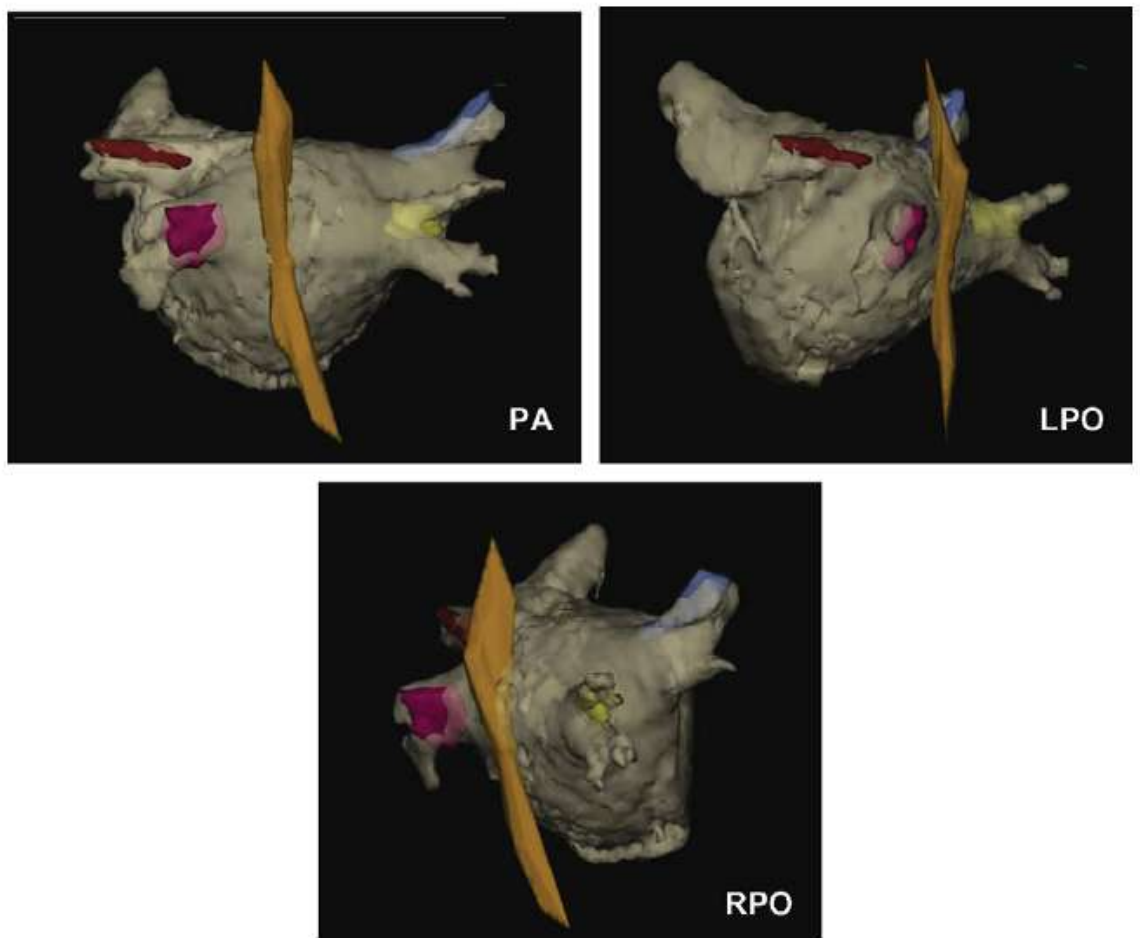

Figure 3 Following computed tomography registration and before the beginning of the ablation procedure, the oesophagus was intubated with an additional catheter, and the oesophageal anatomy was reconstructed through automatic point acquisition while slowly withdrawing the catheter out of the oesophagus. Contact and vicinity between the oesophageal anatomy reconstruction and the left atrial computed tomography anatomy was visualized. Example of a so-called B-position, where the oesophagus is positioned towards the left-sided pulmonary veins with contact at the posterior wall of the antrum of the left lower pulmonary vein (dark brown, left upper pulmonary vein; purple, left lower pulmonary vein; blue, right upper pulmonary vein; yellow, right lower pulmonary vein; light brown, oesophagus).

\section{Ablation of atrial fibrillation}

Complete isolation of the whole PV antrum for all PVs could be achieved in 35 of the 36 (97\%) patients treated for AF. In 5 of the $36(14 \%)$ patients, complete PV isolation was already found after the first placement of the circumferential ablation lines. For the remaining patients, pace and voltage mapping helped to identify and close gaps within the ablation lines. Thirty-four of the $36(94 \%)$ patients were completely isolated before the second operator analysed the result with a multipolar mapping catheter.

Among the 11 patients presenting with persistent AF, additional isolation of the posterior LA through the placement of a roof line and a line along the basal posterior LA was successfully achieved and verified through voltage and pace mapping in all 11 patients. At the end of the procedure, aggressive Burst stimulation at the atrial refractory period was able to induce AF or MRT in 5 of the 25 patients (20\%) with paroxysmal AF and 7 of the 11 patients (64\%) with persistent AF (Table 3).

\section{Ablation of atrial macro-re-entrant tachycardia}

Of the 18 patients presenting with left atrial macro-reentrant tachycardia (LAMRT), the re-entrant circuit could be found around the right lower PV $(n=3)$, around the left lower PV $(n=1)$, around the LUPV $(n=2)$, around the mitral annulus $(n=4)$, through the LA roof $(n=5)$, around the inter-atrial septum $(n=2)$, and around the LAA $(n=$ 1). The LAMRTs around the right and left PVs were successfully treated with a circumferential LA ablation line around the ipsilateral PVs isolating the whole PV antrum (Figure 5). The tachycardias through the LA roof were terminated with a roof line. The perimitral re-entrant circuits were successfully treated with an ablation line in the mitral isthmus placed from endocardially $(n=3)$ and from epicardially $(n=1)$. For the septal re-entrant circuits, a linear ablation line was placed from the right PVs to the mitral annulus. The re-entrant circuit around the LAA necessitated an ablation line from the appendage towards the superior mitral annulus. After the termination of the individual LAMRT in all 18 patients, complete isolation of all PV funnels was attempted and achieved. Fifteen out of $18(83 \%)$ patients remained non-inducible for AF and MRT on aggressive Burst stimulation at the atrial refractory period (Table 3).

\section{Follow-up}

Mean follow-up measured was $122 \pm 33$ days. In total, 8 of the 54 patients $(15 \%)$ have experienced recurrences of $\mathrm{AF}$ and/or MRT. The following recurrences of AF and/or MRT were observed for the three groups of patients presenting with paroxysmal AF, persistent $\mathrm{AF}$, and atrial MRT individually.

Two of the $18(11 \%)$ patients presenting with atrial MRT have experienced tachycardia recurrences of MRT. Three of the 25 patients (12\%) with paroxysmal AF and three of the 11 patients $(27 \%)$ with persistent $\mathrm{AF}$ have experienced recurrences of AF. 
(A)

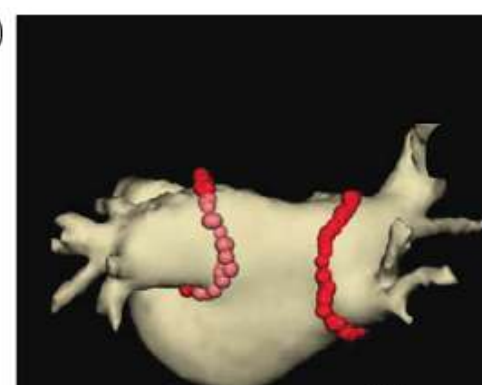

PA

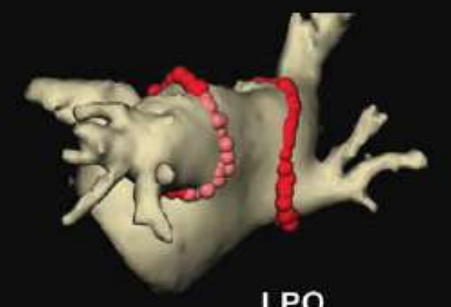

LPO

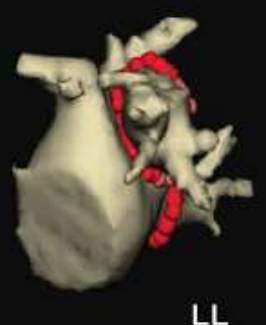

LL

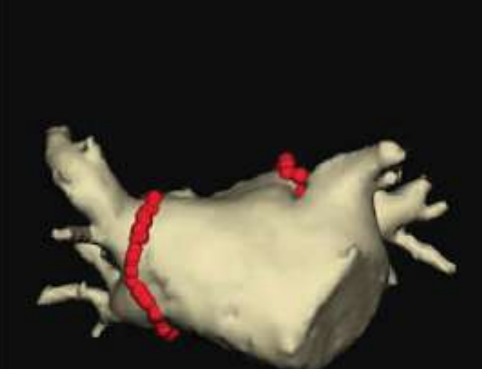

RAO

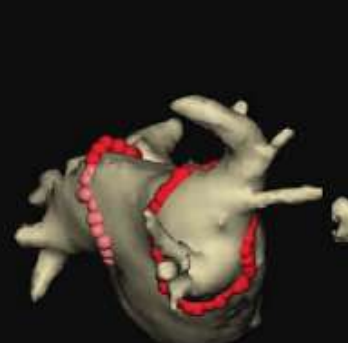

RL

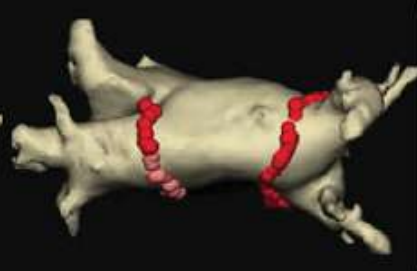

superior

(B)
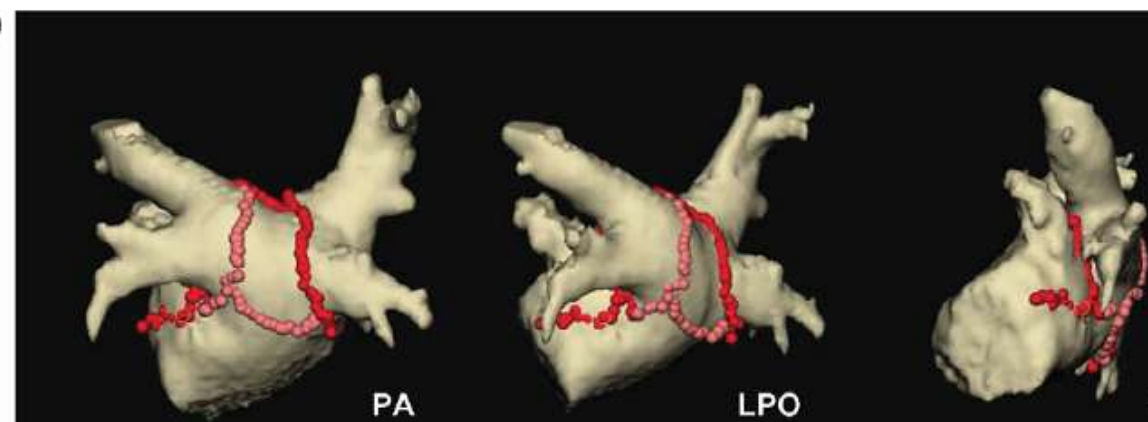

LL

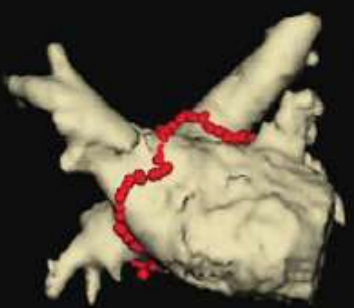

RAO

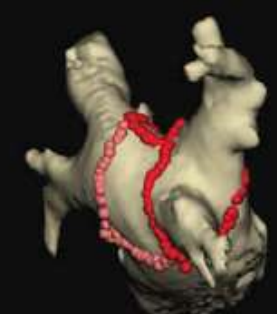

RL

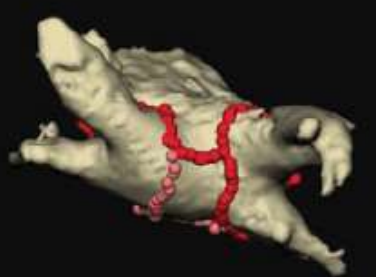

superior

Figure 4 Left atrial ablation procedures in patients presenting with paroxysmal and persistent atrial fibrillation. Ablation points were marked as 'three-dimensional Lesion on EnGuide' (red-coloured lesion points), which documents the true three-dimensional localization of the catheter tip (no projection on computed tomography surface and no 'Lesion at Mouse'). The true position of the catheter tip on the computed tomography surface can be appreciated for all ablation target areas, underlining the registration accuracy. Pink-coloured lesion points represent ablation in areas with oesophageal vicinity (energy reduction to $30 \mathrm{~W}$ and shorter ablation duration). (A) Example of a patient with paroxysmal atrial fibrillation. Circumferential left atrial lesions were deployed around the funnels of the left- and right-sided pulmonary veins. As an anatomical variation, this patient presented with a common funnel of the left-sided pulmonary veins. $(B)$ Example of a patient with persistent atrial fibrillation. After circumferential left atrial ablation, additional linear ablation lines were placed in the left atrium for further substrate modification (left atrium roof, left atrium isthmus, and posterior basal left atrium). The resulting 'box-lesion' at the posterior left atrium was completely isolated using voltage and pace mapping criteria. 


\section{Discussion}

\section{Main findings of the study}

In a population of patients presenting with paroxysmal AF, persistent AF, and atrial MRT, our study shows the feasibility

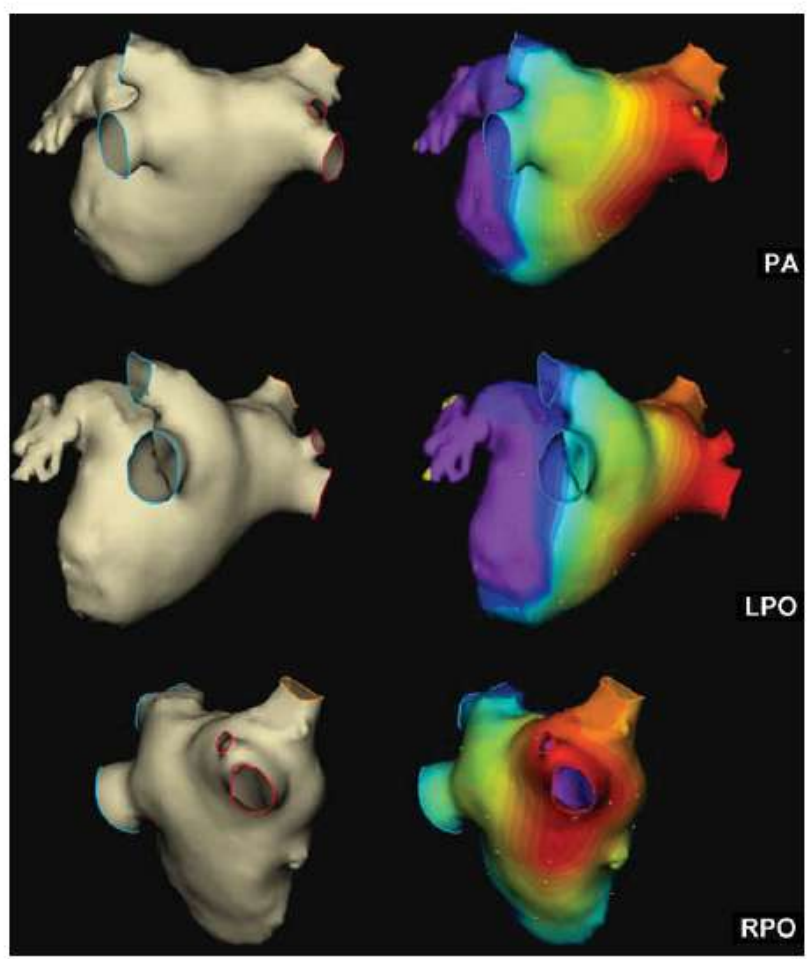

Figure 5 Example of a patient with a left atrial macro-re-entrant tachycardia. The left panel shows the pure three-dimensional computed tomography anatomy after registration. The NavX reconstructed pulmonary veins are hidden. The distal part of each pulmonary vein is cut off for image clarity. Locations within the computed tomography anatomy were visited with the ablation catheter. In stable catheter positions (small yellow points), entrainment mapping was performed. The right panel illustrates the colourcoded entrainment information in a three-dimensional fashion. Red colours representing areas with a short return cycle (close to the re-entrant circuit) and purple colours representing areas with a long return cycle (far away from the re-entrant circuit). 'Isochronal lines' connect locations with a similar length of the return cycle. The map clearly shows a macro-re-entrant circuit around the right lower pulmonary vein. Circumferential ablation around the antrum of the right-sided pulmonary veins teminated the tachycardia. of successful placement of different complex linear ablation line concepts guided by an integrated 3D image anatomy alone, rather than catheter-based virtual atrial chamber reconstructions.

\section{Benefits and limitations of image integration}

The catheter ablation of complex atrial arrhythmias requires accurate knowledge of the true cardiac anatomy of the respective patient for the placement of either purely anatomically defined sets of ablation lines such as in those with $\mathrm{AF}$ or the understanding of the true 3D spread of electrical activation throughout the cardiac anatomy with subsequent design and placement of respective ablation lesions such as in patients with atrial MRT. Following that principle idea, the concept of image integration has been developed, superimposing pre-acquired 3D CT/MRI images onto the EAM chamber surface reconstruction in order to add more detailed anatomical orientation. Despite having shown clinical benefit with a higher rate of ablation success, current techniques of image integration do have limitations..$^{7-9}$ So far, registration of the pre-acquired $3 \mathrm{D}$ image into the real-time mapping system can be achieved with two different registration modalities-landmark and surface registration. Landmark registration is based on the alignment of distinct stable and easily accessible 3D points between the EAM surface reconstruction and their assumed position on the $3 \mathrm{D}$ image. For surface registration, all 3D points of the EAM surface reconstruction are attached to the closest possible CT surface. Previous studies have shown limitations for each of the two registration modalities. ${ }^{10,11}$ Landmark registration ultimately depends on the quality of the individual landmark. Several landmarks such as aortic arch, coronary sinus, caval veins, or different LA locations have been suggested; however, registration points at the posterior PV-LA junction have resulted in the least registration error. ${ }^{11}$ After all, although landmark registration could adequately delineate specific anatomical regions, it could not guarantee a good global fit, measured as the average distance between all 3D EAM points and the closest 3D image surface location. Surface registration, in contrast, could achieve a better global registration result; however, applying that algorithm shifted map and image significantly, dislocated well-aligned landmarks at the posterior PV-LA junction, and resulted in significant registration inaccuracies especially in target areas for circumferential PV ablation. ${ }^{11}$ One reason for these limitations can be seen in the quality of the 3D EAM surface reconstruction, which in

Table 2 Ablation characteristics

\begin{tabular}{llll}
\hline & Paroxysmal AF $(n=25)$ & Persistent AF $(n=11)$ & MRT $(n=18)$ \\
\hline Mean procedure time $(\min )^{\mathrm{a}}$ & $188 \pm 40$ & $195 \pm 45$ & $205 \pm 21$ \\
${\text { Mean fluoroscopy time }(\mathrm{min})^{\mathrm{a}}}_{\text {Iradiation dose }\left(\mathrm{cGy} / \mathrm{cm}^{2}\right)^{\mathrm{b}}}$ & $34 \pm 9$ & $45 \pm 17$ & $43 \pm 12$ \\
RF burning time $(\mathrm{min})^{\mathrm{b}}$ & $13800(11100 ; 23900)$ & $16200(7100 ; 33300)$ & $15300(11900 ; 34000)$ \\
Number of RF pulses & $53(35 ; 59)$ & $61(47 ; 84)$ & $44(31 ; 52)$ \\
RF energy $(\mathrm{J})^{\mathrm{b}}$ & $46(30 ; 60)$ & $43(38 ; 69)$ & $37(26 ; 44)$ \\
\hline
\end{tabular}

$\mathrm{AF}$, atrial fibrillation; MRT, macro-re-entrant tachycardia; RF, radiofrequency.

aData given as mean and standard deviation.

bData given as median and quartiles. 
Table 3 Procedural and clinical outcome

\begin{tabular}{lccc}
\hline & Paroxysmal AF $(n=25)$ & Persistent AF $(n=11)$ & MRT $(n=18)$ \\
\hline Re-entrant pathway & - & \multicolumn{1}{c}{ Perimitral (4) } \\
LA roof (5) & Around PV (6) \\
& & Septal (2) & Around LAA (1) \\
& & & $18(100)$ \\
Complete PV isolation, $n(\%)$ & $24(96)$ & $11(100)$ & $3(17)$ \\
AF/MRT inducibility, $n(\%)$ & $5(20)$ & $3(27)$ & $2(11)$ \\
AF/MRT recurrences, $n(\%)$ & $3(12)$ & & \\
\hline
\end{tabular}

AF, atrial fibrillation; MRT, macro-re-entrant tachycardia; LA, left atrium; PV, pulmonary vein; LAA, left atrial appendage.

itself can be anatomically misleading due to indentation of the LA wall and inadequate point collection in areas with difficult catheter access. Variations in LA size and LA anatomy due to differences in LA filling and cardiac rhythm carry further uncertainties. Owing to these limitations so far, image integration has only been used as an adjunct to conventional 3D EAM, and in questionable situations has simply been disregarded.

\section{Image integration in the present study}

Our study is the first one to report the placement of complex $3 \mathrm{D}$ ablation lines directly within an atrial 3D image without EAM surface reconstruction for the treatment of a larger group of patients presenting with AF and atrial MRT. Given their stable position fixated in the posterior mediastinum, the PVs served as the main registration structure (Figure 1).

Thirty-one pre-defined control points in the LA and at the LA-PV junction served for the assessment of the alignment quality and revealed a high accuracy of the registration process (Figure 2). Among all 54 patients in 90\% (84\%; $100 \%$ ) of the control points, concordance between fluoroscopy/electrogram/tactile-guided catheter tip position and surface contact on the integrated CT image could be found. In 13 patients, all control points were imaged accurately. The highest percentage of concordance was found at the control points covering the posterior aspect of LA and PVs. The lowest percentage of concordance was found at the control points of the LA septum and anterior to the right upper PV. The fixation of the heart through the posterior LA and the PVs at the posterior mediastinum can be seen as a reason for the observed distribution of control points with higher and lower registration accuracy. The position of the posterior LA and the PVs is very stable and reproducible, which incidentally suits the purpose of AF ablation line placement. In contrast, the mitral annulus and the LA septum are much more mobile and sensitive towards changes in LA filling and cardiac rhythm, which, however, is less relevant from the point of $\mathrm{AF}$ catheter ablation. Optimal catheter access to all pre-defined control points and the quality of $\mathrm{CT}$ segmentation and $3 \mathrm{D} \mathrm{CT}$ reconstruction may constitute further reasons for observed alignment inaccuracies in the mentioned areas. Clinically, in all 54 patients, the ablation procedure could be finished successfully within the CT image, and no additional atrial chamber reconstruction was required. The registration accuracy was further underlined by tagging of the ablation points as '3D Lesion on EnGuide', which technically does not represent a catheter tip projection onto the CT surface, but a true 3D position of the catheter tip revealing the presence or the absence of surface contact to the CT image (Figure 4).

In our approach, we did not use the Ensite Field scaling algorithm to compensate for inhomogenities in the transthoracic electrical fields. Indeed, in order to apply the field scaling algorithm, one has to first reconstruct the 3D geometry of the chamber being mapped so that the electrical field inhomogenities can be detected by non-linearities in the detected inter-electrode distances of the roving catheter. Our approach, in which the chamber is not reconstructed, therefore, does not allow the field scaling algorithm to be applied. Although the application of field scaling could lead to more accurate image integration, ${ }^{12}$ we found our approach to be of sufficient accuracy for clinical use. Further, prospective clinical research work concerning not only the PV isolation but also the ablation of intra-atrial targets should further determine the clinical usefulness of this approach.

\section{Patient population, procedural, and clinical outcome}

Our study population included a consecutive group of patients presenting for catheter interventional treatment of AF and atrial MRT. Among them, the patients with persistent AF showed a significantly enlarged LA $(53 \pm 6 \mathrm{~mm})$. Furthermore, 11 patients had experienced previous cardiac surgery and six patients presented with a common antrum of the left-sided PVs (Figure 4A).

This cohort of patients with variable and partially altered atrial anatomies presenting with different types of complex atrial arrhythmias rather constitutes a challenge for the interventional electrophysiologist. However, in all patients, it was possible to plan and perform the required lesion line concept within the anatomy of the registered 3D image without atrial chamber reconstruction.

In all 54 patients complete isolation of all PVs was attempted. In patients with AF that was the primary therapeutical target. In patients with MRT, the primary therapeutical target was to map, and ablate the MRT, but afterwards as a secondary therapeutical target the PVs were also isolated in those patients. In 53 of the 54 (98\%) patients, complete isolation was achieved and verified through bidirectional block on a circular multipolar mapping catheter placed by a second electrophysiologist who was not involved in the ablation part of the procedure. 
On a follow-up based on a serial 7-day-Holter ECG including the analysis of more than $27000 \mathrm{~h}$ of ECG recording, the clinical outcome showed $88 \%$ freedom from AF and/or MRT in patients presenting with paroxysmal AF. In patients with persistent $A F$, the success rate (freedom from $A F$ and/or MRT) after a single LA intervention measured $73 \%$. Sixteen of $18(89 \%)$ patients presenting with atrial MRT remained free of $A F$ and/or MRT during follow-up.

\section{Limitation of the study}

Our study, although being prospective in nature, represents a non-randomized single-centre experience. The current follow-up period does not allow a final judgement on longterm clinical benefit; however, the main purpose of the study was to analyse procedural aspects with a clear electrophysiologically defined procedural endpoint.

The assessment of the accuracy of $3 D$ image integration in vivo is difficult, given a moving organ, a breathing patient, and a static image. Imaging modalities such as MRI or intra-cardiac echo lack spatial resolution or 3D orientation to provide an accurate in vivo assessment of $3 \mathrm{D}$ image integration accuracy. We therefore took a very clinical approach and validated the position of the tip of the catheter within the integrated $\mathrm{CT}$ image against our judgement on catheter tip position derived from fluoroscopy, local electrogram, and tactile information. This is a rough and non-quantitative assessment. However, performed for 31 different points throughout the LA and the PV individually, it does give a good impression as to whether the registration is accurate and the catheter appears in the CT where we would expect it to or whether this is not the case.

Furthermore, potential inaccuracies in the control point analysis result from changes in LA filling, cardiac cycle length, and respiratory motion.

\section{Clinical implications}

Our study describes practical image integration in one of the most widely used electro-anatomical mapping systems, NavX-Ensite. Utilizing this tool, feasibility of successful placement of different complex linear ablation line concepts guided by an integrated 3D image anatomy alone, rather than catheter-based virtual chamber reconstructions, has been shown in a heterogeneous group of patients presenting with a variety of atrial anatomies and clinical arrhythmias.

Following the principle idea, that a 3D reconstructed imaging technology provides higher anatomical accuracy when compared with any virtual point-by-point EAM surface reconstruction, our data are part of the first steps to develop approaches, in which electrophysiological analysis, therapy planning, and ablation can be performed within realistic 3D cardiac chamber anatomies. Currently, CT scan radiation exposures and off-line $\mathrm{CT}$ segmentation represent limitations for that concept. However, 3D images acquired on-line during the EP procedure (through either rotation angiography or even echocardiography), and immediately exported into the real-time mapping system, may develop into simple tools to overcome these limitations.

Conflict of interest: none declared.

\section{Funding}

Funding to pay the Open Access publication charges for this article was provided by Hospital resources.

\section{References}

1. Ben-Haim SA, Osadchy D, Schuster I, Hayam G, Josephson ME. Nonfluoroscopic, in vivo navigation and mapping technology. Nat Med 1996;2: 1393-5.

2. Krum D, Goel A, Hauck J, Schweitzer J, Hare J, Attari M et al. Catheter location, tracking, cardiac chamber geometry creation, and ablation using cutaneous patches. J Interv Card Electrophysiol 2005;12:17-22.

3. Piorkowski C, Hindricks G, Schreiber D, Tanner H, Weise W, Koch A et al. Electroanatomic reconstruction of the left atrium, pulmonary veins, and esophagus compared with the 'true anatomy' on multislice computed tomography in patients undergoing catheter ablation of atrial fibrillation. Heart Rhythm 2006;3:317-27.

4. Dong J, Dickfeld T, Dalal D, Cheema A, Vasamreddy CR, Henrikson CA et al. Initial experience in the use of integrated electroanatomic mapping with three-dimensional MR/CT images to guide catheter ablation of atrial fibrillation. J Cardiovasc Electrophysiol 2006;17:459-66.

5. Kistler PM, Rajappan K, Jahngir M, Earley MJ, Harris S, Abrams D et al. The impact of CT image integration into an electroanatomic mapping system on clinical outcomes of catheter ablation of atrial fibrillation. J Cardiovasc Electrophysiol 2006;17:1093-101.

6. Shalganov TN, Vatasescu R, Paprika D, Kornyei L, Vanyi J, Geller L et al. A simple algorithm for defining the mechanism and the chamber of origin in atrial tachycardias. J Electrocardiol 2006;39:369-76.

7. Kottkamp H, Piorkowski C, Tanner H, Kobza R, Dorszewski A, Schirdewahn $\mathrm{P}$ et al. Topographic variability of the esophageal left atrial relation influencing ablation lines in patients with atrial fibrillation. $J$ Cardiovasc Electrophysiol 2005; 16:146-50.

8. Heist EK, Chevalier J, Holmvang G, Singh JP, Ellinor PT, Milan DJ et al. Factors affecting error in integration of electroanatomic mapping with $\mathrm{CT}$ and MR imaging during catheter ablation of atrial fibrillation. $J$ Interv Card Electrophysiol 2006;17:21-7.

9. Ferguson J. Optimizing catheter navigation for AF ablation: do not just follow the map!. J Cardiovasc Electrophysiol 2007;18:283-5.

10. Zhong $\mathrm{H}$, Lacomis JM, Schwartzman D. On the accuracy of CartoMerge for guiding posterior left atrial ablation in man. Heart Rhythm 2007;4: 595-602.

11. Fahmy TS, Mlcochova $H$, Wazni $O M$, Patel $D$, Cihak $R$, Kanj $M$ et al. Intracardiac echo-guided image integration: optimizing strategies for registration. J Cardiovasc Electrophysiol 2007;18:276-82.

12. Brooks AG, Wilson L, Kuklik P, Stiles MK, John B, Hany Dimitri S et al. Image integration using NavX Fusion: initial experience and validation. Heart Rhythm 2008;5:526-35. 


\subsection{Entwicklungen der Bildintegration und einer Modell-gestützten Therapie}

4.1.3. Farb-kodiertes dreidimensionales „Entrainment Mapping“ zur Analyse und Therapie von atrialen Makro-Reentry-Tachykardien

Zitierweise:

Masahiro Esato, MD, Gerhard Hindricks, MD, PhD, Philipp Sommer, MD, Arash Arya, MD, Thomas Gaspar, MD, Kerstin Bode, MD, Andreas Bollmann, MD, PhD, Ulrike Wetzel, MD, Sebastian Hilbert, MD, Simon Kircher, MD, Charlotte Eitel, MD, Christopher Piorkowski, MD.

Color-coded three-dimensional entrainment mapping for analysis and treatment of atrial macroreentrant tachycardia.

Heart Rhythm 2009;6:349 -358. 


\title{
Color-coded three-dimensional entrainment mapping for analysis and treatment of atrial macroreentrant tachycardia
}

\author{
Masahiro Esato, MD, Gerhard Hindricks, MD, PhD, Philipp Sommer, MD, Arash Arya, MD, \\ Thomas Gaspar, MD, Kerstin Bode, MD, Andreas Bollmann, MD, PhD, Ulrike Wetzel, MD, \\ Sebastian Hilbert, MD, Simon Kircher, MD, Charlotte Eitel, MD, Christopher Piorkowski, MD \\ From the University of Leipzig-Heart Center, Leipzig, Germany.
}

BACKGROUND Mapping and ablation of atrial macroreentrant tachycardia focus on activation mapping with identification of the area of slow conduction.

OBJECTIVE The purpose of this study was to evaluate a new concept for analysis and treatment of macroreentrant tachycardia based on color-coded three-dimensional (3D) entrainment mapping and subsequent placement of strategic lesion lines.

METHODS Twenty-six patients presented with macroreentrant tachycardia (cycle length $329 \pm 70 \mathrm{~ms}$ ). Using nonfluoroscopic systems (CARTO 12, NavX 14), sequential mapping of the target atrium was performed. On each mapping point, the $3 \mathrm{D}$ location was paired with color-coded entrainment information so that the reentrant circuit could be directly visualized.

RESULTS Procedural duration, fluoroscopy time, and radiofrequency time measured $181 \pm 58,37 \pm 19$, and $31 \pm 17$ minutes, respectively. Thirty-nine macroreentrant tachycardias were ablated: perimitral 9, around pulmonary vein ostium 6 , through left atrial roof 5, around left atrial appendage 3 , right atrial cavotricuspid isthmus dependent 6 , around right atrial scar 2, around superior vena cava 1 , within the septum 5 , and within the coronary sinus 2. Tachycardia termination and noninducibility of any macroreentrant tachycardia was the procedural end-point. In case of left atrial macroreentrant tachycardia, pulmonary vein isolation was completed. Follow-up with serial 7-day Holter covered $302 \pm$ 82 days. Two ( $8 \%$ ) patients experienced recurrences of a pretreated macroreentrant tachycardia.

CONCLUSION In patients with macroreentrant tachycardia, colorcoded 3D entrainment mapping is feasible to accurately determine and visualize the $3 D$ location of the reentrant circuit and to plan a strategic ablation line concept. That approach, not targeting the area of slow conduction of the circuit, resulted in excellent procedural success $(100 \%)$, with long-term freedom from any tachycardia recurrences in $88 \%$ of patients.

KEYWORDS Entrainment mapping Activation mapping; Atrial macroreentrant tachycardia; Three-dimensional mapping system; Color coding; Strategic ablation lines

(Heart Rhythm 2009;6:349-358) 2009 Heart Rhythm Society. All rights reserved.

\section{Introduction}

Atrial macroreentrant tachycardia is a common arrhythmia following catheter interventional and surgical ablation of atrial fibrillation (AF). ${ }^{1}$ An accurate understanding of the anatomic location of the reentrant pathway is crucial for curative ablation of the arrhythmia.

Currently, sequential activation mapping supported by three-dimensional (3D) electroanatomic mapping systems is widely used to reconstruct the 3D spread of electrical activation throughout cardiac chamber anatomies. Generation of complete activation maps precise enough to detect the critical isthmus of the tachycardia (1) is challenging because correct annotation of electrograms within the reentrant circuit is difficult and requires experience, (2) is time consuming, and (3) requires stability of the reentrant circuit. Following previous ablation procedures such as AF ablation of

\footnotetext{
Address reprint requests and correspondence: Dr. Christopher Piorkowski, University of Leipzig, Heart Center, Department of Electrophysiology, Strümpellstrasse 39, 04289 Leipzig/Germany. E-mail address: cp7026@yahoo.de. (Received October 17, 2008; accepted December 3, 2008.)
}

electrically diseased atria with discontinuous ablation lines, diffuse scar areas and subsequent multiple conduction delay further impede allocation of the appropriate local activation time and limit the ability to determine the true nature of the reentrant circuit and the success rate of ablation. ${ }^{1}$

Entrainment stimulation with measurement of the postpacing interval (PPI) describes the distance of the local catheter tip position from the actual reentrant circuit, with equality of PPI and tachycardia cycle length (TCL) exactly within the reentrant circuit. $^{2-5}$

In this prospective study, we evaluated a new approach for mapping and ablation of macroreentrant tachycardia based on direct visualization of the reentrant circuit through 3D color-coded entrainment mapping and subsequent strategic lesion line placement.

\section{Methods}

\section{Patient characteristics}

Between May 2007 and February 2008, 26 patients (20 men and 6 women; mean age $59 \pm 12$ years) presented for 
Table 1 Patient and arrhythmia characteristics

\begin{tabular}{|c|c|c|c|c|c|c|c|}
\hline \multirow[b]{2}{*}{$\mathrm{N}$} & \multirow[b]{2}{*}{ Age (years)/gender } & \multirow[b]{2}{*}{ Ejection fraction $(\%)$} & \multirow[b]{2}{*}{ Heart disease/prior surgery } & \multirow[b]{2}{*}{ Prior ablation } & \multicolumn{3}{|c|}{$\begin{array}{l}\text { Treated macroreentrant } \\
\text { tachycardia }\end{array}$} \\
\hline & & & & & $\mathrm{CL}$ (ms) & Mechanism & Gap* \\
\hline 1 & $74 / \mathrm{M}$ & 54 & CAD/bypass, cryo & CPVA, CTI & 330 & Around PV & Yes \\
\hline 2 & $42 / \mathrm{M}$ & 60 & - & CPVA, MA, roof, CTI & 300 & Around PV & Yes \\
\hline \multirow[t]{2}{*}{3} & $71 / \mathrm{M}$ & 65 & HT & CPVA & 370 & Perimitral & No \\
\hline & & & & & 380 & CTI & No \\
\hline \multirow[t]{2}{*}{4} & $58 / \mathrm{M}$ & 51 & CAD, HT/bypass, cryo & CPVA, CTI & 300 & CTI & Yes \\
\hline & & & & & 340 & Within CS & No \\
\hline 5 & $41 / \mathrm{M}$ & 25 & DCM & CPVA, MA, roof, CTI & 240 & Within CS & No \\
\hline 6 & $64 / M$ & 60 & HT & CPVA & 330 & Around PV & Yes \\
\hline 7 & $52 / M$ & 65 & - & CPVA, CTI & 320 & Around LAA & No \\
\hline \multirow[t]{2}{*}{8} & $47 / M$ & 65 & HT & CPVA, MA, roof, & 460 & Perimitral & Yes \\
\hline & & & & septal, CTI & 370 & Septal & Yes \\
\hline 9 & $67 / \mathrm{M}$ & 61 & - & CPVA, CTI & 260 & Around PV & Yes \\
\hline 10 & $74 / \mathrm{M}$ & 50 & Mitral valve disease/mechanical MVR & CTI & 270 & LA roof & No \\
\hline 11 & $38 / M$ & 59 & Sinus venous defect/ASD closure & CTI & 380 & Around SVC & No \\
\hline 12 & 49/M & 25 & DCM & CPVA, MA, roof, CTI & 300 & LA roof & Yes \\
\hline 13 & $71 / \mathrm{M}$ & 50 & Mitral valve disease/MV reconstruction & CTI & 300 & Around LAA & No \\
\hline \multirow[t]{3}{*}{14} & $62 / M$ & 60 & Mitral valve disease/mechanical MVR & - & 250 & LA roof & No \\
\hline & & & & & 330 & Perimitral & No \\
\hline & & & & & 300 & Septal & No \\
\hline \multirow[t]{2}{*}{15} & $59 / \mathrm{F}$ & 70 & HNCM & CPVA, MA, roof, CTI & 430 & Septal & No \\
\hline & & & & & 460 & Perimitral & Yes \\
\hline \multirow[t]{2}{*}{16} & $65 / M$ & 65 & - & CPVA, MA, roof & 240 & Perimitral & Yes \\
\hline & & & & & 310 & LA roof & Yes \\
\hline 17 & $73 / \mathrm{F}$ & 65 & HT & CPVA, MA, roof, CTI & 290 & Perimitral & Yes \\
\hline \multirow[t]{2}{*}{18} & $70 / \mathrm{F}$ & 55 & HT & CPVA, MA; roof, CTI & 360 & Septal & No \\
\hline & & & & & 520 & CTI & Yes \\
\hline \multirow[t]{2}{*}{19} & $62 / \mathrm{F}$ & 65 & HT & CPVA & 260 & LA roof & No \\
\hline & & & & & 260 & Perimitral & No \\
\hline 20 & $33 / \mathrm{F}$ & 70 & Mitral valve disease/reconstruction, cryo & CPVA & 280 & Around PV & Yes \\
\hline 21 & $72 / \mathrm{F}$ & 35 & $\mathrm{CAD}, \mathrm{HT}$ & - & 310 & Perimitral & No \\
\hline \multirow[t]{2}{*}{22} & $67 / \mathrm{M}$ & 47 & Mitral valve disease/mechanical MVR, cryo & CPVA & 340 & RA scar & No \\
\hline & & & & & 370 & $\mathrm{CTI}$ & No \\
\hline 23 & $49 / M$ & 62 & HT & CPVA, MA, roof, CTI & 270 & Around LAA & No \\
\hline \multirow[t]{2}{*}{24} & $57 / \mathrm{F}$ & 65 & ASD II/ASD closure & - & 440 & CTI & No \\
\hline & & & & & 400 & RA scar & No \\
\hline \multirow[t]{3}{*}{25} & $73 / \mathrm{M}$ & 53 & CAD, HT/bypass & - & 230 & Septal & No \\
\hline & & & & & 240 & CTI & No \\
\hline & & & & & 330 & Perimitral & No \\
\hline 26 & $56 / M$ & 60 & - & CPVA, MA, roof, CTI & 270 & Around PV & Yes \\
\hline
\end{tabular}

$A S D=$ atrial septal defect; $C A D=$ coronary artery disease; $C P V A=$ circumferential $P V$ ablation; $c r y o=$ intraoperative cryoablation; $C S=$ coronary sinus; $\mathrm{CTI}=$ right atrial cavotricuspid isthmus; $\mathrm{DCM}=$ dilated cardiomyopathy; $\mathrm{HNCM}=$ hypertrophic nonobstructive cardiomyopathy; $\mathrm{HT}=$ arterial hypertension; $L A=$ left atrium; $L A A=$ left atrial appendage; $M A=$ mitral isthmus line; $M V R=$ mitral valve replacement; $P V=$ pulmonary vein; $R A=$ right atrium; roof = left atrial roof line; SVC = superior vena cava.

*Suspected gap-related mechanism.

catheter interventional treatment of symptomatic macroreentrant tachycardia (CL $329 \pm 70 \mathrm{~ms}$ ) uncontrolled by repetitive electrical cardioversions and subsequent antiarrhythmic drug treatment. Patients presenting with a high likelihood for a typical right atrial (RA) isthmus-dependent flutter (typical P-wave morphology on 12-lead surface ECG and no previous AF ablation procedures) were not included in the study.

Thirteen $(50 \%)$ patients had received an unsuccessful trial of amiodarone therapy. There was no weaning-out period. The antiarrhythmic drug was discontinued on the day the patient entered the hospital for the ablation procedure. Organic heart disease was present in $14(54 \%)$ patients (coronary artery disease 4 , valvular heart disease 5 , dilated cardiomyopathy 2 , hypertrophic cardiomyopathy 1 , atrial septal defect 2 ), and $11(42 \%)$ patients had a history of arterial hypertension. Ten (38\%) patients had previously undergone cardiovascular surgery (coronary artery bypass 3 , mechanical mitral valve replacement 3 , mitral valve reconstruction 2, atrial septal defect closure 2). Five (19\%) patients had so-called lone arrhythmia without any structural heart disease. Mean left ventricular ejection fraction measured $56 \% \pm 12 \%$, and mean left atrial (LA) diameter measured $45 \pm 5 \mathrm{~mm}$. Prior attempts at AF ablation had been performed in $19(73 \%)$ patients (catheter interventional circumferential pulmonary vein [PV] ablation with radiofrequency energy 15 , intraoperative circumferential PV ablation with cryoenergy 4). Prior cavotricuspid isthmus ablation for typical atrial flutter had been performed in $16(62 \%)$ patients. The individual characteristics of the 26 patients are given in Table 1 


\section{Electrophysiologic study}

Prior to the procedure, transesophageal echocardiography was performed to exclude thrombus formation within the LA. Patients were studied under deep propofol sedation with continuous invasive monitoring of arterial blood pressure and oxygen saturation. Standard catheters were placed in the right ventricular apex and coronary sinus (CS). For patients who presented in sinus rhythm at the beginning of the procedure (no. $4,11,15$ ), burst stimulation at the atrial refractory period was applied to induce the macroreentrant tachycardia.

In all patients, initial entrainment mapping within the high RA, RA isthmus, and CS was used to distinguish an RA or LA origin of the macroreentrant circuit. ${ }^{6}$ In patients with a suspected LA macroreentrant tachycardia, a single transseptal puncture performed under fluoroscopic guidance provided access into the LA, and repeated doses of heparin were administered to maintain an activated clotting time of 250 to 300 seconds throughout the procedure. Catheter navigation was performed with steerable sheath technology in all patients (Agilis, St. Jude Medical, Inc., St. Paul, MN, USA). $^{7}$

\section{Concept of color-coded 3D entrainment mapping}

Sequential mapping of the suspected chamber of origin was performed using either CARTO (Biosense Webster, Inc., Diamond Bar, CA, USA) or NavX ((Endocardial Solutions, Inc., St. Paul, MN, USA) as the electroanatomic mapping system. At each mapping point, entrainment stimulation at a pacing rate $30 \mathrm{~ms}$ below the TCL was applied through the tip of the ablation catheter with an output of $7.5 \mathrm{~V} / 1.5 \mathrm{~ms}$. PPI, which was defined as the time interval from the last pacing artifact to the first local atrial electrogram recorded from the tip of the ablation catheter, was measured using an EP recording system (Prucka CardioLab, Prucka Engineering, Houston, TX, USA). ${ }^{3,8,9}$ Activation sequence and CL of the atrial electrogram recorded from the CS catheter during entrainment stimulation were used to ensure atrial capture.

At each mapping point, the time difference between PPI and TCL was calculated and stored together with the 3D anatomic position on the electroanatomic mapping system in a color-coded fashion. Because neither of the electroanatomic mapping systems (CARTO, NavX) contains an algorithm for color coding of entrainment information, the modus for activation mapping was altered manually as follows. The 3D location of the catheter tip was stored on the electroanatomic mapping system. At this position, entrainment stimulation was performed through the conventional EP system. The difference between PPI and TCL was calculated and plugged into the electroanatomic mapping system (as if it would be an "activation time"). For that, the local electrogram stored at the 3D location was completely disregarded. The annotation marker was manually moved into a position where the numeric timing information equaled the entrainment information (PPI-TCL) as obtained from the EP system. That timing information then was displayed in a color-coded fashion as if it were an activation time, but in fact it represented information on the length of the entrainment return cycle. We manually adapted the color bar such that points with return cycles more than $100 \mathrm{~ms}$ longer than the TCL were blanked out in purple because they are far away from the reentrant circuit. In this way, the entire color bar (from red to blue) encoded 3D points with return cycles less than $100 \mathrm{~ms}$ longer than the TCL in a continuous fashion. With that set of range, red represents points closest to the reentrant circuit with PPI between approximately 0 to $30 \mathrm{~ms}$ above the TCL. Figure 1 illustrates the concept of color-coded 3D entrainment mapping.

Mapping points with unsuccessful entrainment and lack of local bipolar potential were annotated as scar. In mapping points with unsuccessful entrainment despite a good electrical signal, first catheter contact was increased mechanically. If entrainment still was unsuccessful, that position was not stored/annotated, and entrainment was repeated with the catheter tip moved a few millimeters over. None of the patients had a larger endocardial area with failure to entrain despite a good electrical signal and good contact.

Typical activation mapping with measurement and recording of local activation times was not used in any of the study patients.

\section{CART0-based mapping procedures}

In $12(46 \%)$ patients, CARTO was used as the electroanatomic mapping system for nonfluoroscopic 3D catheter orientation, color-coded 3D visualization of the entrainment information, and tagging of ablation sites. Sequential entrainment mapping of the atrial target chamber resulted in sequential acquisition of $3 \mathrm{D}$ anatomic locations together with their entrainment information. Inherent with the CARTO technology, those points were the basis for the virtual 3D chamber reconstruction on which the entrainment information was displayed in a color-coded fashion.

\section{NavX-based mapping procedures}

In $14(54 \%)$ patients, NavX was used as the electroanatomic mapping system for nonfluoroscopic 3D catheter orientation, color-coded 3D visualization of the entrainment information, and tagging of ablation sites. As described in detail previously, ${ }^{10} 3 \mathrm{D}$ anatomic orientation with NavX was obtained through integration of 3D computed tomographic (CT) images alone without atrial chamber reconstructions. In brief, for LA procedures, the PVs served as the main structures for registering the preacquired 3D CT image into the real-time mapping system. Further catheter manipulation and electrophysiologic measurements were performed within the registered 3D CT anatomy. Entrainment information from different anatomic locations was displayed on the CT anatomy in a color-coded fashion.

\section{Catheter ablation}

After delineation of the 3D location of the macroreentrant pathway, strategic linear lesion concepts were deployed in 


\section{Concept of Colour-coded PPI mapping}

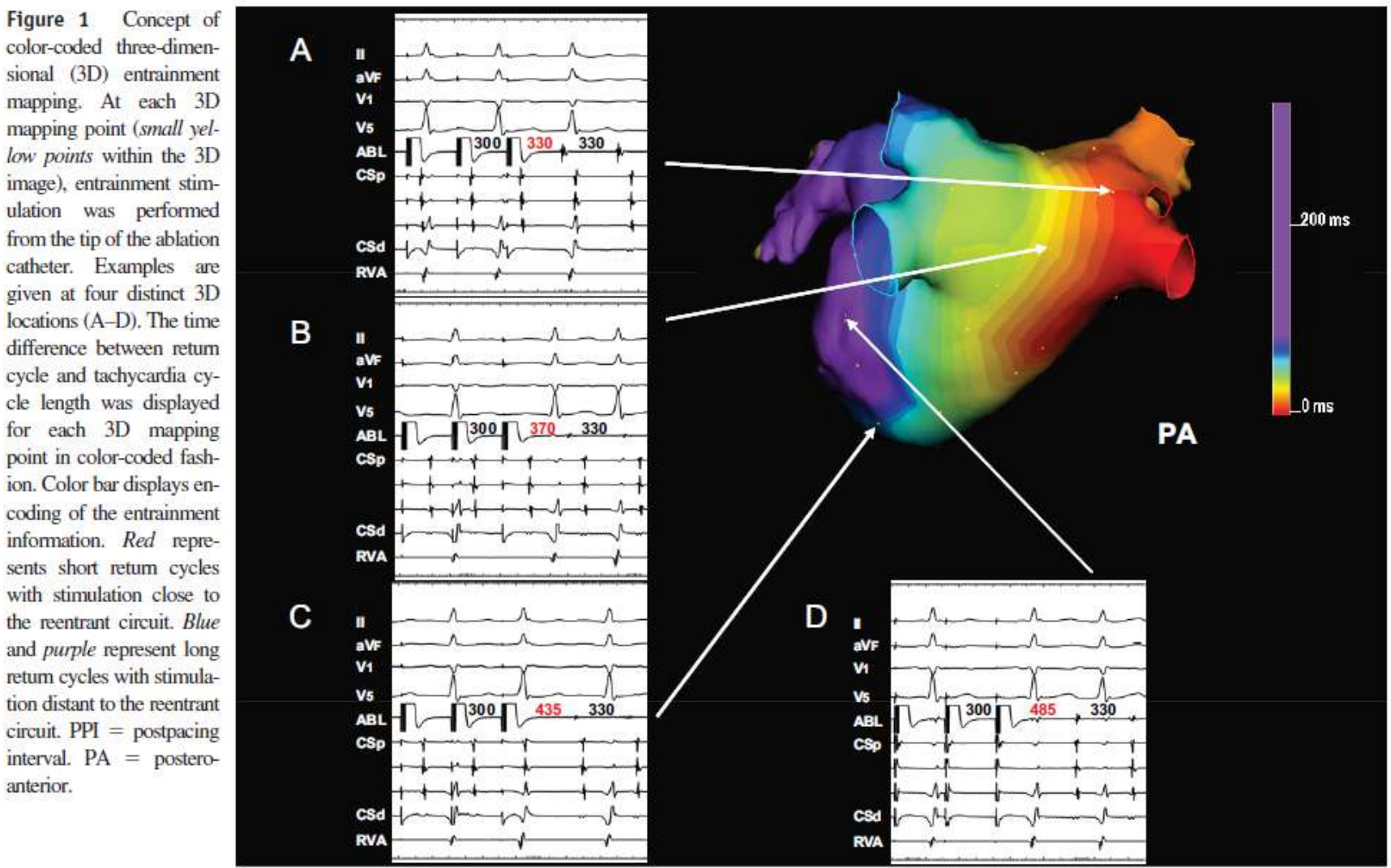

order to terminate the tachycardia. Table 2 summarizes the selected lesion line concepts chosen to target different types of macroreentrant circuits. Contrary to previous macroreentrant tachycardia mapping approaches, with our ablation concept it was not necessary to find and ablate the area of slow conduction and the critical isthmus of the respective tachycardia.

Radiofrequency alternating current was delivered in a unipolar mode between the irrigated-tip electrode of the ablation catheter (F-type irrigated-tip, NaviStar ThermoCool, Biosense Webster; M-Curve IBI Therapy Cooled Path, St. Jude Medical) and an external backplate electrode. Ablation in contact areas between the LA and the esophagus was avoided. The standard ablation setting consisted of a preselected catheter tip temperature of $50^{\circ} \mathrm{C}$, power $40 \mathrm{~W}$, and flow rate $30 \mathrm{~mL} / \mathrm{min}$. At the posterior LA near the esophagus, power delivery was reduced to $25 \mathrm{~W}$ and $20 \mathrm{~mL} / \mathrm{min}$.

Following ablation of the initial tachycardia, inducibility of further macroreentrant tachycardias was tested with 20 seconds of rapid burst stimulation during the atrial refractory period. Additionally occurring macroreentrant tachycardias were targeted according to the described protocol. Noninducibility for any macroreentrant tachycardia was the procedural end-point.

In patients with an LA origin of the macroreentrant circuit $(n=20)$, PV isolation was assessed and completed as documented by a multipolar mapping catheter. ${ }^{1}$ Differ- ential pacing for assessment of linear lesion continuity was not performed, except for right atrial cavotricuspid isthmus (CTI) ablations.

\section{Postprocedural care and follow-up}

Following patient selection and prior to ablation, a continuous 7-day-Holter ECG (Lifecard CF, Delmar Reynolds Medical Inc, Irvine, CA, USA) recording was obtained for all patients. The continuous 7-day-Holter ECG was repeated immediately after ablation and after 3, 6, and 12 months. In case of symptoms outside the recording period, patients were advised to contact our institution or the referring physician to provide ECG documentation. Documented macroreentrant tachycardia and/or AF longer than $30 \mathrm{sec}-$ onds was considered an episode of sustained macroreentrant tachycardia and/or AF recurrence.

As part of the study protocol, after ablation the antiarrhythmic medication was discontinued and patients received a beta-blocker, if tolerated. In case of macroreentrant tachycardia recurrences, reablation was scheduled 3 months after the index procedure.

Starting the day after the ablation procedure, patients received an oral anticoagulation with an international normalized ratio of 2.0 to 3.0. Anticoagulation was discontinued after the 6-month follow-up visit according to the CHADS2 score. 
Table 2 Selected lesion line concepts

\begin{tabular}{|c|c|}
\hline Macroreentrant tachycardia circuit & Ablation line concept \\
\hline Around pulmonary vein ostium & $\begin{array}{l}\text { Wide circumferential PV } \\
\text { isolation }\end{array}$ \\
\hline Perimitral & Mitral isthmus line \\
\hline Through LA roof & LA roof line \\
\hline Around $L A A^{*}$ & $\begin{array}{l}\text { Circumferential LAA } \\
\text { ablation }\end{array}$ \\
\hline Around oval fossa (septal) $\dagger$ & $\begin{array}{l}\text { 1. Left atrial septal line } \\
\text { (MA to right PVs) } \\
\text { 2. Right atrial septal } \\
\text { line (SVC to IVC) }\end{array}$ \\
\hline Right atrial isthmus dependent & Right atrial isthmus line \\
\hline Right atrial scar related & $\begin{array}{l}\text { Connection between } \\
\text { scar and IVC }\end{array}$ \\
\hline Right atrial upper loop & $\begin{array}{l}\text { Connection between } \\
\text { superior TA and SVC }\end{array}$ \\
\hline Within the CS & Line within the CS \\
\hline
\end{tabular}

$C S=$ coronary sinus; IVC = inferior vena cava; $L A=$ left atrium; LAA = left atrial appendage; SVC $=$ superior vena cava; $T A=$ tricuspid annulus.

*Procedural end-point was tachycardia termination and noninducibility of the patient. Complete electrical isolation of the LAA was not enforced. †Septal macroreentrant tachycardias were primarily treated with a left atrial septal ablation line between the mitral annulus (MA) and right-sided pulmonary veins (PVs). In cases in which the tachycardia failed to terminate, an additional ablation line was placed at the right atrial side of the interatrial septum connecting superior and inferior caval vein.

\section{Statistical analysis}

Data were tested for normal (gaussian) distribution using the Kolmogorov-Smirnov test. Normally distributed continuous variables are presented as mean \pm SD. In case of a nongaussian distribution, median and quartiles are given. Categorical variables are expressed as number and percentage of patients.

Differences of continuous normally distributed data were tested for statistical significance using the t-test for independent samples. In case of continuous data with a nongaussian distribution, the Mann-Whitney U-test was used. Differences of categorical data were tested for statistical significance using Chi-square test. All analyses were performed using SPSS for Windows (Release 12.0, SPSS, Inc., Chicago, IL, USA). $P<.05$ was considered significant.

\section{Results \\ Characteristics of detected macroreentrant circuits}

Fifteen $(58 \%)$ patients presented with a single macroreentrant tachycardia. In $11(42 \%)$ patients, further macroreentrant tachycardias occurred spontaneously or were inducible after ablation of the initial reentrant circuit. In total, 39 macroreentrant tachycardias were ablated in 26 patients. Table 1 summarizes the arrhythmia characteristics of these macroreentrant tachycardias.

Of the 39 reentrant circuits, $23(59 \%)$ were located within the LA, 9 (23\%) within the RA, $5(13 \%)$ within the intraatrial septum, and $2(5 \%)$ within the CS (Figures 2 through 6).
The macroreentrant tachycardia mechanisms detected were perimitral (9), around the PV ostium (6), through the LA roof (5), around the left atrial appendage (LAA; 3), RA isthmus dependent (6), RA scar related (2), around the superior vena cava (1), within the septum (5), and within the CS (2) (Table 1).

\section{Macroreentrant tachycardia following previous AF ablation}

Nineteen $(73 \%)$ patients presented with macroreentrant tachycardia following previous $\mathrm{AF}$ ablation procedures (catheter interventional circumferential PV ablation with radiofrequency energy 15, intraoperative circumferential PV ablation with cryoenergy 4 ). Ten (53\%) patients (only catheter interventional circumferential PV ablation) had received additional linear LA lesion lines in the mitral isthmus, at the LA roof, and at the interatrial septum during the initial AF ablation procedure. Table 1 correlates the prior ablation concept with the current macroreentrant tachycardias to distinguish gap-related macroreentrant tachycardias from newly occurring arrhythmias.

The 19 patients with macroreentrant tachycardias following $\mathrm{AF}$ ablation presented with 27 macroreentrant tachycardias. Of these macroreentrant tachycardias, $15(56 \%)$ were gap related and $12(44 \%)$ were not gap related. The arrhythmia mechanisms found in these patients were around PV ostium (6), perimitral (6), through LA roof (3), within septum (3), CTI dependent (4), around LAA (2), within CS (2), and around RA scar (1). A gap-related pathophysiology of the macroreentrant tachycardia was found in $6(100 \%)$ of 6 macroreentrant tachycardias around PV ostium, $3(50 \%)$ of 6 perimitral macroreentrant tachycardias, $2(67 \%)$ of 3 macroreentrant tachycardias through LA roof, 1 (33\%) of 3 septal macroreentrant tachycardias, and $2(50 \%)$ of 4 CTIdependent macroreentrant tachycardias.

\section{Macroreentrant tachycardia without previous AF ablation}

Seven $(27 \%)$ patients presented with macroreentrant tachycardias without previous AF ablation procedures. Five manifested the tachycardia as a spontaneously occurring type of atypical atrial flutter, and two had atrial macroreentrant tachycardia following surgical closure of an atrial septal defect.

In those patients, 12 macroreentrant tachycardias were mapped and ablated: perimitral macroreentrant tachycardia (3), through LA roof (2), septal macroreentrant tachycardia (2), around LAA (1), CTI dependent (2), around RA scar (1), and around superior vena cava (1).

\section{Procedural data}

Procedural duration, fluoroscopy time, and radiofrequency time measured $181 \pm 58(100-350)$ minutes, $37 \pm 19$ (15-81) minutes, and $31 \pm 17(8-84)$ minutes, respectively. Overall, $35 \pm 17$ (14-77) entrainment points (PPI points) were acquired during the procedure. PPI mapping time measured $74 \pm 46(12-200)$ minutes per studied re- 


\section{Example of a perimitral MRT}

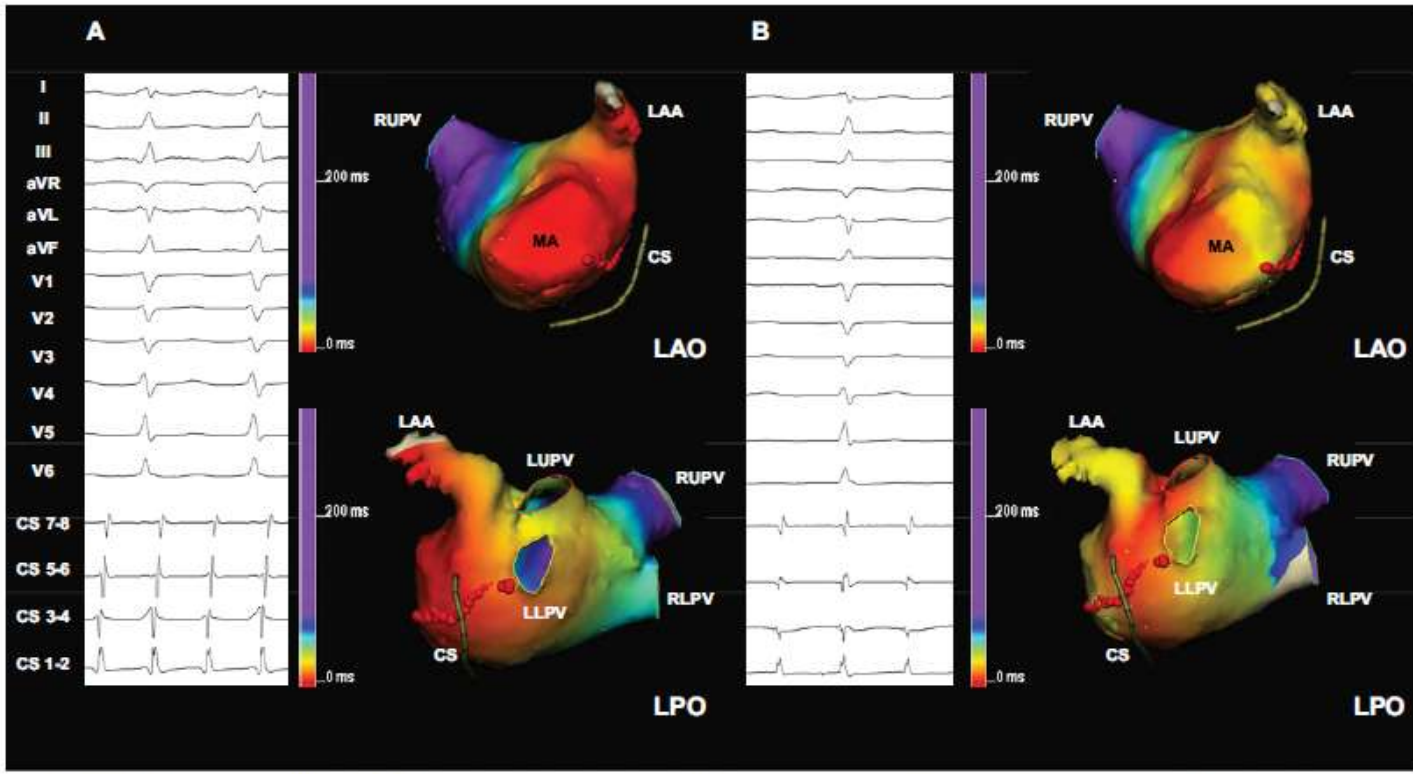

Figure 2 A: Patient 16. Postpacing interval (PPI) mapping performed with NavX in a preregistered three-dimensional (3D) computed tomographic image of the left atrium. Map reveals a reentrant circuit around the mitral valve. A mitral isthmus line was placed as the strategic lesion line. B: During ablation, the tachycardia cycle length increased. Coronary sinus (CS) sequence remained constant, with CS 1-2 being earliest. Remapping was performed around the initial reentrant circuit. The 3D PPI map now displays a variant of a perimitral circuit that does not cross between the left atrial appendage (LAA) and the superior mitral annulus (MA) but instead takes the ridge between the LAA and left upper pulmonary vein (LUPV). Endocardial completion of the mitral isthmus line eventually terminated the tachycardia. For statistical analysis, both tachycardias were treated as a single perimitral circuit. LAO $=$ left anterior oblique; $L P O=$ left posterior oblique; LLPV = left lower pulmonary vein; RLPV = right lower pulmonary vein; RUPV = right upper pulmonary vein.

entrant circuit. Periprocedural complications were not observed.

Comparison of procedural data in patients who presented with different macroreentrant tachycardias showed signifi- cantly more PPI points (41 [27;64] vs $25[21 ; 32] ; P=.003)$ and a trend toward longer fluoroscopy time $(47[24 ; 58]$ vs $30[20 ; 38] ; P=.087)$ in patients with more than one reentrant circuit. Comparing LA macroreentrant tachycardia

Example of a MRT around the ostium of the left sided PVs

Figure 3 Patient 26 Postpacing interval mapping performed with NavX in a preregistered three-dimensional (3D) computed tomographic image of the left atrium. Map reveals a reentrant circuit around the common ostium of the leftsided pulmonary veins. A circumferential ablation line around the leftsided PVs was placed as a strategic lesion line. $\mathrm{LL}=$ left lateral; $\mathrm{PA}=$ posteroanterior; Sup = superior. Other abbreviations as in Figure 2.

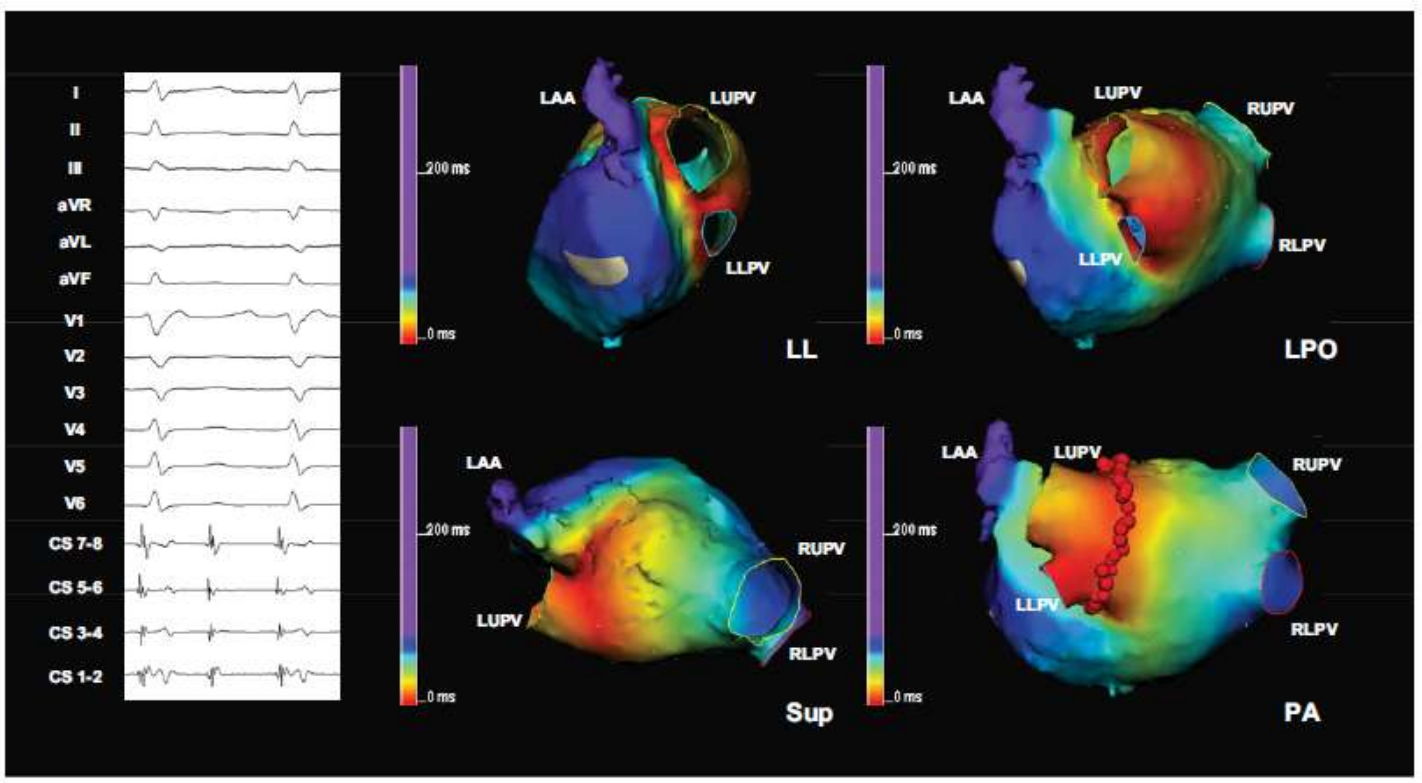




\section{Example of a MRT around the LAA}

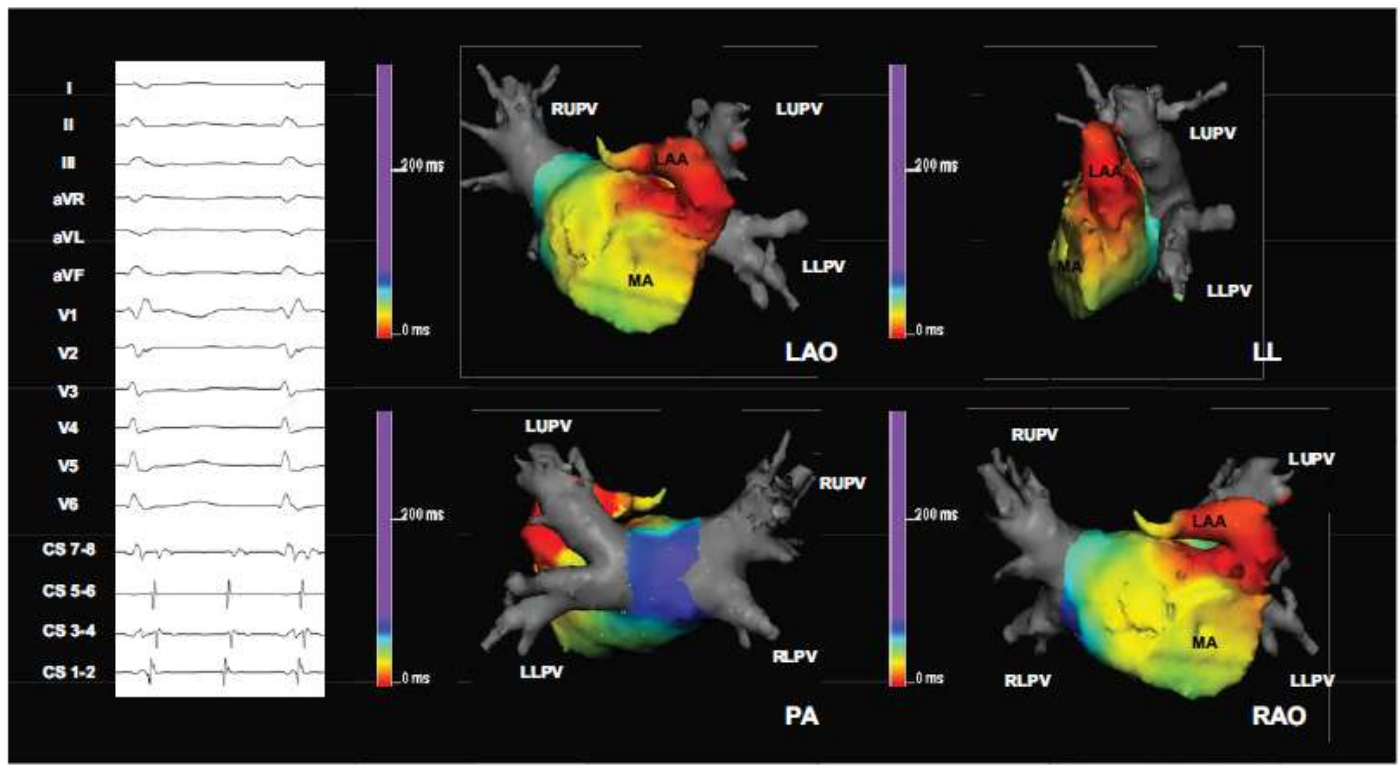

Figure 4 Patient 23. Postpacing interval mapping performed with NavX in a preregistered three-dimensional (3D) computed tomographic image of the left atrium. The PVs were isolated after previous circumferential PV ablation. Respective mapping points with failure to capture the left atrium were encoded as scar areas (gray). Map reveals a reentrant circuit around the left atrial appendage (LAA). Circumferential ablation around the LAA terminated the tachycardia. LAA isolation was not enforced. RAO = right anterior oblique. Other abbreviations as in previous figures.

and RA macroreentrant tachycardia patients showed a significantly longer radiofrequency lesion time (36 [25;49] vs $17[9 ; 28] ; P=.03)$ and a trend toward longer procedural duration $(210[103 ; 275]$ vs $170[140 ; 190] ; P=.783)$ in patients with LA macroreentrant tachycardia. Patients with septal macroreentrant tachycardias required significantly

\section{Example of a CTI dependent MRT}

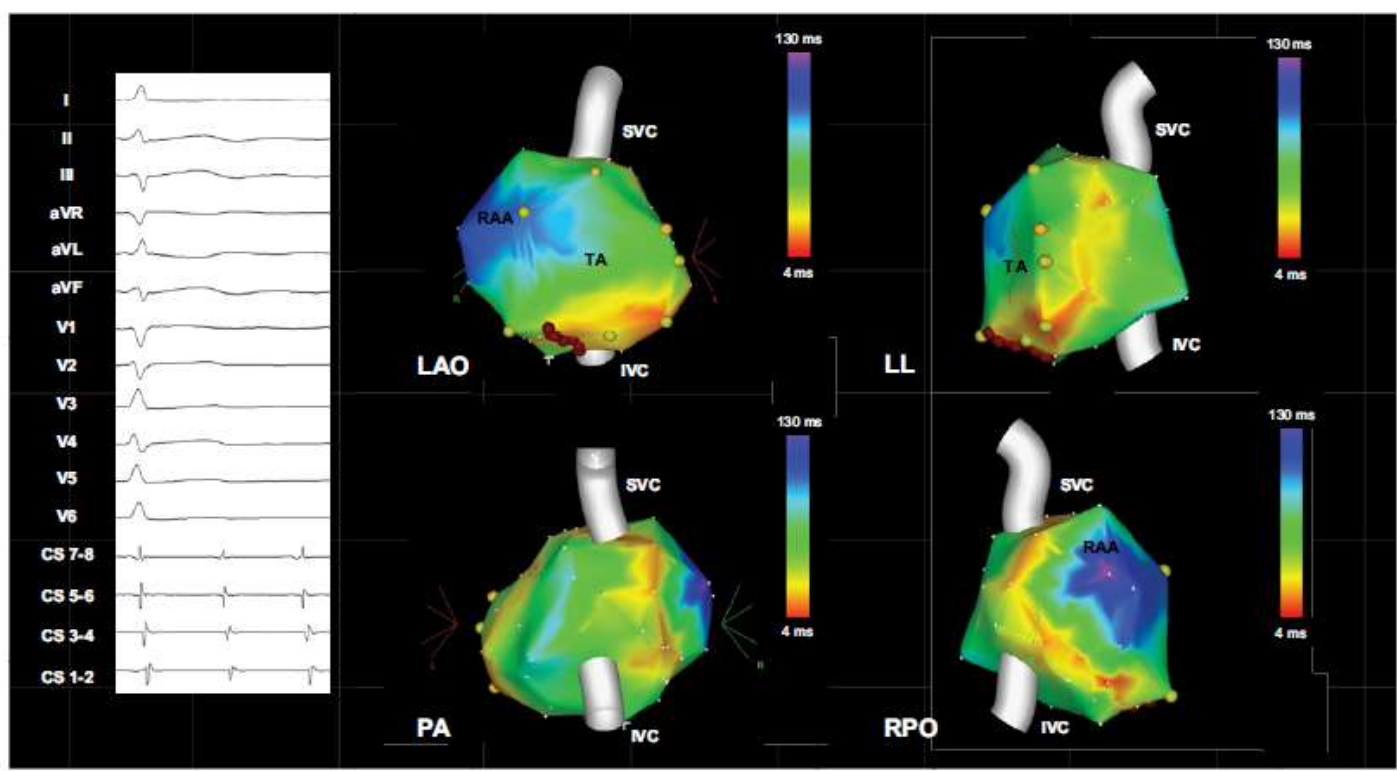

Figure 5 Patient 4. Postpacing interval (PPI) mapping performed with CARTO. The three-dimensional anatomy was reconstructed together with the PPI mapping. Map reveals cavotricuspid isthmus (CTI)-dependent reentrant circuit. However, contrary to a typical peritricuspid atrial flutter, the circuit takes its course along the annular portion of the interatrial septum, crosses to the posterior right atrium (RA) in front of the superior vena cava (SVC), comes along the posterior RA through the terminal crest, and returns back to the CTI at the bottom of the RA. Ablation of the CTI terminated the tachycardia. IVC = inferior vena cava; RAA = right atrial appendage; $\mathrm{RPO}=$ right posterior oblique; TA $=$ tricuspid annulus. Other abbreviations as in previous figures. 


\section{Example of a MRT within the interatrial septum}

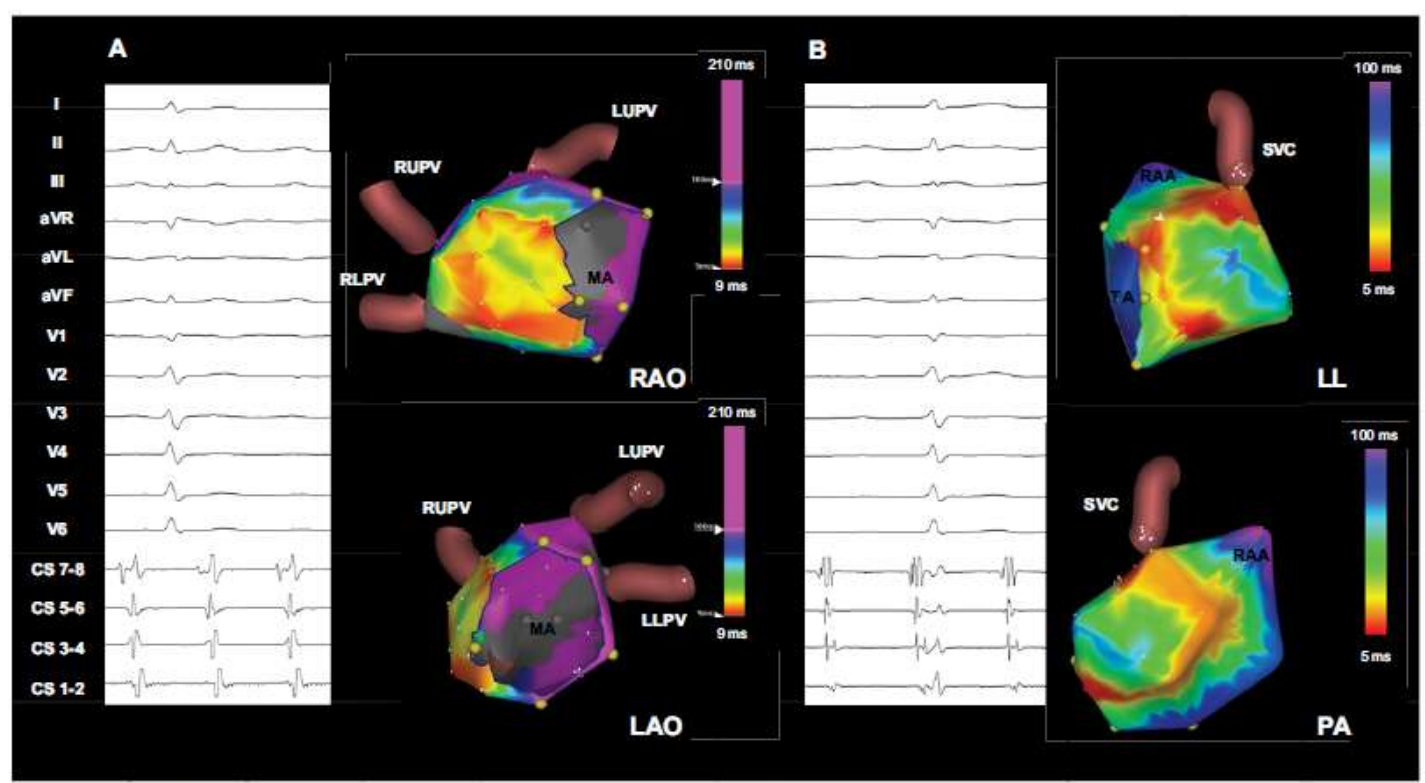

Figure 6 A: Patient 18. Postpacing interval (PPI) mapping performed with CARTO. The three-dimensional anatomy was reconstructed together with the PPI mapping. Scar areas after previous left atrial AF ablation (circumferential PV ablation + linear lesions) with respective inability to capture the left atrium were encoded in gray. Map reveals a septal reentrant circuit. A left atrial septal ablation line was placed as a strategic lesion line. B: During ablation, the tachycardia cycle length increased. CS sequence remained constant, with CS 7-8 being earliest; however, the morphology of the CS atrial electrogram changed significantly. Remapping of the septum from the right atrial side was performed. The three-dimensional PPI map now displays a variant of a septal circuit that takes the annular portion of the interatrial septum, goes along the inferior aspects of the septum toward the posterior right atrium, crosses the terminal crest, and comes back to the annulus along the septal aspects of the superior vena cava (SVC) ostium and the superior portion of the interatrial septum. An ablation line from the SVC to the inferior vena cava over the septum terminated the tachycardia. For statistical analysis, both tachycardias were treated as a single septal circuit. Abbreviations as in previous figures.

longer fluoroscopy time (53 [47;75] vs $29[20 ; 40]$;) $P=$ $.009)$ and showed a trend toward more PPI points (42 [34;55] vs 27 [22;37]; $P=.081)$.

\section{Rhythm outcome and follow-up}

All 39 macroreentrant tachycardias were successfully ablated. In addition, for all 20 patients with LA macroreentrant tachycardias, PV isolation was completed and verified by a multipolar mapping catheter. At the end of the procedure, all $26(100 \%)$ patients remained noninducible for any macroreentrant tachycardia.

Two $(40 \%)$ of five septal macroreentrant tachycardias that did not terminate with the LA septal ablation line required further ablation from the right side of the interatrial septum. Three $(33 \%)$ of 9 perimitral macroreentrant tachycardias required an epicardial completion of the mitral isthmus line from within the CS in order to terminate the tachycardia.

The follow-up period covered $302 \pm 82$ days (range 166-473 days). Follow-up was performed with serial 7-day-Holter ECG. In total, 16,460 hours of continuous Holter ECG recording were analyzed for the 26 patients. During follow-up, all 26 patients remained free from antiarrhythmic medication.

Three $(12 \%)$ patients showed recurrences of macroreentrant tachycardia that were successfully ablated during a second procedure. One patient (no. 3) with a perimitral macroreentrant tachycardia showed recurrence of the perimitral macroreentrant tachycardia; one patient (no. 7) with LAA macroreentrant tachycardia showed a recurrence of the LAA macroreentrant tachycardia; and one patient (no. 5) with a CS macroreentrant tachycardia developed a new macroreentrant tachycardia around the left lower PV. None of the 26 patients experienced recurrences of AF.

\section{Discussion}

\section{Main findings of the study}

The results of this study show that in patients with atrial macroreentrant tachycardia, color-coded 3D entrainment mapping is feasible to accurately determine and visualize the 3D location of the entire reentrant circuit. Especially in patients with multiple atrial scars, multiple discontinuous ablation lines, and subsequently multiple areas of slow conduction, this approach helps to determine the true nature of the reentrant circuit. It represents a shift in the approach of mapping and ablating atrial macroreentrant tachycardias such that the area of slow conduction of the reentrant circuit was not targeted, but the reentrant circuit was dissected at an anatomically convenient location through a strategic linear ablation line.

Using this approach, all inducible macroreentrant tachycardias were successfully mapped and ablated, and long- 
term efficacy was high with a recurrence rate of $8 \%$. Thus, our approach is (1) clinically straightforward, (2) easy to understand and to apply, and (3) highly successful.

\section{Role of color-coded 3D entrainment mapping}

Atrial macroreentrant tachycardias are typical secondary arrhythmias occurring after AF ablation procedures and are being seen increasingly in the interventional electrophysiology field. Successful catheter interventional mapping and ablation of this arrhythmia has been reported. ${ }^{11}$ Sequential activation mapping commonly supported by $3 \mathrm{D}$ mapping systems is the standard of therapy. It requires highly experienced electrophysiologists together with long fluoroscopy and procedural times. ${ }^{11}$

With activation mapping, however, determination of the arrhythmia can be difficult due to the complex $3 \mathrm{D}$ anatomies of the pretreated area and the partially extensive and discontinuous previous ablation damage. Because of these limitations, not uncommonly the tachycardia cannot be terminated, and the patient suffers from recurrences. ${ }^{1}$

Color-coded 3D entrainment mapping, on the other hand, allows determination of the location of the reentrant circuit and the obstacle around which the tachycardia is circulating, even though the area of slow conduction of the tachycardia is not described. Subsequently, strategic lesion lines, mainly connecting to anatomic barriers, can be applied to dissect the circuit and treat the arrhythmia (Table 2).

Despite today's predominance of atrial macroreentrant tachycardias following previous AF ablation procedures, these arrhythmias also can occur either spontaneously or after cardiac surgery in the form of incisional atrial flutter. ${ }^{4,8}$ Those patients were included in the present study in order to analyze the feasibility of the 3D PPI mapping approach for the entire clinical range of patients presenting with atrial macroreentrant tachycardia.

\section{Color-coded 3D entrainment mapping in the present study}

Using that approach in our study, we could successfully terminate all 39 inducible macroreentrant tachycardias, and all patients remained noninducible upon aggressive burst stimulation. The approach advanced our understanding of the pathophysiology of the reentrant circuit and the spread of electrical activation over the atria. We found CTI-dependent atrial flutter, which did not use a typical peritricuspid course but traversed from the RA roof to the posterior RA wall, through the terminal crest and back to the CTI at the bottom of the RA (Figure 5). Whether conventional activation mapping would have been able to describe the circuit that precisely is questionable. Similarly, we were able to distinguish perimitral atrial flutter that crossed between the LAA and superior mitral annulus and perimitral atrial flutter that used the ridge between the LAA and left superior PV instead (Figure 2). In addition, we found tachycardias coming from the PVs, for which the complex antrum anatomy would have impeded identification of the critical isthmus by activation mapping and therefore could have been misclas- sified as focal arrhythmias. Three-dimensional PPI mapping around the PV ostium clearly proved the presence of a reentrant circuit (Figure 3). The same applies for reentrant tachycardias originating from within the CS, with related difficulties in catheter access.

Concordant with previous publications on atrial macroreentrant tachycardia, we found several patients with more than one possible reentrant circuit. ${ }^{1}$ In our series, $42 \%$ of the patients had multiple circuits. After termination of the initial tachycardia, in these patients further macroreentrant tachycardias either occurred spontaneously or were inducible upon rapid burst stimulation during the atrial refractory period. Two patients showed the maximum of three reentrant circuits. Because of this phenomenon, close awareness is needed to recognize even minor changes in TCL or CS activation sequence during ablation, which may indicate a change in the reentrant circuit and necessitate further entrainment mapping.

\section{Clinical efficacy}

During almost 1-year follow-up with repetitive 7-dayHolter ECGs, the long-term success was high, with recurrences of pretreated macroreentrant tachycardias in only 2 (8\%) patients (perimitral 1, around LAA 1). An additional patient developed a new macroreentrant tachycardia that previously was not inducible and therefore was untreated.

These results are interesting with respect to the procedural end-point. From an electrophysiologic point of view, only the wide circumferential ablation line for treatment of macroreentrant tachycardias around the PV ostium and the RA isthmus line for treatment of CTI-dependent macroreentrant tachycardias were validated with bidirectional conduction block. All other lines were not validated with differential pacing because the procedural end-point was tachycardia termination and noninducibility of any macroreentrant tachycardia.

One condition that likely had a positive influence on long-term efficacy is that isolation of the PVs was assessed and completed in all 20 patients with at least one LA macroreentrant tachycardia after termination of the macroreentrant tachycardias. Previous studies have described the role of complete PV isolation in patients treated for LA macroreentrant tachycardia. ${ }^{1,12,13}$

\section{Characteristics of different types of macroreentrant tachycardias}

Comparison of procedural data between patients with different macroreentrant tachycardias revealed a significantly longer radiofrequency lesion time and a trend toward longer procedural duration in patients with LA macroreentrant tachycardia. A likely explanation for this observation is the assessment and completion of PV isolation additionally performed after tachycardia termination in patients with LA macroreentrant tachycardia.

Patients with septal macroreentrant tachycardias had significantly longer fluoroscopy time and a trend toward more PPI mapping points. Ablation of septal macroreentrant 
tachycardia is performed in the anatomic vicinity toward the compact AV node. Therefore, protection of the AV node is mandatory, as described previously. ${ }^{1,14}$ To prevent damage to the AV node, in addition to the positional information provided by the $3 \mathrm{D}$ mapping system we regularly confirmed the position of the ablation electrode on fluoroscopy. Taking into account the location of the AV node, we applied either a very low septal ablation line from the left paraseptal mitral annulus or a very high septal ablation line from the superior mitral annulus. Two of five septal macroreentrant tachycardias did not terminate with a LA septal ablation line. In those patients, an additional RA septal ablation line terminated the tachycardia. In addition, in order to protect the compact AV node, this line was placed by connecting the superior with the inferior caval vein along the route typically taken for transseptal puncture. None of our patients showed temporary or permanent alterations of AV nodal conduction.

Patients with macroreentrant tachycardias circulating around the LAA ostium underwent a circumferential ablation around the LAA until the tachycardia terminated and the patient remained noninducible. Complete bidirectional isolation of the LAA was not enforced and may be seen as a reason for tachycardia recurrence in one of the three patients with LAA macroreentrant tachycardia. However, our approach was based on considerations of atrial transport function and risk of thrombogenesis in an electrically silent and noncontracting LAA. Given these considerations, we opted for a higher risk of macroreentrant tachycardia recurrence rather than a higher thromboembolic risk.

Comparison of procedural data between patients with gap-related and newly occurring macroreentrant tachycardias did not show any difference. Gap-related mechanisms were common in patients with macroreentrant tachycardia following previous $\mathrm{AF}$ ablation. Out of these, $68 \%$ had at least one gap-related macroreentrant tachycardia. On the other hand, these patients also showed additional macroreentrant tachycardias not related to previous ablation lines. In total, $56 \%$ of all macroreentrant tachycardias in patients with previous AF ablation were shown to be gap related, a value number that is smaller compared with previous publications. ${ }^{1}$ However, the lack of a precise description of the initial AF ablation concept for the individual patient makes difficult the comparison of these data with ours. It is possible that greater usage of linear ablation lines in addition to circumferential PV ablation during the initial AF ablation procedure resulted in a greater number of gap-related macroreentrant tachycardias in that cohort.

\section{Study limitations}

Color-coded 3D PPI mapping requires stable macroreentrant tachycardias at an entrainable CL. Therefore, the method cannot be used for arrhythmia description in patients with continuously changing tachycardia pathways, unstable arrhythmias, or repetitive degeneration into AF.

Entrainment stimulation performed from within an area of slow conduction carries the risk of paradoxically long
PPIs, tachycardia termination, and tachycardia degeneration. In practice, that situation was rare. In three patients, a tachycardia was terminated during entrainment. In two patients, the macroreentrant tachycardia changed. In all of these cases, the catheter was positioned where the local bipolar electrogram was of low amplitude, broad, fragmented, and mid-diastolic, indicating a stimulation site within the area of slow conduction. The map could be completed when in these positions entrainment was repeated using reduced stimulation output just above the local pacing threshold.

The present study is monocentric. A comparison of our approach with the established method of activation mapping with respect to procedural and efficacy data clearly requires a larger comparative study.

\section{Conclusion}

Color-coded 3D entrainment mapping is a new method for direct visualization of the entire reentrant circuit and the selection of a strategic ablation line not necessarily targeting the area of slow conduction of the arrhythmia. The approach is feasible, provides detailed information on the location of the reentrant circuit, and results in an excellent rate of tachycardia termination with satisfying long-term clinical efficacy.

\section{References}

1. Chae S, Oral H, Good E, et al. Atrial tachycardia after circumferential pulmonary vein ablation of atrial fibrillation: mechanistic insights, results of catheter ablation, and risk factors for recurrence. J Am Coll Cardiol 2007;50:1788-1790.

2. Stevenson WG, Khan $H$, Sager $P$, et al. Identification of reentry circuit sites during catheter mapping and radiofrequency ablation of ventricular tachycardia late after myocardial infarction. Circulation 1993;88:1647-1670.

3. Waldo AL. Atrial flutter: entrainment characteristics. J Cardiovasc Electrophysiol 1997;8:337-352.

4. Delacretaz E, Ganz LI, Soejima K, et al. Multi atrial macro-re-entry circuits in adults with repaired congenital heart disease: entrainment mapping combined with three-dimensional electroanatomic mapping. J Am Coll Cardiol 2001;37: $1665-1676$.

5. Miyazaki H, Stevenson WG, Stephenson K, et al. Entrainment mapping for rapid distinction of left and right atrial tachycardias. Heart Rhythm 2006:3:516-523.

6. Shalganov TN, Vatasescu R. Paprika D, et al. A simple algorithm for defining the mechanism and the chamber of origin in atrial tachycardias. J Electrocardiol 2006;39:369-376.

7. Piorkowski C, Kottkamp H, Gerds-Li JH, et al. Steerable sheath catheter navigation for ablation of atrial fibrillation: a case-control study. Pacing Clin Electrophysiol 2008;31:863-873.

8. Morton JB, Sanders P, Deen V, et al. Sensitivity and specificity of concealed entrainment for the identification of a critical isthmus in the atrium: relationship to rate, anatomic location and antidromic penetration. J Am Coll Cardiol 2002; 39:896-906.

9. Chan DP, Van Hare GF, Mackall JA, et al. Importance of atrial flutter isthmus in postoperative intra-atrial reentrant tachycardia. Circulation 2000;102:1283-1289.

10. Piorkowski C, Kircher S, Arya A, et al. Computed tomography model-based treatment of atrial fibrillation and atrial macro-re-entrant tachycardia. Europace 2008; 10:939-948.

11. Jais $\mathrm{P}$, Shah DC, Haissaguerre $\mathrm{M}$, et al. Mapping and ablation of left atrial flutters. Circulation 2000;101:2928-2934.

12. Ouyang F, Antz M, Ernst S, et al. Recovered pulmonary vein conduction as a dominant factor for recurrent atrial tachyarrhythmias after complete circular isolation of the pulmonary veins: lessons from double lasso technique. Circulation 2005;111:127-135.

13. Cummings JE, Schweikert R, Saliba W, et al. Left atrial flutter following pulmonary vein antrum isolation with radiofrequency energy: linear lesions or repeat isolation. J Cardiovasc Electrophysiol 2005;16:293-297.

14. Marrouche NF, Natale A, Wazni OM, et al. Left septal atrial flutter: electrophysiology, anatomy, and results of ablation. Circulation 2004;109:2440-2447. 


\subsection{Entwicklungen zu Katheterstabilität und objektivierbarem Wandkontakt}

4.2.1. Katheternavigation mittels steuerbarer Zugangsschleuse bei Vorhofflimmerablation: Eine Case-Control Studie

Zitierweise:

Christopher Piorkowski, M.D., Hans Kottkamp, M.D., Jin-Hong Gerds-Li, M.D., Arash Arya, M.D., Philipp Sommer, M.D., Nicos Dagres, M.D., Masahiro Esato, M.D., Sam Riahi, M.D., Sebastian Weiss, M.D., Simon Kircher, M.D., and Gerhard Hindricks, M.D.*

Steerable Sheath Catheter Navigation for Ablation of Atrial Fibrillation: A CaseControl Study.

PACE 2008; 31:863-873. 


\title{
Steerable Sheath Catheter Navigation for Ablation of Atrial Fibrillation: A Case-Control Study
}

\author{
CHRISTOPHER PIORKOWSKI, M.D., * HANS KOTTKAMP, M.D.,† \\ JIN-HONG GERDS-LI, M.D., * ARASH ARYA, M.D., * PHILIPP SOMMER, M.D., * \\ NICOS DAGRES, M.D., * MASAHIRO ESATO, M.D., * SAM RIAHI, M.D., * \\ SEBASTIAN WEISS, M.D., * SIMON KIRCHER, M.D., * and GERHARD HINDRICKS, M.D. * \\ From the *University of Leipzig, Heart Center, Leipzig, Germany; and +Clinic Hirslanden, Heart Center, Zurich, \\ Switzerland
}

Background: Lack of stable access to all desired ablation target sites is one of the limitations for efficacious circumferential left atrial (LA) pulmonary vein (PV) ablation. Targeting that, new catheter navigation technologies have been developed. The aim of this study was to describe atrial fibrillation (AF) mapping and ablation using manually controlled steerable sheath catheter navigation and to compare it against an ablation approach with a nonsteerable sheath.

Methods and Results: In this case-control-analysis 245 consecutive patients (controls) treated with circumferential left atrial PV ablation were matched with 105 subsequently consecutive patients (cases) ablated with a similar line concept but mapping and ablation performed with a manually controlled steerable sheath. One hundred sixty-six patients were selected to be included into 83 matched patient pairs. Ablation success was measured with serial 7-day Holter electrocardiograms. Patients ablated with the steerable sheath showed an increase in the success rate (freedom from AF) from $56 \%$ to $77 \%(P=0.009$ ) after a single procedure and 6 months of follow-up. With respect to procedural data no difference could be found for procedure time, fluoroscopy time, irradiation dose, and radiofrequency (RF) burning time. With the steerable sheath mean procedural $R F$ power (33 \pm 9 vs $41 \pm 4 W ; P<0.0005$ ) and total $R F$ energy delivery $(97,498$ vs $111,864 \mathrm{~J} ; P<0.005)$ were significantly lower and the rate of complete $P V$ isolation significantly increased from $10 \%$ to $52 \%(P<0.0005)$. The complication rate was the same in both groups . Among different arrhythmia, procedure, and patient characteristics, the lack of early postinterventional arrhythmia recurrences was the only but powerful predictor for long-term ablation success.

Conclusions: An AF mapping and ablation approach solely using a manually controlled steerable sheath for catheter navigation improved the outcome of circumferential left atrial PV ablation at similar intervention times and similar complication rates. The 6-month success rate after a single LA intervention increased from $56 \%$ to $77 \%$. (PACE 2008; 31:863-873)

ablation, atrial fibrillation, electrophysiology, clinical, new technology

\section{Introduction}

Catheter interventional ablation of atrial fibrillation (AF) is increasingly used as a potentially curative treatment in patients suffering from arrhythmia. Acknowledging the two pathophysiological cornerstones of initiating triggers and perpetuating substrate, different ablation concepts have been developed. ${ }^{1-3}$ Placement of circumferential left atrial (LA) ablation lines around the funnels of the pulmonary veins (PV) is a concept commonly used today. ${ }^{2}$ It requires stable, reproducible, and reliable access to all ablation target sites along the desired circumferential lesion lines. Therefore, currently the complex three dimensional LA anatomy

Address for reprints: Christopher Piorkowski, M.D., University of Leipzig, Heart Center, Department of Electrophysiology, Strümpellstrasse 39, 04289 Leipzig, Germany. Fax: +49-341865-1460; e-mail: cp7026@yahoo.de

Received September 6, 2007; revised December 16, 2007; accepted April 8, 2008. and the lack of catheter stability, and left atrial wall contact are practical limitations for that concept. Subsequently discontinuous and nontransmural ablation lines are thought to be the main reason for $\mathrm{AF}$ recurrences.

Manually and robotic controlled steerable sheath technologies have been developed to improve catheter navigation, catheter stability, and LA wall contact. Thus, this study analyzed the outcome after circumferential left atrial PV ablation using a new mapping and ablation approach based on manually controlled steerable sheath navigation. In a case-control analysis, the outcome was compared against a control group ablated with a conventional nonsteerable sheath.

\section{Methods}

Study Design and Patient Characteristics

In this case-control-analysis 245 consecutive patients (controls) treated with circumferential left atrial PV ablation between October 2004 and

C2008, The Authors. Journal compilation (C2008, Blackwell Publishing, Inc. 
December 2005 using a conventional nonsteerable transseptal sheath (Mullins; Cook Inc., Bloomington, IN, USA) were matched with 105 subsequently consecutive patients (cases) ablated between January 2006 and October 2006 with a similar line concept but mapping and ablation performed with a manually controlled steerable sheath (Agilis, St. Jude Medical, St. Paul, MN, USA). The matching criteria included patient's age, patient's gender, paroxysmal or persistent AF, duration of the AF history, previous AF ablations, and underlying cardiac disease. According to these criteria, 83 matched pairs could be selected.

The 166 patients ( 122 men, 44 women, mean age $55 \pm 9$ years) included in that case-controlanalysis showed the following patient and arrhythmia characteristics (Table I). One hundred thirtytwo $(80 \%)$ patients suffered from paroxysmal AF and $34(20 \%)$ patients suffered from persistent AF, respectively. Persistent AF was defined as continuous arrhythmia throughout the 7-day Holter electrocardiogram (ECG) prior to ablation. Organic heart disease was present in 26 (16\%) patients (coronary artery disease $\mathrm{n}=8$, valvular heart disease $\mathrm{n}=16$, dilated cardiomyopathy $\mathrm{n}=2$ ) and $68(41 \%)$ patients had a history of arterial hypertension. Eighty-eight (53\%) patients had so-called lone AF. Mean left ventricular ejection fraction measured $61 \pm 6 \%$, and mean left atrial diame-

\section{Table I.}

Patient and Arrhythmia Characteristics in the Group of Patients Treated with Steerable Sheath Catheter

Navigation (Cases) and in the Group of Patients Treated with a Nonsteerable Sheath (Controls).

\begin{tabular}{|c|c|c|}
\hline & $\begin{array}{l}\text { Cases } \\
(n=83)\end{array}$ & $\begin{array}{l}\text { Controls } \\
(n=83)\end{array}$ \\
\hline Age, [years] $]^{\dagger}$ & $55 \pm 9$ & $55 \pm 9$ \\
\hline Male, n (\%) & $61(73)$ & $61(73)$ \\
\hline Paroxysmal AF, n (\%) & $66(80)$ & $66(80)$ \\
\hline AF history, [months] $]^{\dagger \dagger}$ & \multicolumn{2}{|c|}{$52(28 ; 99) 54(32 ; 100)$} \\
\hline Arterial hypertension, n (\%) & $34(41)$ & $34(41)$ \\
\hline Coronary artery disease, $\mathrm{n}(\%)$ & $4(5)$ & $4(5)$ \\
\hline Dilated cardiomyopathy & $1(1)$ & $1(1)$ \\
\hline Valvular heart disease, $\mathrm{n}(\%)$ & $8(10)$ & $8(10)$ \\
\hline Lone AF, n (\%) & $44(53)$ & $44(53)$ \\
\hline 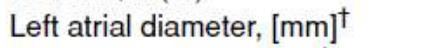 & $36 \pm 13$ & $38 \pm 8$ \\
\hline LV ejection fraction, $[\%]^{\dagger}$ & $60 \pm 7$ & $62 \pm 8$ \\
\hline Prior AF ablation, $\mathrm{n}(\%)$ & $10(12)$ & $10(12)$ \\
\hline
\end{tabular}

All parameters shown in this table are matching criteria for the case-control selection, except the left atrial size and the ejection fraction.

tData given as mean and standard deviation.

t†Data given as median and quartiles. ter measured $41 \pm 6 \mathrm{~mm}$. The median history of AF was 55 months (range 18 months-99 months). Prior attempts of AF ablation had been performed in $20(12 \%)$ patients.

\section{Catheter Ablation Procedure}

In the control group, mapping and ablation were performed as described elsewhere in detail. ${ }^{3,4}$ In brief, circular ablation lesions were deployed in the left atrium around the pulmonary vein funnels using electroanatomical mapping (Carto, Biosense Webster, Diamond Bar, CA, USA). In patients with persistent AF additional ablation lines were placed between the circular lesions and along the roof of the left atrium as well as between the circular lesion and the mitral annulus. The vein-atrium transition was determined combining information from the fluoroscopic cardiac silhouette, impedance changes, and PV-atrium electrogram characteristics. The esophagus was tagged with a Carto catheter. By integrating the localization of the esophagus into the electroanatomically reconstructed left atrial anatomy, potential ablation sites in close vicinity to the esophagus became visible. ${ }^{5}$ Radiofrequency (RF) alternating current was delivered in a unipolar mode between the irrigated tip electrode of the ablation catheter (F-Type, irrigated tip, Navi-Star Thermocool, Biosense Webster) and an external backplate electrode. Based on reduction in electrogram amplitude, the ablation catheter was moved to the next ablation position. Ablation in contact areas between the left atrium and the esophagus was avoided. The standard ablation setting consisted of a preselected catheter tip temperature of $50^{\circ} \mathrm{C}$, a power of $40 \mathrm{~W}$, and a flow rate of $30 \mathrm{~mL} / \mathrm{min}$. At the posterior left atrium near to the esophagus power delivery was reduced to $25 \mathrm{~W}$ and $20 \mathrm{~mL} / \mathrm{min}$. At the anterior aspects of the circumferential ablation lines left atrial wall thickness required individualized power increases of up to $50 \mathrm{~W}$ to achieve line continuity. Due to the risk of popping and tamponade in those situations, the catheter tip was moved along the ablation line instead of being left in one stable position to prevent local tissue overheating.

The endpoint of the procedure was the completion of the intended lesion lines with either complete PV isolation or conduction delay into the PVs. Voltage mapping and pacing maneuvers were performed inside the encircled areas and the PVs to test for remaining PV conduction or complete PV isolation with bidirectional block.

In the case group mapping and ablation followed the same lesion line concept. The same ablation catheter (F-Type, irrigated tip, Navi-Star Thermocool, Biosense Webster) was used with identical catheter settings. However, navigation of the catheter tip was achieved solely through 
bending, stretching, and rotation of a bidirectional steerable sheath (SJM, Agilis). Technical details of the sheath are as follows: inner diameter $8.5 \mathrm{~F}$, outer diameter $13.5 \mathrm{~F}$, total length $71 \mathrm{~cm}$, working length $61 \mathrm{~cm}$, and bidirectional deflectable with a small curl curve $\left(90^{\circ} / 180^{\circ}\right)$. In the group with steerable sheath navigation, the mapping/ablation catheter was handled passively and only advanced or retracted in order to achieve optimal wall contact according to fluoroscopic, electrogram, and tactile feedback (Fig. 1).

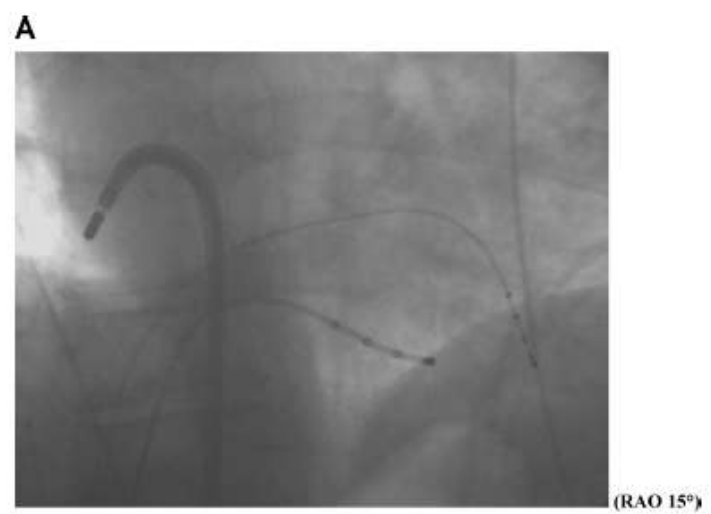

B

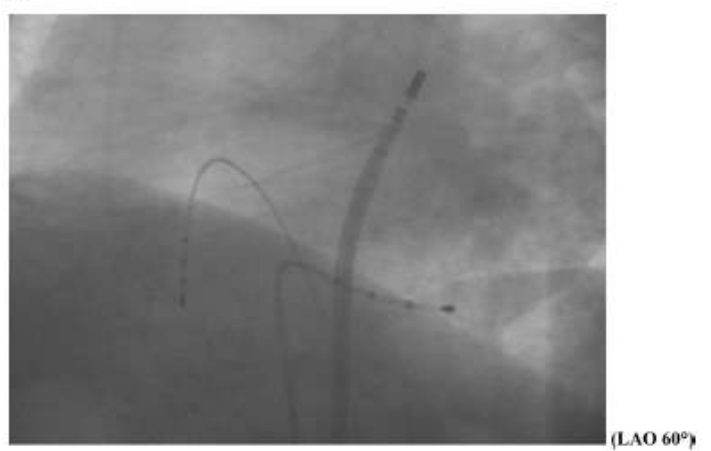

Figure 1. (A) Typical position of streerable sheath and ablation catheter tip underneath the RLPV. (B) Typical position of streerable sheath and ablation catheter tip between LUPV and LAA. Fluoroscopic images illustrating typical positions and curvatures of the steerable sheath while navigating the passively handled ablation catheter ( $A B L)$ toward the ablation target site. In both images a quadripolar steerable $6 \mathrm{~F}$ diagnostic catheter is placed within the coronary sinus (CS) and a quadripolar nonsteerable $4 \mathrm{~F}$ diagnostic catheter is placed in the right ventricular apex (RVA). The two locations illustrated in this figure represent typical ablation areas where mapping and ablation is difficult due to catheter access, catheter stability, and left atrial wall contact. (A) Left atrial wall underneath the right lower pulmonary vein (RLPV). (B) Tissue bridge between the left upper pulmonary vein (LUPV) and the left atrial appendage (LAA).
The following procedural data were collected and compared between the two groups: procedure time, fluoroscopy time, irradiation dose, number of RF pulses, RF burning time, RF energy delivery, and rate of complete PV isolation. The procedure time was measured from the first femoral puncture to the removal of all sheaths. Fluoroscopy time and irradiation dose were automatically monitored by the fluoroscopy system. The RF burning time is the sum of the duration of all single RF pulses in an individual patient. The RF energy delivery is the sum of the energy delivered through all single RF pulses in an individual patient. To obtain that data, for each RF pulse the delivered RF energy was calculated as the product of the average power delivered at the catheter tip and the duration of the pulse.

\section{Postprocedural Care and Follow-Up}

Following patient selection and prior to ablation, a continuous 7-day Holter ECG (Lifecard CF, Del Mar Reynolds Medical Inc., Irvine, CA, USA) was recorded in all patients. The continuous 7-day Holter ECG was repeated immediately after ablation, after 3 months, and after 6 months. In case of symptoms outside the recording periods, patients were advised to contact our institution or the referring physician to obtain an ECG-documentation. AF longer than 30 seconds was considered as an episode of sustained AF recurrence. Recordings of atrial flutter (AFLU) were analyzed separately.

As part of our study protocol, after ablation the antiarrhythmic medication was discontinued and patients received a beta-blocker, if tolerated. In case of early postinterventional AF recurrences within the two postinterventional inhospital days, cardioversion was performed for AF episodes lasting longer than one hour and antiarrhythmic drugs (flecainide or amiodarone) were added for at least 3 months. Afterward the medication was adapted on an individual basis.

Starting the day after the ablation procedure, the patients received an oral anticoagulation with an international normalized ratio of 2.0-3.0. Anticoagulation was discontinued after the 6-month follow-up only in the case of freedom from any documented AF/AFLU recurrences on all serial 7-day Holter ECGs, together with freedom from symptomatic AF episodes in between the Holter recording periods, and additionally, a normal flow velocity in the left atrial appendage on transesophageal echo 6 months after ablation indicating a preserved LA transport function.

In patients with symptomatic postinterventional arrhythmia recurrences refractory to antiarrhythmic drug treatment reablations were performed after 3 months of follow-up only. In the group ablated with steerable sheath navigation 
(cases), all 83 patients have completed the 6-month follow-up. In the group ablated with the nonsteerable sheath (controls), four of the 83 patients $(4.8 \%)$ underwent reablation between 3 and 6 months of follow-up.

\section{Statistics}

The data were tested for normal (Gaussian) distribution using the Kolmogoroff-Smirnov test. Normally distributed continuous variables are presented as mean \pm standard deviation (SD). In case of a non-Gaussian distribution, median and quartiles are given. Categorical variables are expressed as number and percentage of patients.

Differences of continuous normally distributed data between the case and the control group (i.e., procedure time, fluoroscopy time, RF burning time) were tested for statistical significance using the $t$-test for independent samples. In case of continuous data with a nongaussian distribution (i.e., irradiation dose, RF pulses, RF energy delivery), the Mann-Whitney-U test was used.

Differences of categorical data between the case and the control group (i.e., rhythm outcome, complete PV isolation, antiarrhythmic drug usage) were tested for statistical significance using the chi-square test. Differences of antiarrhythmic drug usage before and 6 months after ablation within the case and the control group were tested for statistical significance using the McNemar test.

To study possible predictors for long-term success in the case and in the control group, a binary logistic regression analysis was performed. In this model, the 6 months success (i.e., freedom from $\mathrm{AF}$ and/or AFLU) is the dependent variable. The multivariate influence of age (years), left atrial size (in mm), AF history (month), and the incidence of any structural heart disease, paroxysmal AF, lack of early recurrences, and complete pulmonary vein isolation were analyzed. The coefficient and the odd of each predictor variable are given among with the results of the Wald test for a significant influence. Test results of goodness-offit tests have been added (Cox\&Snell R ${ }^{2}$, HosmerLemeshow test).

All analyses were performed using SPSS for Windows, Release 11.5 (SPSS Inc., Chicago, IL, USA).

A P value of less than 0.05 was considered statistically significant.

Results
Rhythm Outcome
During 7-day Holter before ablation, AF was
documented in $62(75 \%)$ patients in the control
group and $60(72 \%)$ patients in the steerable sheath
group $(\mathrm{P}=0.370)$. During follow-up, patients with

AF recurrences were observed as follows: immediately after ablation $60(72 \%)$ [controls] vs 48 $(58 \%)$ [cases] $(\mathrm{P}=0.051)$; after 3 months $35(42 \%)$ [controls] vs $22(27 \%)$ [cases] $(\mathrm{P}=0.018)$; after 6 months $35(44 \%)$ [controls] vs $19(23 \%)$ [cases] $(\mathrm{P}=0.009)$ (Fig. 2A).

The rate of documented atypical atrial flutter was not significantly different between the two groups at any time during follow-up (Fig. 2B). Comparing the occurrence of any sustained atrial tachyarrhythmia (AF, and/or atrial flutter) between control patients and cases gave the following results: before ablation $62(75 \%)$ vs 60 $(72 \%)(P=0.370)$; after ablation $62(75 \%)$ vs $50(60 \%)(\mathrm{P}=0.048)$; after 3 months $37(45 \%)$ vs $22(27 \%)(\mathrm{P}=0.018)$; after 6 months $37(47 \%)$ vs $21(25 \%)(\mathrm{P}=0.008)$ (Fig. $2 \mathrm{C})$.

\section{Procedural Data}

The total procedure time as measured from the first femoral puncture to the removal of all sheaths measured $143 \pm 30$ minutes for the patients in the control group and $148 \pm 32$ minutes for the patients ablated with steerable sheath navigation $(\mathrm{P}=0.256$ ) (Table II). The fluoroscopy time, irradiation dose, RF burning time, and number of RF pulses were also not significantly different (Table II). Mean procedural RF power [33 $\pm 9 \mathrm{~W}$ vs $41 \pm 4 \mathrm{~W} ; \mathrm{P}<0.0005$ ] and total RF energy delivery $(97,498 \mathrm{~J}(71,649 ; 115,680)$ vs $111,864 \mathrm{~J}$ $(98,065 ; 131,700) ; \mathrm{P}<0.005)$ were significantly reduced in the group with steerable sheath navigation compared to the control group.

Electrical cardioversions due to early AF recurrences within the first two postinterventional in-hospital days were required in $13(16 \%)$ patients of the control group and two (3\%) patients ablated with steerable sheath navigation $(\mathrm{P}=0.003)$.

\section{Complications}

In this study tamponade, thrombembolic events, and femoral vascular access complications (thrombosis or aneurysm) were observed. None of the patients suffered from esophageal fistula, pulmonary vein stenosis, or phrenic nerve palsy. The total number of patients with procedure-related complications was four $(4.8 \%$ ) for the patients ablated with steerable sheath navigation and two $(2.4 \%)$ for the control group $(\mathrm{P}=0.682)$. The rate of tamponade was two $(2.4 \%)$ [cases] vs $0(0 \%)$ [controls] $(\mathrm{P}=0.497)$. The rate of thrombembolic events was $0(0 \%)$ [cases] vs one $(1.2 \%)$ [controls] $(\mathrm{P}=1.0)$. The rate of vascular access complications was two $(2.4 \%)$ [cases] vs one $(1.2 \%)$ [controls] $(\mathrm{P}=1.0)$ 


\section{A}

\section{Rate of AF recurrences during follow-up in case and control group}

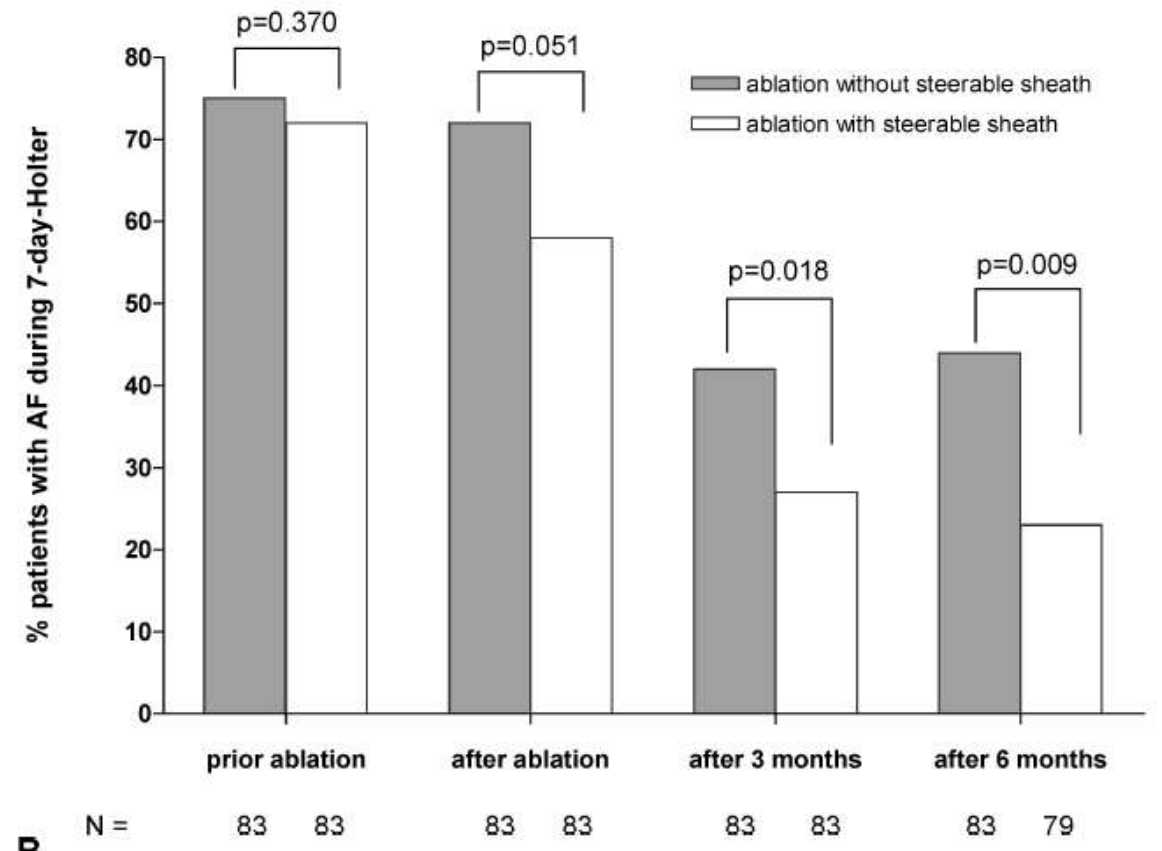

B

Rate of AFLU recurrences during follow-up in case and control group

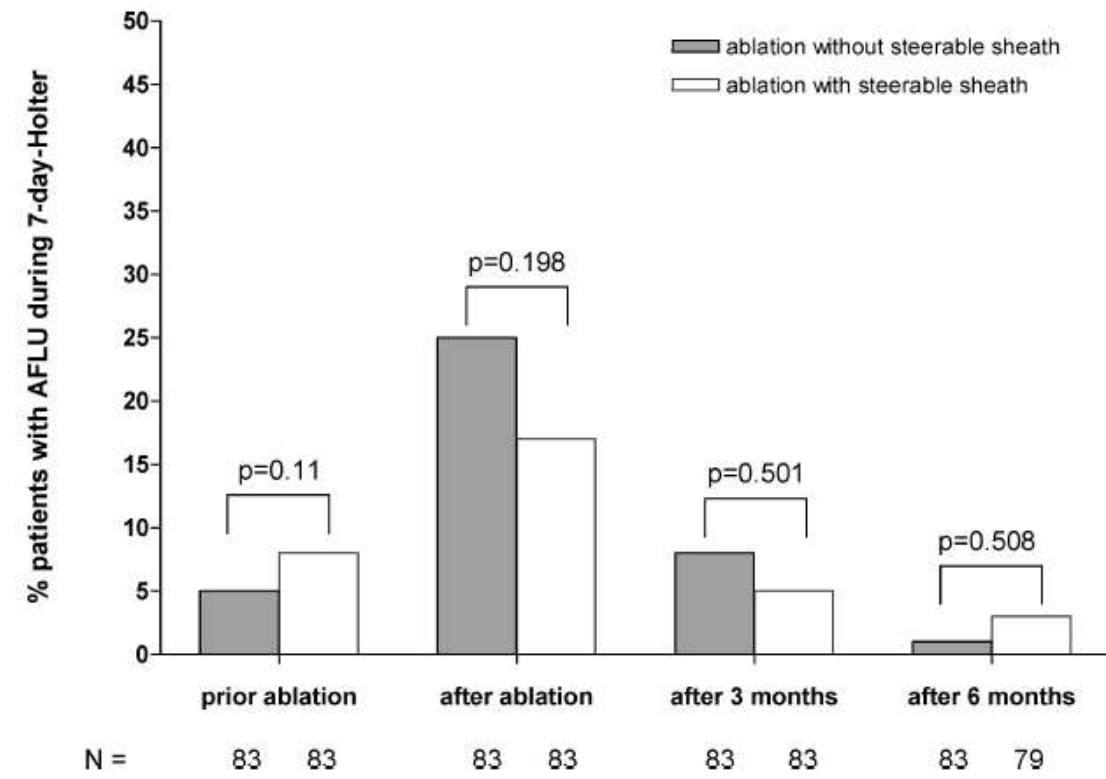

Figure 2. Diagrams illustrating the rhythm outcome on follow-up with serial 7-day Holter ECGs in patients treated with steerable sheath navigation (cases) and in patients treated with a nonsteerable sheath (controls). During each follow-up point the percentage of patients with documented $A F$ recurrences (A), AFLU recurrences (B), and recurrences of AF and/or AFLU (C) is given for each treatment group. The recurrence rates were compared between the two treatment groups using the chi-square test. 
C

Rate of AF and/or AFLU recurrences during follow-up in case and control group

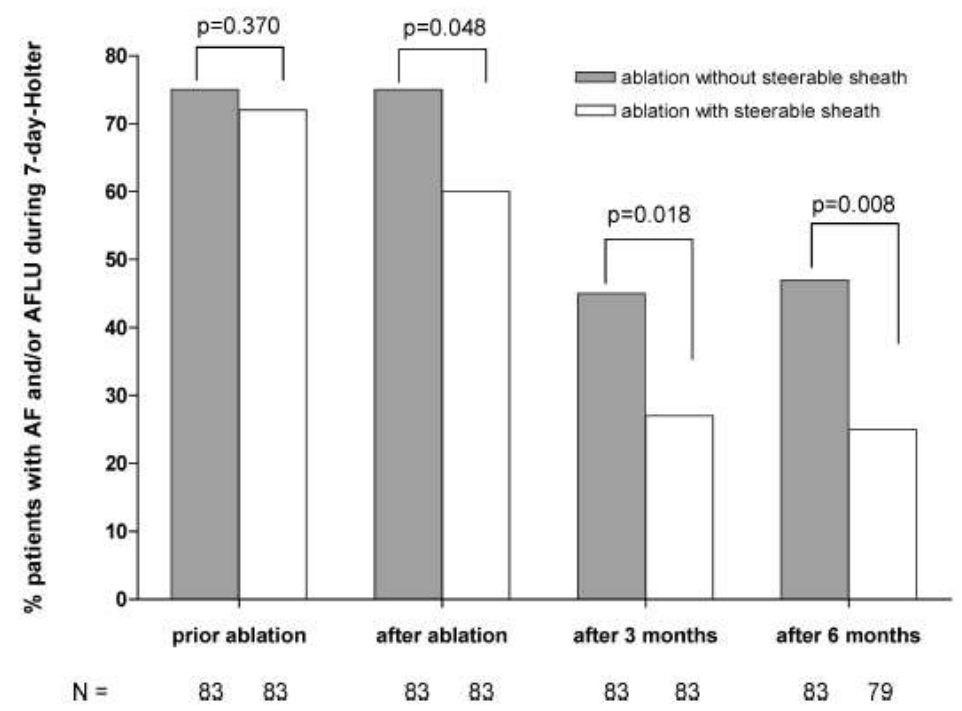

Figure 2. Continued.

\section{Secondary Left Atrial Interventions}

Reablations for symptomatic drug refractory AF recurrences were performed in four $(4.8 \%)$ patients of the case group and $19(22.9 \%)$ of the control group $(\mathrm{P}=0.001)$. Electrophysiological PV assessment revealed incomplete isolation of all PVs after the index procedure in all of these four cases and 19 control patients. Three of the four case patients had complete isolation of the right-sided PVs after the index procedure, which remained isolated at reablation. Among the 19 control patients, only two had isolation of the right upper PV after the index procedure but suffered from reconduction at reablation.

In addition to $\mathrm{AF}$ reablation procedures, two $(2.4 \%)$ patients of the case group and four $(4.8 \%)$

Table II.

Procedural Data for the Group of Patients Treated with Steerable Sheath Catheter Navigation (Cases) and for the Group of Patients Treated with a Nonsteerable Sheath (controls)

\begin{tabular}{|c|c|c|c|}
\hline & Cases $(n=83)$ & Controls $(n=83)$ & $\mathbf{P}$ \\
\hline Procedure time [minutes] $]^{\dagger}$ & $149 \pm 32$ & $143 \pm 29$ & 0.256 \\
\hline Fluoroscopy time [minutes] ${ }^{\dagger \dagger}$ & $21(17 ; 25)$ & $22(16 ; 29)$ & 0.652 \\
\hline Irradiation dose $[\mathrm{cGy} / \mathrm{cm} 2]^{\dagger \dagger}$ & $6,200(3,425 ; 7,775)$ & $7,100(3,950 ; 10,600)$ & 0.128 \\
\hline RF burning time [minutes] $]^{\dagger}$ & $42 \pm 13$ & $40 \pm 12$ & 0.447 \\
\hline Number of RF pulses ${ }^{t \dagger}$ & $30(24 ; 37)$ & $34(25 ; 43)$ & 0.127 \\
\hline Mean procedural RF power $[\mathrm{W}]^{\dagger}$ & $33 \pm 9$ & $41 \pm 4$ & $<0.0005$ \\
\hline $\begin{array}{l}\text { Radiofrequency energy }[\mathrm{J}]^{\mathrm{t \dagger}} \\
\text { Complete pulmonary vein isolatior }\end{array}$ & $97,498(71,649 ; 115,680)$ & $111,864(98,065 ; 131,700)$ & $<0.0005$ \\
\hline Left-sided veins, $n(\%)$ & $58(70)$ & $12(14)$ & $<0.0005$ \\
\hline Right-sided veins, $\mathrm{n}(\%)$ & $64(77)$ & $18(22)$ & $<0.0005$ \\
\hline Left- and right-sided veins, $\mathrm{n}(\%)$ & $43(52)$ & $8(10)$ & $<0.0005$ \\
\hline
\end{tabular}

Continuous normally distributed parameters $\left(^{\dagger}\right)$ were compared between the two groups using the $t$-test for independent samples. Continuous parameters with a nongaussian distribution $\left({ }^{\mathrm{t \dagger}}\right.$ ) were compared using the Mann-Whitney- $\mathrm{U}$ test. Categorical data were compared using chi-square test.

tData given as mean and standard deviation.

${ }^{\dagger}$ Data given as median and quartiles. 
of the control group received an ablation of gaprelated left atrial flutter $(\mathrm{P}=0.682)$. The macrorrentrant circuit was found to be located perimitral $(\mathrm{n}=2)$, through the left atrial roof $(\mathrm{n}=2)$ and around a single PV $(n=2)$. Electrophysiological PV assessment at reablation revealed complete PV isolation in one case patient and reconduction of the left upper PV in the other. All four control patients had PV conduction after the index procedure and before reintervention.

In total, six $(7.2 \%)$ patients of the case group and $23(27.7 \%)$ of the control group needed a left atrial reintervention $(\mathrm{P}=0.001)$.

\section{Antiarrhythmic Drug Use after Ablation}

As part of our study protocol, after ablation the antiarrhythmic medication was discontinued and patients received a $\beta$-blocker, if tolerated. In case of early postinterventional AF recurrences, antiarrhythmic drugs (flecainide or amiodarone) were added for at least 3 months. Afterward the medication was adapted on an individual basis.

Six months after ablation, the rate of antiarrhythmic drug usage was significantly reduced compared with the usage prior to ablation, in both groups (cases: $84 \%$ vs $27 \%(\mathrm{P}=0.001)$; controls: $88 \%$ vs $41 \%(\mathrm{P}=0.001))$. Table III displays the number for class IC and class III drugs separately.

Comparing the usage of $\beta$-blocker and antiarrhythmic medication between patients ablated with a conventional nonsteerable sheath (controls) and patients ablated with steerable sheath navigation (cases) showed a trend toward a reduced rate of antiarrhythmic drug treatment in the case group 6 months after ablation. However, that reduction did not reach statistical significance (Table III).

\section{Predictors for Treatment Success}

Multivariate analyses on predictors for longterm ablation success included patient age, left atrial size, duration of AF history, incidence of any structural heart disease, paroxysmal AF, lack of early recurrences, and complete PV isolation in a binary logistic regression model. Table IV summarizes the respective data. None of the studied parameters showed an influence on treatment success at the 6-month follow-up except the lack of early postinterventional recurrences (Table IV). Accordingly, in both treatment groups the lack of early arrhythmia relapses during the 7-day Holter within the first postinterventional week was highly predictive for long-term success (positive predictive value $94 \%$ in the case group, and $85 \%$ in the control group).

\section{Discussion \\ Main Findings of the Study}

Mapping and ablation of AF crucially depends on stable, reproducible, and reliable access to all desired target sites along the intended linear ablation lesions. A new catheter interventional treatment approach solely using a manually controlled steerable sheath for catheter navigation improved the outcome of circumferential left atrial PV ablation with respect to freedom from any atrial tachyarrhythmia (atrial fibrillation and/or left atrial flutter) after a single left atrial procedure from $53 \%$ to $75 \%$ at the 6 -month follow-up. Procedural duration and rate of complications were not increased.

\section{Procedural Aspects}

Acknowledging the relevance of initiating triggers and perpetuating substrate as the two major pathophysiological AF cornerstones, curative catheter interventional treatment approaches have evolved from fluoroscopy-based Lasso-guided segmental PV isolation procedures into complex left atrial linear and circumferential lesion line

Table III.

Table Showing the Usage of Class IC and Class III Antiarrhythmic Drugs Before and 6 Months after Ablation in the Group of Patients Treated with Steerable Sheath Navigation (cases) and in the Group of Patients Treated Conventionally (controls)

\begin{tabular}{|c|c|c|c|c|}
\hline & & Before Ablation & 6 Months After & \\
\hline \multirow[t]{2}{*}{ Class Ic } & Cases $(n=83)$ & $46(55 \%)$ & $14(17 \%)$ & $P<0.0005$ \\
\hline & Controls $(n=79)$ & $\begin{array}{c}46(58 \%) \\
P=0.662\end{array}$ & $\begin{array}{l}18(23 \%) \\
P=0.449\end{array}$ & $P<0.0005$ \\
\hline \multirow[t]{2}{*}{ Class III } & Cases $(n=83)$ & $24(29 \%)$ & $8(10 \%)$ & $P=0.007$ \\
\hline & Controls $(n=79)$ & $\begin{array}{l}24(30 \%) \\
P=0.897\end{array}$ & $\begin{array}{l}14(18 \%) \\
P=0.185\end{array}$ & $P=0.049$ \\
\hline
\end{tabular}

Changes of antiarrhythmic drug usage before and after ablation were tested among cases and among controls for each antiarrhythmic drug separately, using the McNemar test. Differences of antiarrhythmic drug usage between the two treatment groups were tested before and after ablation for each antiarrhythmic drug separately, using the chi-square test. 
Table IV.

Possible Predictors for 6 Months Success (Freedom from Any Atrial Tachyarrhythmia)

\begin{tabular}{lccccc}
\hline 6 Months Success & Yes $(\mathbf{n}=104)$ & No $(\mathbf{n}=62)$ & B & Odds $\left(\mathrm{e}^{\mathrm{b}}\right)$ & Wald P Value \\
\hline Age (years) & $55 \pm 10$ & $57 \pm 8$ & 0.042 & 1.043 & 0.250 \\
LA size (mm) $_{\text {AF history (months) }}^{\dagger}$ & $42 \pm 10$ & $42 \pm 6$ & -0.173 & 0.841 & 0.637 \\
Structural heart disease & $56(48 ; 63)$ & $58(52 ; 64)$ & 0.002 & 1.002 & 0.385 \\
Paroxysmal AF & $45(43 \%)$ & $31(50 \%)$ & 0.484 & 1.623 & 0.411 \\
Complete PV isolation & $85(82 \%)$ & $47(76 \%)$ & 0.076 & 1.079 & 0.924 \\
Lack of early recurrences $^{\ddagger}$ & $36(34 \%)$ & $15(24 \%)$ & -0.016 & 0.984 & 0.985 \\
\hline
\end{tabular}

Data are given as absolute metric values or frequencies, coefficient (b) of the regression curve, odds $\left(e^{b}\right)$ and $P$-values of Wald test for statistical significance. Cox\&Snell $R^{2}=0.251$. Hosmer-Lemeshow test for goodness-of-fit $P=0.862$.

${ }^{\dagger}$ Data given as median and quartiles.

ҒAs measured during postinterventional 7-day Holter ECG.

$\mathrm{e}=$ Euler's number.

concepts. In order to place the lines in the intended manner continuously and transmural, these primarily anatomically based approaches require an excellent three-dimensional orientation within the true anatomy on one hand and a stable, reproducible, and reliable reach to all desired ablation target sites on the other. With respect to the second point, conventional ablation approaches with a nonsteerable sheath and a steerable ablation catheter have their limitations. Therefore, several attempts are being made to improve threedimensional catheter navigation, catheter stability, and left atrial wall contact. Robotic magnetic catheter navigation has been described to be used for AF ablation, recently. ${ }^{6}$ However, the technical requirements together with the related costs prevent a widespread application of that technology in the field of AF catheter ablation. Additionally, so far no data exist comparing that approach against a conventional manually performed circumferential PV ablation. Another development in the area of improved catheter navigation has been published with a robotic catheter remote control system, ${ }^{7}$ which in principle represents a roboticcontrolled steerable sheath technology. However, so far no comparative data have been published on the efficacy of that technology for the treatment of patients with AF. Besides, together with the previous system and any robotic-controlled technology it shares the disadvantage of the loss of tactile feedback during mapping and ablation, which can be important from the side of efficacy as well as from the side of complications.

Our study is the first one to describe the use of a manually controlled steerable sheath for mapping and ablation of AF according to the line concept of circumferential left atrial PV ablation. Ad- ditionally, as a case-control analysis, for the first time it provides a thorough comparison against a conventional nonsteerable sheath approach with respect to procedural data, data on efficacy, and data on complications.

\section{Technical Aspects}

In our study the intervention time, fluoroscopy time, irradiation dose, and RF burning time were not significantly different between both groups. However, patients ablated with steerable sheath navigation showed a tendency toward a reduced number of RF pulses delivered during the whole procedure, a significantly reduced mean RF power, a significantly reduced total RF energy delivery, and a significantly increased rate of complete isolation of all encircled PV funnels after purely anatomically based ablation lines. The significantly reduced mean RF power together with the reduced total RF energy delivery indicates that the preselected target temperature at the catheter tip is achieved earlier with less energy needed to be transferred into the tissue. Together with the trend toward a reduced number of RF pulses and the significantly higher rate of complete PV isolation with otherwise identical line concepts and comparable procedural data, these parameters argue for improved catheter stability with improved left atrial wall contact and a more efficient energy delivery by using a steerable transseptal sheath.

Further technical issues of steerable sheath navigation relate to the transseptal puncture and the steerable sheath handling within the left atrium. In our entire patients direct transseptal puncture through the steerable or nonsteerable sheath provided direct access into the left atrium. Though having a larger outer diameter transseptal 
puncture with the steerable sheath was successful and without complications in all patients.

Contrary to the nonsteerable sheath group the steerable sheath was used within the left atrium during the entire procedure. The ablation catheter itself was handled passively, and only advanced or retracted in and out the sheath to achieve optimal wall contact according to the map, and according to electrogram, fluoroscopic, and tactile information. This approach carried two significant benefits. First, it improved catheter stability and allowed for precise and well controlled catheter tip handling within the range of millimeters along the intended ablation line. Furthermore, the precise navigation of the catheter tip provided the basis for reliable pace- and voltage mapping inside the complex three-dimensional PV antrum anatomies to detect gaps within the ablation line and to improve achievement of complete PV isolation with a single sheath/catheter approach. Second, the pressure that could be applied through the tip of the ablation catheter was higher. This was needed in areas with thicker left atrial musculature (usually anterior to the left and rightsided PVs).

\section{Safety Aspects}

Access with a larger transseptal sheath and ablation with more catheter tip pressure raises safety concerns. In our study none of the patients suffered from esophageal fistula, PV stenosis, or phrenic nerve palsy. The rate of tamponades, femoral access complications, and thromboembolic events observed in our series closely matches previous data on complication rates published from highly experienced centers. ${ }^{8}$ In the steerable sheath group slightly more tamponades and femoral access complications could be observed. In the control group slightly more thromboembolic events occurred. In summary, the rate of complications was not significantly different between the two groups in total and for the specific complication separately.

The size of the sheath can especially be of concern at the vascular access site and at the transseptal puncture site. In order to minimize vascular damage at the femoral access, we have used any long sheath (steerable or nonsteerable) within a short femoral access sheath. This way no significant difference in vascular access complications could be found. Seen for the transseptal access, a single puncture with a steerable sheath produces a significantly smaller hole in the atrial septum as compared to procedures with multiple nonsteerable transseptal punctures (Lasso-guided techniques) or compared to any left atrial access with balloon technologies. On follow-up with transesophageal echo 6 months after the procedure, in all patients the transseptal puncture site was reoccluded.

\section{Aspects of Efficacy}

AF catheter ablation does not result in a simple binary outcome. Measurement and publication of ablation success largely depend on the investigator's definitions and the intensity of the followup strategy used. Currently, serial 7-day Holter ECGs and repetitive transtelephonic ECG recordings represent the two gold standards for an objective postinterventional follow-up and assessment of ablation success. ${ }^{4,9-11}$ Accordingly, the patients in our study were followed with serial 7-day Holter ECG. The intensity of that follow-up strengthens our data. Concordantly to previous publications with the same ablation line concept and a similar follow-up, in the control group the success rate after a single left atrial procedure showed to be $56 \%$ freedom from AF after 6 months. ${ }^{9-11}$ Using manually controlled steerable sheath navigation increased that number significantly to $77 \%$. Taking the occurrence and documentation of atypical left atrial flutter into consideration and defining ablation success as freedom from any atrial tachyarrhythmia (AF and/or AFLU), after a single left atrial procedure and 6 months of follow-up the success rate increased from $53 \%$ in the control group to $75 \%$ in the steerable sheath group.

Other postinterventional parameters further support the picture of increased efficacy of AF ablation using catheter navigation through a manually controlled steerable sheath. The rate of electrical cardioversions due to early AF recurrences within the first two postinterventional in-hospital days significantly dropped from $16 \%$ to $3 \%$. That is noteworthy given the high predictive power of early postinterventional arrhythmia recurrences to predict long-term success, as discussed further down.

Also the rate of left atrial reablations for recurrences of AF or AFLU was significantly lower in the steerable sheath group. In general AF reablations were performed in case of symptomatic drug refractory AF recurrences after 3 months of follow-up only. In the control group four patients were reablated between 3 and 6 months of followup and 15 patients thereafter. In contrary, in the steerable sheath group four patients were reablated after 6 months of follow-up only. Additionally gap related left atrial flutter had to be ablated in four patients of the control group and two patients of the steerable sheath group. In total, the rate of secondary left atrial procedures significantly dropped from $28 \%$ in the control group to $7 \%$ in the steerable sheath group.

\section{Predictors for Success}

Currently, controversy is still going on to find parameters possibly predicting long-term 
success after left atrial circumferential PV ablation. . $^{2,4,12,13}$

Therefore, in our study we analyzed the multivariate influence of age, left atrial size, AF history, and the incidence of any structural heart disease, paroxysmal AF, lack of early recurrences, and complete pulmonary vein isolation on 6 months success (i.e., freedom from AF and/or AFLU). None of these parameters were able to predict long-term success except the presence of early arrhythmia recurrences during the 7-day Holter ECG within the first postinterventional week. Lack of early postinterventional recurrences had a positive predictive power for 6 months success of $94 \%$ in the steerable sheath group and of $85 \%$ in the control group.

It is interesting to note that despite a significant increase in the rate of complete PV isolation among patients treated with steerable sheath navigation, PV isolation was not predictive for longterm success. In contrary, among patients who were clearly not isolated despite usage of steerable sheath navigation ( $\mathrm{n}=40$ ), the 6 months success rate was still $70 \%$. In that sense our study supports data previously published on efficacious LA ablation concepts using nonisolating linear ablation lines within the left atrium on purpose. ${ }^{13,14}$ Together with the observation of similar ablation outcomes in patients with paroxysmal and persistent AF, that suggests a predominant effect of the ablation concept on AF substrate modification as compared to AF trigger elimination.

\section{Study Limitations}

Limitations relate to the monocentric and retrospective study design with a historical casecontrol analysis. We have tried to compensate for that limitation with the two treatment groups being well matched with respect to patient and arrhythmia characteristics.

Due to the fact that the patients with steerable sheath navigation were ablated later than the patients from the control group, operator experience can be seen as a further bias. However, all ablations within the control group were performed by two highly experienced operators (H.K. and G.H.) with experience from more than 100 procedures beforehand for each of them. In contrary, $53 \%$ of the ablations with steerable sheath nav- igation were performed by two less-experienced operators (J.L. and C.P.), who were new to the technique of left atrial AF ablation. Therefore, if a limitation due to operator experience has to be assumed, that would create a bias against the steerable sheath group, and by that means support our results.

\section{Clinical Implications}

Lack of stable, reproducible, and reliable access to all desired ablation target sites has been identified as one of the major limitations for the efficacy of circumferential left atrial PV ablation. Areas of difficulty can be found especially between the left upper pulmonary vein and the left atrial appendage and underneath the right lower pulmonary vein. Targeting that limitation robotic magnetic catheter navigation, robotic-controlled steerable sheath technology, and manually controlled steerable sheath technology have been developed. The results of our study show that a new AF mapping and ablation approach based on catheter navigation solely through a manually controlled steerable sheath with passive handling of the ablation catheter itself resulted in a highly significant increase of ablation efficacy at similar intervention times and a similar complication rate. Compared to the robotic controlled technologies the manually controlled steerable sheath carries the advantages of simplicity, cost-effectiveness, tactile feedback for the physician, and the availability of suitable irrigated catheter designs. Future development of the manually controlled steerable sheath technology, for instance, with an increased range of movement directions, appears desirable. Certainly, confirmation of our results in a multicenter, prospective, randomized trial is necessary.

\section{Conclusion}

An AF mapping and ablation approach using a manually controlled steerable sheath for catheter navigation improved the outcome of circumferential left atrial PV ablation at similar intervention times and similar complication rates. The success rate after a single left atrial intervention and 6 months of follow up increased from $53 \%$ to $75 \%$ freedom from any atrial tachyarrhythmia (AF and/or AFLU). Lack of early postinterventional arrhythmia recurrences was the only but powerful predictor for long-term ablation success.

\section{References}

1. Haissaguerre M, Jais P, Shah DC, Takahashi A, Hocini M, Quiniou $\mathrm{G}$, Garrigue S, et al. Spontaneous initiation of atrial fibrillation by ectopic beats originating in the pulmonary veins. N Engl J Med 1998; 339:659-666.

2. Pappone C, Oreto G, Rosanio S, Vicedomini G, Tocchi M, Gagliotta F, Salvati A, et al. Atrial electoanatomic remodelling after circumferential radiofrequency pulmonary vein ablation. Efficacy of an anatomic

approach in a large cohort of patients with atrial fibrillation. Circulation 2001; 104:2539-2544

3. Oral H, Scharf C, Chugh A, Hall B, Cheung P, Good E, Veerareddy S, et al. Catheter ablation for paroxysmal atrial fibrillation: Segmental pulmonary vein ostial ablation versus left atrial ablation. Circulation 2003; 108:2355-2360.

4. Kottkamp H, Tanner H, Kobza R, Schirdewahn P, Dorszewski A, 
Gerds-Li JH, Carbucicchio C, et al. Time course and quantitative analysis of atrial fibrillation episode number and duration after circular plus linear left atrial ablation; Trigger elimination or substrate modification, early or delayed cure? J Am Coll Cardiol 2004; 44:869877.

5. Piorkowski C, Hindricks G, Schreiber D, Tanner H, Weise W, Koch A, Gerds-Li JH, et al. Electroanatomic reconstruction of the left atrium, pulmonary veins, and esophagus compared with the "true anatomy' on multislice computed tomography in patients undergoing catheter ablation of atrial fibrillation. Heart Rhythm 2006:3:317327.

6. Pappone C, Vicedomini G, Manguso F, Gugliotta F, Mazzone P, Guletta S, Sora N, et al. Robotic magnetic navigation for atrial fibrillation ablation. J Am Coll Cardiol 2006; 47:1390-1400.

7. Saliba W, Cummings JE, Oh S, Zhang Y, Mazgalev TN, Schweikert RA, Burkhardt JD, et al. Novel robotic catheter remote control system: Feasibility and safety of transseptal puncture and endocardial catheter navigation. J Cardiovasc Electrophysiol 2006; 17:11021105.

8. Hsu LF, Jais P, Hocini M, Sanders P, Scavee C, Sacher F, Takahashi $\mathrm{Y}$, et al. Incidence and prevention of cardiac tamponade complicating ablation for atrial fibrillation. Pacing Clin Electrophysiol 2005; 28(Suppl 1):106-109.

9. Hindricks G, Piorkowski C, Tanner H, Kobza R, Gerds-Li JH, Carbuciccio C, Kottkamp H. Perception of atrial fibrillation before and after radiofrequency catheter ablation: Relevance of asymptomatic arrhythmia recurrence. Circulation 2005; 112:307-313.

10. Piorkowski C, Kottkamp H, Tanner H, Kobza R, Nielsen JC, Arya A, Hindricks G. Value of different follow-up strategies to assess the efficacy of circumferential pulmonary vein ablation for the curative treatment of atrial fibrillation. J Cardiovasc Electrophysiol 2005; $16: 1286-1292$.

11. Karch M, Zrenner B, Deisenhofer I, Schreieck J, Ndrepepa G, Dong J, Lamprecht K, et al. Freedom from atrial tachyarrhythmias after catheter ablation of atrial fibrillation: A randomized comparison between 2 current ablation strategies. Circulation 2005; 111:28752880.

12. Ouyang F, Bansch D, Ernst S, Schaumann A, Hachiya H, Chen M, Chun J, et al. Complete isolation of left atrium surrounding the pulmonary veins: New insights from the double-Lasso technique in paroxysmal atrial fibrillation. Circulation 2004; 110:2090-2096.

13. Kottkamp H, Hindricks G, Autschbach R, Krauss B, Strasser B, Schirdewahn P, Fabricius A, et al. Specific linear left atrial lesions in atrial fibrillation: Intraoperative radiofrequency ablation using minimally invasive surgical techniques. J Am Coll Cardiol 2002; 40:475-480.

14. Oral H, Chugh A, Good E, Igic P, Elmouchi D, Tschopp DR, Reich SS, et al. Randomized comparison of encircling and nonencircling left atrial ablation for chronic atrial fibrillation. Heart Rhythm 2005; 2:1165-1172. 


\subsection{Entwicklungen zu Katheterstabilität und objektivierbarem Wandkontakt}

4.2.2. Erste Validierung einer Impedanz-basierten Messung des KatheterGewebe Kontaktes im Menschen

Zitierweise:

Christopher Piorkowski, M.D., Haris Sih, Ph.D., Philipp Sommer, M.D., Stephan P. Miller, B.S., Thomas Gaspar, M.D., Liane Teplitsky, M.S., and Gerhard Hindricks, M.D., Ph.D.

First in Human Validation of Impedance-Based Catheter Tip-to-Tissue Contact Assessment in the Left Atrium

J Cardiovasc Electrophysiol, 2009 Jul 7, Vol. pp. 1-8, [Epub ahead of print]. 


\title{
First in Human Validation of Impedance-Based Catheter Tip-to-Tissue Contact Assessment in the Left Atrium
}

\author{
CHRISTOPHER PIORKOWSKI, M.D., ${ }^{*}$ HARIS SIH, PH.D.,† PHILIPP SOMMER, M.D., ${ }^{*}$ \\ STEPHAN P. MILLER, B.S., $\dagger$ THOMAS GASPAR, M.D., ${ }^{*}$ LIANE TEPLITSKY, M.S., $\dagger$ \\ and GERHARD HINDRICKS, M.D., PH.D.*
}

From the * Department of Electrophysiology, University of Leipzig, Heart Center, Leipzig, Germany; and †St. Jude Medical, AF Division, Department of Therapy Development, St. Paul, Minnesota, USA

\begin{abstract}
Impedance-Based Catheter Contact Assessment. Background: In this study, a new method of contact assessment based on the measurement of the local electrical properties at the catheter tip-to-tissue interface was validated in a blinded fashion in vivo in the human left atrium.

Methods: Using a 3-terminal circuit model, local resistance and reactance between catheter tip and tissue surface were measured and combined in an electrical coupling index (ECI). Twelve patients undergoing atrial fibrillation (AF) catheter ablation were included in this study. The catheter was placed in the left atrium at various levels of contact. Blinded to the physician, measurements of electrogram amplitudes, pacing thresholds, and impedances at the catheter tip-to-tissue interface were performed.

Results: As the catheter went from noncontact to contact, ECI increased from $118 \pm 15$ to $145 \pm 24$ $(\mathrm{P}<0.0001)$, electrogram amplitudes increased from $0.14 \pm 0.16$ to $2.0 \pm 1.9 \mathrm{mV}(\mathrm{P}<0.0001)$, and pacing thresholds decreased from $13.9 \pm 3.1$ to $3.1 \pm 2.0 \mathrm{~mA}(\mathrm{P}<0.0001)$. ECI was significantly higher in vascular tissue as compared with trabeculated and smooth myocardium. Patch orientation, operator, body mass index, or clinical type of AF had no influence on ECI values. On a patient-by-patient analysis, true contact/noncontact locations showed a mean ECI difference of $32.7 \pm 11.6$ units (95\% CI 25.8-39.6). A cut-off value of 5 ECI units was able to separate contact from noncontact with $97 \%$ sensitivity and $95 \%$ specificity.

Conclusion: Measurement of local impedances between catheter tip and tissue is feasible to reproducibly describe electrical catheter contact within the left atrium in a clinical setting of AF catheter ablation. (J Cardiovasc Electrophysiol, Vol. pp. 1-8)
\end{abstract}

\section{Introduction}

Radiofrequency (RF) catheter ablation represents an established curative therapy for cardiac arrhythmias. The quality of catheter tip-to-tissue contact plays a critical role in ablation safety and efficacy. Electrophysiologists have traditionally used a combination of qualitative measures such as tactile feedback, fluoroscopic visualization, and electrical feedback to assess contact. More recently, sensors are being incorporated into catheter systems to measure the force applied between the catheter tip and tissue..$^{1,2}$

While force sensors may provide additional feedback for catheter manipulation, force does not directly measure how well electrical energy is coupled between catheter tip and tissue. For RF ablation, a measure of electrical coupling may

This study was supported by a restricted grant from St. Jude Medical. Liane Teplitsky, M.S., Stephan P. Miller, B.S., and Haris Sih, Ph.D., are employees of the Department of Therapy Development of St. Jude Medical.

Dr. Hindricks reports serving as a consultant or on the advisory board of St. Jude Medical.

Address for correspondence: Christopher Piorkowski, M.D., Department of Electrophysiology, University of Leipzig, Heart Center, Strümpellstrasse 39,04289 Leipzig, Germany.Fax: +49-3418651460; E-mail: piorkowskic@ yahoo.de

Manuscript received 11 January 2009; Revised manuscript received 31 May 2009; Accepted for publication 1 June 2009.

doi: $10.1111 / \mathrm{j} .1540-8167.2009 .01552 . x$ be more relevant to ablation safety and efficacy, and in fact, ablation systems provide rudimentary coupling information through ablation impedance. This impedance, however, is a global impedance measured between the catheter tip and a body-surface electrode. A local measure of impedance specific to the catheter tip-to-tissue interface may be a more clinically relevant measure. A 3-terminal circuit model measuring the local impedance at the catheter tip-to-tissue interface has been developed and evaluated in an animal model, recently. ${ }^{3}$

For the first time, this study validated the ability to assess electrical tissue contact by measuring local impedances at the catheter tip-to-tissue interface in the human left atrium.

\section{Methods}

\section{EnSite Contact ${ }^{\mathrm{TM}}$ System}

EnSite Contact ${ }^{\mathrm{TM}}$ is a hardware and software system that interfaces with the EnSite NavX ${ }^{\mathrm{TM}}$ navigation and visualization technology ("EnSite NavX system", St. Jude Medical, St. Paul, MN, USA). The EnSite Contact system employs a 3-terminal circuit model to isolate and measure the complex impedance at the catheter tip-to-tissue interface. Impedance is a complex number composed of resistance $(\mathrm{R})$ on the real axis and reactance $(\mathrm{X})$ on the imaginary axis. Note that the magnitude of $\mathrm{X}$ is inversely proportional to the magnitude of the capacitance. Capacitance in a physiologic system is due to the cellular structure, where the semipermeable lipid bilayer cell wall creates a charge gradient within the cell that forms a capacitor-like structure. From the measured complex 
Figure 1. Graphical user interface for the EnSite Contact ${ }^{\mathrm{TM}}$ system. Electrical coupling index $(E C I)$ is displayed through the scrolling coupling waveform, through the coupling meter, and through the colorcoded coupling beacon.

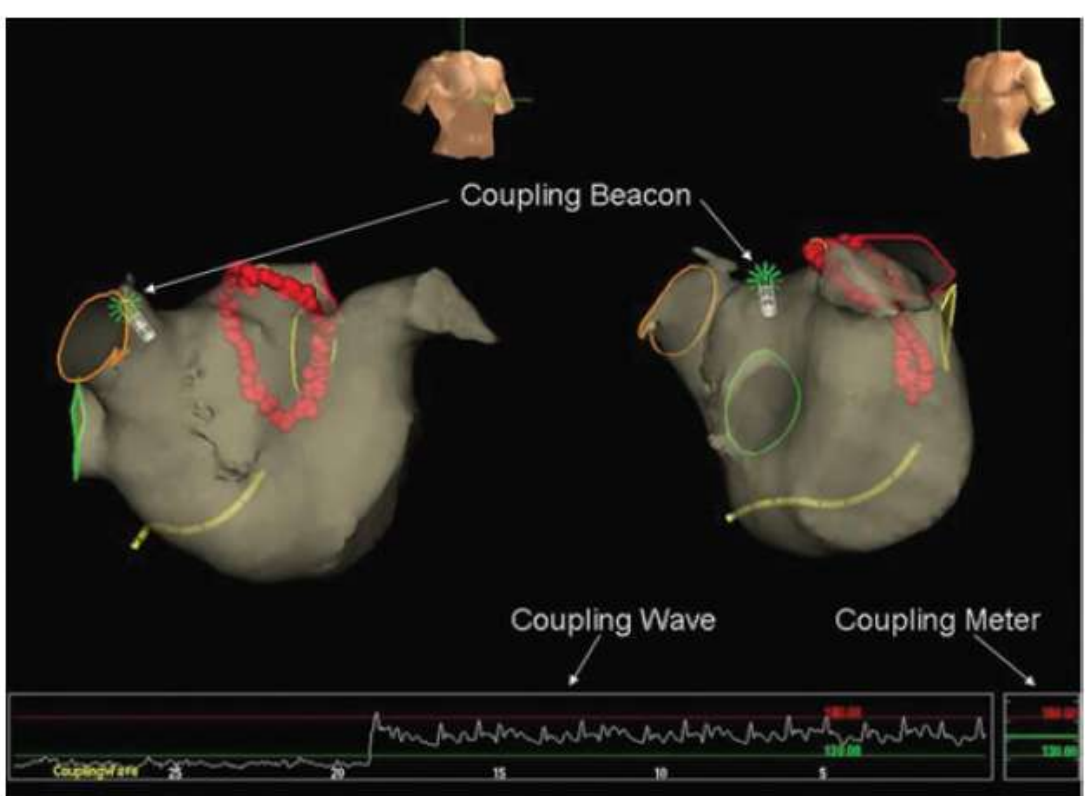

\section{Study Design}

This study was a blinded, prospective, single-center study in humans to evaluate the feasibility of using the local complex impedance as a novel form of electrical feedback describing catheter tip-to-tissue contact. The study was approved by the Ethics Committee of the University of Leipzig, Germany.

Patients with previously diagnosed atrial fibrillation (AF) undergoing an ablation procedure were included in this study. Prior to the ablation procedure, physicians placed the catheter in the left atrium at various levels of contact. Blinded to the physician measurements of electrogram amplitudes, pacing thresholds, and impedances at the catheter tip-to-tissue interface were performed. Additionally, 2 body-surface patch configurations for measuring the complex impedance were assessed: patches placed on the dorsal aspect of the neck and the medial aspect of the left leg; and patches placed approximately midline on the ventral and dorsal aspects of the torso at the level of the heart.

\section{Mapping and Ablation Procedure}

As described elsewhere in detail, 3-dimensional (3D) anatomical orientation was obtained through the integration of 3D computed tomography (CT) images alone without atrial chamber reconstructions. ${ }^{4}$ Briefly, the pulmonary veins (PVs) served as the main structures to register the preacquired 3D CT image into the real-time mapping system (EnSite NavX system). Further catheter manipulation and electrophysiological measurements were performed within the registered 3D CT anatomy.

Patients in AF at the beginning of the procedure were electrically cardioverted to sinus rhythm. The ablation procedure for paroxysmal and persistent AF patients was similar to that previously described ${ }^{4-7}$ A conventional irrigated, 7 Fr ablation catheter with a 4-mm-tip electrode (St. Jude Medical) was used for mapping, electrical contact assessment, and RF ablation $\left(50^{\circ} \mathrm{C}, 40 \mathrm{~W}, 30 \mathrm{~mL} /\right.$ minute $)$.

A temperature probe in the esophagus (FIAB sensitherm, St. Jude Medical, Florence, Italy) at the level of the left 
A

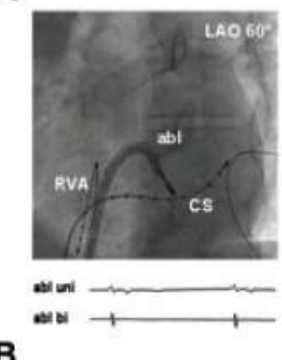

B

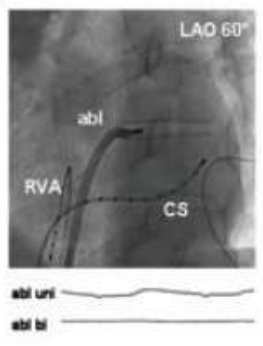

C

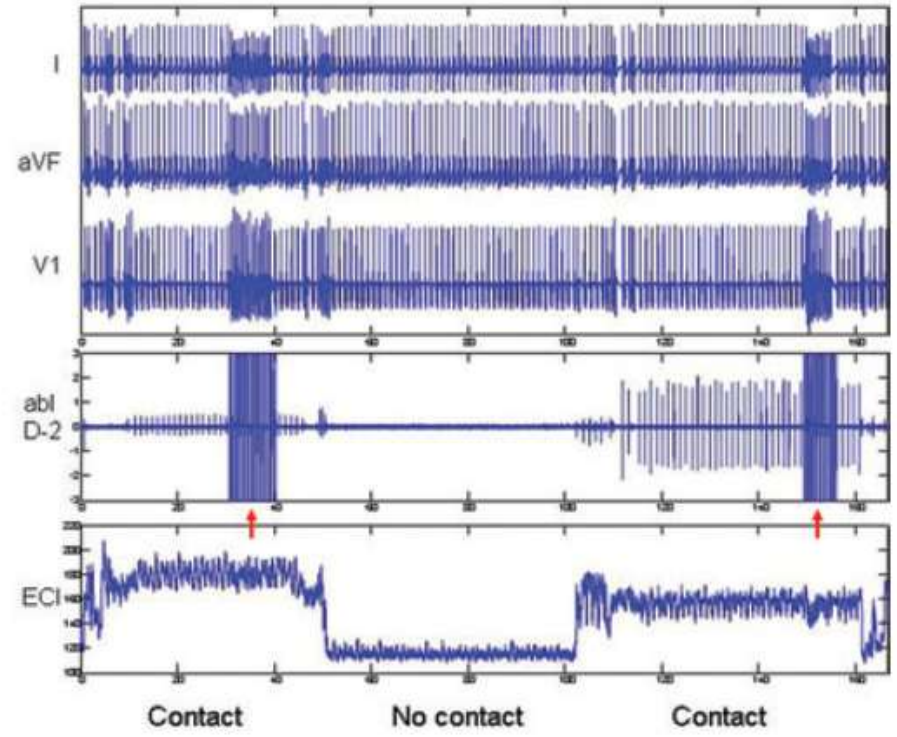

Figure 2. Examples of unambiguous noncontact and unambiguous contact locations in the left atrium on fluoroscopy, local electrogram, and ECI. (A) Unambiguous contact of the tip of the ablation catheter to the endocardial tissue surface at the atrial side of the inferior mitral annulus. Fluoroscopy shows tension on the ablation catheter and almost direct contact between the endocardially positioned ablation catheter and the epicardially positioned CS catheter. Electrogram recordings from the tip of the ablation catheter show sharp bipolar signals. The ST segment of the unipolar signal is not yet elevated (which would be a classical sign of excessive contact). (B) Unambiguous noncontact of the tip of the ablation catheter. The catheter is positioned in the free space of the left atrial body and directed towards the mitral valve. Electrogram recordings from the tip of the ablation catheter do not show any local activity, only unipolar low-voltage far field from the left ventricle. (C) Example of the ECI reading as the catheter is moved between the contact and the noncontact position. Note the robustness of ECI during atrial pacing (red arrows). $C S=$ coronary sinus catheter; $R V A=$ right ventricular apex catheter; abl $=$ ablation catheter.

atrium tagged the esophageal location and provided intraesophageal temperature feedback during the procedure. Near to the esophagus, power delivery was reduced to $25 \mathrm{~W}$ and $20 \mathrm{~mL} / \mathrm{minute}$, and further adapted according to the actual temperature increase.

\section{Data Acquisition}

Blinded to the physician for each of the various catheter contact positions, average values of the complex impedance and the electrogram amplitudes from the ablation catheter were recorded over 5 seconds. Electrogram amplitudes were calculated as the peak-to-peak amplitude of the $32-300 \mathrm{~Hz}$ bipolar signal from the distal 2 electrodes on the ablation catheter. At the same location and time permitting, bipolar pacing thresholds were measured. The various $3 \mathrm{D}$ locations of contact assessment were stored on the EnSite NavX System available for later data review. Contact assessment was performed in viable myocardium only. Scar areas were not used for contact analysis. Scar was defined by the lack of local bipolar electrograms together with the lack of atrial capture despite adequate mechanical contact.

For each patient, the physician placed the ablation catheter in the left atrium in up to 4 areas of unambiguous "noncontact" and up to 4 areas of unambiguous "contact." Additionally, in several (minimum of 6) different left atrial locations, the operator positioned the catheter in "light," "moderate," "firm," or "no contact." The physician determined contact through the combination of fluoroscopy, tactile feedback from the catheter, as well as unipolar and bipolar electrogram recordings. Figure 2 shows typical examples of fluoroscopic images taken during unambiguous noncontact and contact locations. Measurements were also made in vascular, smooth, or trabeculated tissue. Finally, recordings at the beginning and end of the ablation procedure assessed stability of the complex impedance.

\section{Statistics}

Parameters were summarized in terms of means and standard deviations. The Jarque-Bera test was used to test for data normality, and the Levene test was used to test for data homoscedasticity. For normally distributed data with equal variance, Student's $t$-tests or 1-way analysis of variance (ANOVA) tests were used to compare measures across groups. For multigroup comparisons, the Tukey post hoc test was used to determine pairwise differences. N-way ANOVA tests were used to determine significance of multiple variables in parameters, with Tukey post hoc tests to determine relevant pairwise differences. For data that were not normally distributed or had unequal variance, the Wilcoxon signedrank test was used to compare between 2 groups of data. For comparisons across groups, the mathematical inverse of the data was taken to pass the homoscedasticity assumption. If the transformed data still did not pass the normality assumption, the Kruskal-Wallis test was used in place of the 1-way ANOVA.

An analysis was performed to determine ECI values and ECI changes between true contact and true noncontact locations on a patient-specific basis. To accomplish this, receiver operating characteristic (ROC) analysis was performed to determine the sensitivity and specificity for differentiating contact from noncontact. ECI obtained during unambiguous, moderate, or firm contact were grouped together and 
TABLE 1

Patient Demographics

\begin{tabular}{lc}
\hline Age & $63 \pm 10$ years \\
Sex & $9 \mathrm{M}, 3 \mathrm{~F}$ \\
BMI & $26.8 \pm 2$ \\
Paroxysmal / persistent AF & $10 / 2$ \\
Arterial hypertension & 4 \\
Coronary artery disease & 1 \\
Lone atrial fibrillation & 6 \\
Prior CTI ablation & 1 \\
Prior AF ablation & 2 \\
\hline
\end{tabular}

$\overline{\mathrm{AF}}=$ atrial fibrillation; $\mathrm{BMI}=$ body mass index; $\mathrm{CTI}=$ cavotricuspid isthmus.

compared to noncontact ECI using a 2-tailed Wilcoxon test. To establish a baseline noncontact ECI value, the first 3 noncontact ECI data points for each patient were averaged, and the offsets from this baseline were calculated for the remaining ECI data points. The sensitivity and specificity of detecting contact were then calculated as the discrimination threshold was varied.

All analysis was performed in the MATLAB environment (Version 7.6.0.324) using the MATLAB Signal Processing Toolbox (Version 6.9) and the MATLAB Statistical Toolbox (Version 6.2) (The Math Works, Natick, MA, USA).

\section{Results}

\section{Patient Population and Procedural Data}

Twelve patients were prospectively studied at the Department of Electrophysiology in the Heart Center of the University of Leipzig, Germany, from July 8, 2008 to July 15, 2008. All patients were undergoing catheter ablation for AF. Table 1 summarizes patient demographics.

Patient histories included hypertension $(\mathrm{N}=4)$, coronary artery disease $(\mathrm{N}=1)$, and a prior cavotricuspid isthmus ablation for atrial flutter $(\mathrm{N}=1)$. Six patients had no history of structural heart disease. Two patients had previously undergone Lasso-guided segmental PV disconnection (patients 2 and 7). The remaining 10 patients had not previously undergone an $\mathrm{AF}$ ablation procedure.

Procedure duration was $135 \pm 41$ minutes, and total fluoroscopy exposure during the procedure was $29 \pm 13 \mathrm{~min}$ utes. Periprocedural complications and adverse events were not observed. In the first patient, data synchronization errors prevented analysis. Thus, 11 of 12 patients were available for analysis.

\section{Local Resistance and Reactance}

Measurements were taken at up to 4 unambiguous noncontact and up to 4 unambiguous contact locations per patient and 5-second averaged values of measurements were calculated. As the catheter went from a noncontact location to a contact location, $\mathrm{R}$ increased from $94.7 \pm 11.0$ to $109.3 \pm$ $15.1 \Omega(\mathrm{P}<0.0001)$, X decreased from $-4.6 \pm 0.9$ to $-6.9 \pm$ $2 \Omega(\mathrm{P}<0.0001)$, and ECI increased from $118 \pm 15$ to $145 \pm$ 24 ( $\mathrm{P}<0.0001)$. For comparison, electrogram amplitudes increased from $0.14 \pm 0.16$ to $2.0 \pm 1.9 \mathrm{mV}(\mathrm{P}<0.0001)$, and pacing thresholds decreased from $13.9 \pm 3.1$ to $3.1 \pm 2.9$ $\mathrm{mA}(\mathrm{P}<0.0001)$ from noncontact to contact locations.

Figure $2 \mathrm{C}$ shows an example of ECI changes during manipulation of the catheter from noncontact to contact. Of note in this example, ECI is not affected by pacing through the tip of the ablation catheter (red arrows). Figure 3 demonstrates the changes in the components of the ECI measure-the increase of resistance and the decrease of reactance (i.e., increase of capacitance) as the catheter is moved from a noncontact to a contact position.

\section{ECI, Electrograms, and Pacing Under Different Levels of Contact}

For further evaluation, clinician-assessed contact levels ("none," "light," "moderate," or "firm") in a minimum of 6
Figure 3. Example showing change in resistance and reactance as the catheter is moved from a noncontact position to a position in contact with the atrial endocardium.

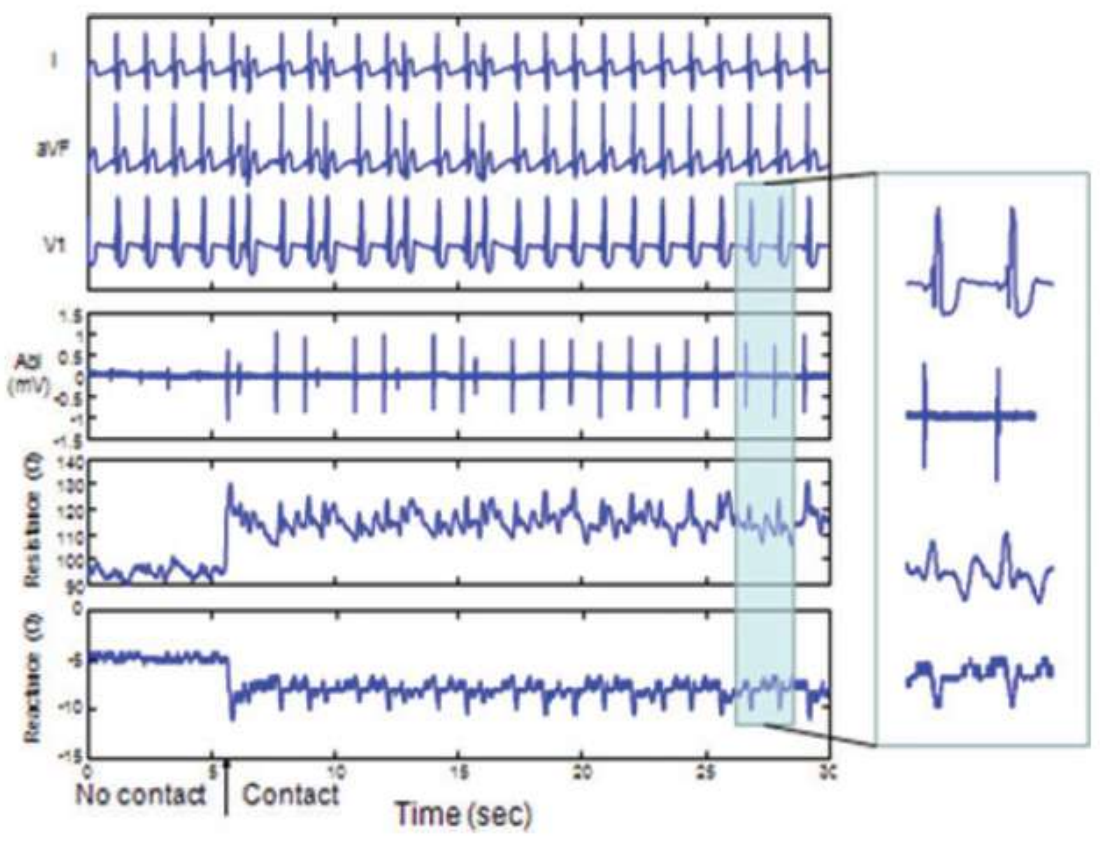


Figure 4. Catheter location for the 3 outliers showing large values of ECI during no contact. In all 3 instances, the catheter was inside a pulmonary vein. For the remaining data segments during no contact, the catheter was not inside a pulmonary vein.
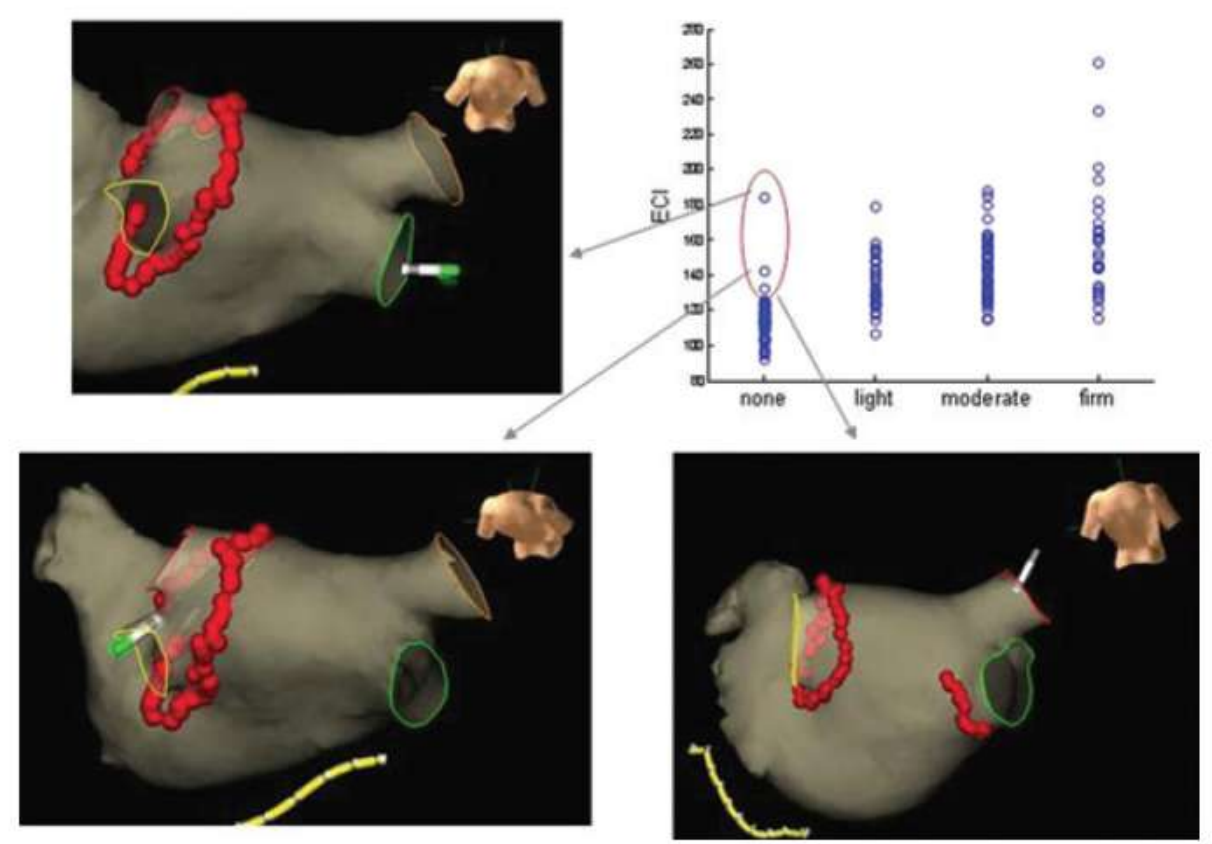

different locations within the left atrium were obtained. Similarly to the binary analysis, $\mathrm{R}$ increased, $\mathrm{X}$ decreased, and ECI increased as contact increased from "none" to "light," "moderate," or "firm" $(\mathrm{P}<0.0001)$. For all patients, the 5-second averages of ECI were $115 \pm 12$ over all no-contact data segments $(\mathrm{n}=69), 135 \pm 15(\mathrm{n}=33)$ for "light" contact, $144 \pm 17(\mathrm{n}=46)$ for "moderate" contact, and $159 \pm 34$ $(\mathrm{n}=26)$ for "firm" contact. Pairwise comparisons, however, were not significantly different between "light," "moderate," and "firm" contact in R, X, or ECI.

To account for the subjectivity of the physician-assessed contact level and the difficulty to distinguish between light and moderate contact, both were combined into a single contact level and determined to be $140.6 \pm 16.9(n=79)$.

When the catheter was placed in a noncontact location, ECI generally varied from 91 to 125 units. In 3 instances, ECI during no contact exceeded this range. Upon closer examination, those ECI outliers occurred when the catheter was well within a pulmonary vein (Fig. 4). For the remaining noncontact positions, the ablation catheter was not inside a pulmonary vein.

\section{Patient-Specific Analysis of ECI}

On a patient-by-patient analysis, absolute values and changes of ECI were analyzed in true contact and true noncontact locations (Fig. 5). Wilcoxon tests showed a significant difference for each patient between true noncontact and true contact (Fig. 5). Patients had an average difference of $32.7 \pm 11.6 \mathrm{ECI}$ units between contact and noncontact values with a $95 \%$ confidence interval of 25.8-39.6. Based on plots of sensitivity and specificity derived from ROC analysis, a discrimination threshold of 5 ECI units above noncontact baseline was chosen to discriminate noncontact from contact ECI data. At this threshold, sensitivity for detecting contact was $97 \%$ and specificity was $95 \%$ (Fig. 5).

\section{Effect of Tissue Type on ECI}

In a subset of data, the catheter was positioned on trabeculated, smooth, or vascular tissue at different levels of contact. Tissue type significantly influenced ECI levels $(\mathrm{P}<0.01)$. ECI in vascular tissue $(153.7 \pm 15.7, \mathrm{n}=20)$ was significantly higher than in trabeculated $(134.9 \pm 13.8, \mathrm{n}=13)$ or smooth tissue $(145.1 \pm 19.5, \mathrm{n}=34)$ but was not statistically different between trabeculated and smooth tissue.

\section{Effect of Patch Orientation, Operator, Body Mass Index (BMI), AF Type on ECI}

$\mathrm{N}$-way ANOVA analysis determined if the patch electrode configuration, catheter operator, patient BMI, or clinical type of AF (paroxysmal or persistent) influenced ECI. Two different patch electrode configurations (leg-neck, $\mathrm{N}=5$ vs front-back, $\mathrm{N}=6$ ) were tested. BMI was $26.8 \pm 2.2$. Nine of 11 patients had paroxysmal AF, and 2 patients had persistent AF. Three experienced operators performed the catheter manipulations for this study.

$\mathrm{N}$-way ANOVA analysis revealed no significant effect on ECI by patch orientation, operator, BMI, or type of AF.

\section{Stability of the Measurement}

To determine ECI measurement stability, ECI was measured in unambiguous contact and noncontact positions at the beginning and end of each study. Procedure durations were $135 \pm 41$ minutes. Using paired, 2-tailed $t$-tests, ECI was found to decrease slightly, from the beginning to the end of the study in both the noncontact position $(115.3 \pm 6.1$ to $106 \pm 7.9, \mathrm{P}<0.001)$ and in the contact position $(142.4 \pm$ 14.5 to $127.3 \pm 14.7, \mathrm{P}<0.01)$.

\section{Discussion}

\section{Main Findings}

While the correlation of adequate contact to lesion size has long been recognized, tools to objectively assess 
Figure 5. Patient-by-patient analysis of noncontact/contact ECI changes, ROC analysis, and cut-off sensitivity/specificity. (A) For each study, patient mean and standard deviation of $E C I$ values in true noncontact and true contact locations are shown. Number of data points in each noncontact/contact location and result of the 2-tailed Wilcoxon test are given for each patient. The red dotted line illustrates the noncontact/contact cut-off value of $5 \mathrm{ECl}$ units above baseline, resulting from the ROC analysis. (B) Plots of sensitivity and specificity of ECI change to discriminate true noncontact from true contact on the patient-by-patient analysis. (C) Data point distribution and calculation of sensitivity and specificity over all acquired true noncontact/contact data points with a noncontact/contact cut-off value of $5 \mathrm{ECl}$ units above baseline.
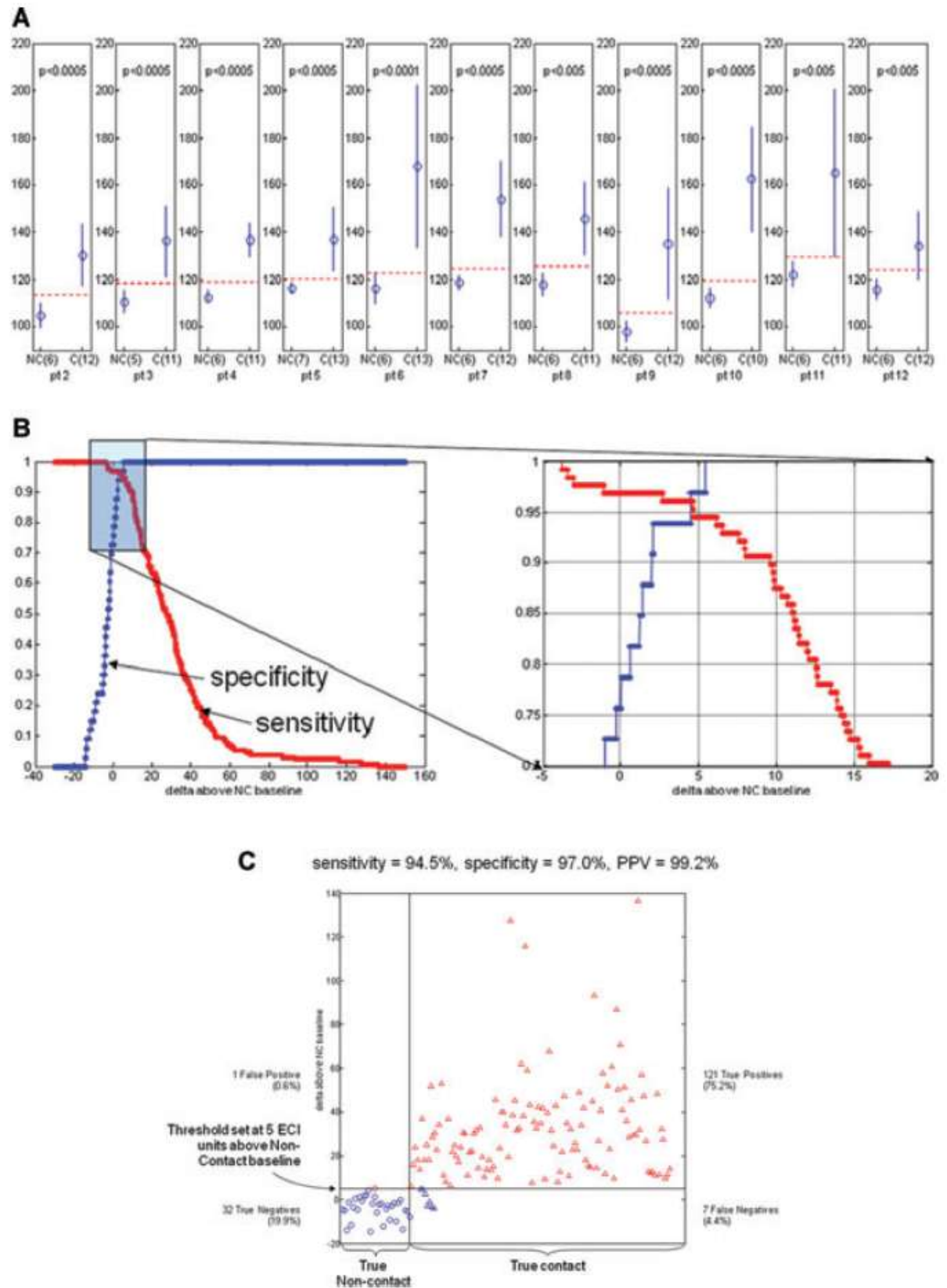

contact have not been available until recently. ${ }^{8-10}$ In this study, ECI was introduced as a novel method for monitoring the electrical coupling between the ablation catheter tip and the endocardial surface in vivo within the human left atrium.

\section{Role of Impedance-Based Measurement of Catheter Contact}

Contact force is known to influence lesion size for nonirrigated and irrigated catheters. ${ }^{10,11}$ However, the principle of contact assessment using specialized force sensors carries 2 distinct limitations. First, force may be an inadequate surrogate for quality and quantity of RF lesion formation in different types of myocardial architecture (trabeculated vs smooth myocardium) and in different types of catheter tipto-surface alignment (perpendicular vs parallel orientation).
Second, a wider use of specialized force sensors would require new catheter technologies and is not applicable through currently available ablation catheters.

On the contrary, the analysis of the electrical properties of the catheter tip-to-surface interface may provide a more precise prediction of the transfer of RF energy from the ablation electrode into the myocardial tissue. This concept has too been shown to correlate to lesion dimensions in preclinical studies. $^{3}$

The clinical need for information on the electrical coupling of the ablation catheter is supported by Schwartzman and coworkers, who reported difficulties in ablating trabeculated myocardium versus smooth myocardium guided by mechanical contact only. ${ }^{11}$

Further discrepancies between lesion dimensions and mechanical contact may be found in situations where ablation is 
being performed within a vessel (such as pulmonary vein or coronary sinus) and contact force measurements may underestimate the amount of RF energy that is delivered into the tissue, while the increased ECI values may provide a more realistic measure of the ablation effect.

Comparative data are needed to confirm these theoretical advantages of ECI over mechanical contact force assessment.

\section{Technical Aspects of Impedance Measurements}

Ablation generators report a 2-terminal magnitude of the impedance. A limitation of generator-reported impedance is that it reflects not only the tip electrode and its environment (signal), but also the ablation dispersive return electrode and thoracic interference (noise).

Alternately, ECI is a composite of the catheter tip-totissue resistance and reactance enabled by the 3-terminal impedance measurement. While monitoring of the ablation impedance during clinical cases is not a new concept, the ability to measure local impedance components specifically between the catheter tip and tissue is novel. ${ }^{12,13}$ This is done at a lower frequency, $20 \mathrm{kHz}$, where reactive changes contribute independent information over just resistance or impedance magnitude.

The theory behind the impact of local impedance has been reported. ${ }^{14}$ Theoretically, the ECI, which is a local electrode tip-to-tissue impedance measure, is robust and is not affected by far-field sensing of impedance changes distant to the electrode. The local measure of impedance allows for elimination of artifact, as well providing the potential of increased ability to detect a local ablation effect. For these same reasons, the electrical coupling between the electrode tip and the myocardium is independent of tip orientation. The ECI is dependent only on the amount of the tip electrode that is in contact with the tissue.

\section{Areas of Potential Clinical Use}

The need for objective contact assessment during RF catheter ablation has been discussed beforehand. Applicable technologies to make this assessment are currently lacking in clinical routine. For this reason, impedance-based catheter contact assessment was used in the human left atrium for the first time in this study. On a blinded evaluation, it was able to robustly and reproducibly describe tissue contact as compared to conventional contact criteria, such as tactile feedback, fluoroscopy, and electrogram amplitude. Larger clinical trials are needed in order to measure the benefit of adding this technology in clinical routine with respect to clinical and procedural outcome measures.

In addition to providing contact information, the assessment of electrical catheter coupling may provide information with respect to lesion formation and differentiation between viable myocardium and scar. Others have reported a correlation between impedance and tissue heating, ${ }^{15}$ as well as the clinical practice of monitoring a decrease in impedance during RF energy delivery. ${ }^{15-17}$ This may make ECI interesting not only as an indicator of catheter tip-tissue contact but also in its potential ability to provide information on effect and outcome of RF lesion formation. Future preclinical and clinical research therefore needs to study ECI behavior in those circumstances.

\section{Limitations}

The main limitation of this study is the definition of the gold standard for "true contact." Clinician-assessed contact, pacing threshold, and electrogram amplitudes were available; however, none of these parameters is necessarily equivalent to "true contact." Additionally, the graded contact analysis is limited by the difficulty to precisely distinguish between "light" and "moderate" contact levels. We, therefore, have added an analysis consolidating both contact levels into a single measure.

In our study, ECI was averaged over a 5-second period. Therefore, it was not intended to display short instantaneous changes in electrical contact (e.g., cardiac cycle related).

As shown in the ANOVA analysis and in the outliers, during the no-contact segments ECI appears to be higher in vascular tissue than in the atria. This is not necessarily a shortcoming of the methodology, as electrical coupling and delivery of RF energy may also be enhanced in these areas. However, comparing vascular ECI values with nonvascular ECI values should be made with caution.

In our data, we noted that ECI values showed a small decrease over the course of the procedure in both contact and noncontact locations. The nature of this change is not fully understood, but might be due to changes in total body fluid (administered fluid load during irrigated ablation). In clinical practice, an algorithm to offset these changes during the procedure would be useful.

\section{Conclusions}

Assessment of electrical properties of the catheter tipto-tissue interface, namely the resistance and the reactance, is feasible in quantitatively describing the electrical tissue coupling of the ablation electrode. The information can be displayed as a compound ECI that was able to reliably and reproducibly distinguish between electrical noncontact and contact locations.

Acknowledgments: The authors express their appreciation of the efforts of the following individuals whose contributions made possible this study: Hong Cao (conceptual leadership), D. Curtis Deno, Russ Kuenzi, Shawn McCutcheon (hardware implementation and supporting studies), Jörg Werner, Brian Schmidt, Patti Griese, and Bettina Geissler (clinical study support).

\section{References}

1. Okumura Y, Johnson SB, Bunch TJ, Henz BD, O'Brien CJ, Packer DL: A systematic analysis of in vivo contact forces on virtual catheter tip/tissue surface contact during cardiac mapping and intervention. J Cardiovasc Electrophysiol 2008;19:632-640.

2. Yokoyama K, Nakagawa H, Shah DC, Lambert H, Leo G, Aeby N, Ikeda A, Pitha JV, Sharma T, Lazzara R, Jackman WM: Novel contact force sensor incorporated in irrigated radiofrequency catheter predicts lesion size and incidence of steam pop and thrombus. Circ Arrhythmia Electrophysiol 2008:1:354-362.

3. Arruda MS, Cao H, Fish JM, Byrd IA, Jensen JA, Puryear HA, Natale A: Novel tissue sensing technology predicts tissue pops and irrigated RF lesion size irrespective of contact force. Heart Rhythm 2008;5(Suppl):S70.

4. Piorkowski C, Kircher S, Arya A, Gaspar T, Esato M, Riahi S, Bollmann A, Husser D, Staab C, Sommer P, Hindricks G: Computed tomography model-based treatment of atrial fibrillation and atrial macro-re-entrant tachycardia. Europace 2008;10:939-948.

5. Oral H, Scharf C, Chugh A, Hall B, Cheung P, Good E, Veerareddy S, Pelosi F Jr, Morady F: Catheter ablation for paroxysmal atrial fibrillation: Segmental pulmonary vein ostial ablation versus left atrial ablation. Circulation 2003;108:2355-2360. 
6. Kottkamp H, Tanner H, Kobza R, Schirdewahn P, Dorszewski A, Gerds-Li JH, Carbucicchio C, Piorkowski C. Hindricks G: Time courses and quantitative analysis of atrial fibrillation episode number and duration after circular plus linear left atrial lesions: Trigger elimination or substrate modification, early or delayed cure? J Am Coll Cardiol 2004; $44: 869-877$

7. Piorkowski C, Kottkamp H, Gerds-Li J-H, Arya A, Sommer P, Dagres N, Esato M, Riahi S, Weiss S, Kircher S, Hindricks G: Steerable sheath catheter navigation for ablation of atrial fibrillation: A case-control study. Pacing Clin Electrophysiol 2008;31:863-873

8. Kalman JM, Fitzpatrick AP, Olgin JE, Chin MC, Lee RJ, Scheinman MM, Lesh MD: Biophysical characteristics of radiofrequency lesion formation in vivo: Dynamics of catheter tip-tissue contact evaluated by intracardiac echocardiography. Am Heart J 1997:133:8-18.

9. Haines DE: Determinants of lesion size during radiofrequency catheter ablation: The role of electrode-tissue contact pressure and duration of energy delivery. J Cardiovasc Electrophysiol 1991;2:509515.

10. Weiss C, Antz M, Eick O, Eshagzaiy K, Meinertz T, Willems S: Radiofrequency catheter ablation using cooled electrodes: Impact of irrigation flow rate and catheter contact pressure on lesion dimensions. Pacing Clin Electrophysiol 2002;25:463-469.

11. Schwartzman D, Michele JJ, Trankiem CT, Ren JF: Electrogramguided radiofrequency catheter ablation of atrial tissue comparison with thermometry-guide ablation. J Interv Card Electrophysiol 2001;5:253266.

12. Harvey M, Kim YN, Sousa J, el-Atassi R, Morady F, Calkins H, Langberg JJ: Impedance monitoring during radiofrequency catheter ablation in humans. Pacing Clin Electrophysiol 1992;15:22-27.

13. Ko WC, Huang SK, Lin JL, Shau WY, Lai LP, Chen PH: New method for predicting efficiency of heating by measuring bioimpedance during radiofrequency catheter ablation in humans. J Cardiovasc Electrophysiol 2001;12:819-823

14. Wittkampf FH, Nakagawa H: RF catheter ablation: Lessons on lesions. Pacing Clin Electrophysiol 2006:29:1285-1297.

15. Reithmann C, Remp T, Hoffmann E, Matis T, Wakili R, Steinbeck $\mathrm{G}$ : Different patterns of the fall of impedance as the result of heating during ostial pulmonary vein ablation: Implications for power titration. Pacing Clin Electrophysiol 2005;28:1282-1291.

16. Nsah E, Berger R, Rosenthal L, Hui R, Ramza B, Jumrussirikul P, Lawrence JH, Tomaselli G, Kass D, Calkins H: Relation between impedance and electrode temperature during radiofrequency catheter ablation of accessory pathways and atrioventricular nodal re-entrant tachycardia. Am Heart J 1998;136:844-851.

17. Thiagalingam A, D'Avila A, McPherson C, Malchano Z, Ruskin J, Reddy VY: Impedance and temperature monitoring improve the safety of closed-loop irrigated-tip radiofrequency ablation. J Cardiovasc Electrophysiol 2007; 18:318-325 


\subsection{Risiken der katheterinterventionellen Therapie von Vorhofflimmern}

\subsubsection{Komplikationen der Vorhofflimmerablation in einer großen klinischen Patientenkohorte}

Zitierweise:

Nikolaos Dagres, M.D., Gerhard Hindricks, M.D., Ph.D., Hans Kottkamp, M.D., Ph.D., Philipp Sommer, M.D., Thomas Gaspar, M.D., Kerstin Bode, M.D., Arash Arya, M.D., Daniela Husser, M.D., Loukianos S. Rallidis, M.D., Dimitrios Th. Kremastinos, M.D., and Christopher Piorkowski, M.D.

Complications of Atrial Fibrillation Ablation in a High-Volume Center in 1,000 Procedures: Still Cause for Concern?

J Cardiovasc Electrophysiol, 2009 May 20, Vol. pp. 1-6, [Epub ahead of print]. 


\title{
Complications of Atrial Fibrillation Ablation in a High-Volume Center in 1,000 Procedures: Still Cause for Concern?
}

\author{
NIKOLAOS DAGRES, M.D., ${ }^{*}$ GERHARD HINDRICKS, M.D., PH.D., $\dagger$ \\ HANS KOTTKAMP, M.D., PH.D., $\ddagger$ PHILIPP SOMMER, M.D. $\dagger \dagger$ THOMAS GASPAR, M.D.,$\dagger$ \\ KERSTIN BODE, M.D.,$\dagger$ ARASH ARYA, M.D.,$\dagger$ DANIELA HUSSER, M.D.,$\dagger$ \\ LOUKIANOS S. RALLIDIS, M.D., ${ }^{*}$ DIMITRIOS TH. KREMASTINOS, M.D., \\ and CHRISTOPHER PIORKOWSKI, M.D. $\dagger$
}

From the *Second Cardiology Department, University of Athens, Attikon University Hospital, Athens, Greece; †Department of Electrophysiology, University of Leipzig, Heart Center, Leipzig, Germany; and †̦Department of Electrophysiology, Heart Center Hirslanden, Zurich, Switzerland

Complications of Atrial Fibrillation Ablation. Introduction: Catheter ablation is potentially curative treatment for atrial fibrillation (AF). However, complications are more frequent and more severe compared with other ablation procedures. We investigated the complication rate in 1,000 AF ablation procedures in a high-volume center and examined possible risk factors.

Methods and Results: One thousand consecutive circumferential pulmonary vein radiofrequency ablations were performed for symptomatic, drug-refractory AF. Major complications were defined as the ones that were life threatening, caused permanent harm, and required intervention or prolonged hospitalization. Thirty-nine $(3.9 \%)$ major periprocedural complications were observed. There was no death immediately associated with the procedure. However, there were 2 deaths $(0.2 \%)$ of unclear cause, 14 days and 4 weeks after ablation. The most common complications were tamponade $(1.3 \%)$, treated mainly by percutaneous drainage, and vascular complications $(1.1 \%)$. There were also 4 thromboembolic events $(0.4 \%)$ : 3 nonfatal strokes and one transient ischemic attack. Importantly, 2 cases $(0.2 \%)$ of atrial-esophageal fistula and 2 cases $(0.2 \%)$ of endocarditis were observed. Factors associated with an increased complication risk were age $\geq 75$ years (hazard ratio $3.977, P=0.022$ ) and congestive heart failure (hazard ratio 5.174 , $\mathrm{P}=0.001)$.

Conclusion: AF ablation still has a considerable number of major complications that may be life threatening or may lead to severe residues. Atrial-esophageal fistula is still observed despite continuous systematic methods to prevent it. Stroke, tamponade, and vascular complications are the most frequent major complications. However, in most patients treatment can be conservative and results in complete recovery. Advanced age and congestive heart failure seem to be associated with an increased risk of complications. (J Cardiovasc Electrophysiol, Vol. pp. 1-6)

catheter ablation, atrial fibrillation, complications, atrial-esophageal fistula, sudden death

\section{Introduction}

Radiofrequency catheter ablation is a breakthrough in the management of atrial fibrillation (AF), offering potentially curative treatment. However, complications of the technique are more frequent and more severe compared with other ablation procedures. Reports on this topic are inconsistent. High-volume centers reported very low complication rates, ${ }^{1,2}$ whereas a worldwide survey performed in the first years of $\mathrm{AF}$ ablation therapy reported a major complication rate of $6 \% .^{3}$ More recent reports from a multicenter registry and from an experienced center yielded lower but still considerable complication rates of $3.9 \%$ and $5 \%$, respectively. ${ }^{4,5}$

Address for correspondence: Nikolaos Dagres, M.D., Second University Cardiology Department, Attikon University Hospital, Rimini 1, Haidari, 12462 Athens, Greece. Fax: +30-210-583-2351; E-mail: nikolaosdagres@ yahoo.de

Manuscript received 31 December 2008; Revised manuscript received 19 March 2009; Accepted for publication 24 March 2009.

doi: $10.1111 / \mathrm{j} .1540-8167.2009 .01493 . \mathrm{x}$
Controversial are also the data on possible risk factors for complications. Advanced age and female gender predicted complications in one report, ${ }^{5}$ but this finding was not confirmed by others. $4,6,7$

The aim of the present study was to prospectively investigate the complication rate of $\mathrm{AF}$ ablation in a single high-volume center in 1,000 consecutive procedures and to examine possible risk factors for complications in this large patient cohort.

Methods

\section{Study Population}

A total of 1,000 consecutive ablation procedures for AF were performed at the Department of Electrophysiology of the Heart Center Leipzig in Germany from October 2005 until January 2008. An indication for ablation was symptomatic, paroxysmal, persistent, or permanent $\mathrm{AF}$, refractory to at least one antiarrhythmic drug. Patient characteristics are given in Table 1. Before ablation, patients underwent multislice cardiac CT of the heart for the reconstruction of the left atrium (LA), pulmonary veins, and esophagus. 
TABLE 1

Patient Characteristics

\section{Age (years)}

Male gender $(\%)$

Duration of AF (median in months)

Type of AF

Paroxysmal (\%)

Persistent (\%)

Permanent $(\%)$

Arterial hypertension (\%)

Coronary artery disease $(\%)$

Congestive heart failure $(\%)$

Diabetes (\%)

Left ventricular ejection fraction $(\%)$

Left atrial diameter $(\mathrm{cm})$

$58 \pm 10$

68

48

51

13

52

\section{Ablation Procedure}

Ablation procedures were performed after written informed consent was obtained from all patients, as previously described. ${ }^{8.9}$ The same uniform protocol was strictly applied for all procedures by a total of 5 experienced operators. The procedures were performed in deep sedation/analgesia with administration of propofol and fentanyl with preservation of spontaneous breathing and continuous monitoring of systemic arterial pressure and oxygen saturation.

Three venous sheaths $(5,6$, and 12 French $)$ and one arterial sheath (4 French) were placed in the femoral veins/arteries. Four and 6 French catheters were introduced into the right ventricle and the coronary sinus, respectively. A single transseptal puncture was performed and an 8.5 French steerable introducer (Agilis NxT, St. Jude Medical) was advanced into the LA. For the rest of the procedure, the introducer was irrigated with a heparinized saline solution. Ablation was performed with a 3.5- or 4-mm irrigated tip catheter (Navistar Thermocool, Johnson \& Johnson, or Therapy Cool Path, St. Jude Medical). Radiofrequency current was used as energy source in a temperature-guided fashion with preselected temperature of $48^{\circ} \mathrm{C}$ and maximum power of $40 \mathrm{~W}$.

In all patients, circular linear lesions were placed in the LA around the ostia of the pulmonary veins (PVs) with use of an electromagnetic mapping system (CARTO, Biosense Webster, or NavX, Endocardial Solutions). The transition from the PVs into the LA was determined by combining information from fluoroscopy, impedance changes, and electrogram characteristics. ${ }^{9}$ In patients with persistent AF, additional linear lesion lines were deployed between the circular lesions along the LA roof and along the mitral isthmus. Voltage mapping and pacing maneuvers were performed inside the encircled areas and the PVs to test for remaining PV conduction or complete PV isolation with bidirectional block. ${ }^{9}$ Autonomic ganglionated plexi ablation was not deliberately attempted.

To prevent esophageal damage, topographic tagging of the esophageal position with the electroanatomical mapping system was routinely performed in order to avoid energy application in close vicinity to the esophagus. ${ }^{10}$ In areas adjacent to the esophagus, radiofrequency generator power was reduced to $25 \mathrm{~W},{ }^{9}$ and the ablation catheter was moved every $10-15$ seconds. In addition, since April 2007 we have used a special temperature probe (Esotherm, FIAB SpA) that was introduced into the esophagus for continuous monitoring of the luminal temperature of the esophagus during the procedure. In case of a rise of the luminal temperature $>41^{\circ} \mathrm{C}$, energy application was stopped immediately and restarted later with reduced power after the normalization of the temperature. The probe was first used sporadically up to the second case of atrial-esophageal fistula and routinely thereafter.

The mean procedure time was $159 \pm 39$ minutes, fluoroscopy time $24 \pm 11$ minutes, and radiofrequency application time $48 \pm 19$ minutes.

\section{Anticoagulation}

Patients underwent transesophageal echocardiography prior to the procedure in order to exclude the presence of thrombus in the LA. During the procedure, anticoagulation was achieved with unfractionated heparin with administration of a first loading dose of $100 \mathrm{U} / \mathrm{kg}$ directly after the successful transseptal puncture. Activated clotting time (ACT) was measured initially every $10-15$ minutes and then at 30 minute intervals, and the heparin dose was adjusted in order to maintain a target ACT of 300 seconds. After the procedure, patients received low-molecular-weight heparin in therapeutic dose (enoxaparin $1 \mathrm{mg} / \mathrm{kg}$ body weight twice daily) with simultaneous initiation of oral anticoagulation therapy. After achievement of the target international normalized ratio (INR), low-molecular-weight heparin was discontinued.

In the absence of complications, patients were typically discharged 2 days after the procedure and after a total hospital stay of 3 days.

\section{Definition of Complications}

Data on complications were collected prospectively. We defined as major complications the ones that were life threatening, caused permanent harm, required intervention, or prolonged hospitalization. We focused on periprocedural complications, defined as those occurring within 1 month after the procedure. This definition was not applied for the atrialesophageal fistula and the PV stenosis due to their delayed occurrence.

\section{Follow-Up}

A strict follow-up program was applied with serial 7-day Holter ECGs directly after the procedure and at 3,6, and 12 months, as previously reported. ${ }^{8}$ In the case of nonappearance at the follow-up dates, patients were contacted by telephone by the secretariat for AF ablation.

\section{Statistical Analysis}

Categorical variables are presented as numbers and percentages of patients and continuous variables as mean \pm SD. To evaluate differences between groups, the chi-square test was used for categorical variables and the $t$-test or the MannWhitney $U$-test for continuous variables as appropriate. Cox regression was applied for calculation of the hazard ratios for variables associated with higher complication risk. Analyses were performed with the software package SPSS version 11.5 (SPSS Inc., Chicago, IL, USA). A P value $<0.05$ was considered significant.

\section{Results}

A total of 39 (3.9\%) major complications were observed, as shown in Table 2. 
TABLE 2

Major Complications

\begin{tabular}{lr}
\hline & $\begin{array}{r}\mathrm{n}=\mathbf{1 . 0 0 0} \\
\text { procedures }\end{array}$ \\
\hline Death immediately associated with the procedure & 0 \\
Death of unclear cause & $2(0.2 \%)$ \\
Atrial-esophageal fistula & $2(0.2 \%)$ \\
Thromboembolic complications & $4(0.4 \%)$ \\
Stroke & $3(0.3 \%)$ \\
Transient ischemic attack & $1(0.1 \%)$ \\
Tamponade & $13(1.3 \%)$ \\
Percutaneous drainage & $11(1.1 \%)$ \\
Surgically treated & $2(0.2 \%)$ \\
Severe pulmonary vein stenosis & $1(0.1 \%)$ \\
Endocarditis & $2(0.2 \%)$ \\
Retroperitoneal hematoma & $1(0.1 \%)$ \\
Deep vein thrombosis & $1(0.1 \%)$ \\
Aspiration with or without pneumonia & $2(0.2 \%)$ \\
Femoral pseudoaneurysm & $9(0.9 \%)$ \\
Conservatively treated & $4(0.4 \%)$ \\
Treated with thrombin injection & $3(0.3 \%)$ \\
Surgically treated* & $2(0.2 \%)$ \\
Arteriovenous fistula & $3(0.3 \%)$ \\
Conservatively treated & $2(0.2 \%)$ \\
Surgically treated* & $1(0.1 \%)$ \\
Total & $39(3.9 \%)$ \\
\hline
\end{tabular}

*In one case, both a femoral pseudoaneurysm and an arteriovenous fistula were observed after the procedure and were treated surgically. These are counted as one complication.

\section{Deaths}

There was no death immediately associated with the procedure. However, there were 2 deaths of unclear cause in the postprocedural period. The first one was a sudden death 14 days after ablation of a patient with arterial hypertension, without structural heart disease, and with normal left ventricular systolic function. After ablation, this patient developed a femoral pseudoaneurysm and an arteriovenous fistula, which were surgically corrected 5 days after the procedure. From this time point, the patient was completely asymptomatic and felt very well up to the 14th postablation day, when she died suddenly. The second case occurred 4 weeks after ablation of a patient with dilated cardiomyopathy and severely impaired left ventricular systolic function. This patient developed symptoms compatible with atrial-esophageal fistula: neurological symptoms (incomplete hemiparesis and seizures) and sepsis. The procedure was performed without use of the esophageal temperature probe. Since no autopsy was performed, the cause of death remains unknown. In both cases, there was no evidence of ganglionated plexi ablation. A 7-day Holter ECG was performed directly after the procedure and showed in both patients no signs of parasympathetic denervation, such as elevated heart rate or decreased heart rate variability.

\section{Atrial-Esophageal Fistula}

Two cases $(0.2 \%)$ of atrial-esophageal fistula were observed. Patients became symptomatic 4 and 23 days after ablation, respectively, with typical symptoms: fever in the first case and thoracic pain in the second. Both underwent surgical resection of the esophagus, which confirmed the diagnosis. The first patient had a complicated course and survived with severe neurological residues, whereas the sec- ond patient did not develop neurological symptoms and had a protracted course but without significant residues. In one of these 2 patients, a previous AF ablation procedure had been performed 8 weeks earlier and the patient underwent a second procedure due to LA flutter with rapid ventricular conduction. In both cases, procedures were performed without use of the esophageal temperature probe. The position of the esophagus in relation to the LA was classified according to the method proposed by Kottkamp et al. ${ }^{10}$ In both patients the esophagus had contact with the mid- to inferior portion of the posterior LA wall, medially in one of them (column C), and toward the left PVs in the other (column B).

No case of documented or suspected atrial-esophageal fistula was observed after procedures in which the esophageal temperature probe was used $(n=193)$.

\section{Thromboembolic Complications}

Three nonfatal strokes $(0.3 \%)$ and one transient ischemic attack $(0.1 \%)$ occurred up to the eighth postablation day. One of the strokes was treated with thrombolysis. Three of these 4 thromboembolic complications occurred within the first 24 hours after ablation. The fourth case occurred on the eighth postablation day. This patient was discharged with enoxaparin in a dosage of $90 \mathrm{mg}$ once daily (at a body weight of $98 \mathrm{~kg}$ ) and initiation of oral anticoagulation. At the time of the event, the patient was still receiving a combination of oral anticoagulation and enoxaparin. The INR was 1.2.

\section{Tamponade}

There were 13 cases $(1.3 \%)$ of tamponade developing shortly after the procedure and requiring immediate drainage. Two of these patients had to be resuscitated due to cardiac arrest. Drainage was mainly achieved by percutaneous pericardial puncture $(\mathrm{n}=11)$. Surgical treatment was necessary in two patients. In both these cases, a perforation of the LA caused by the ablation catheter was found and treated in the operating theater: in the first case, at the junction of the LA with the left superior PV and in the second, in close proximity to the coronary sinus. All patients had an uneventful recovery.

\section{Vascular Complications}

Vascular complications were observed in 11 patients $(1.1 \%)$ : 9 femoral pseudoaneurysms and 3 arteriovenous fistulas (in one case, both pseudoaneurysm and fistula were observed). The majority of them could be treated conservatively or with thrombin injection.

\section{Other Major Complications}

There was one $(0.1 \%)$ severe PV stenosis that was treated with percutaneous PV angioplasty. Two cases of endocarditis (with vegetations on the mitral valve and at the left atrial appendage entrance, respectively) were treated conservatively and had a favorable outcome. We observed 2 cases of sedation-associated aspiration leading to pneumonia in one of them. Both patients were treated with intravenous antibiotics and had a favorable course.

\section{Minor Complications}

In 2 patients, the procedure was terminated due to contrast media exit into the pericardium during the transseptal 
TABLE 3

Comparison of Patients With and Without Major Complications

\begin{tabular}{lccc}
\hline & $\begin{array}{c}\text { No } \\
\text { Complication }\end{array}$ & Complication & $\begin{array}{c}\text { P } \\
\text { Value }\end{array}$ \\
\hline Patient characteristics & & & \\
Age (years) & $58 \pm 10$ & $61 \pm 10$ & 0.096 \\
Age $\geq 75$ years (\%) & 2 & 9 & 0.015 \\
Female gender (\%) & 32 & 27 & 0.506 \\
Arterial hypertension (\%) & 52 & 61 & 0.308 \\
Coronary artery disease (\%) & 7 & 12 & 0.224 \\
Congestive heart failure (\%) & 3 & 15 & $<0.001$ \\
Diabetes (\%) & 8 & 3 & 0.317 \\
LA diameter (cm) & $4.2 \pm 0.7$ & $4.3 \pm 0.4$ & 0.581 \\
LV ejection fraction (\%) & $59 \pm 11$ & $59 \pm 14$ & 0.755 \\
Procedural characteristics & & & \\
Procedure duration (minutes) & $159 \pm 39$ & $151 \pm 34$ & 0.321 \\
RF application time (seconds) & $2,861 \pm 1,179$ & $2,685 \pm 878$ & 0.811 \\
Fluoroscopy time (minutes) & $24 \pm 11$ & $22 \pm 7$ & 0.494 \\
\hline
\end{tabular}

$\mathrm{LA}=$ left atrial; $\mathrm{LV}=$ left ventricular.

puncture. Both had an uncomplicated course. In one additional patient, the procedure was terminated due to elevation of $\mathrm{CO}_{2}$ during sedation which did not cause any further problems.

\section{Complication Predictors}

As shown in Table 3, the percentages of patients with advanced age ( $\geq 75$ years) and with congestive heart failure were higher in the group of patients who developed a major complication compared with patients who had no major complication. All other examined parameters, including gender, showed no significant difference between patients with and without major complications. In univariate Cox regression, both age $\geq 75$ and congestive heart failure predicted the occurrence of major complications (age $\geq 75$ : hazard ratio $3.977,95 \%$ CI $1.216-13.010, \mathrm{P}=0.022$; congestive heart failure: hazard ratio $5.174,95 \% \mathrm{CI} 1.998-13.403, \mathrm{P}=0.001$ ).

There was no relationship between the operator and the complication rate; the percentage of major complications ranged for all five operators between 2.1 and $5.4 \%$ with a very experienced operator having the highest complication rate of $5.4 \%(\mathrm{P}=0.309)$.

\section{Rhythm Follow-up}

During 7-day Holter recording at 6 and 12 months, arrhythmia recurrences were detected in $25 \%$ and $31 \%$ of the patients, respectively.

\section{Discussion}

The main finding of the study is that AF ablation still has a considerable complication rate even in experienced high-volume centers and despite the significant progress that has been made in that field. Importantly, a number of these complications may be immediately life threatening or result in severe residues. Advanced age and congestive heart failure seem to be associated with a higher risk of complications.

Although the total rate of adverse events in our series was similar with recent reports, ${ }^{4,5}$ there are some important new observations.
First, the observation of two deaths of unclear cause after the procedure is a concerning finding. Although one of these patients had a dilated cardiomyopathy with severely depressed left ventricular function, the combination of neurological symptoms (incomplete hemiparesis and seizures) and sepsis would be compatible with atrial-esophageal fistula. However, this is speculative, since no autopsy was performed. The other patient had no structural heart disease and we have no reasonable explanation for the event.

We observed 2 cases of documented atrial-esophageal fistula corresponding to a rate of $0.2 \%$. These are cases that have not been reported in our previous publications. ${ }^{11}$ Our team was the first to report this potentially devastating complication, ${ }^{12}$ and our findings show that this complication still occurs despite the high degree of awareness in our center ${ }^{10-12}$ and the significant and constant efforts to avoid it by combined means. Because of the nonspecific symptoms and the delayed occurrence that hinder the diagnosis, it could be postulated that the true rate might be even higher. Both atrialesophageal fistulas were observed after procedures without use of the esophageal temperature probe, whereas we did not notice this complication after the 193 procedures in which the probe was used. However, due to the small number of events, we cannot assess whether the use of the probe exerted a protective effect. In this context, it has been reported that measurement of the luminal temperature may underestimate the esophageal tissue temperature during ablation. ${ }^{13}$

Tamponade was the most frequent major complication in our series. The rate of tamponade was higher than the one reported by Bertaglia et al. ${ }^{4}$ and was very similar with the one reported by Cappato et al. ${ }^{3}$ and Spragg et al. ${ }^{5}$ Even though potentially life threatening, as evidenced by the need for cardiopulmonary resuscitation in 2 of our patients, all cases were successfully treated. In the great majority, percutaneous drainage was sufficient and only in 2 of the 13 cases with tamponade surgical revision was needed.

As previously demonstrated, the power settings influence the procedural outcome, with higher generator power being associated with a higher complication rate, including tamponade, and higher luminal esophageal temperatures, but also with an improved LA instrumentation as well as a reduced fluoroscopy time. ${ }^{14,15}$ Although the temperature limit of $48^{\circ} \mathrm{C}$ in our series might appear relatively high, the generator settings that we applied were in principle concordant with the recommendations of other investigators who suggested the use of a modified approach applying lower power at LA locations with higher complication risk and greater power at the other LA locations. ${ }^{15}$ With this approach, the rate of tamponade in our series was comparable with that in other reports. ${ }^{3,5}$ However, we do not know whether a reduced generator power would lead to a decrease to even lower numbers in the range from $0.1 \%$ to $0.6 \%$, as reported by other investigators. ${ }^{4,16}$ We also do not know whether reduced temperature limit and generator power would be helpful in avoiding esophageal perforation.

We observed only one case of severe PV stenosis $(0.1 \%)$. Although we did not routinely perform CT or MR imaging of the PVs during the follow-up, patients routinely underwent transesophageal echocardiography with assessment of PV flows at 6 months postablation. Interestingly, the technique of circumferential PV ablation significantly reduced the occurrence of this complication by avoiding energy application within the PVs, but did not completely abolish it. 
We did not observe other previously reported rare complications such as air embolism, coronary artery damage, or radiation injury. ${ }^{17-19} \mathrm{We}$ also did not observe cases of acute pyloric spasm and gastric hypomotility following ablation as reported by Shah et al. ${ }^{20}$ Given the strict follow-up program, it is unlikely that we have missed a complication producing such intense symptoms, although we cannot exclude the occurrence of subclinical gastric hypomotility. We do not have a reasonable explanation for this disparity, especially given the fact that our energy settings do not seem to deviate significantly from the ones described in that report. Whether the high location variability of the relevant nerve fibers could offer an explanation is a conjecture.

Except for the lower rate of PV stenosis, the rate of adverse events in our series was in general comparable with that reported in the worldwide survey by Cappato $\mathrm{et} \mathrm{al} .^{3}$ regarding both quantity and quality. It has been hypothesized that the complication rate in that survey could be explained to some degree by the diversity of the applied ablation techniques, the variability of the center experience, as well as the learning curve that is expected with a new method. ${ }^{3,21}$ With rising experience and technical developments in catheter and sheath technology as well as in the software of the electroanatomical mapping equipment, one would anticipate a decline of adverse events. However, this does not seem to be the case, as evidenced by the similar complication rates that were observed not only in our report but also in the recent reports of Bertaglia et al. and Spragg et al. ${ }^{4,5}$ Obviously, AF ablation is a complex technique with a relatively high inherent risk. Factors that could explain this include the demand for extensive manipulations in the LA, the need for transseptal puncture and continuous anticoagulation, possible adverse effects of sedation, etc. However, it has to be noticed that the great majority of these complications could be treated conservatively and did not leave permanent residues resulting in a favorable outcome in the overwhelming majority of the patients.

Factors associated with an increased complication risk in our study were advanced age and congestive heart failure. Advanced age has been also identified as a predictor of complications in other reports, ${ }^{5,22}$ whereas this finding is not confirmed by recent studies that have shown a favorable outcome of AF ablation in the elderly. ${ }^{6,7,23}$ Similarly, several reports have shown a very good outcome of $\mathrm{AF}$ ablation in patients with heart failure. ${ }^{24,25}$ In contrast, we could not confirm the previous finding of a higher risk in female patients. ${ }^{5}$ Obviously, these differences will be clarified by further investigations.

To appraise the cost-benefit relation of the ablation method for treatment of AF, one must take into account both the procedural risk and the long-term outcome. During 7-day Holter recordings at the follow-up, approximately $70 \%$ of the studied patients had no recurrences. This is a remarkable achievement of catheter ablation considering the fact that our study population consisted of patients who had highly symptomatic AF despite antiarrhythmic drug therapy.

In conclusion, AF ablation still has a considerable number of major complications that may be life threatening or may lead to severe residues. Atrial-esophageal fistula is still observed despite continuous systematic methods to prevent it. Stroke, tamponade, and vascular complications are the most frequent major complications. However, in most patients treatment can be conservative and results in complete recovery. Advanced age and congestive heart failure seem to be associated with an increased risk of complications. Approximately $70 \%$ of the patients remain free of arrhythmia recurrences during 7-day Holter recordings at the follow-up.

\section{References}

1. Wazni OM, Marrouche NF, Martin DO, Verma A, Bhargava M, Saliba W, Bash D, Schweikert R, Brachmann J, Gunther J, Gutleben K, Pisano E, Potenza D, Fanelli R, Raviele A, Themistoclakis S, Rossillo A, Bonso A, Natale A: Radiofrequency ablation vs antiarrhythmic drugs as firstline treatment of symptomatic atrial fibrillation: A randomized trial. JAMA 2005;293:2634-2640.

2. Oral H, Pappone C, Chugh A, Good E, Bogun F, Pelosi F Jr, Bates ER, Lehmann MH, Vicedomini G, Augello G, Agricola E, Sala S, Santinelli V, Morady F: Circumferential pulmonary-vein ablation for chronic atrial fibrillation. N Engl J Med 2006;354:934-941.

3. Cappato R, Calkins H, Chen SA, Davies W, Iesaka Y, Kalman J, Kim YH, Klein G, Packer D, Skanes A: Worldwide survey on the methods, efficacy, and safety of catheter ablation for human atrial fibrillation. Circulation 2005:111:1100-1105.

4. Bertaglia E, Zoppo F, Tondo C, Colella A, Mantovan R, Senatore G, Bottoni N, Carreras G, Corò L, Turco P, Mantica M, Stabile G: Early complications of pulmonary vein catheter ablation for atrial fibrillation: A multicenter prospective registry on procedural safety. Heart Rhythm 2007:4:1265-1271

5. Spragg DD, Dalal D, Cheema A, Scherr D, Chilukuri K, Cheng A, Henrikson CA. Marine JE, Berger RD, Dong J, Calkins H: Complications of catheter ablation for atrial fibrillation: Incidence and predictors. J Cardiovasc Electrophysiol 2008;19:627-631.

6. Corrado A, Patel D, Riedlbauchova L, Fahmy TS, Themistoclakis S, Bonso A, Rossillo A, Hao S, Schweikert RA, Cummings JE, Bhargava M, Burkhardt D, Saliba W, Raviele A, Natale A: Efficacy, safety, and outcome of atrial fibrillation ablation in septuagenarians. J Cardiovasc Electrophysiol 2008:19:807-811.

7. Zado E, Callans DJ, Riley M, Hutchinson M, Garcia F, Bala R, Lin D, Cooper J, Verdino R, Russo AM. Dixit S, Gerstenfeld E, Marchlinski FE: Long-term clinical efficacy and risk of catheter ablation for atrial fibrillation in the elderly. J Cardiovasc Electrophysiol 2008;19:621626.

8. Kottkamp H, Tanner H, Kobza R, Schirdewahn P, Dorszewski A, GerdsLi JH, Carbucicchio C, Piorkowski C, Hindricks G: Time courses and quantitative analysis of atrial fibrillation episode number and duration after circular plus linear left atrial lesions: Trigger elimination or substrate modification: Early or delayed cure? J Am Coll Cardiol 2004; $44: 869-877$

9. Piorkowski C, Kottkamp H, Gerds-Li JH, Arya A, Sommer P, Dagres N, Esato M, Riahi S, Weiss S, Kircher S, Hindricks G: Steerable sheath catheter navigation for ablation of atrial fibrillation: A case-control study. Pacing Clin Electrophysiol 2008;31:863-873.

10. Kottkamp H, Piorkowski C, Tanner H, Kobza R. Dorszewski A, Schirdewahn P, Gerds-Li JH, Hindricks G: Topographic variability of the esophageal left atrial relation influencing ablation lines in patients with atrial fibrillation. J Cardiovasc Electrophysiol 2005;16:146-150.

11. Dagres N, Kottkamp H, Piorkowski C, Doll N, Mohr F, Horlitz M, Kremastinos DT, Hindricks G: Rapid detection and successful treatment of esophageal perforation after radiofrequency ablation of atrial fibrillation: Lessons from five cases. J Cardiovasc Electrophysiol 2006; 17:1213-1215.

12. Doll N, Borger MA, Fabricius A, Stephan S, Gummert J, Mohr FW, Hauss J, Kottkamp H, Hindricks G: Esophageal perforation during left atrial radiofrequency ablation: Is the risk too high? J Thorac Cardiovasc Surg 2003; 125:836-842

13. Cummings JE, Barrett CD, Litwak KN, Di Biase L, Chowdhury P, Oh S, Ching CK, Saliba WI, Schweikert RA, Burkhardt JD, De Marco S, Armaganijan L, Natale A: Esophageal luminal temperature measurement underestimates esophageal tissue temperature during radiofrequency ablation within the canine left atrium: Comparison between $8 \mathrm{~mm}$ tip and open irrigation catheters. J Cardiovasc Electrophysiol 2008;19:641644.

14. Hsu LF, Jaïs P, Hocini M, Sanders P, Scavée C, Sacher F, Takahashi Y, Rotter M, Pasquie JL, Clémenty J, Haïssaguerre M: Incidence and prevention of cardiac tamponade complicating ablation for atrial fibrillation. Pacing Clin Electrophysiol 2005;28(Suppl 1):S106-S109.

15. Kanj MH, Wazni O, Fahmy T, Thal S, Patel D, Elay C, Di Biase L, Arruda M, Saliba W, Schweikert RA, Cummings JE, Burkhardt 
JD, Martin DO, Pelargonio G, Dello Russo A, Casella M, Santarelli P, Potenza D, Fanelli R, Massaro R, Forleo G, Natale A: Pulmonary vein antral isolation using an open irrigation ablation catheter for the treatment of atrial fibrillation: A randomized pilot study. J Am Coll Cardiol 2007;49:1634-1641.

16. Pappone C, Santinelli V: Atrial fibrillation ablation: State of the art, Am J Cardiol 2005:96:59L-64L

17. Takahashi Y, Jaïs P, Hocini M, Sanders P, Rotter M, Rostock T, Sacher F, Jaïs C, Clémenty J, Haïssaguerre M: Acute occlusion of the left circumflex coronary artery during mitral isthmus linear ablation. J Cardiovase Electrophysiol 2005;16:1104-1107.

18. Mofrad P, Choucair W, Hulme P, Moore H: Case report: Cerebral air embolization in the electrophysiology laboratory during transseptal catheterization: Curative treatment of acute left hemiparesis with prompt hyperbaric oxygen therapy. J Interv Card Electrophysiol 2006; 16:105-109.

19. Kim HS, Lee JY, Park HJ, Cho BK: Two cases of radiation-induced skin injuries occurring after radiofrequency catheter ablation therapy for atrial fibrillation. J Am Acad Dermatol 2005;53:1083-1084.
20. Shah D, Dumonceau JM, Burri H, Sunthorn H, Schroft A, Gentil-Baron P, Yokoyama Y, Takahashi A: Acute pyloric spasm and gastric hypomotility: An extracardiac adverse effect of percutaneous radiofrequency ablation for atrial fibrillation. J Am Coll Cardiol 2005;46:327-330.

21. Hutchinson M, Callans DJ: Assessing the complications from atrial fibrillation ablation: Closer to truth. Heart Rhythm 2007;4:1272-1273.

22. Oral H, Morady F: How to select patients for atrial fibrillation ablation. Heart Rhythm 2006;3:615-618.

23. Nademanee K, Schwab MC, Kosar EM, Karwecki M, Moran MD, Visessook N, Michael AD, Ngarmukos T: Clinical outcomes of catheter substrate ablation for high-risk patients with atrial fibrillation. J Am Coll Cardiol 2008;51:843-849.

24. Hsu LF, Jaïs P, Sanders P, Garrigue S, Hocini M, Sacher F, Takahashi Y, Rotter M, Pasquié JL, Scavée C, Bordachar P, Clémenty J, Haïssaguerre M: Catheter ablation for atrial fibrillation in congestive heart failure. $\mathrm{N}$ Engl J Med 2004;351:2373-2383.

25. Gentlesk PJ, Sauer WH, Gerstenfeld EP, Lin D, Dixit S, Zado E, Callans D, Marchlinski FE: Reversal of left ventricular dysfunction following ablation of atrial fibrillation. J Cardiovasc Electrophysiol 2007:18:9-14. 


\subsection{Risiken der katheterinterventionellen Therapie von Vorhofflimmern}

\subsubsection{Schnelles Erkennen und erfolgreiche Behandlung der Ösophagusperforation nach Hochfrequenzablation von Vorhofflimmern}

Zitierweise:

Nikolaos Dagres, M.D., Hans Kottkamp, M.D., PH.D., Christopher Piorkowski, M.D., Nicolas Doll, M.D., Friedrich Mohr, M.D., PH.D., Marc Horlitz, M.D., Dimitrios Th. Kremastinos, M.D., and Gerhard Hindricks, M.D., PH.D.

Rapid Detection and Successful Treatment of Esophageal Perforation After Radiofrequency Ablation of Atrial Fibrillation: Lessons from Five Cases

J Cardiovasc Electrophysiol, Vol. 17, pp. 1213-1215, November 2006. 


\title{
Rapid Detection and Successful Treatment of Esophageal Perforation After Radiofrequency Ablation of Atrial Fibrillation: Lessons from Five Cases
}

\author{
NIKOLAOS DAGRES, M.D., ${ }^{*}$ HANS KOTTKAMP, M.D., PH.D., $\dagger$ CHRISTOPHER PIORKOWSKI, \\ M.D., $\dagger$ NICOLAS DOLL, M.D. $\ddagger$ FRIEDRICH MOHR, M.D., PH.D. $\ddagger$ MARC HORLITZ, M.D.,$\S$ \\ DIMITRIOS TH. KREMASTINOS, M.D., ${ }^{*}$ and GERHARD HINDRICKS, M.D., PH.D. $\dagger$
}

From the *University of Athens, Second Cardiology Department, Attikon University Hospital, Athens, Greece; †University of Leipzig, Heart Center, Department of Electrophysiology, Leipzig, Germany; łUniversity of Leipzig, Heart Center, Clinic for Cardiac Surgery, Leipzig, Germany; and §University of Witten/Herdecke, Heart Center Wuppertal, Department of Cardiology, Wuppertal, Germany

\begin{abstract}
Esophageal Perforation After AF Ablation. Introduction: The aim of the study was to identify criteria for rapid recognition and successful treatment of esophageal perforation after radiofrequency ablation for atrial fibrillation (AF).

Methods and Results: Esophageal perforation occurred in five patients after intraoperative $(n=4)$ or percutaneous $(n=1)$ AF ablation. Patients presented with high fever $(n=3)$ or severe chest/epigastric pain $(\mathrm{n}=2)$ 8-28 days after ablation. WBC count was elevated at presentation in all patients $(15,460 \pm 2,910 / \mu \mathrm{L})$, CRP showed a delayed rise. Thoracic CT detected free air in all. Neurologic complications occurred in three cases $(60 \%)$ with a delay of 5-40 hours after first symptoms. Only one $(20 \%)$ developed neurologic complications within the first 24 hours. Two patients $(40 \%)$ died before surgery could be performed. In both, time from symptom onset to diagnosis was significant ( 24 and 36 hours). Three patients $(60 \%)$ underwent esophageal resection and survived. In two of them, treatment was rapid with time from symptoms to surgery of 24 hours; they had favorable outcome. In the third surviving patient, surgery was late ( 5 days after first symptoms); permanent neurologic residues remained.

Conclusion: The leading symptom of esophageal perforation is high fever or severe chest/epigastric pain. Fever is not necessarily present. Leukocytosis is the earliest and most sensitive laboratory marker, thoracic CT the most valuable diagnostic examination. The dramatic neurologic complications occur with a delay of at least a few hours after first symptoms. Immediate surgery may prevent neurologic complications and could possibly result in a high survival rate without residues. Delay of treatment seems to have devastating results. (J Cardiovasc Electrophysiol, Vol. 17, pp. 1213-1215, November 2006)
\end{abstract}

catheter ablation, atrial fibrillation

\section{Introduction}

Esophageal perforation is an uncommon but lifethreatening complication after radiofrequency (RF) ablation for atrial fibrillation (AF). ${ }^{1-7}$ It is caused by thermal injury due to the close vicinity of the esophagus to the posterior left atrial wall, ${ }^{8}$ was originally described after intraoperative ablation, ${ }^{1,2}$ but can also occur after percutaneous ablation..$^{3-7}$ Diagnosis is challenging and often received after death. ${ }^{5}$

Due to the high mortality, criteria for rapid detection and successful treatment would be particularly important. Existing reports are mostly descriptive. A systematic analysis, especially regarding the time course of clinical signs and laboratory markers that can lead to diagnosis, is lacking. We report our experience from five patients with esophageal perforation after AF ablation. Some procedure-associated and surgical aspects have been described previously. ${ }^{2,7}$ In the present

Address for correspondence: Nikolaos Dagres, M.D., Second University Cardiology Department, Attikon University Hospital, Rimini 1, Haidari, 12462 Athens, Greece. Fax: +302105832351; E-mail: nikolaosdagres@ yahoo.de

Manuscript received 10 June 2006; Revised manuscript received 20 July 2006; Accepted for publication 24 July 2006.

doi: $10.1111 / \mathrm{j} \cdot 1540-8167.2006 .00611 . \mathrm{x}$ report, we focus on clinical features and laboratory markers that allow early recognition and treatment.

\section{Methods}

Esophageal perforation occurred in five cases: in 4 of 387 consecutive patients undergoing intraoperative ablation $(1.0 \%)$ and 1 of 464 consecutive patients undergoing percutaneous ablation $(0.2 \%)$ in our institutions $(P=0.30$, chi-square test). Gender was male in 4 cases $(80 \%)$, mean age was $51 \pm$ 18 (range 35-76) years.

Intraoperative ablation was performed using minimally invasive techniques. ${ }^{9}$ A specially designed ablation probe (Osypka GmbH, Grenzach-Wyhlen, Germany) with a 10-mm T-shaped tip was used for temperature-guided RF energy application. Contiguous lesion lines were placed under direct vision between the mitral annulus and the left lower pulmonary vein, further to the left upper pulmonary vein, from there to the right upper pulmonary vein, and then to the right lower pulmonary vein.

Finally, the line at the left atrial roof was connected to the surgical incision. All lesions were endocardial. Preselected catheter tip temperature was $60^{\circ} \mathrm{C}$, maximum power was $50 \mathrm{~W}$.

Percutaneous procedures were performed with an electromagnetic mapping system (Carto, Biosense Webster, CA, 
USA). Circular RF lesions were placed in the left atrium around the left and right pulmonary veins, as well as linear lesions between the encircling lines, and from the left circle to the mitral annulus. ${ }^{10}$ For temperature-guided RF energy application, we used either an ablation catheter with $8-\mathrm{mm}$ tip with preselected catheter tip temperature of $60^{\circ} \mathrm{C}$ and maximum power of $60 \mathrm{~W}$ or a $3.5-\mathrm{mm}$ irrigated tip catheter with preselected temperature of $50^{\circ} \mathrm{C}$ and maximum power of $50 \mathrm{~W}$.

Data are expressed as mean $\pm \mathrm{SD}$.

\section{Results}

\section{Clinical Symptoms}

Onset of symptoms occurred between the 8 th and the 28 th postprocedural day. Patients presented with two distinct main symptoms: (1) high fever between 39.6 and $40^{\circ} \mathrm{C}$ in three cases $(60 \%),(2)$ sudden and severe chest or epigastric pain in the other two cases $(40 \%)$. Of the two patients presenting with pain, one had elevated temperature $\left(38.0^{\circ} \mathrm{C}\right)$, while the other had normal temperature.

Neurologic symptoms developed in three of the five patients $(60 \%)$ : transient hemiparesis $(\mathrm{n}=3)$, grand mal seizures $(n=1)$, and aphasia $(n=1)$. In these three cases, time interval between onset of first symptoms associated with perforation and onset of neurologic complications was 5, 32, and 40 hours. In the two patients who did not develop neurologic complications, diagnosis was set rapidly, followed by surgery approximately 24 hours after the first general symptoms. Thus, at the onset of first symptoms, neurologic dysfunction was not present in any patient and only one of the five patients $(20 \%)$ developed neurologic symptoms within the first 24 hours.

\section{Diagnostic Evaluation}

Thoracic CT detected free air in all five patients (100\%): in the mediastinum $(n=3)$, the pericardium $(n=1)$, and the left atrium $(n=1)$.

One patient developed hemoptysis, and gastroscopy was performed. Following air insufflation via the gastroscope, the patient developed massive cerebral air embolization and subsequently died.

\section{Laboratory Markers}

Leukocytosis was the earliest and most sensitive laboratory marker, being present in all patients at presentation. WBC count at presentation was $15,460 \pm$ $2,910 / \mu \mathrm{L}$ (range $12,100-19,500$ ), rising to maximal values of $16,720 \pm 2,450 / \mu \mathrm{L}$ (range $13,400-19,500$ ).

On the contrary, CRP was not especially helpful for the diagnosis. CRP was measured in four patients at presentation and was elevated in all $(100 \%)$. Values were initially only mildly to moderately elevated $(4.2 \pm 3.2 \mathrm{mg} / \mathrm{dL}$, range $1.4-8.6 \mathrm{mg} / \mathrm{dL}$ ), rising to significantly elevated levels with a delay, compared with WBC count or body temperature. Maximal CRP levels were $14.7 \pm 15.9 \mathrm{mg} / \mathrm{dL}$ (range $2.1-35.7 \mathrm{mg} / \mathrm{dL})$.

\section{Outcome}

Of the five patients, two died ( $40 \%$ ) before surgery could be performed. In both, delay between symptom onset and diagnosis was significant: approximately 24 and 36 hours. As mentioned, one patient died following gastroscopy. In the other, rapid neurologic complications contributed significantly to deterioration. Autopsy confirmed the diagnosis of atrio-esophageal fistula and revealed multiple embolic infarctions in the brain and in other organs.

The remaining three patients $(60 \%)$ underwent extensive surgical esophageal resection and survived. Surgery confirmed the diagnosis showing necrosis of the posterior left atrial wall and perforation of the esophagus. The first patient had a complicated course with two additional surgical interventions due to recurrent fistulas, multiple septicemias and a Guillain-Barré-syndrome. This patient was the first who developed esophageal perforation and diagnosis was made very late, with time from first symptoms to surgery of 5 days. He suffers from significant gastrointestinal and neurologic deficits. The other two patients had a significantly better outcome. In both, esophageal resection was performed within 24 hours after symptom onset.

\section{Discussion}

Previous reports of esophageal perforation are descriptive, mostly limited to few cases. ${ }^{1,3,4,6,7}$ A systematic analysis of characteristic features, especially the time course of clinical signs and laboratory markers, which can guide detection and treatment, is lacking. Several important conclusions can be drawn from our series:

(1) Although some symptoms may be general and nonspecific, patients with esophageal perforation report two distinct main symptoms at presentation: high fever and/or severe chest or epigastric pain with sudden onset. Fever is not necessarily present. (2) The complication may occur 1 to 4 weeks after the procedure. (3) Leukocytosis is the most sensitive laboratory marker and is present in all cases at presentation. CRP is not especially helpful for diagnosis, since it rises to significantly elevated levels with a delay. (4) Thoracic CT is the most reliable diagnostic examination. (5) Early detection of the complication is crucial, since the potentially devastating neurologic complications occur with a delay of at least a few hours after the first symptoms. (6) Immediate surgery within a few hours after symptom onset may prevent the manifestation of neurologic complications and could possibly result in a high survival rate without residues. Delay of surgery seems to have devastating results. (7) Attempts to visualize suspected fistulas or to perform gastroscopy in patients presenting with hemoptysis following AF ablation should be avoided due to a significant risk of air embolization.

Our findings are in general consistent with previous reports. . $^{1,3-6}$ What is new is the important observation that neurologic complications seem to occur with a significant delay after the first general symptoms. Up to now, no report has focused on this point. Avoiding delay is crucial for patient management, since early surgery may prevent the manifestation of the neurologic complications that dramatically worsen prognosis. Mortality in our series was $40 \%$, with two of the five patients dying, in contrast to the series of Cummings et al., who reported a fatal outcome in all nine described cases $(100 \%){ }^{5}$ In that series, neurologic complications developed in eight of the nine patients, but data on the time point of first neurologic involvement are not available. Since only four of the nine patients received correct diagnoses before death, we may assume that there was a 
significant delay in diagnosis. This time factor could possibly explain the difference in mortality and the high percentage of neurologic involvement.

We absolutely confirm the suggestion of Pappone et al. ${ }^{3}$ that antibiotic therapy alone is not sufficient as treatment. Temporary esophageal stenting combined with intravenous antibiotic therapy allowed healing in a case reported recently. ${ }^{6}$ Whether this approach can replace surgical treatment remains to be seen.

Leukocytosis was the earliest and most sensitive laboratory marker in our cases. Obviously, an elevated WBC count is not specific for esophageal perforation. However, leukocytosis in the presence of the described symptoms in the first weeks after AF ablation must alarm the physician.

The rate of esophageal perforation after surgery and after catheter ablation did not differ significantly. However, the small number of patients developing the complication does not allow a reliable assessment of possible differences in the perforation risk in surgical and percutaneous procedures.

Clinical studies showed the high variability of the location of the esophagus in relation to the left atrium and the pulmonary veins. ${ }^{11,12}$ To avoid esophageal damage during ablation, reduction of RF generator power has been suggested. ${ }^{3}$ The power settings that we used were in general consistent with the recommendations of other investigators. ${ }^{3}$ Nevertheless, it was recently demonstrated that power is only a weak predictor of esophagus temperature during ablation and that even power settings $<10 \mathrm{~W}$ may generate increased esophagus luminal temperatures. ${ }^{13}$ Esophageal temperature monitoring during ablation may help reduce the perforation risk. $^{12}$

\section{Limitations}

We must stress that four of the reported patients underwent intraoperative ablation. Theoretically, the course of these patients might vary, compared with patients undergoing percutaneous procedures. However, the findings in patients with intraoperative ablation in our series were identical with the patient with percutaneous ablation and consistent with other published cases. Therefore, we may assume that our findings are representative for all patients undergoing RF ablation for AF.

\section{Conclusion}

There are two leading symptoms in patients with esophageal perforation: high fever or severe chest/epigastric pain with sudden onset. Fever is not necessarily present. Leukocytosis is the most sensitive laboratory marker and is present in all cases at presentation. CRP shows a delayed rise to significant levels. Thoracic CT is the most valuable diagnostic examination. Neurologic complications occur with a delay of at least few hours after first symptoms. Therefore, immediate surgical treatment is crucial, may prevent neurologic complications, and could possibly result in a high survival rate without residues. Delay of surgery seems to have devastating results, with high mortality or survival with permanent residues.

\section{References}

1. Gillinov AM, Pettersson G, Rice TW: Esophageal injury during radiofrequency ablation for atrial fibrillation. J Thorac Cardiovasc Surg 2001:122:1239-1240.

2. Doll N, Borger MA, Fabricius A, Stephan S, Gummert J, Mohr FW, Hauss J, Kottkamp H, Hindricks G: Esophageal perforation during left atrial radiofrequency ablation: Is the risk too high? J Thorac Cardiovasc Surg 2003; 125:836-842.

3. Pappone C, Oral H, Santinelli V, Vicedomini G, Lang CC, Manguso F, Torracca L, Benussi S, Alfieri O. Hong R, Lau W. Hirata K, Shikuma N. Hall B, Morady F: Atrio-esophageal fistula as a complication of percutaneous transcatheter ablation of atrial fibrillation. Circulation 2004;109:2724-2726.

4. Scanavacca MI, D’Ávila A, Parga J, Sosa E: Left atrial-esophageal fistula following radiofrequency catheter ablation of atrial fibrillation. J Cardiovasc Electrophysiol 2004;15:960-962.

5. Cummings JE, Schweikert RA, Saliba WI, Burkhardt JD, Kilikaslan F, Saad E, Natale A: Atrial-esophageal fistulas after radiofrequency ablation. Ann Intern Med 2006;144:572-574.

6. Bunch TJ, Nelson J, Foley T, Allison S, Crandall BG, Osborn JS, Weiss JP, Anderson JL, Nielsen P, Anderson L, Lappe DL, Day JD: Temporary esophageal stenting allows healing of esophageal perforations following atrial fibrillation ablation procedures. J Cardiovasc Electrophysiol 2006; 17:435-439.

7. Schley P, Gülker H, Horlitz M: Atrio-esophageal fistula following circumferential pulmonary vein ablation: Verification of diagnosis with multislice computed tomography. Europace 2006;8:189190.

8. Lemola K, Sneider M, Desjardins B, Case I, Han J, Good E, Tamirisa K, Tsemo A, Chugh A, Bogun F, Pelosi F Jr, Kazerooni E, Morady F, Oral H: Computed tomographic analysis of the anatomy of the left atrium and the esophagus: Implications for left atrial catheter ablation. Circulation 2004;110:3655-3660.

9. Kottkamp H. Hindricks G, Autschbach R, Krauss B, Strasser B, Schirdewahn P, Fabricius A, Schuler G, Mohr FW: Specific linear left atrial lesions in atrial fibrillation: Intraoperative radiofrequency ablation using minimally invasive surgical techniques. J Am Coll Cardiol 2002:40:475-480.

10. Kottkamp H, Tanner H, Kobza R, Schirdewahn P, Dorszewski A, GerdsLi JH, Carbucicchio C, Piorkowski C, Hindricks G: Time courses and quantitative analysis of atrial fibrillation episode number and duration after circular plus linear left atrial lesions: Trigger elimination or substrate modification: Early or delayed cure? J Am Coll Cardiol 2004; $44: 869-877$.

11. Kottkamp H, Piorkowski C, Tanner H, Kobza R, Dorszewski A, Schirdewahn P, Gerds-Li JH, Hindricks G: Topographic variability of the esophageal left atrial relation influencing ablation lines in patients with atrial fibrillation. J Cardiovasc Electrophysiol 2005;16:146150.

12. Redfearn DP, Trim GM, Skanes AC, Petrellis B, Krahn AD, Yee R, Klein GJ: Esophageal temperature monitoring during radiofrequency ablation of atrial fibrillation. J Cardiovasc Electrophysiol 2005;16:589593.

13. Cummings JE, Schweikert RA, Saliba WI, Burkhardt JD, Brachmann J, Gunther J, Schibgilla V, Verma A, Dery M, Drago JL, Kilicaslan F, Natale A: Assessment of temperature, proximity, and course of the esophagus during radiofrequency ablation within the left atrium. Circulation 2005; 112:459-464. 
4.3. Risiken der katheterinterventionellen Therapie von Vorhofflimmern

4.3.3. Einfluss der topographische Variabilität der anatomischen Beziehung zwischen Ösophagus und linkem Vorhof auf die Ablationslinien bei Patienten mit Vorhofflimmern

Zitierweise:

Hans Kottkamp, M.D., Christopher Piorkowski, M.D., Hildegard Tanner, M.D., Richard Kobza, M.D., Anja Dorszewski, M.D., Petra Schirdewahn, M.D., Jin-Hong Gerds-Li, M.D., and Gerhard Hindricks, M.D.

Topographic Variability of the Esophageal Left Atrial Relation Influencing Ablation Lines in Patients with Atrial Fibrillation.

J Cardiovasc Electrophysiol, Vol. 16, pp. 146-150, February 2005. 


\title{
Topographic Variability of the Esophageal Left Atrial Relation Influencing Ablation Lines in Patients with Atrial Fibrillation
}

\author{
HANS KOTTKAMP, M.D., CHRISTOPHER PIORKOWSKI, M.D., HILDEGARD TANNER, M.D., \\ RICHARD KOBZA, M.D., ANJA DORSZEWSKI, M.D., PETRA SCHIRDEWAHN, M.D., \\ JIN-HONG GERDS-LI, M.D., and GERHARD HINDRICKS, M.D.
}

From the Department of Electrophysiology, Heart Center, Cardiology, University of Leipzig, Leipzig, Germany

\begin{abstract}
Topography of the Esophagus in Atrial Fibrillation Ablation. Introduction: The close anatomic relationship of the posterior wall of the left atrium (LA) and the thermosensitive esophagus creates a potential hazard in catheter ablation procedures.

Methods and Results: In 30 patients (pts) with atrial fibrillation (AF) undergoing catheter ablation, we prospectively studied the course and contact of the esophagus in relation to LA and the topographic proximity to ablation lines encircling the right-sided and left-sided pulmonary veins $(\mathrm{PV})$ as well as to the posterior line connecting the encircling lines using the electromagnetic mapping system for reconstruction of LA and for tagging of the esophagus. This new technique of anatomic tagging of the esophagus was validated against the $\mathrm{CT}$ scan as a standard imaging procedure. The esophageal course was highly variable, extending from courses in direct vicinity to the left- or right-sided PV as well as in the midportion of the posterior LA. In order to avoid energy application in direct proximity to the esophagus, adjustments of the left and right $P V$ encircling lines were necessary in $14 / 30$ pts $(47 \%)$ and $3 / 30(10 \%)$. In 30 pts $(100 \%)$, the midto inferior areas of the posterior LA revealed contact with the esophagus. Therefore, posterior and inferior linear ablation lines were abandoned and shifted to superior in 29 pts (97\%).

Conclusions: Anatomic tagging of esophagus revealed a highly variable proximity to different areas of the posterior LA suggesting individual adjustment of encircling and linear ablation lines in $\mathrm{AF}$ ablation procedures to avoid the life threatening complication of esophagus perforation. (J Cardiovasc Electrophysiol, Vol. 16, pp. 146-150, February 2005)
\end{abstract}

catheter ablation, atrial fibrillation, esophagus, mapping, anatomy

Interventional ablation strategies for curative treatment of atrial fibrillation (AF) are targeting at the pathophysiological cornerstones of AF, i.e., the initiating triggers and/or the perpetuation of the arrhythmia. ${ }^{1-6}$ Percutaneous catheter ablation with radiofrequency (RF) energy induced lines encircling the pulmonary veins (PV) outside the PV at the atrial level and/or placement of linear lesions lines connecting the circles and the mitral annulus revealed promising results and is being used increasingly. ${ }^{7-9}$ Applying these strategies, RF energy application may occur in close vicinity of the esophagus. Using intraoperative application of RF energy for treatment of AF, esophageal perforations and creation of esophageal left atrial fistula have been reported and have indicated a high mortality of this severe complication. ${ }^{5,10}$ Very recently, this life threatening complication has also been reported following percutaneous catheter ablation. ${ }^{11,12}$

In the present study, the course and proximity of the esophagus in relation to the left atrium (LA) and the topographic

Address for correspondence: Hans Kottkamp, M.D., Dept. of Electrophysiology, Heart Center, Cardiology, University of Leipzig, Struempellstrasse 39, D-04289 Leipzig, Germany. Fax: +49-341-865-1460; E-mail: kotth@medizin.uni-leipzig.de

Drs Kottkamp and Hindricks have received funding from BiosenseWebster, Inc., which supported this study in part by an unrestricted educational grant. Dr Tanner was supported by a grant from the Swiss National Research Foundation

Manuscript received 24 August 2004; Revised manuscript received 10 October 2004; Accepted for publication 28 October 2004.

doi: $10.1046 / j .1540-8167.2005 .40604 . x$ proximity to ablation lines encircling the PV as well as to the posterior line connecting the encircling lines were investigated using the electromagnetic mapping system for reconstruction of the LA and for tagging of the esophagus. In addition, the necessity of individual adjustment of the line placement to avoid the life threatening complication of esophagus perforation was prospectively tested.

\section{Methods}

\section{Patient Population}

In this prospective study, 30 consecutive patients $(55 \pm$ 11 years old $)$ with paroxysmal $(n=21)$ or persistent $(n=$ 9) AF were included. As an inclusion criterion, all patients were highly symptomatic despite multiple antiarrhythmic drug treatment regimens. Left heart catheterization, transthoracic/transesophageal echocardiography, and spiral CT scan were performed before ablation. All patients gave written informed consent on the investigational nature of the procedure that was approved by the institutional review committee.

\section{Mapping/Tagging and Ablation Procedure}

The electromagnetic mapping system(CARTO, BiosenseWebster, Waterloo, Belgium) was used for reconstruction of the LA and PV, navigation of the ablation catheter (Navistar, BiosenseWebster), and for tagging of the ablation sites. The mean number of points obtained per case for anatomy reconstruction before starting ablation was 50 .

In addition, tagging of the esophagus was performed after LA reconstruction prior to ablation using a second CARTO catheter, advanced through a conventional gastric tube into 


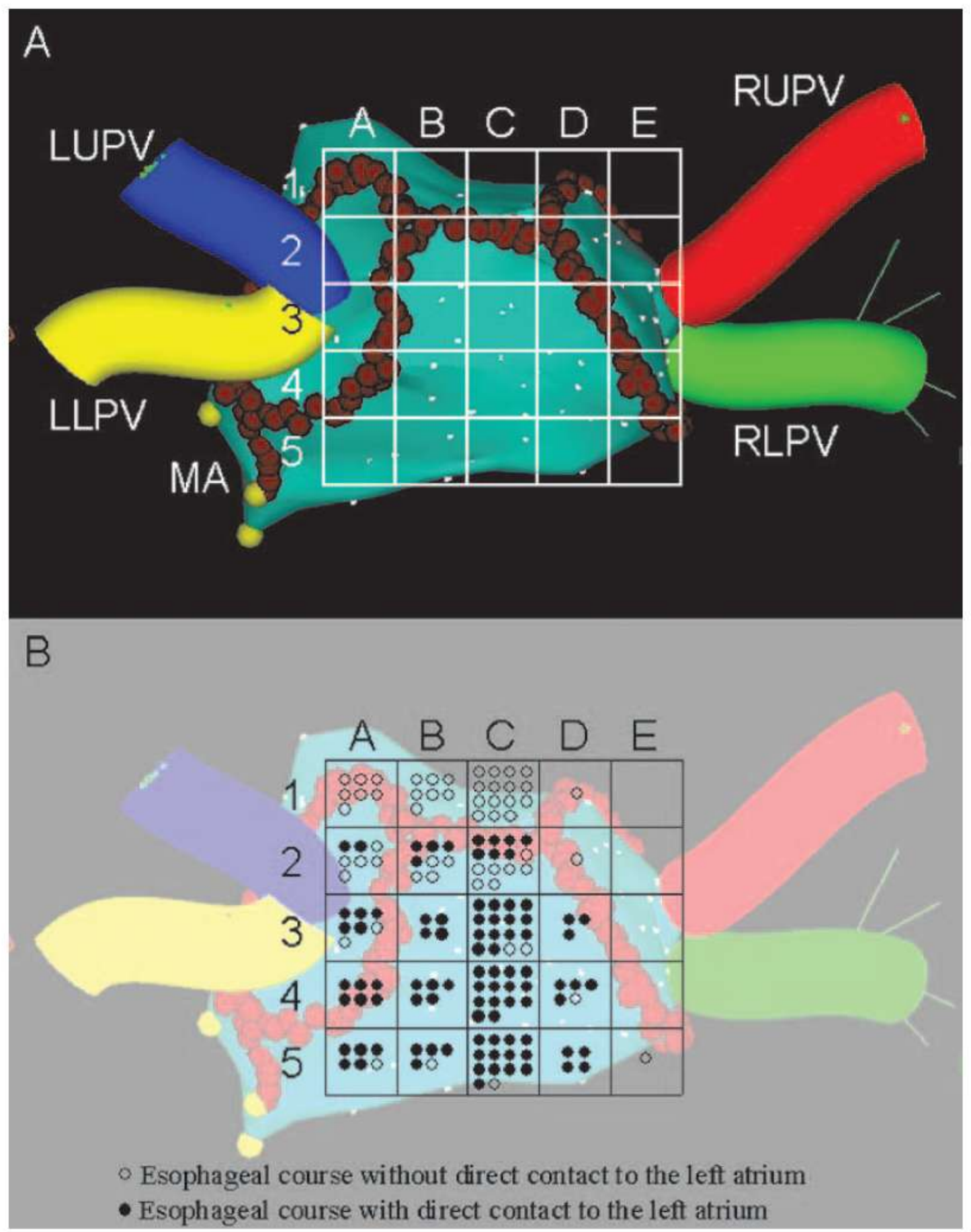

Figure 1. A: Postero-anterior view of an electroanatomic reconstruction of the left atrium (LA) including the pulmonary veins (PV). Superimposition of a grid with vertical columns A-E and horizontal rows 1-5. Red dots represent ablation sites ( $L L P V=$ left lower PV; LUPV $=$ left upper PV; MA = mitral annulus; RLPV = right lower PV; RUPV = right upper PV). B: The courses of the esophagus and areas with direct contact of the esophagus with the LA in the 22 patients are given with open and filled circles, respectively.

the esophagus. Esophagus ("vessel") tagging was started while slowly withdrawing the catheter.

Contact of the esophagus to the LA was defined when the reconstructed esophageal tube directly followed the posterior wall of the reconstructed LA, best seen in a lateral and cranial view. RF energy induced circumferential plus linear lesions were combined and percutaneously placed in the LA around the left and right PV, between the encircling lines and from the left circle to the mitral annulus (Fig. 1). Individual adjustment of the posterior aspects of the encircling lines as well as the posterior line was performed as indicated from the esophageal course to prevent RF application in direct proximity to the esophagus (Fig. 2). A distance of at least $5 \mathrm{~mm}$ from the esophagus tag was used for all ablation lines.

$\mathrm{RF}$ ablation was performed during sinus rhythm. The endpoint of the procedure was the completion of the proposed 

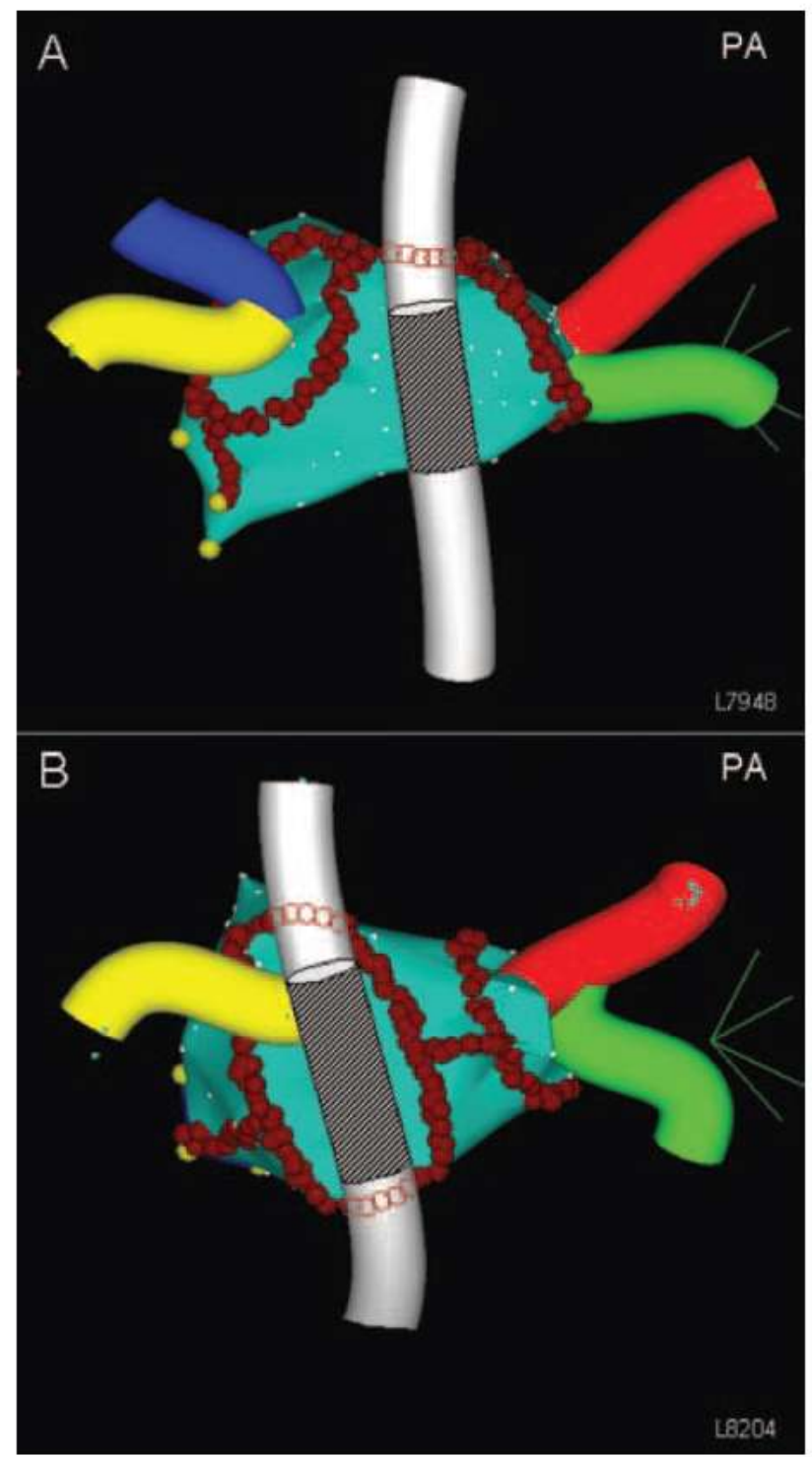

Figure 2. A: Example of an electroanatomic reconstruction of the left atrium (LA) including tagging of the esophagus (gray tube) demonstrating a typical esophageal course in column $C$, with direct esophageal left atrial contact (hatched area) in the mid-and inferior aspects of the posterior LA (rows 3-5) necessitating placement of the connecting linear lesion superior. B: Example of an electroanatomic reconstruction of the $L A$ with an esophageal course in column A, with extended esophageal left atrial contact (hatched area) in the mid-and inferior aspects of the posterior LA (rows 2-5), necessitating adjustment of the left encircling line. This was the only patient, where an adjustment of the connecting linear lesion from a posterior to a more superior position was not necessary. Of note, this patient had a common ostium of left $P V(P A=$ posterior-anterior $)$.

encircling and linear lesions whereas definite isolation of the PV and/or complete left atrial isthmus block were not required prerequisites of the procedure. However, the investigators clearly tried to place the lines as continuous and transmural as possible.

\section{CT Imaging Technique}

Before ablation, all patients received a cardiac CT imaging on a multidetector four-row helical system (Somatom Volume
Zoom, Siemens Medical Systems, Forchheim, Germany) as a standard imaging procedure. Data acquisition was performed in late diastole at a slice width of $2 \mathrm{~mm}$ and a reconstruction increment of $1 \mathrm{~mm}$. Coverage was completed within one breath-hold period (25-30 seconds). Imaging was initiated at the transaxial level of the aortic arch and carried caudally to cover the cardiac chambers. Nonionic iodinated contrast material (Imeron 300) was administered intravenously $(80 \mathrm{~mL}$, $2.5 \mathrm{~mL} / \mathrm{sec}$ ). The image data were reviewed using multiplanar reconstruction, maximal intensity projection, and 3D volume rendering. Abnormal conditions influencing the course of the esophagus (e.g., esophageal tumors or hernias) were excluded on the CT scan for all patients.

\section{Validation of the Esophageal Topography on CARTO with CT Imaging}

With both techniques, the posterior wall of the LA was divided into a grid with vertical columns $\mathrm{A}-\mathrm{E}$ and horizontal rows 1-5 (Fig. 1). The course of the esophagus throughout this grid was analyzed. Furthermore, the fields of contact between esophagus and LA were assessed within the grid. The average width of the esophagus on CT was $12 \pm 2 \mathrm{~mm}$ and matched the diameter of the cover tube of the esophageal tag in CARTO measuring $10 \mathrm{~mm}$ and, thereby, allowed comparison of area of contact. For validation of the electroanatomic reconstruction, the fields with course and/or contact on the CT scan were set as gold standard. Both analysis (CT and CARTO) were performed blinded and independently by two investigators.

\section{Statistics}

Results are expressed as mean (SD), or numbers and percentages, as appropriate. Esophageal courses of all patients in columns A-E were compared by chi-square test. A P value of less than 0.05 was considered statistically significant.

\section{Results}

\section{Esophageal Course and Contact with the Left Atrium}

In most patients, the esophagus descended medially behind the LA (Fig. 1). In 10 patients, a slightly oblique course was observed. However, esophageal courses differed significantly between patients: $63 \%$ were in column C, $37 \%$ were in column $\mathrm{A}, \mathrm{B}, \mathrm{D}$, and/or $\mathrm{E}(\mathrm{P}<0.01)$. Esophageal courses in columns $\mathrm{A}$ and $\mathrm{B}$ were more frequently observed than in columns D and E (Fig. 1) $(\mathrm{P}=0.02)$.

Typically, the esophagus descended strictly posterior to the LA behind the superior and mid areas of the LA and then bended toward anterior behind the posterior/inferior areas of the LA at rows 3-5 (Figs. 1 and 2). Therefore, no patients ( $0 \%)$ and only 13 patients $(43 \%)$ revealed esophagus-left atrial contact in rows 1 and 2, respectively. In contrast, in rows 3-5, esophagus-left atrial contact was observed in 25 (83\%), 29 $(97 \%)$, and 26 patients $(87 \%)$, respectively.

\section{Adjustment of the Circumferential and/or Linear Lesion Lines}

In all 30 patients (100\%), esophagus-left atrial contact was observed at some point in rows 3-5 (see above). Therefore, strictly posterior and inferior linear lesions connecting the encircling lines had to be completely abandoned, with the 


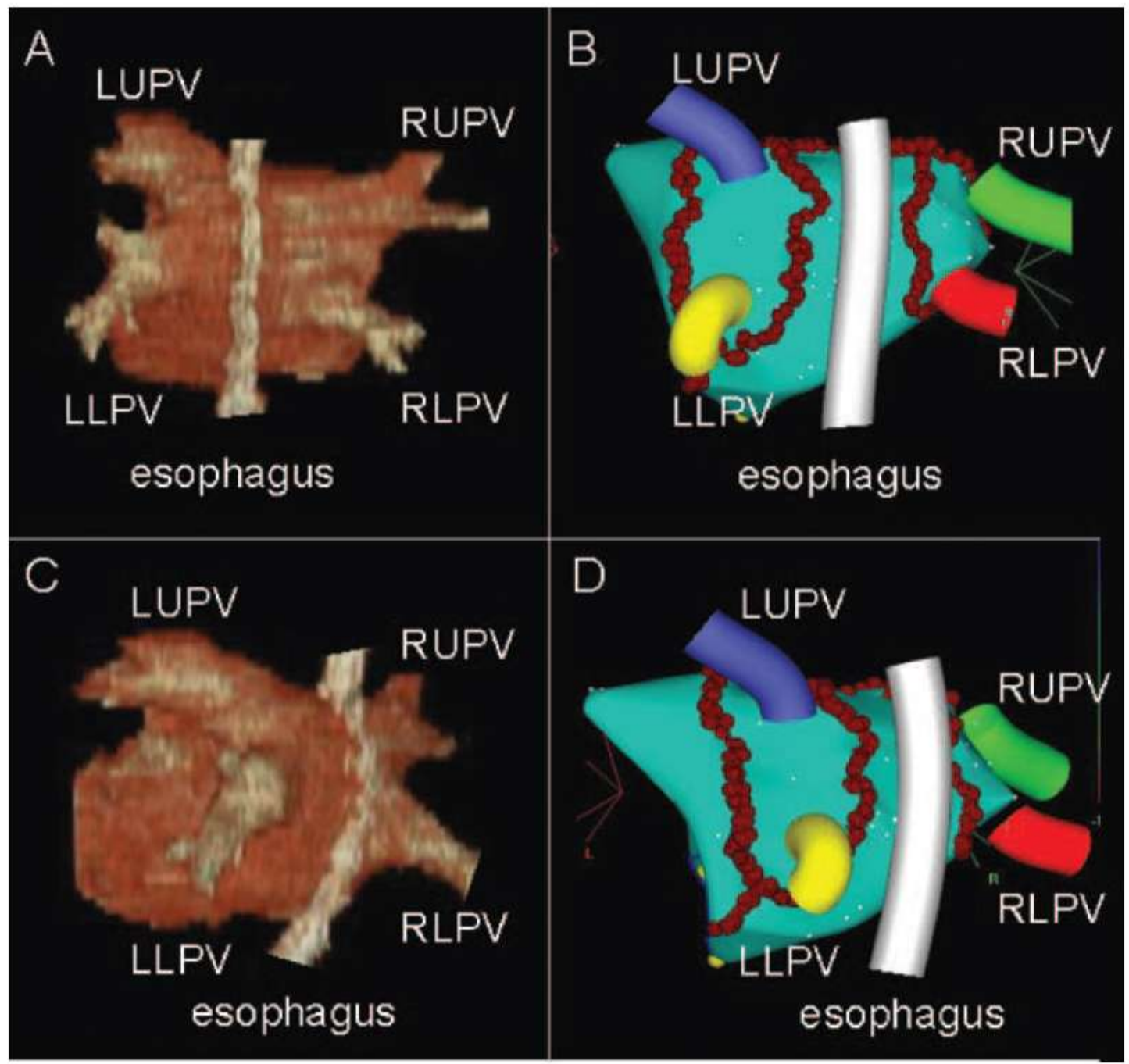

Figure 3. A: Example of a CT reconstruction of the $L A$, the pulmonary veins, and the esophagus, filled with barium in posterior view. B: The electroanatomic reconstruction of the LA including taggings of the pulmonary veins and the esophagus (gray tube) of the same patient in the same view is given. Red dots represent ablation sites. C and D: Left posterior oblique projection of CT reconstruction and CARTO map of the LA, the pulmonary veins, and the esophagus in the same patient as in $A$ and $B$, illustrating the high concordance of the electroanatomic reconstruction of the esophageal course and contact with the $L A$ with the CT reconstruction $(L L P V=$ left lower $P V ; L U P V=$ left upper $P V ; R L P V=$ right lower $P V ; R U P V=$ right upper $P V)$.

exception of one patient whose esophageal course was shown in column A (Fig. 2B). Instead, the connecting linear line was placed in $29(97 \%)$ patients superior in rows 1 or 2 where no esophagus-left atrial contact was observed.

In $14 / 30$ patients $(47 \%)$, esophagus-left atrial contact was observed in columns A or B and, therefore, necessitated adjustment of the posterior aspect of the left encircling line. In $3 / 30$ patients $(10 \%)$, esophagus-left atrial contact was observed in columns D or E necessitating adjustment of the posterior aspect of the right encircling line. Altogether, 57\% of all encircling lines were adjusted.

\section{Comparison Between Electroanatomic Mapping (CARTO) and CT Scans}

With respect to the esophageal course, CARTO showed a $100 \%$ concordance compared to the CT scans in 24 of our 30 patients $(80 \%)$. The discordance was $1 / 5$ fields in 2 patients, $2 / 5$ fields in 3 patients, and $3 / 5$ fields in 1 patient, respectively. On average, the esophageal course on CARTO showed $93 \pm 16 \%$ concordance to the CT scans. In all patients with less than $100 \%$ concordance, the esophagus exhibited a slightly oblique course crossing from one column to another. However, in all of these patients the discordant fields differed maximally by one column only, e.g., A instead of B.

With respect to the esophageal contact, CARTO showed a $100 \%$ concordance compared to the CT scan in 22 of our 30 patients $(73 \%)$. The discordance was $1 / 4$ contact fields in 3 patients, $1 / 3$ contact fields in 2 patients, $2 / 4$ contact fields in 1 patient, $3 / 4$ contact fields in 1 patient, and $4 / 4$ contact fields in 1 patients, respectively. In the last patient, overlapping between neighboring columns lead to this discrepancy. On average, the distribution of the esophageal contact on the CARTO grid showed $88 \pm 25 \%$ concordance to the CT scans. In all patients with less than $100 \%$ concordant contact, again, the affected fields differed maximally by one column or one row only. The high concordance of esophageal course and contact to the LA of CARTO with CT reconstruction is illustrated with a typical example (Fig. 3). 


\section{Discussion}

Percutaneous catheter ablation of AF with RF energy induced lines encircling the PV and/or placement of linear lesions lines connecting the circles and the mitral annulus revealed promising results and is increasingly used. ${ }^{7-9} \mathrm{Ap}-$ plying these strategies, RF energy applications may occur in close vicinity of the esophagus. Very recently, the life threatening complication of esophagus perforation has been reported following percutaneous catheter ablation. ${ }^{11,12}$

Using different strategies of intraoperative application of RF energy for curative treatment of AF, esophageal perforations and creation of esophageal left atrial fistula have been reported and have indicated a high mortality of this severe complication in the range of $50 \% .^{5,10}$ Although the absolute number of cases reported is relatively low, the percentage of this type of complication during intraoperative RF ablation may be as high as $1 \% .^{5,10}$ The high success rate in intraoperative ablation and the occurrence of this dramatic complication thereby may present two sides of the same coin. In the operation room, RF ablation probes can be applied under direct vision with excellent and stable probe-tissue contact pressure. These conditions allow optimized heat transfer and lead to transmural lesions. The contiguity and transmurality of lesion lines are the main cornerstones of successful ablation procedures provided that adequate strategies are applied. On the other side, transmural lesions may lead to heat transfer to the esophagus provided that RF energy is applied in areas of the posterior LA where the esophagus is in direct contact with the LA. Thermal damage of the esophagus may then lead to esophagus perforation or creation of esophagoleft atrial fistula. Typically, this type of complication became clinically overt 10 days after the operation. . $^{5,10}$

Contiguity and transmurality of the encircling and linear lesion lines are among the high demands in percutaneous catheter ablation procedures for isolation of the triggers and interruption of perpetuating re-entrant circuits. The availability of precise 3-dimensional mapping technologies with 8 -mm tip or cooled-tip ablation catheters increasingly allow the induction of transmural lesions. Thereby, the risk of esophagus perforation will certainly increase if this potential complication is not specifically addressed.

In the present prospective study, anatomic tagging of the esophagus revealed a highly variable proximity to different areas of the posterior LA. In addition, the mid- and inferior portion of the LA demonstrated direct contact with the esophagus in all patients. Therefore, individual adjustment of encircling and linear ablation lines was suggested in all patients undergoing AF ablation procedures to avoid RF energy applications in direct vicinity to the esophagus. Given the highly variable and individual course of the esophagus and the increasingly transmural RF-induced lesions, visualization of the esophagus seems mandatory in all patients undergoing circumferential and/or linear lesions placed in the posterior areas of the LA. Currently, anatomic tagging using the electromagnetic mapping system may be one effective way to adjust the circumferential and linear lesions to the in- dividual esophageal course, and a concordance of CT scans and electroanatomic tagging was found in our study. In the future, CT or MRT image integration could allow direct visualization of the esophagus guiding placement of the lesion lines to prevent this severe life threatening complication. At least equally important as increasing the efficacy, the control of complications is one of the paramount important aspects in the development of curative treatment of atrial fibrillation until we will finally take the "last big hurdle in treating supraventricular tachycardia."13

\section{References}

1. Haïssaguerre M, Jaïs P, Shah DC, Takahashi A, Hocini M, Quiniou G Garrigue S, Le Mouroux A, Le Metayer P, Clementy J: Spontaneous initiation of atrial fibrillation by ectopic beats originating in the PVs. N Engl J Med 1998;339:659-666.

2. Jaïs P, Shah DC, Haïssaguerre M, Takahashi A, Lavergne T, Hocini M, Garrigue S, Barold SS, Le Metayer P, Clementy J: Efficacy and safety of septal and left atrial linear ablation for atrial fibrillation. Am J Cardiol 1999:84:139R-146R

3. Pappone C, Rosanio S, Oreto G, Tocchi M, Gugliotta F, Vicedomini G, Salvati A, Dicandia C, Mazzone P, Santinelli V, Gulletta S, Chierchia S: Circumferential radiofrequency ablation of PV ostia. A new anatomic approach for curing atrial fibrillation. Circulation 2000;102:2619-2628.

4. Oral H, Knight BP, Tada H, Ozaydin M, Chugh A, Hassan S, Scharf C, Lai SW, Greenstein R, Pelosi F Jr, Strickberger SA, Morady F: PV isolation for paroxysmal and persistent atrial fibrillation. Circulation 2002;105:1077-1081.

5. Kottkamp H. Hindricks G, Autschbach R. Krauss B. Strasser B, Schirdewahn P, Fabricius A, Schuler G, Mohr FW: Specific linear left atrial lesions in atrial fibrillation: Intraoperative radiofrequency ablation using minimally invasive surgical techniques. J Am Coll Cardiol 2002;40:475480.

6. Ernst S, Ouyang F, Löber F, Antz M, Kuck KH: Catheter-induced linear lesions in the left atrium in patients with atrial fibrillation. $\mathrm{J}$ Am Coll Cardiol 2003:42:1271-1282.

7. Pappone C, Rosanio S, Augello G, Gallus G, Vicedomini G, Mazzone P, Gulletta S, Gugliotta F, Pappone A, Santinelli V, Tortoriello V, Sala S, Zangrillo A. Crescenzi G. Benussi S, Alfieri O, Manguso F, Landoni G, Lang C, Tomita T, Mesas C, Mastella E, Santinelli O, Dicandia C: Mortality, morbidity, and quality of life after circumferential pulmonary vein ablation for atrial fibrillation. J Am Coll Cardiol 2003; 42:185-197.

8. Oral H, Scharf C, Chugh A, Hall B, Cheung P, Good E, Veerareddy S, Pelosi F Jr, Morady F: Catheter ablation for paroxysmal atrial fibrillation. Segmental pulmonary vein ostial ablation versus left atrial ablation. Circulation 2003;108:2355-2360.

9. Pappone C, Santinelli V, Manguso F, Vicedomini G, Gugliotta F, Augello G, Mazzone P. Tortoriello V, Landoni G, Zangrillo A, Lang C, Tomita T, Mesas C, Mastella E, Alfieri O, Santinelli O, Gulletta S, Pappone A, Dicandia C, Rosanio S: Pulmonary vein denervation enhances long-term benefit after circumferential ablation for paroxysmal atrial fibrillation. Circulation 2004;109:327-334.

10. Gillinov M, Pettersson G, Rice TW: Esophageal injury during radiofrequency ablation of atrial fibrillation. J Thorac Cardiovasc Surg 2001:122:1239-1240.

11. Pappone C, Oral H, Santinelli V, Vicedomini G, Lang CC, Manguso F, Torracca L, Benussi S, Alfieri O, Hong R, Lau W, Hirata K, Shikuma N. Hall B, Morady F: Atrio-esophageal fistula as a complication of percutaneus transcatheter ablation of atrial fibrillation. Circulation 2004;109:2724-2726.

12. Scanavacca MI, D'Avila A, Parga J, Sosa E: Left atrial-esophageal fistola following radiofrequency catheter ablation of atrial fibrillation. $\mathrm{J}$ Cardiovasc Electrophysiol 2004;15:960-962.

13. Wellens HJJ: Atrial fibrillation-The last big hurdle in treating supraventricular tachycardia. N Engl J Med 1994;331:944-945. 
4.4. Einfluss der Vorhofflimmerperzeption auf das Monitoring nach Ablation

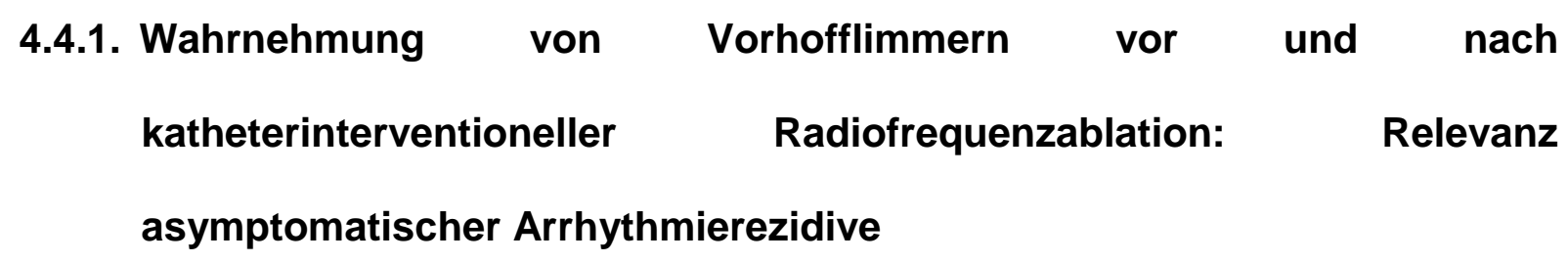

Zitierweise:

Gerhard Hindricks, MD; Christopher Piorkowski, MD; Hildegard Tanner, MD; Richard Kobza, MD; Jin-Hong Gerds-Li, MD; Corrado Carbucicchio, MD; Hans Kottkamp, MD.

Perception of Atrial Fibrillation before and after Radiofrequency Catheter Ablation: Relevance of Asymptomatic Arrhythmia Recurrence

Circulation. 2005; 112: 307-313. 


\title{
Perception of Atrial Fibrillation Before and After Radiofrequency Catheter Ablation Relevance of Asymptomatic Arrhythmia Recurrence
}

\author{
Gerhard Hindricks, MD; Christopher Piorkowski, MD; Hildegard Tanner, MD; \\ Richard Kobza, MD; Jin-Hong Gerds-Li, MD; Corrado Carbucicchio, MD; Hans Kottkamp, MD
}

Background-The objective of this study was to assess the incidence and impact of asymptomatic arrhythmia in patients with highly symptomatic atrial fibrillation (AF) who qualified for radiofrequency (RF) catheter ablation.

Methods and Results - In this prospective study, 114 patients with at least 3 documented AF episodes together with corresponding symptoms and an ineffective trial of at least 1 antiarrhythmic drug were selected for RF ablation. With the use of CARTO, circumferential lesions around the pulmonary veins and linear lesions at the roof of the left atrium and along the left atrial isthmus were placed. A continuous, 7-day, Holter session was recorded before ablation, right after ablation, and after 3, 6, and 12 months of follow-up. During each 7-day Holter monitoring, the patients recorded quality and duration of any complaints by using a detailed symptom log. More than 70000 hours of ECG recording were analyzed. In the 7-day Holter records before ablation, 92 of 114 patients (81\%) had documented AF episodes. All episodes were symptomatic in 35 patients $(38 \%)$. In 52 patients $(57 \%)$, both symptomatic and asymptomatic episodes were recorded, whereas in 5 patients $(5 \%)$, all documented AF episodes were asymptomatic. After ablation, the percentage of patients with only asymptomatic AF recurrences increased to $37 \%(P<0.05)$ at the 6-month follow-up. An analysis of patient characteristics and arrhythmia patterns failed to identify a specific subset who were at high risk for the development of asymptomatic AF.

Conclusions-Even in patients presenting with highly symptomatic AF, asymptomatic episodes may occur and significantly increase after catheter ablation. A symptom-only-based follow-up would substantially overestimate the success rate. Objective measures such as long-term Holter monitoring are needed to identify asymptomatic AF recurrences after ablation. (Circulation. 2005;112:307-313.)

Key Words: atrium $\mathbf{m}$ ablation $\mathbf{m}$ arrhythmia $\mathbf{m}$ fibrillation $\mathbf{m}$ follow-up studies

\begin{abstract}
A symptomatic or silent arrhythmia is a frequent condition in patients with atrial fibrillation (AF). ${ }^{1}$ The prevalence of asymptomatic AF found incidentally on clinical examination is $\approx 20 \% .^{1}$ Studies with transtelephonic arrhythmia monitoring or implantable monitoring devices have reported asymptomatic AF in up to $50 \%$ of patients evaluated. ${ }^{1,2}$ The patient cohorts observed in most of these studies participated in population surveys such as the Framingham Study, in antiarrhythmic drug trials, or in instances where monitoring followed pacemaker implantation for sinus node dysfunction or atrioventricular block. ${ }^{1.2}$ The incidence of asymptomatic arrhythmia in patients presenting with highly symptomatic $\mathrm{AF}$ who qualified for radiofrequency (RF) catheter ablation is unknown. Because AF catheter ablation is a new and potentially curative therapy and is currently performed in an increasing number of patients, data on asymptomatic $\mathrm{AF}$ in this subset of patients may have important implications for the overall success rate as well as for the individual patient
\end{abstract}

with regard to concomitant medical therapy, eg, oral anticoagulation. Thus, the present prospective study aimed to evaluate AF recurrences, particularly asymptomatic ones, in patients undergoing RF catheter ablation by repetitive, continuous, digital, long-term Holter ECGs.

\section{Methods}

\section{Patient Selection and Characteristics}

One hundred fourteen patients ( 81 men, 33 women; mean \pm SD age, $54 \pm 9$ years) with highly symptomatic $\mathrm{AF}$ were included in this prospective study. Inclusion criteria were a history of AF $>18$ months, previously ineffective antiarrhythmic drug therapy (at least 1 antiarrhythmic drug), and at least 3 documented $\mathrm{AF}$ episodes together with corresponding symptoms. Before inclusion into the study, patients judged their overall impairment due to the arrhythmia on an ordinal scale between 0 and 10 ( 0 being no complaints at all and 10 being unbearable complaints). Most $(95 \%)$ patients with documented AF during the 7-day ECG period described their individual impairment due to the arrhythmia as medium to severe on that ordinal scale $(\geq 6)$.

\footnotetext{
Received July 8, 2004; de novo received November 3, 2004; revision received March 30, 2005; accepted March 31, 2005.

From the Heart Center, Department of Electrophysiology, University of Leipzig, Leipzig, Germany.

Correspondence to Gerhard Hindricks, MD, University of Leipzig, Heart Center, Department of Electrophysiology, Strümpellstrasse 39, 04289 Leipzig, Germany.E-mail hindg@medizin.uni-leipzig.de

(1) 2005 American Heart Association, Inc.

Circulation is available at http://www.circulationaha.org

DOI: 10.1161/CIRCULATIONAHA.104.518837
}

Downloaded from circ.ahajournals.org. 34 SWETS SUBS SERV on July 30, 2009 
Ninety-six $(84 \%)$ patients had paroxysmal AF, and $18(16 \%)$ had persistent AF. Persistent AF was defined as continuous arrhythmia throughout the 7-day Holter monitoring period before ablation. Organic heart disease was present in $21(19 \%)$ patients (coronary artery disease, $\mathrm{n}=11$; valvular heart disease, $\mathrm{n}=7$; dilated cardiomyopathy, $\mathrm{n}=3)$, and $48(42 \%)$ patients had a history of arterial hypertension. Sixty $(53 \%)$ patients had so-called "lone AF." Mean left ventricular ejection fraction was $62 \pm 8 \%$, and mean left atrial diameter measured $40 \pm 6 \mathrm{~mm}$. The median history of AF was 5 years (range, 18 months to 8 years). Prior attempts of AF ablation had been performed in $10(9 \%)$ patients, and isthmus ablation for common atrial flutter had been performed in $10(9 \%)$.

\section{ECG Monitoring and Follow-Up}

After inclusion into the study and before ablation, a continuous 7-day ECG (Lifecard CF, Delmar Reynolds Medical Inc) was recorded in all patients. The patients were equipped with a detailed symptom log and instructed on how to document duration and quality of any occurring symptoms. Complaints of palpitations, dyspnea, dizziness, and chest pain were taken as surrogates of AF. The continuous 7-day ECG was repeated immediately after ablation and after 3,6 , and 12 months of follow-up. In cases when symptoms occurred outside the recording periods, patients were advised to contact our institution or the referring physician to obtain ECG documentation. AF $>30$ seconds was considered an episode of sustained AF recurrence. Recordings of atrial flutter were analyzed separately.

A total of 114 patients were included in the study in a consecutive fashion. All patients have completed at least 3 months of follow-up. At the time of data analysis, 110 patients had completed at least 6 months of follow-up after the ablation procedure. Two patients were lost to follow-up within the first 6 months after ablation. Thus, data obtained for 108 patients were analyzed at 6 months. Of these 108 patients, $10(8.8 \%)$ with recurrences of $\mathrm{AF}$ underwent a reablation procedure, and 2 additional patients were lost to follow-up within the monitoring period from 6 months to 1 year. Seventy patients have completed 1 year of follow-up, whereas 26 patients are currently in follow-up between 6 months and 1 year. Thus, the dropout rate was low during the total course of the study. We lost 4 patients $(3.5 \%)$ during follow-up, and 10 patients $(8.8 \%)$ did not complete 1 year of follow-up because of a reablation after 6 months.

\section{Data Analysis}

More than 70000 hours of continuous ECG recording were analyzed. The physician performing the analysis was blinded with regard to patient name, date of ablation, and the patient's symptom log. After symptoms and rhythms were correlated, the 7-day ECG was divided into hours with symptomatic $\mathrm{AF}$, hours with asymptomatic $\mathrm{AF}$, hours with symptomatic sinus rhythm (SR), and hours with asymptomatic SR.

Furthermore, the single AF episode was classified as symptomatic or asymptomatic. Because of the difficulty in discriminating the symptomaticity in cases of multiple, short episodes ( $<30$ minutes) separated by only a few minutes of SR, these episodes together were considered a single episode. Finally, the patients with documented AF were divided into 3 different groups of AF perception: symp- tomatic patients only, asymptomatic patients only, and patients with a mixture of symptomatic and asymptomatic AF.

\section{Catheter Ablation Procedure}

The ablation procedure was performed as reported elsewhere in detail..$^{3,4}$ In brief, circular left atrial linear lesions were deployed in the left atrium around the ostia of the pulmonary veins by electroanatomic mapping (CARTO, Biosense Webster). Additional linear lesion lines were then deployed between the circular lesions along the roof the left atrium as well as between the circular lesion and the mitral annulus. The total procedure time was $133 \pm 33$ minutes, total fluoroscopy time was $21 \pm 11$ minutes, and RF current application time was $33 \pm 7$ minutes.

\section{Statistics}

Continuous variables are presented as mean $\pm \mathrm{SD}$, where appropriate. In cases of a nongaussian distribution, medians and quartiles are given. Categorical variables are expressed as numbers and percentages of patients.

During follow-up, the changes in the number of patients within the 3 AF perception groups as well as other categorical data, such as the number of patients taking $\beta$-blocker and antiarrhythmic drugs, were tested for any statistically significant difference with the $\chi^{2}$ test for trend. When a significant difference was found, each follow-up point was tested individually against status before ablation with the McNemar test.

Changes in continuous data during follow-up, such as total AF hours (ie, AF duration), total AF episodes, percentage of asymptomatic AF hours, percentage of asymptomatic AF episodes, mean heart rate during $\mathrm{AF}$, and mean heart rate during SR, were tested for any statistically significant difference with Friedman's test. When a significant difference was found, each follow-up point was tested individually against status before ablation by the Wilcoxon test and a Bonferroni correction. Additionally, the change in the percentage of asymptomatic AF hours and the percentage of asymptomatic AF episodes throughout follow-up was analyzed with the $\chi^{2}$ test for trend in binomial proportions (the 2 groups consisting of patients either with or without an increase of asymptomatic AF hours or AF episodes).

To compare the characteristics of patients within the 3 different AF perception groups, continuous data such as age, duration of AF history, AF burden (episodes and hours), mean heart rate during $\mathrm{AF}$, mean heart rate during SR, and echocardiographic parameters were tested for any statistically significant difference with a 1-way ANOVA for normally distributed data and the Kruskal-Wallis test for data in a nongaussian distribution. Differences in categorical data, such as sex, presence of structural heart disease, previous ablation attempts, and use of $\beta$-blocker and antiarrhythmic drugs, were tested for statistical significance among each of the 3 perception groups with the $\chi^{2}$ test. A probability value $<0.05$ was considered statistically significant.

\section{Results}

Rhythm Analysis

The results are shown in Table 1. During the entire course of the study, the percentage of patients with asymptomatic AF

TABLE 1. Rhythm Outcome and Perception of AF Before and After RF Ablation

\begin{tabular}{|c|c|c|c|c|c|c|}
\hline & \multirow[b]{2}{*}{$\mathrm{n}$} & \multirow[b]{2}{*}{ Patients With SR, n } & \multicolumn{4}{|c|}{ Patients With AF } \\
\hline & & & $\mathrm{n}$ & $\begin{array}{l}\text { Asymptomatic } \\
\text { Patients Only }\end{array}$ & $\begin{array}{l}\text { Symptomatic } \\
\text { Patients Only }\end{array}$ & $\begin{array}{c}\text { Symptomatic }+ \text { Asymptomatic } \\
\text { Patients }\end{array}$ \\
\hline Before ablation & 114 & $22(19 \%)$ & 92 & $5(5 \%)$ & $35(38 \%)$ & $52(57 \%)$ \\
\hline \multicolumn{7}{|l|}{ After ablation } \\
\hline Immediately & 114 & $36(32 \%) P=0.12$ & 78 & $17(22 \%) P=0.027$ & $16(21 \%) P=0.002$ & $45(57 \%) P=0.48$ \\
\hline 3 Months & 114 & $65(57 \%) P=0.001$ & 49 & $18(38 \%) P=0.021$ & $8(16 \%) P=0.001$ & $23(46 \%) P=0.001$ \\
\hline 6 Months & 108 & $54(50 \%) P=0.001$ & 54 & $20(37 \%) P=0.021$ & $14(26 \%) P=0.078$ & $20(37 \%) P=0.001$ \\
\hline 12 Months & 70 & $45(64 \%) P=0.021$ & 25 & $9(36 \%) P=0.05$ & $5(20 \%) P=0.07$ & $11(44 \%) P=0.001$ \\
\hline
\end{tabular}

Downloaded from circ.ahajournals.org at SWETS SUBS SERV on July 30, 2009 

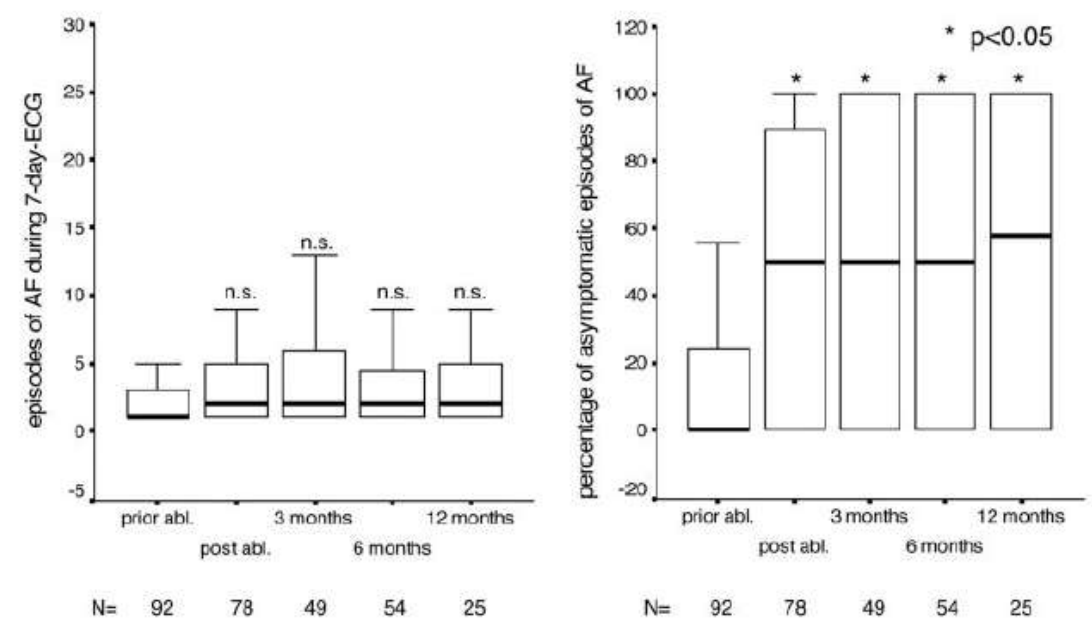
Figure 1. Left, Box-and-whisker plot showing number of AF episodes rec- orded during 7-day Holter ECG monitor- ing in patients with documented AF occurrences before and after RF ablation (abl.). Medians, quartiles, and extreme values are given. Right, Box-and-whisker plot showing percentage of asymptomat- ic $\mathrm{AF}$ epsiodes among all documented AF episodes. Medians, quartiles, and extreme values are given. Change in number of $\mathrm{AF}$ episodes during follow- up $(P=0.34)$ and increase in percentage of asymptomatic episodes $(P=0.04)$ were tested for any significant difference with Friedman's test. In post hoc analysis, each follow-up point was tested against before ablation by Wilcoxon's test and Bonferroni correction. ${ }^{*} P<0.05$.

only in all patients with documented AF recurrences significantly increased from 5\% at baseline to $22 \%$ after ablation $(P=0.027)$, to $38 \%$ at 3 -month follow-up $(P=0.021), 37 \%$ at 6-month follow-up $(P=0.021)$, and $36 \%$ at 12 -month follow-up $(P=0.05)$.

\section{Change in AF Characteristics}

During the 7-day ECG periods, patients with AF showed a median of $1(1,3) \mathrm{AF}$ episodes before ablation compared with $2(1,5)$ AF episodes immediately after ablation $(P=0.1), 2(1,6)$ after 3 months $(P=0.07), 2(1,4)$ after 6 months $(P=0.16)$, and $2(1,5)$ after 12 months $(P=0.11)$ (Figure 1$)$. The median percentage of asymptomatic AF episodes increased from $0 \%(0 \%, 25 \%)$ before ablation to $50 \%(0 \%, 89 \%)$ immediately after ablation ( $P=0.001), 50 \%(0 \%, 100 \%)$ after 3 months $(P=0.004)$, $50 \%(0 \%, 100 \%)$ after 6 months $(P=0.017)$, and $58 \%(0 \%, 100 \%)$ after 12 months $(P=0.04)$ (Figure 1).

For patients with documented AF, the median total arrhythmia duration during the 7-day ECG periods measured 38 (10, 133 ) hours before ablation and postinterventionally declined to $36(22,79)$ hours immediately after ablation $(P=0.21), 23$ $(8,41)$ hours after 3 months $(P=0.023), 17(8,43)$ hours after 6 months $(P=0.038)$, and $10(3,25)$ hours after 12 months $(P=0.013)$ (Figure 2$)$. The percentage of asymptomatic AF among the total arrhythmia duration showed a trend to increase nonsignificantly, from $62 \%(6 \%, 88 \%)$ before ablation, $70 \%(10 \%, 98 \%)$ immediately after ablation $(P=0.13)$, $73 \%(23 \%, 96 \%)$ after 3 months $(P=0.18), 77 \%(8 \%, 100 \%)$ after 6 months $(P=0.15)$, and $77 \%(34 \%, 88 \%)$ after 12 months $(P=0.85)$ (Figure 2).

The observed decrease in total AF duration after RF ablation resulted in a marked change in the AF distribution/ variability pattern during the 7 -day recording periods. Figure 3 illustrates the percentage of patients with documented AF during 1 to 7 days of the Holter recording period. Before ablation, $40 \%$ of patients with AF showed arrhythmias during a single day of the 7-day period only. Twelve months after ablation, $74 \%$ of patients with recurrences showed AF during a single day of the 7-day period only, and furthermore, none of the patients with AF recurrences had an arrhythmia on $>3$ days of the 7-day period (Figure 3).

\section{Role of $\beta$-Blocker and Antiarrhythmic Drugs}

As part of our study protocol, after ablation, the patients received a $\beta$-blocker and an antiarrhythmic drug (flecainide or amiodarone) for at least 3 months, if tolerated. Afterward, the medication was adapted on an individual basis. Table 2
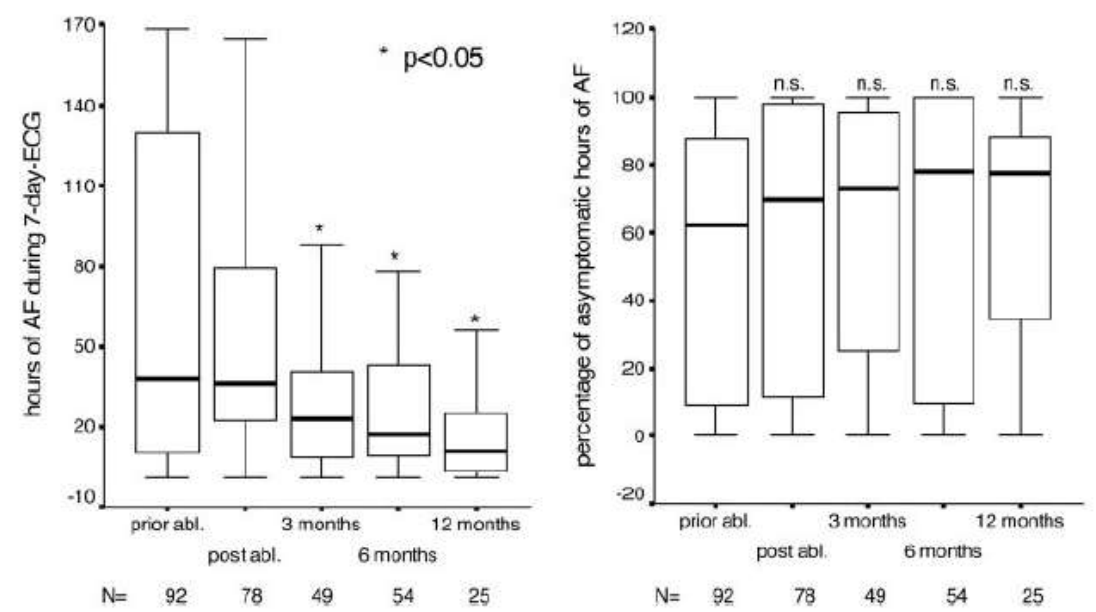

Figure 2. Left, Box-and-whisker plot showing hours of AF (ie, total AF duration) recorded during 7-day Holter ECG monitoring in patients with documented $\mathrm{AF}$ occurrences before and after RF ablation (abl.). Medians, quartiles, and extreme values are given. Right, Boxand-whisker plot showing percentage of asymptomatic hours among all documented AF hours. Medians, quartiles, and extreme values are given. Decrease in total AF duration after ablation $(P=0.001)$ and change in percentage of asymptomatic hours $(P=0.07)$ were tested for any significant difference with Friedman's test. In post hoc analysis, each follow-up point was tested against before ablation with Wilcoxon's test and Bonferroni correction. ${ }^{\star} P<0.05$.

Downloaded from circ.ahajournals.org at SWETS SUBS SERV on July 30, 2009 

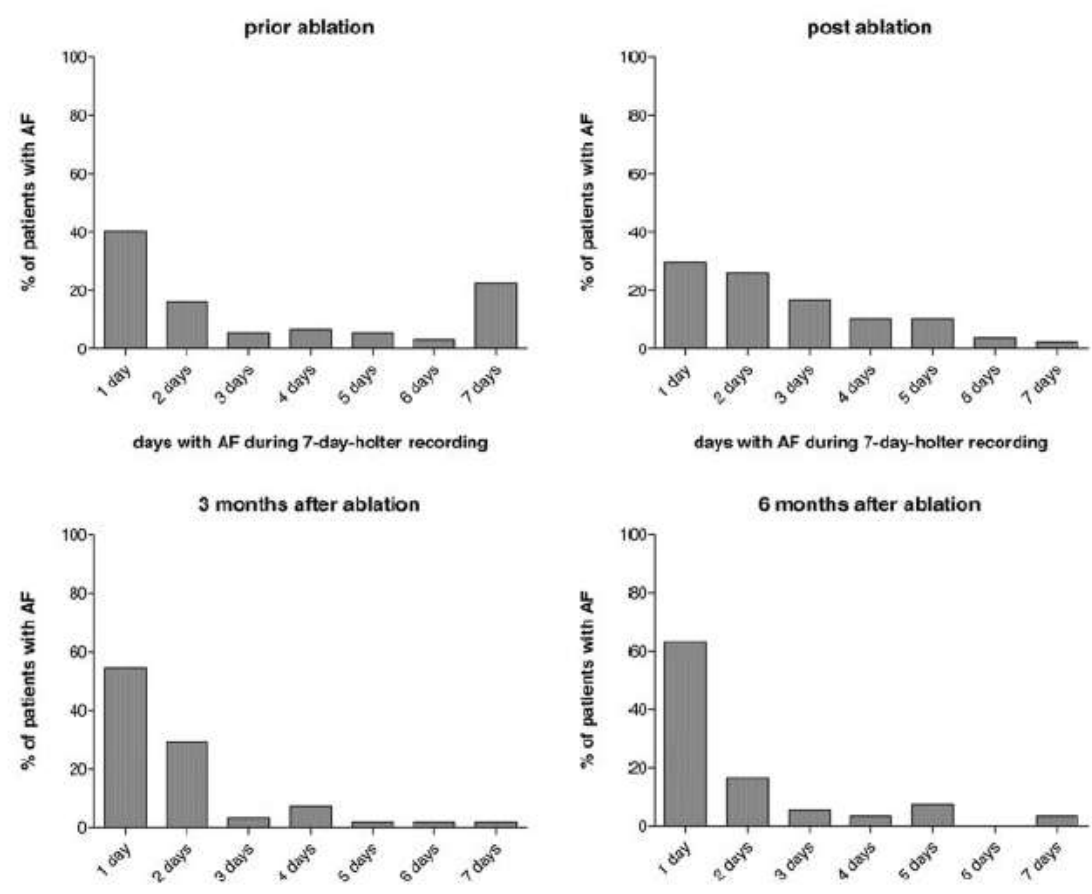

Figure 3. Bar graphs illustrating AF distribution/variability during 7-day ECG recording period. At each follow-up point, patients with arrhythmia were classified according to number of days with documented $\mathrm{AF}$ ( 1 to 7 days). Number of patients in each of 7 groups is given as percentage of all patients with documented AF recurrences.

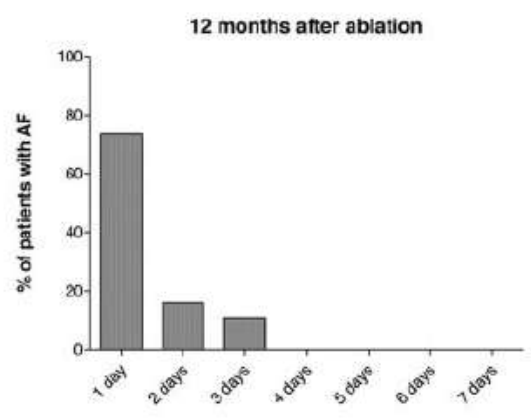

days with AF during 7-day-holter recording

summarizes the medications for patients with documented AF recurrences during follow-up. Because of the study protocol, the percentage of patients taking $\beta$-blockers increased from $57 \%$ before ablation to $77 \%$ after ablation, $86 \%$ after 3 months, $70 \%$ after 6 months, and $72 \%$ after 12 months. The increase after ablation $(P=0.013)$ and after 3 months $(P=0.012)$ was statistically significant (Table 2$)$.
The use of class Ic antiarrhythmic drugs significantly decreased after the 3 -month follow-up, from $51 \%$ before ablation to $24 \%$ after 12 months $(P=0.001)$. The percentage of patients taking class III antiarrhythmic drugs steadily declined from $41 \%$ before ablation to $16 \%$ after 12 months $(P=0.001)$ (Table 2).

Comparing the intake of $\beta$-blockers and/or antiarrhythmic drugs among the 3 different AF-perception groups did not

TABLE 2. Use of $\beta$-Blockers and Antiarrhythmic Drugs, Mean Heart Rate During AF, and Mean Heart Rate During SR in Patients With AF

\begin{tabular}{lccccc}
\hline & Before Ablation & After Ablation & 3 Months & 6 Months & 12 Months \\
\hline No. & 114 & 114 & 114 & 108 & 70 \\
No. of patients with AF & $92(81 \%)$ & $78(68 \%)$ & $49(43 \%)$ & $54(50 \%)$ & $25(36 \%)$ \\
$\beta$-Blockers & $57 \%$ & $77 \% P=0.013$ & $86 \% P=0.012$ & $70 \% P=0.14$ & $72 \% P=0.1$ \\
Class IC antiarrhythmics & $51 \%$ & $58 \% P=0.16$ & $51 \% P=0.51$ & $35 \% P=0.014$ & $24 \% P=0.001$ \\
Class III antiarrhythmics & $41 \%$ & $23 \% P=0.002$ & $30 \% P=0.08$ & $16 \% P=0.001$ & $16 \% P=0.001$ \\
AF-HR (25th, 75th percentile) & $110(95,120)$ & $100(90,120) P=0.08$ & $100(91,120) P=0.64$ & $110(90,120) P=0.73$ & $110(90,130) P=0.45$ \\
SR-HR (25th, 75th percentille) & $66(60,75)$ & $66(60,72) P=0.99$ & $65(60,72) P=0.52$ & $65(56,74) P=0.43$ & $70(59,74) P=0.99$ \\
\hline
\end{tabular}

HR indicates heart rate. 
TABLE 3. Occurrence and Perception of Atrial Flutter Before and After Ablation

\begin{tabular}{lccccc}
\hline & & \multicolumn{5}{c}{ Patients With Atrial Flutter } \\
\cline { 3 - 6 } & & All & $\begin{array}{c}\text { Symptomatic } \\
\text { Patients } \\
\text { Only }\end{array}$ & $\begin{array}{c}\text { Asymptomatic } \\
\text { Patients } \\
\text { Only }\end{array}$ & $\begin{array}{c}\text { Symptomatic+ } \\
\text { Asymptomatic } \\
\text { Patients }\end{array}$ \\
\hline $\begin{array}{l}\text { Before ablation } \\
\text { After ablation }\end{array}$ & 114 & $9(7.8 \%)$ & 2 & 1 & 6 \\
$\quad$ Immediately & 114 & $14(12.3 \%)$ & 2 & 3 & 9 \\
3 Months & 114 & $8(7.1 \%)$ & $\ldots$ & 1 & 7 \\
6 Months & 108 & $6(5.5 \%)$ & $\ldots$ & 2 & 4 \\
12 Months & 70 & $1(1.4 \%)$ & $\ldots$ & - & 1 \\
\hline
\end{tabular}

show a significant difference at any time before or after ablation.

\section{Role of Heart Rate During AF}

Table 2 displays the mean heart rate during AF after RF ablation among all patients with documented arrhythmia recurrences. Medians and quartiles are given. Despite the postinterventional increase in asymptomatic AF and at least a temporary increase in $\beta$-blocker medication, the mean heart rate during the arrhythmia did not change significantly $(110 \mathrm{bpm}$ before ablation, $100 \mathrm{bpm}$ after ablation, and 100,110 , and 110 bpm after 3, 6, and 12 months, respectively [Table 2]).

Furthermore, the mean heart rate during AF was compared among patients with different AF perception (symptomatic patients only, asymptomatic patients only, and symptomatic+asymptomatic patients) at each follow-up point before and after RF ablation. Corresponding to the comparable usage of $\beta$-blocker and antiarrhythmic medications among these 3 groups, mean heart rate during $\mathrm{AF}$ was not significantly different at any follow-up point.

\section{Role of Patient Characteristics}

To analyze other parameters possibly influencing arrhythmia perception, characteristics of patients with different AF perception (symptomatic patients only, asymptomatic patients only, symptomatic+asymptomatic patients) were compared among these 3 groups. No statistically significant differences with respect to age, sex, left ventricular ejection fraction, left atrial size, left atrial appendage flow velocity, and duration of AF history were found. The majority of patients in all 3 groups experienced paroxysmal $\mathrm{AF}$ ( $91 \%$ versus $80 \%$ versus $81 \%, P=0.21$ ) and had no structural heart disease $(91 \%$ versus $100 \%$ versus $82 \%, P=0.12$ ). In all 3 groups, previous AF catheter ablation had been similar $(12 \%$ versus $20 \%$ versus $15 \%, P=0.15$ ). Though statistically not significant, in patients with asymptomatic AF a tendency toward a longer AF duration during the 7-day ECG period before ablation was observed ( 19 versus 39 versus 31 hours, $P=0.07$ ). A possible influence of socioeconomic factors on the perception of $\mathrm{AF}$ was studied by analyzing the percentage of university graduates in all 3 groups. However, no significant difference could be found. In summary, none of the studied parameters was significantly different and thereby predictive for the perception of $\mathrm{AF}$.
Occurrence and Perception of Atrial Flutter

The number of patients with documented atrial flutter during the 7-day ECG periods was $9(7.8 \%)$ patients before ablation, $14(12.3 \%)$ immediately after ablation, and $8(7.1 \%), 6$ $(5.5 \%)$, and $1(1.4 \%)$ patients after 3,6 , and 12 months, respectively (Table 3 ). All patients with atrial flutter showed episodes of AF on the same 7-day ECG as well.

Throughout the study, only $2(1.7 \%)$ patients before ablation and 2 patients $(1.7 \%)$ immediately after ablation recognized every episode of atrial flutter. At 3, 6, and 12 months' follow-up, the arrhythmia was always at least partially asymptomatic (Table 3). A comparison of the mean heart rate between symptomatic and asymptomatic episodes of atrial flutter revealed a significant difference, with asymptomatic episodes showing a lower mean heart rate (125 versus 95 bpm, $P=0.04$ ) (Figure 4). These results indicate that in cases of a near to normal ventricular rate, recurrences of atypical

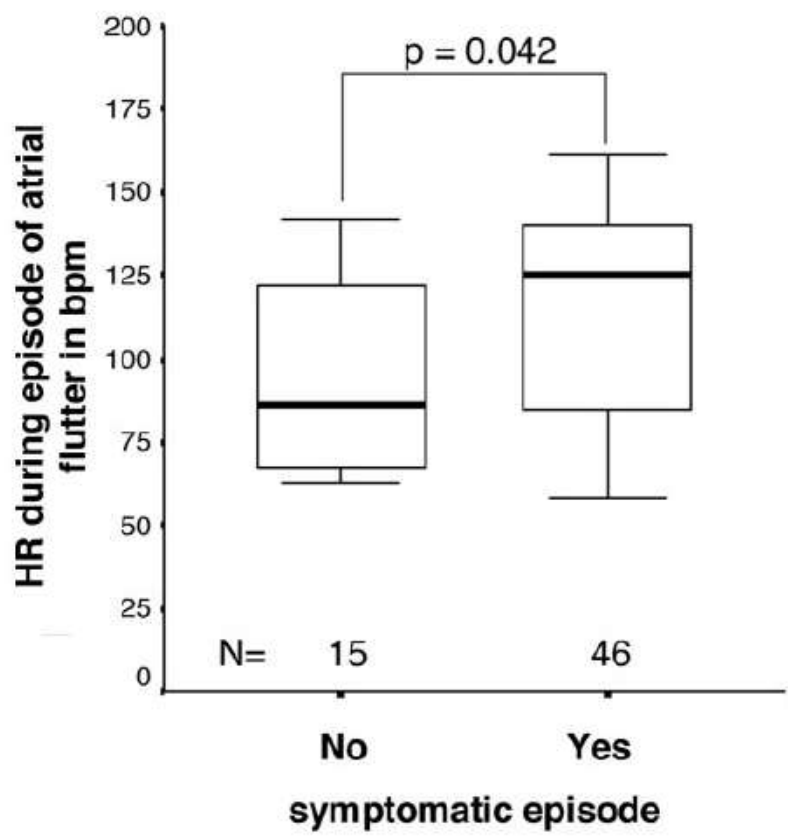

Figure 4. Box-and-whisker plot comparing heart rate of symptomatic and asymptomatic episodes of atrial flutter recorded during 7-day Holter ECG monitoring. Medians, quartiles, and extreme values are given. Difference between both groups was tested for significance by Mann-Whitney $U$ test. ${ }^{*} P<0.05$. 
atrial flutter after an AF ablation procedure could be more asymptomatic than $\mathrm{AF}$ recurrences themselves. However, the limited number of patients with atrial flutter at each follow-up point precluded a more detailed analysis of arrhythmia pattern and patient characteristics influencing arrhythmia perception.

\section{Discussion}

\section{Main Findings of the Study}

The results of this study show that asymptomatic AF can occur in patients presenting with highly symptomatic AF who qualify for catheter ablation. Before ablation, $>50 \%$ of patients showed a mixture of symptomatic and asymptomatic $\mathrm{AF}$, whereas only $38 \%$ of patients recognized all AF episodes accurately. Moreover, $5 \%$ of patients had only asymptomatic AF during the initial 7-day ECG period, despite previously documented symptomatic AF episodes. After catheter ablation, the incidence of asymptomatic AF significantly increased: At 3, 6, and 12 months' follow-up, 38\%, 37\%, and $36 \%$ of patients with arrhythmia recurrence were completely asymptomatic. These findings may have important implications for strategy and the intensity of follow-up after catheter ablation procedures.

\section{Perception of AF Before Catheter Ablation}

Patients selected for AF catheter ablation represent a highly symptomatic subgroup within the total AF population. However, the detailed arrhythmia characteristics of these patients with respect to symptomatic and asymptomatic AF episodes have not been described before. In the present study, $>95 \%$ of patients with documented AF during the 7-day Holter period before ablation showed symptomatic AF episodes, characterizing a population of truly highly symptomatic individuals. On the other hand, $>50 \%$ of them also had asymptomatic episodes, a surprisingly high number. For a similar patient cohort, no comparable data are available in the literature. It may be argued that our patient population was not representative of $\mathrm{AF}$ patients selected for catheter ablation in general. However, by comparing the patient characteristics in this analysis with data from other studies on AF catheter ablation, no striking differences could be found. ${ }^{4-6}$

\section{Perception of AF After Catheter Ablation}

The significant increase in patients with asymptomatic AF only after the ablation procedure may be discussed in different ways. First, the percentage of patients taking $\beta$-blockers significantly increased after ablation because of our study protocol, which recommends $\beta$-blockers to all patients undergoing the procedure. ${ }^{3}$ That increase in $\beta$-blocker use may explain the increase in asymptomatic-only patients directly after ablation. However, during further follow-up, the percentage of patients taking $\beta$-blockers remained stable, and the percentage of patients taking antiarrhythmic drugs significantly decreased. Thus, despite a reduction in antiarrhythmic drug use, the percentage of completely asymptomatic patients increased, making a causal relation between drugs and symptoms in our patient population unlikely. Moreover, the mean heart rate during AF was not significantly different between symptomatic and asymptomatic patients.
Invasive treatment of AF per se may result in changes of arrhythmia perception caused by (1) a placebo effect, (2) an ablation-induced change in arrhythmia pattern, or (3) an ablation-induced modulation of the autonomic nervous system. In nonrandomized and nonblinded studies such as the present one, the impact of the placebo effect on the perception of $\mathrm{AF}$ is difficult to estimate. From other invasive procedures such as percutaneous myocardial laser revascularization, it is well known that simply the fact of an invasive procedure being performed significantly alters the perception of preexisting symptoms. ${ }^{7}$ The same may also be true after catheter ablation of AF. Gerstenfeld et $\mathrm{al}^{8}$ and Berkowitsch et $\mathrm{al}^{9}$ reported an improved quality of life despite AF recurrences after pulmonary vein disconnection procedures, which supports that hypothesis. Circumferential pulmonary vein ablation may change the arrhythmia pattern and characteristics. Details about rhythm outcome and changes in arrhythmia pattern observed in our patients are presented elsewhere. ${ }^{3}$ As a general pattern, in cases of postinterventional arrhythmia recurrences, the number of $\mathrm{AF}$ episodes was unchanged, but the duration of single episodes decreased. However, comparing the arrhythmia pattern (AF duration, number of $\mathrm{AF}$ episodes, mean heart rate) in patients with and without symptoms did not reveal any significant difference, not even a trend. Thus, as observed in other studies of asymptomatic $\mathrm{AF}$, it is impossible to define a subset of patients who might be preserved from asymptomatic arrhythmias. ${ }^{1,2}$ Furthermore, results of the present study as well as previously published data show that a history of symptomatic $\mathrm{AF}$ does not guarantee only symptomatic recurrences in the future. ${ }^{10,11}$ Eventually, the effects of circumferential pulmonary vein ablation on the autonomic nervous system of the heart, though currently not completely understood, may have an impact on the perception of AF after ablation. ${ }^{12}$ Further studies are needed to clarify this issue.

In a recent study, Oral et al ${ }^{13}$ described the prevalence of symptomatic and asymptomatic AF after an apparently successful segmental pulmonary vein disconnection procedure in 60 of 244 consecutive patients. For 30 days, they were provided with a patient-activated transtelephonic event recorder $642 \pm 195$ days after the ablation procedure. All 60 patients had not had an episode of symptomatic $\mathrm{AF}$ at $\geq 6$ months after the ablation procedure until participating in that follow-up study. AF was documented in 8 of 60 patients (13\%) and was symptomatic in 7 patients but asymptomatic in only 1 . The authors concluded that asymptomatic AF episodes are infrequent after apparently successful catheter ablation procedures. The data presented by Oral et al may be interpreted as inconsistent with the findings of our study. However, this may at least in part be due to significant differences in study protocols. The most important differences include patient selection (voluntary subset of 60 of 244 patients selected almost 2 years after ablation versus 114 consecutive patients prospectively included in our study), ablation strategy (segmental pulmonary vein disconnection versus circumferential left atrial ablation in our study), the time frame of follow-up (almost 2 years after ablation versus the first 12 months after ablation in our study), as well as the rhythm monitoring strategy (event recorders versus continu- 
ous long-term Holter recordings). When comparing the results of the study by Oral et al with our data, the important methodological limitations of their study must be considered, which have also been addressed in detail in an editorial published along with their article. ${ }^{14}$ One interesting and unanswered question about the data from Oral et al relates to the fact that $12 \%$ of patients who were completely free of symptomatic AF recurrences from 6 months to almost 2 years after the ablation procedure suddenly developed symptomatic AF recurrences within a mean of only 25 days of follow-up after having been equipped with an event recorder. One possible explanation may be that the patients did have asymptomatic AF after the ablation procedure and were simply sensitized to arrhythmia-related symptoms by participating in a scientific study. However, this is only speculative. Overall, the discrepant results obtained in both studies underline the need for additional detailed studies to further clarify the relevance of asymptomatic AF recurrences after catheter ablation procedures. ${ }^{14}$

\section{Study Limitations}

Possible limitations of the present study are related to the high percentage of patients taking $\beta$-blocker and antiarrhythmic drugs after ablation (discussed earlier in detail). Therefore, it cannot be excluded that more restrictive use of these drugs might have resulted in a lower incidence of asymptomatic $\mathrm{AF}$.

\section{Clinical Implications}

The results of our study show that asymptomatic AF frequently occurs in highly symptomatic patients before and after RF catheter ablation. As a consequence, close and objective follow-up strategies with repetitive, long-term, Holter monitoring devices are necessary to analyze rhythm outcome after these procedures. Moreover, our data show that a symptom-only-based follow-up could substantially overestimate the success rate of the ablation procedure. In that sense, our analysis may help explain the inconsistent data on the success rates of AF catheter ablation reported in the literature. For the individual patient, the most significant implication of asymptomatic AF is related to the need for oral anticoagulation after the ablation procedure. Thus, withdrawal of oral anticoagulation after ablation should be considered carefully, based on reliable and objective measures such as long-term Holter records rather than symptoms.

\section{References}

1. Savelieva I, Camm AJ. Clinical relevance of silent atrial fibrillation: prevalence, prognosis, quality of life, and management. $J$ Interven Cardiac Electrphysiol. 2000;4:369-382.

2. Israel CW, Gronefeld G, Ehrlich JR, Li YG, Hohnloser SH. Long-term risk of recurrent atrial fibrillation as documented by an implantable monitor device. J Am Coll Cardiol. 2004;43:47-52.

3. Kottkamp H, Tanner H, Kobza R, Schirdewahn P, Dorszewski A, Gerds-Li JH, Carbucicchio C, Piorkowski C, Hindricks G. Time course and quantitative analysis of atrial fibrillation episode number and duration after circular plus linear left atrial ablation: trigger elimination or substrate modification, early or delayed cure? J Am Coll Cardiol. 2004;44: $869-877$.

4. Oral H, Scharf C, Chugh A, Hall B, Cheung P, Good E, Veerareddy S, Pelosi F Jr, Morady F. Catheter ablation for paroxysmal atrial fibrillation: segmental pulmonary vein ostial ablation versus left atrial ablation. Circulation. 2003;108:2355-2360.

5. Pappone C, Rosanio S, Augello G, Gallus G, Vicedomini G, Mazzone P, Gulletta S, Gugliotta F, Pappone A, Santinelli V, Tortoriello V, Sala S, Zangrillo A, Crescenzi G, Benussi S, Alfieri O. Mortality, morbidity, and quality of life after circumferential pulmonary vein ablation for atrial fibrillation: outcomes from a controlled nonrandomized long-term study. J Am Coll Cardiol. 2003;42:185-187.

6. Haissaguerre M, Jais P, Shah DC, Takahashi A, Hocini M, Quiniou G. Garrigue S, Le Mouroux A, Le Metayer P, Clementy J. Spontaneous initiation of atrial fibrillation by ectopic beats originating from the pulmonary veins. $N$ Engl $J$ Med. 1998;339:659-666.

7. Saririan M, Eisenberg MJ. Myocardial laser revascularisation for the treatment of end-stage coronary artery disease. J Am Coll Cardiol. 2003; 41:173-183.

8. Gerstenfeld EP, Guerra P, Sparks PB, Hattori K, Lesh MD. Clinical outcome after radiofrequency catheter ablation of focal atrial fibrillation triggers. J Cardiovasc Electrophysiol. 2001;12:900-908.

9. Berkowitsch A, Neumann T, Kurzidim K, Reiner C, Kuniss M, Siemon G, Sperzel J, Pitschner HF. Comparison of generic health survey SF-36 and arrhythmia related symptom severity check list in relation to postablation recurrence. Europace. 2003;5:351-355.

10. Page RL, Wilkinson WE, Clair WK, McCarthy EA, Pritchett EL. Asymptomatic arrhythmias in patients with symptomatic paroxysmal atrial fibrillation and paroxysmal supraventricular tachycardia. Circulation. 1994; 89:224-227.

11. Page RL, Tilsch TW, Connolly SJ, Schnell DJ, Marcello SR, Wilkinson WE, Pritchett EL. Azimilide Supraventricular Arrhythmia Program (ASAP) Investigators. Asymptomatic or silent atrial fibrillation: frequency in untreated patients and patients receiving azimilide. Circulation. 2003;107:1141-1145.

12. Pappone C, Santinelli V, Manguso F, Vicedomini G, Gugliotta F, Augello G, Mazzone P, Tortoriello V, Landoni G, Zangrillo A, Lang C, Tomita T, Mesas C, Mastella E, Alfieri O. Pulmonary vein denervation enhances long-term benefit after circumferential ablation for paroxysmal atrial fibrillation. Circulation. 2004;109:327-334.

13. Oral H, Veerareddy S, Good E, Hall B, Cheung P, Tamirisa K, Han J, Fortino J, Chugh A, Bogun F, Pelosi F Jr, Morady F. Prevalence of asymptomatic recurrences of atrial fibrillation after successful radiofrequency catheter ablation. J Cardiovascular Electrophysiol. 2004;15: 920-924.

14. Callans D. Asymptomatic atrial fibrillation in symptomatic patients. J Cardiovasc Electrophysiol. 2004;15:925-926. 
4.4. Einfluss der Vorhofflimmerperzeption auf das Monitoring nach Ablation

4.4.2. Einfluss der Dauer der Langzeit-EKG-Aufzeichnung auf die Detektion von Arrhythmierezidiven nach Katheterablation von Vorhofflimmern: Implikationen für die Nachkontrolle der Patienten

Zitierweise:

Nikolaos Dagres, Hans Kottkamp, Christopher Piorkowski, Sebastian Weis, Arash Arya, Philipp Sommer, Kerstin Bode, Jin-Hong Gerds-Li, Dimitrios Th. Kremastinos, Gerhard Hindricks.

Influence of the duration of Holter monitoring on the detection of arrhythmia recurrences after catheter ablation of atrial fibrillation: Implications for patient followup.

Int J Cardiol, October 2008, [Epub ahead of print]. 


\title{
Influence of the duration of Holter monitoring on the detection of arrhythmia recurrences after catheter ablation of atrial fibrillation Implications for patient follow-up
}

\author{
Nikolaos Dagres ${ }^{a, *}$, Hans Kottkamp ${ }^{c}$, Christopher Piorkowski ${ }^{b}$, Sebastian Weis ${ }^{b}$, Arash Arya ${ }^{b}$, \\ Philipp Sommer ${ }^{b}$, Kerstin Bode ${ }^{b}$, Jin-Hong Gerds-Li ${ }^{b}$, \\ Dimitrios Th. Kremastinos ${ }^{a}$, Gerhard Hindricks ${ }^{b}$ \\ "Universin of Arhens, Second Canfiology Deparmment, Atrikon Univensiny Hospial, Athenx, Greece \\ " Universiy of Leipsig. Hearr Cente, Department of Electrophysiology, Leipsig Germany \\ "Heart Center Hirslanden. Depariment of Electrophysiology. Zurich, Switzerland
}

Received I May 2008; accepced 1 October 2008

\begin{abstract}
We investigated the influence of Holter duration on the detection of recurrences after ablation for atrial fibrillation (AF). Two-hundredand-fifteen patients underwent a 7-day Holter ECG at 6 months after catheter ablation. We analyzed the number of patients who had a recurrence within the first $24,48,72 \mathrm{~h}$ etc. up to the total of 7 days. During the complete 7 -day recording, $30 \%$ had a recurrence. All Holter durations $\leq 5$ days would bave detected significantly less patients with recurrence than the complete 7-day reoording. A 24-bour Holter would have detected $59 \%$, a 48 -hour Holter $67 \%$ and a 72 -hour Hotter $80 \%$ of patients with recurrences, whereas a 4 -day reconding would have detected $91 \%$ of the recurrenoes that were detected with the complete 7-day reconding. In conclusion, a Holter duration of less than 4 days misses a great portion of recurrences, whereas a 4-day recording might offer a reasonable compromise.

O 2008 Elsevier Ireland Lid. All rights reserved.
\end{abstract}

Accurate detection of recurrences after catheter ablation for atrial fibrillation (AF) is crucial for patient management and hindered by the high number of asymptomatic AF episodes [1]. Several forms of rhythm monitoring are applied, such as Holter recording of variable duration, transtelephonic monitoring, or event monitors [2]. We compared the yield of different Holter durations from 1 to 7 days for the detection of recurrences after AF ablation.

We studied 215 consecutive patients ( 159 men; age $56 \pm$ 10 years) undergoing a 7-day Holter ECG at 6 months after AF ablation. Ninety-four percent had paroxysmal AF, the remaining had persistent $\mathrm{AF}$, defined as continuous anhythmia

\footnotetext{
- Corresponding author. Tel: $+302105832350 ;$ fax: +302105832351 .

$E$-mail adíress: niloolaosdaures fá yahoo,de (N. Dagres)
}

throughout a 7-day Holter before ablation. Preablation AF burden, defined as percentage of time in $\mathrm{AF}$ at the 7-day Holter before the procedure, was $32 \pm 40 \%$ (median $12 \%$ ). Circumferential pulmonary vein catheter ablation was performed as described previously [3].

Any arrhythmia with the ECG characteristics of AF, atrial flutter or atrial tachycardia lasting longer than $30 \mathrm{~s}$ was reported as arthythmia recurrence. The numbers of patients with recurrence during the first $24,48,72 \mathrm{~h}$ etc. of the Holter recording at 6 months were tested against the total number of patients who had a recurrence during the complete 7-day recording with the McNemar test with SigmaStat 3.11 (Systat Software). A $p<0.05$ was considered significant.

During the complete 7-day recording at 6 months, 64 patients $(30 \%)$ showed an arrhythmia recurrence (Fig 1). The

$0167.5273 / \$$ - see front matter 02008 Blsevier lreland Ltd. All rights reserved. doit $10.1016 /$ jijeard. $2008.10,004$ 


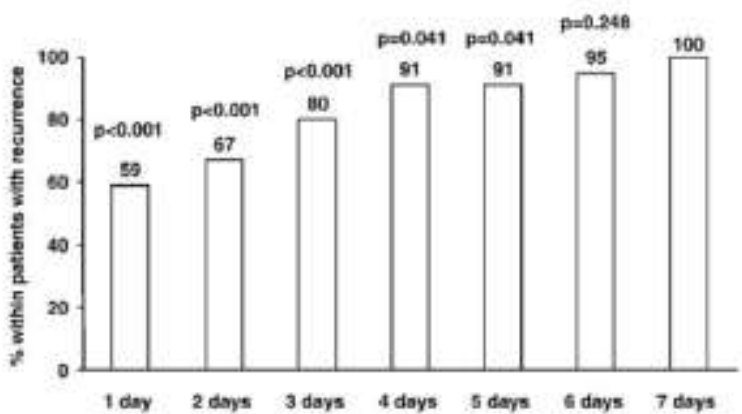

Fig. 1. Percentages of patients with recurrence within the firs $24,48,72 \mathrm{~h}$ etc. of the recorting up to the tokal dumtion of 7 days. Data are shown as percentages among the 64 patients who had a recurrence during the 7-diry Holtet. The p-values refer to the companisons with the total mumber of patients with meurrence during the complete 7-dry period.

figure depicts the percentages of patients with recurrence that would have been detected with a Holter duration of 1 day, 2 days, 3 days etc, i.e, the percentages of patients who had an arrhythmia recurrence within the first $24,48,72 \mathrm{~h}$ etc. of the recording up to the total duration of 7 days. The Figure shows these data as percentages among the 64 patients who had a recurrence during the complete 7-day period. All Holter durations up to 5 days would have detected significantly less patients with recurrence compared with the complete 7-day period: a 24-hour Holter would have detected $59 \%$ a 48 -hour Holter $67 \%$ and a 72 -hour Holter $80 \%$ of patients with recurrence. In contrast, a 4-day Holter would have already detected the great majority $(91 \%)$ of recurrences that were detected with the 7-day recording. Although a monitoring longer than 4 days still had an impact on the detection rate, the contribution was minor.

The main result of the study is that Holter monitoring with duration of less than 4 days misses a great portion of recurrences and seems to be insufficient after AF ablation.

Asymptomatic recurrences affer ablation are frequent [1]. Their detection affects decisions on anticoagulation, antiarrhythmic treatment or repeat procedures. With more extensive monitoring, more recurrences are detected [2] but workload increases and compliance diminishes. Previous studies have demonstrated that 24-hour Holter misses a large number of recurrences [3]. Our data further show that 48 -hour and 72 hour ECG recordings are also insufficient, since they would allow one third and one fifth, respectively, of recurrences to remain undetected. In contrast, a 4 -day recording detected $91 \%$ of all recurrences that were detected with the complete 7-day recording.

We used 7-day Holter at a specific time (6 months) after ablation as reference. However, even such long durations of continuous ECG recording may miss AF episodes, since AF often occurs sporadically and unpredictably. We also did not address the question how often and when Holter recordings should be repeated. Future studies utilizing implantable loop recorders could provide answers to these questions.

In conclusion, Holter monitoring with duration of less than 4 days misses a great portion of arrhythmia recurrences and seems to be insufficient after AF ablation. A 24-hour Holter would detect only $59 \%$, a 48 -hour Holter $67 \%$ of patients with recurrence and even a 72 -hour monitoring would miss $20 \%$ of the recurrences that would be detected with a 7-day recording. Instead, a 4-day recording might offer a reasonable compromise detecting $>90 \%$ of the recurrences that would be detected with a 7-day Holter

\section{References}

[1] Hindricks G, Piorkowski C, Tanner H, Kobza R, Gends-Li JH, Carbuciochio $\mathrm{C}$, a al. Pareption of atrial fitorilition before and after radisfrequency catheter ablation. Relevance of asymptomatic anthythmia recuntence. Circulation 2005;112:307-13.

[2] Arya A, Piorkowski C, Sornmer P, Kottkamp H, Hindricks G. Clinical implications of various follow up strategies after catheter ablation of itrial fikrillation. PACE 2007;30:458-62.

[3] Kotkamp H, Tanner H, Kobza R, Schirtewahn P, Dorszewski A, Gents-Li $\mathrm{HH}$, et al. Time courses and quantitative anahysis of atrial fibrillation episode tumber and duration after circular plus linear left atrial lesions trigger elmination of substrate modification: early or delayed curc? 3 Am Coll Cantiol 2004:44869-77. 
4.4. Einfluss der Vorhofflimmerperzeption auf das Monitoring nach Ablation

4.4.3. Wertigkeit verschiedener Monitoring-Strategien zur Bestimmung der Effektivität der zirkumferentiellen Pulmonavenenablation nach kurativer Behandlung von Vorhofflimmern

Zitierweise:

Christopher Piorkowski, M.D., Hans Kottkamp, M.D., Hildegard Tanner, M.D., Richard Kobza, M.D., Jens Cosedis Nielsen, M.D., Arash Arya, M.D., and Gerhard Hindricks, M.D.

Value of Different Follow-Up Strategies to Assess the Efficacy of Circumferential Pulmonary Vein Ablation for the Curative Treatment of Atrial Fibrillation.

J Cardiovasc Electrophysiol, Vol. 16, pp. 1286-1292, December 2005. 


\title{
Value of Different Follow-Up Strategies to Assess the Efficacy of Circumferential Pulmonary Vein Ablation for the Curative Treatment of Atrial Fibrillation
}

\author{
CHRISTOPHER PIORKOWSKI, M.D., HANS KOTTKAMP, M.D., HILDEGARD TANNER, M.D., \\ RICHARD KOBZA, M.D., JENS COSEDIS NIELSEN, M.D., ARASH ARYA, M.D., \\ and GERHARD HINDRICKS, M.D.
}

From the University of Leipzig, Heart Center, Department of Electrophysiology Strümpellstrasse, Leipzig, Germany

\begin{abstract}
Follow-Up Strategies After AF Catheter Ablation. Background: The objective of this study was to compare transtelephonic ECG every 2 days and serial 7-day Holter as two methods of follow-up after atrial fibrillation (AF) catheter ablation for the judgment of ablation success. Patients with highly symptomatic $\mathrm{AF}$ are increasingly treated with catheter ablation. Several methods of follow-up have been described, and judgment on ablation success often relies on patients' symptoms. However, the optimal follow-up strategy objectively detecting most of the AF recurrences is yet unclear.

Methods: Thirty patients with highly symptomatic AF were selected for circumferential pulmonary vein ablation. During follow-up, a transtelephonic ECG was transmitted once every 2 days for half a year. Additionally, a 7-day Holter was recorded preablation, after ablation, after 3 and 6 months, respectively. With both, procedures symptoms and actual rhythm were correlated thoroughly.

Results: A total of 2,600 transtelephonic ECGs were collected with 216 of them showing AF. $25 \%$ of those episodes were asymptomatic. On a Kaplan-Meier analysis $45 \%$ of the patients with paroxysmal AF were still in continuous SR after 6 months. Simulating a follow-up based on symptomatic recurrences only, that number would have increased to $70 \%$. Using serial 7-day ECG, 113 Holter with over 18,900 hours of ECG recording were acquired. After 6 months the percentage of patients classified as free from AF was $50 \%$. Of the patients with recurrences, $30-40 \%$ were completely asymptomatic. The percentage of asymptomatic AF episodes stepwise increased from $11 \%$ prior ablation to $53 \% 6$ months after.

Conclusions: The success rate in terms of freedom from AF was $70 \%$ on a symptom-only-based followup; using serial 7-day Holter it decreased to $50 \%$ and on transtelephonic monitoring to $45 \%$, respectively. Transtelephonic ECG and serial 7-day Holter were equally effective to objectively determine long-term success and to detect asymptomatic patients. (J Cardiovasc Electrophysiol, Vol. 16, pp. 1286-1292, December 2005)
\end{abstract}

atrial fibrillation, ablation, follow-up, 7-day Holter, transtelephonic ECG

\section{Introduction}

Curative treatment of atrial fibrillation (AF) is one of the major challenges of today's electrophysiology. The growing knowledge of initiating triggers and perpetuating substrate has led to the development of potentially curative catheter ablation procedures. ${ }^{1-3}$

However, inconsistent treatment results have caused difficulties judging the efficacy of the individual ablation approach. Apart from differences in patient selection, ablation technique, and experience, the varying results could also partly be due to differences in follow-up. Most commonly, freedom from AF symptoms was equated to freedom from $\mathrm{AF}$ and ablation success. ${ }^{1-4}$ However, this view only reflects one part of a complex clinical presentation with a variable occurrence and duration of AF episodes as well as

Address for correspondence: Christopher Piorkowski, M.D., University of Leipzig, Heart Center, Department of Cardiology/Electrophysiology, Strümpellstrasse 39, 04289 Leipzig, Germany. Fax: +49 3418651460; E-mail: CP7026@yahoo.de

Manuscript received 26 December 2004; Revised manuscript received 10 April 2005; Accepted for publication 11 May 2005.

doi: $10.1111 / \mathrm{j} .1540-8167.2005 .00245 . \mathrm{x}$ changes in AF perception after ablation. Asymptomatic AF has already been described for patient cohorts observed in population surveys such as the Framingham Study, in antiarrhythmic drug trials or following pacemaker implantation for sinus node dysfunction or AV-block. ${ }^{5-7}$ For the subset of patients with highly symptomatic AF these data are yet not available.

The present study assessed and compared the value of serial 7-day Holter versus transtelephonic ECGs every 2 days to determine ablation success following radiofrequency (RF) catheter interventional treatment of AF in highly symptomatic patients.

\section{Methods}

\section{Patient Selection and Characteristics}

Thirty consecutive patients ( 25 men, 5 women, mean age: $56 \pm 11$ years) presenting with highly symptomatic AF were included in this prospective study. The inclusion criteria required at least one ineffective trial of antiarrhythmic drug therapy, a history of AF longer than 18 months, and at least three ECG-documented AF episodes together with corresponding symptoms.

Twenty-six $(87 \%)$ patients suffered from paroxysmal AF, and $4(13 \%)$ patients from persistent $\mathrm{AF}$, respectively. 
Persistent AF was defined as continuous arrhythmia throughout the 7-day Holter prior to ablation. Organic heart disease was present in $5(17 \%)$ patients (coronary artery disease $\mathrm{n}=4$, valvular heart disease $\mathrm{n}=1)$, and $15(50 \%)$ patients had a history of arterial hypertension. Eleven $(37 \%)$ patients had so-called lone AF. Mean left ventricular ejection fraction measured $61 \pm 6 \%$, and mean left atrial (LA) diameter measured $40 \pm 7 \mathrm{~mm}$. The median history of AF was 5 years (range: 18 months-20 years). Prior attempts of AF ablation had been performed in $5(17 \%)$ patients, and isthmus ablation for common atrial flutter (AFLU) had been done in 2 (7\%) patients, respectively.

\section{Catheter Ablation Procedure}

The ablation concept based on a LA approach with induction of two circumferential lesions around the ostia of the left and the right pulmonary veins (PV), as well as two linear lesions from the left to the right PVs along the roof of LA and from the left PVs to the mitral annulus. ${ }^{1,2,8}$ The procedure was performed using an electroanatomical mapping system (Carto, Biosense Webster, Diamond Bar, CA, USA). ${ }^{2,3}$ Details about the procedure and the effect of the ablation on rhythm outcome and rhythm characteristics are described elsewhere. ${ }^{9}$ ECG recordings of atrial fibrillation longer than 30 seconds were counted as an episode of sustained arrhythmia recurrence.

\section{Follow-Up with 7-day Holter}

Following inclusion into the study and prior to ablation, a continuous 7-day ECG (Lifecard CF, DelmarReynolds Medical, Inc., Irvine, CA, USA) was recorded in all patients. It was repeated immediately after ablation, after 3 months, and after 6 months, respectively. The patients were equipped with a detailed symptom log. Complaints of tachycardia, palpitation, dyspnea, dizziness, and chest pain were taken as surrogates of AF. ${ }^{5}$ The single AF episode was classified as symptomatic or asymptomatic. Due to the difficulty in discriminating the symptomaticity in case of multiple short episodes $(<30 \mathrm{~min}$ utes) only separated by few minutes of sinus rhythm (SR), these episodes together were considered as a single one. Patients with documented AF were divided into three different groups of AF perception: only symptomatic patients, only asymptomatic patients, and patients with a mixture of symptomatic and asymptomatic AF.

ECG recordings of AFLU were analyzed separately. However, all patients showing AFLU presented episodes of AF during the same 7-day ECG, as well. Additionally, at the 6month follow-up none of the patients had arrhythmias other than AF.

\section{Follow-Up with Transtelephonic ECG}

Starting 7 days after ablation (after the postinterventional 7-day ECG), the patients transtelephonically transmitted a 12-lead electrocardiogram (Viapac, PTS HeartCare Telemedicine Services GmbH, Duesseldorf, Germany) once every 2 days throughout a 6-month period. In case of individual patients' complaints, unlimited additional transmissions were possible. The ECGs were received at the 24-hour ser- vice center of PTS HeartCare Telemedicine Germany, where physicians routinely supervised the quality of the incoming ECG transmission, took a detailed history, and acted in case of urgent clinical situations. A copy of every transtelephonic ECG recording was sent to our hospital and was reanalyzed by the supervising electrophysiologist. Heart rate and symptoms were collected for each episode. ECGs showing atypical AFLU and other supraventricular tachycardias were analyzed separately.

\section{Statistics}

Continuous variables are presented as mean \pm standard deviation (SD), if appropriate. In case of a non-Gaussian distribution, median and quartiles are given. Categorical variables are expressed as number and percentage of patients.

In case of follow-up with serial 7-day Holter, the change in the number of patients within the three AF perception groups as well as other categorical data such as the number of patients taking beta-blocker and antiarrhythmic drugs were tested for statistical significant difference using the chi-square test for trend. In case of a significant difference, each follow-up point was individually tested against the status prior to ablation. Changes of continuous data during follow-up, such as total AF duration, total AF episodes, percentage of asymptomatic AF hours, percentage of asymptomatic AF episodes, and the mean heart rate during AF were tested for statistical significant difference using the Friedman test. In case of a significant difference, each follow-up point was tested individually against the status prior ablation using the Mann-Whitney $U$-test and a Bonferroni correction.

In case of follow-up with transtelephonic ECGs, the occurrence of the initial AF relapse was measured and illustrated using a Kaplan-Meier survival analysis. In order to assess the phenomenon of early $\mathrm{AF}$ recurrences and only delayed cure after AF substrate modification, the analysis was performed without blanking period, after 1 month blanking, and 3 month blanking, respectively. For recurrences of AF and atypical AFLU, differences of the mean heart rate between symptomatic and asymptomatic episodes were tested for statistical significance using the Mann-Whitney $U$-test.

\section{Results}

\section{Follow-Up with 7-Day Holter}

Follow-up was complete for 30 patients prior to ablation, 30 patients postablation, 29 patients after 3 months, and 24 patients after 6 months, respectively. The number of patients with documented AF measured $28(93 \%)$ prior to ablation, $24(80 \%)$ postablation $(\mathrm{P}=0.214), 17(58 \%)$ after 3 months $(\mathrm{P}=0.021)$, and $13(54 \%)$ after 6 months $(\mathrm{P}=0.016)$, respectively (Table 1). Due to an early reablation $6(20 \%)$ patients did not complete 6 months of follow-up, with the reablation being performed before 3 months $(n=1)$ and between 3 and 6 months $(\mathrm{n}=5)$. Despite occasional asymptomatic $\mathrm{AF}$, none of the studied patients was completely asymptomatic during the 7-day Holter prior to ablation. Postinterventionally, the number of patients with only asymptomatic AF increased to 6 of $24(25 \%)$ patients postablation $(\mathrm{P}=0.014)$, 5 of $17(29 \%)$ patients after 3 months $(P=0.025)$, and 4 of 
TABLE 1

Rhythm Outcome and AF Perception on 7-Day Holter

\begin{tabular}{|c|c|c|c|c|}
\hline & Prior to Ablation & Postablation & 3 Months & 6 Months \\
\hline $\mathrm{N}$ patients & 30 & 30 & 29 & 24 \\
\hline $\mathrm{N}$ patients with $\mathrm{AF}$ & 28 & 24 & 17 & 13 \\
\hline Patients with only asymptomatic $\mathrm{AF}$ & $0(0 \%)$ & $6(25 \%)(P=0.014)$ & $5(29 \%)(\mathrm{P}=0.025)$ & $4(31 \%)(P=0.017)$ \\
\hline Patients with only symptomatic $\mathrm{AF}$ & $8(29 \%)$ & $4(17 \%)(P=0.124)$ & $3(18 \%)(\mathrm{P}=0.036)$ & $4(31 \%)(\mathrm{P}=0.23)$ \\
\hline Patients with symptomatic and asymptomatic $\mathrm{AF}$ & $20(71 \%)$ & $14(58 \%)(\mathrm{P}=0.081)$ & $9(53 \%)(\mathrm{P}=0.009)$ & $5(38 \%)(\mathrm{P}=0.003)$ \\
\hline $\mathrm{BB}$ & $17(61 \%)$ & $16(67 \%)(\mathrm{P}=0.386)$ & $14(82 \%)(\mathrm{P}=0.182)$ & $10(77 \%)(\mathrm{P}=0.144)$ \\
\hline AA (class Ic or III) & $15(54 \%)$ & $18(75 \%)(\mathrm{P}=0.094)$ & $13(76 \%)(\mathrm{P}=0.124)$ & $8(62 \%)(\mathrm{P}=0.377)$ \\
\hline Heart rate during $\mathrm{AF}$ (beats/min) & $108 \pm 20$ & $98 \pm 30(\mathrm{P}=0.083)$ & $101 \pm 17(\mathrm{P}=0.187)$ & $104 \pm 18(P=0.267)$ \\
\hline
\end{tabular}

The number of patients during follow-up, the number of patients with documented AF, the number of patients in each of the three AF perception groups (only symptomatic patients, only asymptomatic patients, symptomatic and asymptomatic patients), the number of patients with AF recurrences taking beta-blocker $(\mathrm{BB})$ and antiarrhythmic drugs (AA), and the mean AF heart rate at each time point during follow-up are shown in the table.

$13(31 \%)$ patients after 6 months $(P=0.017)$, respectively (Table 1).

\section{AF Characteristics}

During 7-day Holter, patients with AF showed an average of $3.3 \pm 0.9$ episodes prior to ablation, as compared to $3.5 \pm$ 1.1 postablation $(\mathrm{P}=0.992)$, to $2.6 \pm 1.2$ after 3 months $(P=0.132)$, and to $3.5 \pm 1.5$ after 6 months $(P=0.239)$, respectively (Table 2 ). The percentage of asymptomatic AF episodes increased from $10 \%$ prior to ablation to $50 \%$ postablation ( $\mathrm{P}=0.044)$, to $46 \%$ after 3 months $(\mathrm{P}=0.018)$, and to $53 \%$ after 6 months $(\mathrm{P}=0.011)$, respectively (Table 2).

The total AF duration during 7-day Holter declined from $59 \pm 14$ hours prior to ablation to $35 \pm 9$ postablation $(\mathrm{P}=0.054)$, to $23 \pm 8$ after 3 months $(\mathrm{P}=0.004)$, and to $16 \pm 5$ after 6 months ( $\mathrm{P}=0.001$ ), respectively (Table 2 ). The percentage of asymptomatic AF duration showed a nonsignificant trend from $40 \%$ prior to ablation, to $51 \%$ postablation ( $\mathrm{P}=0.134)$, to $58 \%$ after 3 months $(\mathrm{P}=$ $0.058)$, and to $54 \%$ after 6 months $(P=0.179)$, respectively (Table 2).

Along with the declining total AF duration, the mean length of all AF episodes significantly declined (Table 2). A comparison of the length between symptomatic and asymptomatic AF episodes revealed a significantly shorter duration for asymptomatic episodes, especially at 3 and 6 months of follow-up (Table 2). An analysis on daytime distribution did not show any significant difference between symptomatic and asymptomatic episodes (Table 2).

\section{Patients with Paroxysmal AF and Without Reablation}

An analysis on rhythm outcome and AF perception among the 20 patients with paroxysmal AF and no early reablation provided comparable results. The number of patients with documented AF decreased from 19 of 20 (95\%) patients prior to ablation to 15 of $20(75 \%)$ patients postablation ( $\mathrm{P}=0.063)$, to 10 of $20(50 \%)$ patients after 3 months $(\mathrm{P}=0.003)$, and to 10 of $20(50 \%)$ patients after 6 months $(\mathrm{P}=0.048)$, respectively (Fig. 1$)$. The number of patients with only asymptomatic AF among all patients with documented AF episodes during the 7-day Holter increased to 5 of $15(33 \%)$ patients postablation $(\mathrm{P}=0.018)$, to 4 of $10(40 \%)$ patients after 3 months $(P=0.013)$, and to 4 of $10(40 \%)$ patients after 6 months $(P=0.036)$, respectively (Fig. 1).

\section{Follow-Up with Transtelephonic ECG}

A total of 2,600 transtelephonic ECGs was recorded in our patients (in average $87 \mathrm{ECG}$ /patient). The mean follow-up time was 157 days. During follow-up, 216 AF ECGs were collected, with $53(25 \%)$ of them being asymptomatic. Of the 61 ECGs with atypical AFLU, $15(25 \%)$ showed to be asymptomatic.

TABLE 2

AF Characteristics on 7-Day Holter

\begin{tabular}{|c|c|c|c|c|}
\hline & Prior to Ablation & Postablation & 3 Months & 6 Months \\
\hline AF duration (hours) & $59 \pm 14$ & $35 \pm 9(\mathrm{P}=0.054)$ & $23 \pm 8(P=0.004)$ & $16 \pm 5(\mathrm{P}=0.001)$ \\
\hline Number of AF episodes & $3.3 \pm 0.9$ & $3.5 \pm 1.1(\mathrm{P}=0.992)$ & $2.6 \pm 1.2(\mathrm{P}=0.132)$ & $3.5 \pm 1.5(\mathrm{P}=0.239)$ \\
\hline Mean episode duration and range (hours) & $31(1-168)$ & $22(1-45)(P=0.145)$ & $16(1-74)(P=0.012)$ & $5(1-25)(\mathrm{P}=0.008)$ \\
\hline Asymptomatic $\mathrm{AF}$ (\% of $\mathrm{AF}$ duration) & $44 \pm 8$ & $51 \pm 9(\mathrm{P}=0.134)$ & $58 \pm 12(\mathrm{P}=0.058)$ & $54 \pm 13(\mathrm{P}=0.179)$ \\
\hline Asymptomatic $\mathrm{AF}$ ( $\%$ of $\mathrm{AF}$ episodes) & $10 \pm 4$ & $50 \pm 10(\mathrm{P}=0.044)$ & $46 \pm 13(\mathrm{P}=0.018)$ & $53 \pm 13(\mathrm{P}=0.011)$ \\
\hline $\begin{array}{l}\text { Duration of symptomatic vs } \\
\text { asymptomatic episodes (hours) }\end{array}$ & 11 vs $8(P=0.376)$ & 10 vs $13(P=0.266)$ & 12 vs $6(P=0.044)$ & 9 vs $2(\mathrm{P}=0.029)$ \\
\hline$\%$ daytime episodes ${ }^{*}$ & 46 vs $45(\mathrm{P}=0.872)$ & 67 vs $54(P=0.133)$ & 63 vs $56(P=0.343)$ & 83 vs $71(P=0.864)$ \\
\hline
\end{tabular}

symptomatic vs asymptomatic

$\mathrm{AF}$ characteristics before and after ablation with respect to $\mathrm{AF}$ duration, number of $\mathrm{AF}$ episodes, mean $\mathrm{AF}$ episode length, content of asymptomatic arrhythmia, duration of symptomatic versus asymptomatic episodes, and daytime distribution of symptomatic versus asymptomatic episodes are shown in the table.

*Episodes between 6 am and $10 \mathrm{pm}$. 


\section{Rhythm outcome and AF perception on 7-day-Holter in patients with paroxysmal AF and no re-ablation}

Figure 1. Diagram showing rhythm outcome for patients with paroxysmal $A F$ and no reablation. The number and percentage of patients with documented $A F$ during the 7-day ECG at each time point during follow-up are illustrated. The percentage of patients with only asymptomatic $A F$ among all patients with documented $A F$ is given in the lower part of the bars. The postinterventional decrease of patients showing $A F$, and the increase in the percentage of patients with only asymptomatic $A F$ was tested against the status prior ablation using the chi-square test for trend. The post hoc analysis against the status prior ablation was performed using the McNemar test $(* P<0.05)$.

\section{Rhythm Outcome}

Freedom from AF (the event free time to the first AF relapse) was analyzed and illustrated using a Kaplan-Meier survival analysis. Figure 2 shows the data for the 20 patients suffering from paroxysmal AF and without an early reablation. On that analysis 7 of $20(35 \%)$ patients remained in continuous SR at the end of study (Fig. 2a). In order to assess the phenomenon of early AF recurrences with only delayed cure after AF substrate modification, we recalculated the Kaplan-Meier analysis after introducing a blanking period of 1 and 3 months (Fig. 2b,c). AF recurrences during that blanking period were ignored and not considered as therapeutical failures. With that approach the success rate reached 9 of $20(45 \%)$ patients, similar with both blanking periods. That means, 2 of $20(10 \%)$ patients had AF recurrences during the first postinterventional months, but subsequently showed continuous SR only. Moreover, all patients with recurrences beyond the first postinterventional month continued to have AF relapses later on.

\section{AF Perception}

In order to analyze the impact of asymptomatic AF episodes on rhythm outcome, the Kaplan-Meier survival analysis was recalculated considering only symptomatic recurrences. This way we simulated a follow-up purely based on patients' symptoms, without any routine transmission, but the possibility to always and immediately transmit a transtelephonic ECG in case of subjective complaints. With that strategy the success rate would have improved. Without blanking period, 13 of $20(65 \%)$ patients would have been classified as free from AF at the end of the study (Fig. 2a). Considering a blanking period of 1 or 3 months, 14 of $20(70 \%)$ patients would have been counted as ablation success, as free from $\mathrm{AF}$, at the end of follow-up (Fig. 2b,c). That means, after AF ablation 6 of $20(30 \%)$ patients showed only asymptomatic AF on transtelephonic ECG recordings.

\section{Comparison of Follow-Up with 7-Day Holter and Transtelephonic ECG}

Using transtelephonic ECG recordings once every 2 days, a total of $216 \mathrm{AF}$ recurrences were collected during 6month follow-up. Twenty-five percent of these episodes were asymptomatic. Using serial 7-day Holter, a total of $233 \mathrm{AF}$ recurrences were collected during 6-month follow-up. Sixtyfive percent of these episodes were asymptomatic.

All of the 7 patients with continuous SR on transtelephonic ECG were in continuous SR during 3 and 6 months 7-day Holter, as well. Of 9 patients with continuous SR during both 3 and 6 months 7-day Holter, 2 patients showed additional symptomatic AF relapses on transtelephonic ECG. The first patient had a single AF episode 100 days after ablation, the second patient had rare AF episodes, about once per month.

However, for patients with paroxysmal AF and no reablation success in terms of freedom from $\mathrm{AF}$ judged from a follow-up with serial 7-day Holter was comparable to the success judged from a follow-up with transtelephonic ECG once every 2 days, at around $50 \%$ after 6 months.

\section{Concomitant Antiarrhythmic Medication}

As part of our study protocol, after ablation patients received a beta-blocker and an antiarrhythmic drug (class Ic or class III) for at least 3 months. Afterward the medication was adapted on an individual basis. Table 1 summarizes the medication for patients with documented AF recurrences during follow-up. Due to the study protocol, the percentage of patients taking beta-blocker showed a tendency to increase from $61 \%$ prior to ablation to $67 \%$ postablation, to $82 \%$ after 3 months, and to $77 \%$ after 6 months, however, not statistically significant. The usage of antiarrhythmic drugs showed a related pattern (Table 1 ).

A comparison of beta-blocker and antiarrhythmic drug treatment between patients with only asymptomatic $\mathrm{AF}$ and patients with at least partially symptomatic AF did not show any significant difference at any time during follow-up. 


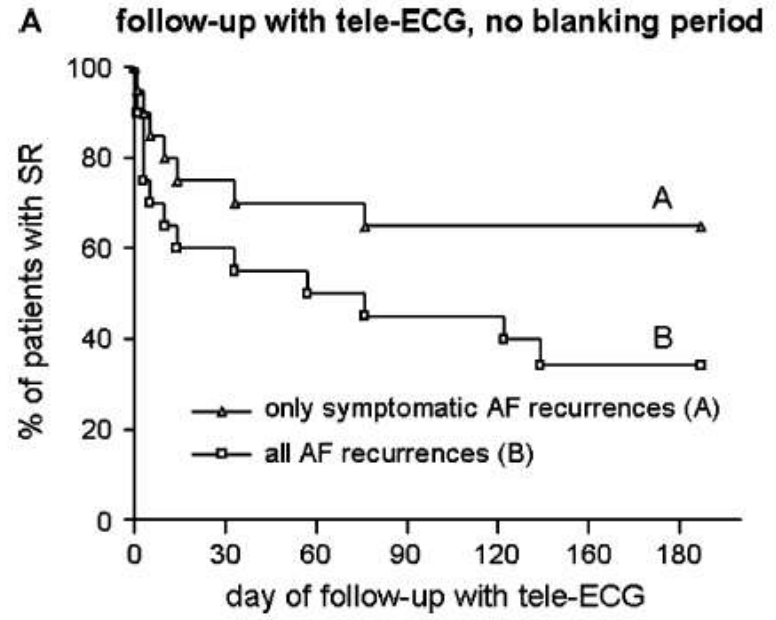

$B$ follow-up with tele-ECG, blanking period 1 month

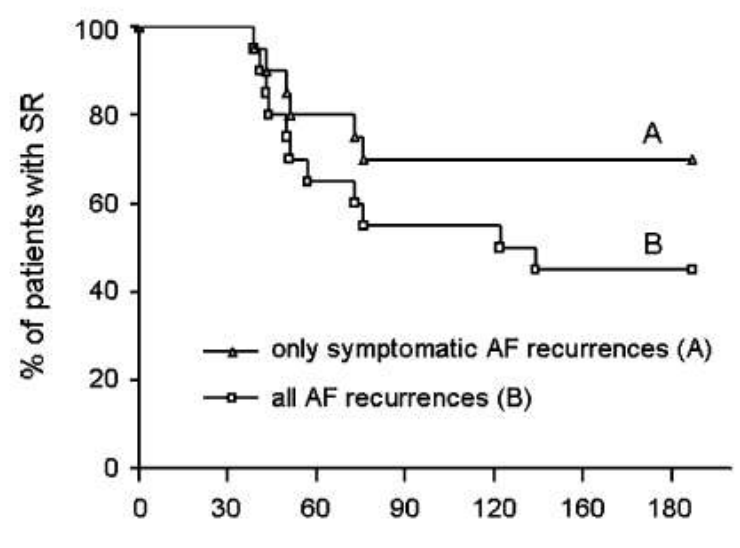

day of follow-up with tele-ECG

C follow-up with tele-ECG, blanking period 3 months

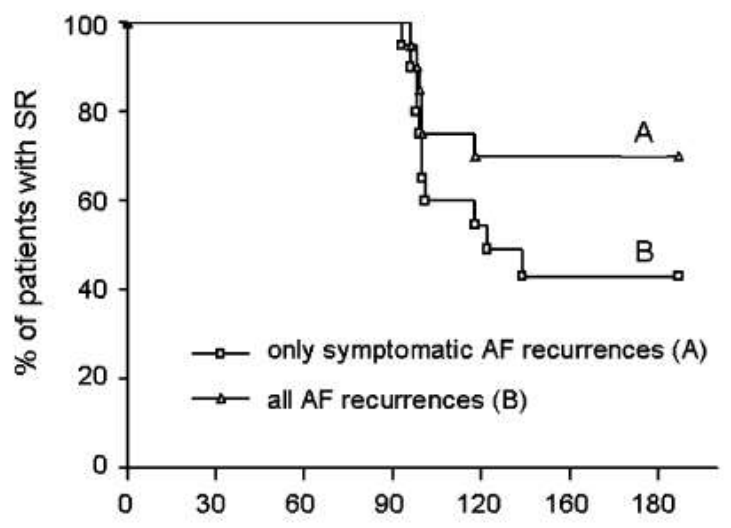

day of follow-up with tele-ECG

Figure 2. Diagram showing the postinterventional follow-up after $A F a b$ lation using transtelephonic ECG transmissions every 2 days. The time to the first AF relapse is illustrated on a Kaplan-Meier survival analysis. Plot $B$ represents the analysis including all documented $A F$ recurrences. Plot $A$ represents the analysis including only symptomatic $A F$ recurrences and thereby simulating a symptom-only-based follow-up. Figure $2 a$ shows the analysis without any blanking period. In Figure $2 b$, a blanking period of $I$ month was introduced. AF recurrences during that month were ignored and not considered as therapeutical failures. In Figure $2 c$, the blanking period was extended to 3 months. The long-term outcome did not change compared to the 1-month blanking, suggesting that all patients with $A F$ recurrences after the first postinterventional month continued to have $A F$ recurrences.

\section{AF Heart Rate and AF Perception}

Table 1 illustrates the mean AF heart rate for patients with documented recurrences during follow-up with serial 7-day Holter (Table 1). Additionally, the mean AF heart rate was compared between patients with only asymptomatic arrhythmia and patients with at least partially symptomatic arrhythmia. No significant difference could be found.

In case of follow-up with transtelephonic ECG, a comparison of the AF heart rate between symptomatic and asymptomatic episodes was performed. Again, no statistically significant difference could be found (median 109 beats/min [interquartiles $93 ; 125$ ] versus median 103 beats/min [interquartiles $85 ; 122$ ]; $\mathrm{P}=0.734$ ). However, for recurrences of atypical AFLU, asymptomatic episodes had a significantly lower heart rate as compared to symptomatic episodes (median 94 beats/min [interquartiles: $60 ; 125$ ] versus median 128 [interquartiles: $84 ; 142$ ]; $\mathrm{P}=0.042$ ).

\section{Discussion}

\section{Main Findings}

On a symptom-only-based follow-up, the success rate after AF ablation would have reached $70 \%$. With two methods of close postinterventional monitoring (serial 7-day Holter and transtelephonic ECG once every 2 days) that outcome was reduced to $50 \%$ and $45 \%$, respectively. Both methods were equally effective in detecting patients with only asymptomatic AF. These findings may have important implications on strategy and intensity of follow-up after AF catheter ablation procedures.

\section{Comparison of Follow-Up with 7-Day Holter and Transtelephonic ECG}

The present study used two methods of follow-up over a period of half a year to conduct the closest observation after an AF catheter ablation that has been reported so far. Each of these two methods carries advantages and disadvantages.

The transtelephonic ECG provides a snapshot procedure that can cover the follow-up period without any longer lasting unobserved time periods in between, and additionally enables the patient to document an ECG during any symptomatic complaint. However, asymptomatic episodes outside that snapshot can go unrecognized. Accordingly, the present study showed $25 \%$ of all AF episodes recorded on transtelephonic ECG to be asymptomatic as compared to $65 \%$ of all AF episodes recorded on serial 7-day Holter. That suggests, that even with transtelephonic ECG every other day additional asymptomatic episodes are missed in between, and a continuous registration is superior to the snapshot procedure in that respect.

The 7-day Holter, on the other hand, is able to continuously monitor a large time frame and very accurately describe the AF burden with respect to the number of AF episodes and total AF duration. On the other hand, AF recurrences between the defined follow-up points may go unrecognized. Accordingly, in the present study 2 patients were affected by that disadvantage.

However, considering total ablation success in terms of freedom from $\mathrm{AF}$ for patients with paroxysmal $\mathrm{AF}$ and no reablation, both methods gave comparable results 3 and 6 months after ablation. 


\section{Clinical Implications}

With two different methods of follow-up, our study showed a significant development of asymptomatic AF after RF catheter ablation. A substantial number of patients became completely asymptomatic. On a symptom-only-based follow-up, these patients would have been neglected, and the success rate would have been overestimated. That way our study may help to explain varying data on success rates of $\mathrm{AF}$ catheter ablation reported in the literature.

For the individual patient, the most significant implication of asymptomatic $\mathrm{AF}$ is related to the need for oral anticoagulation after the ablation procedure. It may be argued that the average duration of asymptomatic episodes was too short to carry a significant thromboembolic risk. However, among our study cohort, we also found patients with 76 hours of completely asymptomatic AF. Patient characteristics failed to identify the individuals at risk for asymptomatic AF. Thus, withdrawal of oral anticoagulation after ablation should be considered carefully based on reliable and objective measures such as long-term Holter rather than on symptoms.

Both methods of follow-up resulted in similar success rates after 6 months of observation. Therefore, each of them could be used as a follow-up routine after AF ablation.

\section{Change of AF Perception After RF Catheter Ablation}

In the present study, a substantial and increasing amount of asymptomatic AF episodes was observed following $\mathrm{AF}$ catheter ablation. On serial 7-day Holter, the average proportion of asymptomatic AF episodes among all episodes increased from $11 \%$ prior ablation to $53 \%$ at the 6 -month follow-up. On transtelephonic ECG, $25 \%$ of all postinterventionally recorded $\mathrm{AF}$ episodes showed to be asymptomatic.

With respect to the judgment of ablation success, the number of patients with only asymptomatic $\mathrm{AF}$ recurrences is of utmost interest. During the 7-day Holter prior to ablation, none of the patients was completely asymptomatic, characterizing a population of truly highly symptomatic patients. During the postinterventional 7-day Holter, the percentage of patients with only asymptomatic AF increased by $30-40 \%$. Certainly, serial 7-day Holter do not account for possibly symptomatic AF recurrences in between. However, also on transtelephonic ECG, 6 patients showed only asymptomatic AF recurrences throughout follow-up. Neglecting them would have increased ablation success from $35 \%$ to $65 \%$ without blanking period, and from $45 \%$ to $70 \%$ with a blanking period of 1 or 3 months.

\section{Causes of Asymptomatic AF}

The reason for the postinterventional occurrence and increase of asymptomatic AF remains unclear. First, the LA AF ablation may change the pattern of the arrhythmia. Details about rhythm outcome and arrhythmia characteristics observed in our patients are presented elsewhere. ${ }^{9}$ As a general pattern, in case of postinterventional recurrences the number of AF episodes stayed unchanged and the duration of the single episode decreased. Indeed, we found asymptomatic AF episodes to be significantly shorter than symptomatic ones. An analysis on daytime distribution of symptomatic versus asymptomatic episodes failed to detect a nocturnal predominance of asymptomatic episodes. By comparing patients with different AF perception after ablation, no signif- icantly different AF pattern (duration, episodes, and mean $\mathrm{AF}$ heart rate) could be found. Interestingly, in case of the more regular atypical AFLU asymptomatic episodes showed a significantly lower heart rate than symptomatic ones. That finding suggests that factors like regularity of the heart beat may additionally influence the perception of the arrhythmia. Second, the postinterventional medication could be seen as responsible for the observed change of AF perception. Nevertheless, patients with different AF perception showed the same amount of beta-blocker intake and antiarrhythmic drug usage at any time during follow-up. Third, a placebo effect cannot be excluded. However, the present study was nonrandomized and nonblinded in nature. Therefore, a placebo effect cannot be assessed. However, reports from Berkowitsch et al. and Gerstenfeld et al., who described an improved quality of life despite AF recurrences following PV isolation procedures, support that point of view. ${ }^{10,11}$ Finally, changes of the cardiac autonomic nervous system described after a LA RF ablation might have had an impact on the change of AF perception. ${ }^{12}$ Nevertheless, currently that issue is not completely understood, and further studies are needed for clarification.

In a recent study, Oral et al. described the prevalence of symptomatic and asymptomatic atrial fibrillation following apparently successful segmental PV disconnections. ${ }^{13}$ The authors stated that asymptomatic AF episodes are infrequent following apparently successful catheter ablation procedures. The data presented by Oral et al. may be interpreted as being inconsistent with the findings of our study. However, this may at least partially be due to significant differences in the study protocols. When comparing the results of the study by Oral et al. with our data, the important methodological limitations of their study must be considered, which have also been addressed in detail in an editorial published along with their manuscript. ${ }^{14}$ One interesting and unanswered question regarding the data from Oral et al. relates to the fact that $12 \%$ of patients being completely free from symptomatic AF from 6 months to almost 2 years after ablation suddenly develop symptomatic recurrences within a mean of only 25 days after having been equipped with an event recorder. Overall, the discrepant results obtained in both studies underline the need for additional detailed investigations. ${ }^{14}$

\section{Study Limitations}

Influences of patient selection confounding the postinterventional AF perception cannot be excluded. However, patient characteristics in our study match data from other studies published on AF catheter ablation, without striking differences. ${ }^{2,3}$ Additionally, the issue of all patients being highly symptomatic at baseline prior to ablation has been discussed above.

\section{References}

1. Haissaguerre M, Jais P, Shah DC, Takahashi A, Hocini M, Quiniou G, Garrigue S, Le Mouroux A, Le Metayer P, Clementy J: Spontaneous initiation of atrial fibrillation by ectopic beats originating in the pulmonary veins. N Engl J Med 1998;339:659-666.

2. Pappone C, Oreto G, Rosanio S, Vicedomini G, Tocchi M, Gagliotta F, Salvati A, Bicandia C, Calako MP, Marzone P. Ficarra E, Di Gioia C, Galletta S, Nardi S, Santinelli V, Berussi S, Alfieri D: Atrial electroanatomic remodelling after circumferential radiofrequency 
pulmonary vein ablation. Efficacy of an anatomic approach in a large cohort of patients with atrial fibrillation. Circulation 2001;104:25392544 .

3. Oral H, Scharf C, Chugh A, Hall B, Cheung P, Good E, Veerareddy $\mathrm{S}$, Pelosi F Jr, Morady F: Catheter ablation for paroxysmal atrial fibrillation: Segmental pulmonary vein ostial ablation versus left atrial ablation. Circulation 2003;108:2355-2360.

4. Ernst S, Schlüter M, Ouyang F, Khanedani A, Cappato R, Hebe J, Volkmer M, Antz M, Kuck KH: Modification of the substrate for maintenance of idiopathic human atrial fibrillation. Efficacy of radiofrequency ablation using nonfluoroscopic catheter guidance. Circulation 1999;100:2085-2092.

5. Levy S, Maarek M, Coumel P, Guize L, Lekieffre J, Medvedowsky JL, Sebaoun A: Characterization of different subsets of atrial fibrillation in general practice in France, The ALFA Study. Circulation 1999;99:30283035 .

6. Page RL, Tilsch TW, Connolly SJ, Schnell DJ, Marcello SR, Wilkinson WE, Pritchett EL: Azimilide Supraventricular Arrhythmia Program (ASAP) Investigators. Asymptomatic or "Silent" atrial fibrillation. Frequency in untreated patients and patients receiving azimilide. Circulation 2003:107:1141-1145.

7. Israel CW, Gronefeld G, Ehrlich JR, Li YG, Hohnloser SH: Long-term risk of recurrent atrial fibrillation as documented by an implantable monitoring device. J Am Coll Cardiol 2004:42:47-52.

8. Kottkamp H, Hindricks G, Autschbach R, Krauss B, Strasser B, Schirdewahn P, Fabricius A, Schuler G, Mohr FW: Specific linear left atrial lesions in atrial fibrillation: Intraoperative radiofrequency abla- tion usingminimally invasive surgical techniques. J Am Coll Cardiol 2002; $40: 475-480$

9. Kottkamp H, Tanner H, Kobza R, Schirdewahn P, Dorszewski A, GerdsLi JH, Carbucicchio C, Piorkowski C, Hindricks G: Time course and quantitative analysis of atrial fibrillation episode number and duration after circular plus linear left atrial ablation; Trigger elimination or substrate modification, early or delayed cure? J Am Coll Cardiol 2004;44:869-877.

10. Berkowitsch A, Neumann T, Kurzidim K, Reiner C, Kuniss M, Siemon G, Sperzel J, Pitschner HF: Comparison of generic health survey SF36 and arrhythmia related symptom severity check list in relation to post-therapy AF recurrence. Europace 2003;5:351-355.

11. Gerstenfeld EP, Guerra P, Sparks PB, Hattori K, Lesh MD: Clinical outcome after radiofrequency catheter ablation of focal atrial fibrillation triggers. J Cardiovasc Electrophysiol 2001;12:900-908.

12. Pappone C, Santinelli V, Manguso F, Vicedomini G, Gugliotta F, Augello G, Mazzone P, Tortoriello V, Landoni G, Zangrillo A, Lang C, Tomita T, Mesas C, Mastella E, Alfieri O: Pulmonary vein denervation enhances long-term benefit after circumferential ablation for paroxysmal atrial fibrillation. Circulation 2004;109:327-334.

13. Oral H, Veerareddy S, Good E, Hall B, Cheung P, Tamirisa K, Han J, Fortino J, Chugh A, Bogun F, Pelosi F Jr, Morady F: Prevalence of asymptomatic recurrences of atrial fibrillation after successful radiofrequency catheter ablation. J Cardiovasc Electrophysiol 2004;15:920924.

14. Callans D: Asymptomatic atrial fibrillation in symptomatic patients. J Cardiovasc Electrophysiol 2004:15:925-926. 


\section{Diskussion und Ausblick}

Technologische Entwicklungen zur Umsetzung aktueller und künftiger

\section{Ablationskonzepte}

Das pathophysiologische Verständnis elektrophysiologischer Veränderungen wie ektoper Triggeraktivität und Reentry-vermitteltem Arrhythmiesubstrat sowie derer anatomischen Prädilektionsstellen führte zur Beschreibung von Ablationskonzepten mit dem Ziel einer potentiell kurativen Therapie von Patienten mit Vorhofflimmern. Die zirkumferentielle elektrische Isolation der großen Pulmonalvenentrichter am posterioren linken Vorhof ist aktuell das am weitesten verbreitete Verfahren zur Behandlung von Patienten mit paroxysmalem Vorhofflimmern und ein wesentlicher Grundbaustein der Konzepte zur Behandlung von Patienten mit persistierendem Vorhofflimmern. Letztere unterscheiden sich durch eine vorrangige pathophysiologische Beteiligung des Arrhythmiesubstrates im Gegensatz zu einer nur untergeordneten Rolle der Vorhofflimmertrigger. Bedingt durch diese pathophysiologische Verschiebung, die typischerweise mit anatomisch strukturellen Veränderungen wie Dilatation und Fibrosierung des linken Vorhofes einhergeht, benötigen diese Patienten weitere über die zirkumferentielle Isolation der Pulmonalvenentrichter hinausgehende Behandlungskonzepte zur zusätzlichen Substratmodifikation ${ }^{36}$. Angelehnt am Modell der multiplen Wellentheorie bzw. den anatomisch stabilen „Anchor"-Reentry-Kreisen und aufbauend auf kardiochirugischen Erfahrungen werden bei diesen Patienten häufig lineare Ablationslinien im Körper des linken bzw. rechten Vorhofes eingesetzt ${ }^{7 ; 20}$. Ein anderer Ansatz besteht in der so genannten atrialen Defragmentierung, bei der spezifische lokale Elektrogramkriterien wie Niedervoltage, fragmentierte QRS-Morphologie und 
verlängerte QRS-Dauer verwendet werden, um Substrat-tragende Myokardareale als zusätzliche Ablationsziele zu identifizieren ${ }^{36}$. Wissenschaftlich gesehen besteht aktuell Unklarheit, welche dieser über die alleinige zirkumferentielle Pulmonalvenenisolation hinausgehenden Ablationskonzepte bei Patienten mit persistierendem Vorhofflimmern mit welchem prozeduralen Endpunkt eingesetzt werden sollten.

Neben der Frage der objektiven Erfolgskontrolle nach Ablation, die im Abschnitt zum Rhythmusmonitoring diskutiert wird, resultiert die Schwierigkeit der Beurteilung und des Vergleiches der Effektivität verschiedener Ablationskonzepte aus Limitierungen bei der praktischen Umsetzung des theoretischen Konzeptes in jedem einzelnen individuellen Patienten. Bereits die für Patienten mit paroxysmalem Vorhofflimmern als Standard angesehene zirkumferentielle Pulmonalvenenisolation stellt eine katheterinterventionelle Herausforderung dar. Im klinischen Alltag führt dies zu langen Prozedur- und Durchleuchtungszeiten und einer hohen Zahl an Rezidiven von Vorhofflimmern und Vorhofflattern wegen (1) primär nicht erreichtem prozeduralem Endpunkt mit inkompletter Isolation ${ }^{52}$, (2) zu distal isolierten Pulmonalvenen mit unbehandeltem Vorhofflimmersubstrat im proximalen Antrum ${ }^{53}$, und (3) einer hohen Zahl an Patienten mit Erholung der Pulmonalvenenleitung ${ }^{54}$.

Die Schwierigkeiten der praktischen katheterinterventionellen Umsetzung theoretischer kurativer Ablationskonzepte sind im Wesentlichen bedingt durch Limitationen der dreidimensionalen anatomischen Orientierung innerhalb komplexer und interindividuell stark variabler anatomischer Zielstrukturen, durch Limitationen eines verlässlichen und stabilen Katheterzuganges in jedem Zielareal trotz schlagendem Herzen und atmendem Patienten, und durch Limitationen in der 
Abschätzung und Titrierung des für eine lokale transmurale Läsion nötigen Energietransfers. Aufgrund dieser Schwierigkeiten, ist sowohl von wissenschaftlicher als auch von klinischer Seite ein starkes Interesse an technologischen Entwicklungen zur Verbesserung von Orientierung, Zugang und Energietransfer entstanden. Vor diesem Hintergrund wurden im Rahmen der vorliegenden Habilitationsschrift Originalpublikationen vorgestellt, die entsprechende Technologien und Ansätze entwickelt, eingeführt und validiert haben.

Unter der Fragestellung der Genauigkeit des Verständnisses und der Abbildung der dreidimensionalen Anatomie in den Zielarealen der Vorhofflimmerablation wurden herkömmlich elektroanatomisch rekonstruierte virtuelle Vorhofanatomien gegenüber den realen - aus Schnittbildverfahren erzeugten - 3D Anatomien verglichen. Es zeigte sich, dass obwohl erfahrene Untersucher eine in weiten Anteilen realitätsnahe Vorhofanatomie rekonstruieren können, systematische Ungenauigkeiten bedingt durch Limitationen des Katheterzuganges und der örtlichen Auflösung der Rekonstruktion bestehen bleiben. Zur Verbesserung des Verständnisses der individuellen 3D Anatomie und ihrer Berücksichtigung bei der Planung entsprechender Ablationslinien entwickelten wir ein Modell-integriertes Verfahren zur Ablation von Vorhofflimmern und Vorhofflattern. Das Verfahren basiert auf der Erzeugung eines kardialen CT-Schnittbildes. Aus diesem wird durch entsprechende Segmentierung der linke Vorhof dreidimensional herausgearbeitet. Der kritische Schritt ist die Registrierung dieses dreidimensionalen Modells in die tatsächliche 3D Position während der Ablation. Der von uns entwickelte Registrierungsansatz basierte auf der Identifizierung der Pulmonalvenen als stabile dreidimensionale Registrierungsmarker. Nach erfolgter Registrierung wurden Linienplanung und 
Ablation in dem 3D Modell durchgeführt. Unser Verfahren ist der erste vollständig Bild-integrierten therapeutische Einsatz im Bereich der interventionellen Kardiologie, der inzwischen Eingang in die klinische Routine gefunden hat. Für die Zukunft zeichnen sich weitere Entwicklungen im Bereich der Bilderzeugung und im Bereich der Bildregistrierung ab. Für die Bilderzeugung zeigen sich Entwicklungstrends in Richtung von Verfahren, die dreidimensionale Vorhofmodelle nicht in zweitzeitigen CT-Untersuchungen sondern während des Ablationseingriffes mittels Rotationsangiographie oder 3D-Echokardiographie erstellen können. Vorteile liegen neben der Reduktion der Strahlenexposition des Patienten in der Erzeugung eines aktuelleren Vorhofmodelles entsprechend dem aktuellen Rhythmus und dem aktuellen Füllungszustand des Herzens. Diese Formen der periprozeduralen 3DBildgebung ebenen weiterhin den Weg für verbesserte und möglicherweise automatisierte Registrierungsverfahren, mit denen das 3D Modell bereits in der richtigen räumlichen Position ausgerichtet wird. Solche Ansätze haben das Potential sowohl den transseptalen Zugang und die Orientierung im linken Vorhof als auch die Ablation an sich, insbesondere für unerfahrenere Interventionalisten, deutlich zu vereinfachen. Da kardialer Zyklus und Atemvariabilität eine grundsätzliche Limitation der Integration statischer Bilder darstellen, ist das weiterreichende Ziel eine 4D Bildgebung des Herzens zur zeitabhängigen Visualisierung der 3D Anatomie und des Ablationskatheters über den gesamten kardialen Zyklus ausgestattet mit zusätzlichen Kompensationsalgorithmen für Atmungs-bedingte Verschiebungen der Zielanatomien. Neben den erwähnten Entwicklungsansätzen trägt auch das Konzept einer Ablation in MRT-Umgebung das Potential derartige Fragen grundsätzlich zu lösen. 
Im Hinblick auf aktuelle Limitationen der Umsetzung katheterinterventioneller Ablationskonzepte bedingt durch Probleme der Katheterstabilität und des Energietransfers haben wir in entsprechende Studien neue KatheterZugangstechnologien validiert und eine Methode eingeführt, mit der der elektrische Kontakt zwischen Ablationskatheter und Myokard gemessen und als potentieller Indikator für den Energietransfer bei Ablation verwendet werden kann. Es zeigte sich, dass der Einsatz langer manuell kontrollierter steuerbarer Schleusentechnologien Probleme der Katheterstabilität an schwierigen Prädilektionsstellen deutlich reduzierte und einen effizienteren Energietransfer ins Gewebe vermittelte. Periprozedural führte dies zu einer signifikanten Steigerung der Patienten bei denen eine vollständige Isolation der Pulmonalvenen erreicht wurde. Klinisch zeigte sich im 6-Monats-Verlauf ein Zuwachs der Erfolgsrate (Freiheit von Vorhofflimmern und Vorhofflattern) um ca $20 \%$. Hervorzuheben ist, dass diese Technologie eine relativ einfache Verbesserung der bereits bisher genutzten Zugangswege und Zugangsmethoden darstellt, ohne den Bedarf für kostenintensive Laborinvestitionen, wie es beispielsweise Roboter-gestützte Navigationshilfen benötigen. Der Hauptmechanismus über den steuerbare Schleusen erhöhte Katheterstabilität und verbesserten Energietransfer vermitteln liegt in einem verbesserten Kontakt zwischen Ablationselektrode und Myokard in allen Zielarealen der Ablation. Erhöhter Kontakt stellt immer aber auch ein Risiko für unkontrollierte Energieübergänge, Gewebsüberhitzungen, Verkochungen und Perforationen/Tamponaden dar. In unserer Studie zeigte sich übereinstimmend mit unseren klinischen Erfahrungen keine Zunahme der diesbezüglichen Komplikationsrate. Ob dies für unerfahrenere Interventionalisten in gleichem Maße gilt bleibt offen. 
Technologien, die Katheterkontakt über die individuelle Erfahrung hinaus objektivierbar messen und beschreiben können, haben prinzipiell das Potential überschießende und gefährliche Kontaktsituationen anzuzeigen. Gegenwärtig gibt es zwei Ansätze Kontakt objektivierbar zu messen. Der erste Ansatz beruht auf der Analyse des mechanischen Andruckes des Katheters am Myokard. Insbesondere vom Aspekt der Vermeidung mechanisch bedingter Perforationen ist dies ein interessantes Konzept ${ }^{55}$. Einschränkungen ergeben sich aus dem Einfluss der Orientierung der Katheterspitze und der fehlenden Aussage über den tatsächlichen elektrischen Energietransfer bei Ablation. Ein zweiter Ansatz zur objektivierbaren Kontaktanalyse beruht auf der Bestimmung der lokalen elektrischen Widerstände zwischen Katheter und Myokard. Diese Technologie wurde von uns erstmalig im Menschen eingesetzt und verblindet validiert. Sie ist unabhängig von der Orientierung der Katheterspitze und zeigt interessante Veränderungen während der Ablation, die potentiell mit dem Ausmaß des Energietransfers und der Läsionsbildung im Myokard korrelieren. Die Frage nach Verbesserungen harter klinischer Ablationsergebnisse (Prozedurdauer, Erfolg, Komplikationen) durch den Einsatz neuer Kontakttechnologien muss in entsprechenden klinischen Studien untersucht werden und wird darüber entscheiden, ob diese Verfahren ihren Eingang in die klinische Routine finden werden.

Mit der Etablierung sicherer technologischer Lösungen zur reproduzierbaren praktischen Applikation theoretischer Ablationskonzepte werden sich in Zukunft die diesbezüglichen Voraussetzungen verbessern, um Ablationskonzepte in der klinischen Praxis gründlicher evaluieren und vergleichen zu können. Damit entstehen Möglichkeiten für modernere pathophysiologische Ansätze, die dem Prinzip - so viel 
Ablation wie nötig, aber so wenig Ablation wie möglich - besser Rechnung tragen können, als gegenwärtige Linienkonzepte. Denn obwohl die zirkumferentielle Pulmonalvenenisolation als therapeutischer Standard weitestgehend anerkannt ist, gibt es bis heute keine schlüssigen pathophysiologischen Erklärungen für die klinische Beobachtung einer großen Zahl an Patienten, die von Vorhofflimmern geheilt werden konnten obwohl (1) die Pulmonalvenen niemals isoliert waren oder ${ }^{21}$ (2) eine signifikante Leitungserholung eingetreten ist ${ }^{56}$. Die erfolgreiche Behandlung des Flimmersubstrates erscheint als einzige plausible Erklärung für diese Beobachtung, was andererseits die Bedeutung der effektiven Substratbehandlung für alle Patienten mit Vorhofflimmern unterstreicht. Für zukünftige Ablationskonzepte stellte sich damit die Frage nach der dreidimensionalen Identifizierung, Lokalisation und Visualisierung des Flimmersubstrates, möglicherweise basierend auf zellulären und subzellulären Veränderungen. Unter Verwendung der vorgestellten Orientierungs- und Kathetertechnologien böte ein solcher Ansatz die Möglichkeit die Ablation ausschließlich auf die arrhythmogenen Areale des Flimmersubstrates zu fokussieren, ohne in gesunden Myokardbereichen abladieren zu müssen, mit all den zusätzlich assoziierten Komplikationsrisiken.

\section{Komplikationsrisiken und Komplikationsvermeidung}

In den letzten Jahren hat sich die Katheterablation von Vorhofflimmern aus einem Verfahren der Neulandmedizin in den Bereich einer klinischen Standardindikation entwickelt. In entsprechenden Leitlinien wird die Therapie bei symptomatischen Patienten als Indikation der zweiten Wahl nach erfolglos versuchtem medikamentös antiarrhythmischem Rhythmuserhalt eingestuft ${ }^{17}$. Inzwischen mehren sich publizierte wissenschaftliche Studien, die die Katheterablation von Vorhofflimmern als 
Primärtherapie gegenüber dem medikamentös antiarrhythmischen Rhythmuserhalt verglichen haben $40 ; 57$; 58 Übereinstimmend berichten diese Arbeiten nach Katheterablation eine hochsignifikante Zunahme der Patienten bei denen eine Freiheit von Vorhofflimmerrezidiven erreicht werden konnte. Von Seiten der Effektivität stellt die Katheterablation von Vorhofflimmern damit ein wesentlich erfolgreicheres rhythmuserhaltendes Therapiekonzept dar, als die bisher verfügbaren medikamentösen Antiarrhythmika. Neben der Effektivitätsanalyse bedarf die Beurteilung eines Therapieverfahrens allerdings auch einer Analyse der Komplikationsraten. Erst in dieser Kombination lässt sich der Wert einer spezifischen Behandlungsstrategie ableiten.

Bisherige wissenschaftliche Daten zu Komplikationsraten der Vorhofflimmerablation sind inkonsistent. Einerseits unterliegen sie dem Bias, dass bestimmte Komplikationen mit der Erfahrung des Interventionalisten assoziiert sind. Dementsprechend berichten große Ablationszentren sehr niedrige Komplikationsraten 40; 41. Andererseits entwickeln sich Ablationsmethoden und Ablationsstrategien ständig weiter, was zu grundsätzlich unterschiedlichen Prozeduren mit unterschiedlichen Komplikationsrisiken führt. Als Beispiel ist die Pulmonalvenenstenose als typische und häufige Komplikation der segmentalen Pulmonalvenen-Diskonnektion zu nennen, die im Rahmen der zirkumferentiellen Pulmonalvenenablation nur noch in seltenen Einzelfällen auftritt. Vor diesem Hintergrund haben die Daten weltweiter Registerbefragungen zu Komplikationsrisiken der Vorhofflimmerablation ebenfalls nur eine beschränkte Aussagekraft ${ }^{42}$. Zusätzlich zu den erwähnten Einflussfaktoren wird die Beurteilung der Komplikationsraten auch durch die Intensität und Dichte der Nachkontrolle nach 
Vorhofflimmerablation bestimmt. Einige Komplikationen, wie beispielsweise die Ausbildung einer atrio-ösophagealen Fistel manifestieren sich erst in den Tagen und Wochen nach der Ablation. Im Falle einer fehlenden engmaschigen Nachkontrolle werden diese dann weder erkannt, noch erfasst oder berichtet.

Zur Beurteilung der Risiken eines Verfahrens, dass in unserer Abteilung zunehmend in der klinischen Routine durchgeführt wird, haben wir im Rahmen einer wissenschaftlichen Untersuchung die Komplikationen der Katheterablation von Vorhofflimmern bei allen 1000 Patienten, die konsekutiv zwischen Oktober 2005 und Januar 2008 von uns behandelt worden sind, erfasst, analysiert und publiziert. Es bleibt hervorzuheben, dass alle Patienten prinzipiell identisch eine zirkumferentielle Pulmonalvenenisolation erhalten hatten, dass die Behandlungen von mehr und weniger erfahrenen Elektrophysiologen durchgeführt worden sind, und das kein Patient in der Nachkontrolle verloren ging. Im Rahmen der Untersuchung zeigte sich eine Rate an schweren Komplikationen von 3,9\%. Die häufigsten schweren Komplikationen waren Perikardtamponaden und femorale Zugangskomplikationen. Beide konnten in nahezu allen Fällen konservativ/interventionell ohne kardiochirurgische oder gefäßchirurgische Intervention und ohne langfristige Folgeschäden behoben werden. Langfristige Schäden zeigten sich bei 5 der 1000 Patienten (0,5\%). Hierbei zusammengefasst sind 2 Patienten, die in den Wochen nach Ablation verstorben sind, 1 Patienten mit überlebtem Schlaganfall und 2 Patient mit überlebter Ösophagusperforation. Bei den Todesfällen handelt es sich um einen Patienten mit unklarem plötzlichen Herztod und einen Patienten mit anamnestisch hochgradigem Verdacht auf eine atrio-ösophageale Fistel. Somit stellte die Ösophagusverletzung das wesentlichste Risiko für das Auftreten 
langfristiger Folgeschäden nach Katheterablation von Vorhofflimmern dar. In unserer Kohorte verursachte sie 3/5 Komplikationen mit Langzeitschäden, und sie war mit einer unmittelbaren Mortalität von 33\% assoziiert. Im weiteren klinischen Verlauf über den Studienzeitpunkt hinaus verstarb eine weitere Patientin nach mehreren Monaten adäquater Therapie an den neurologischen Folgen ihrer Ösophagusperforation, was die Mortalität auf $66 \%$ erhöhte.

Da die Ösophagusperforation trotz ihres seltenen Auftretens $(0,3 \%)$ mit einer hohen Mortalität (66\%) vergesellschaftet ist, sind Standards für Diagnostik und Therapie sowie Technologien zur Komplikationsvermeidung klinisch hoch relevant. Entsprechend analysierten und beschrieben wir den detaillierten klinischen Verlauf von 4 Patienten mit Ösophagusperforationen (3 nach chirurgischer Ablation, 1 nach katheterinterventioneller Ablation). Als Leitsymptome fanden sich Fieber, Leukozytose und mediastinitische Beschwerden 8-28 Tage nach Ablation. Eine rasche Sicherung der Diagnose mittels CT und wasserlöslichem Kontrastschluck sowie eine anschließende schnelle chirurgische Resektion des betroffenen Ösophagusabschnittes zeigten sich als Therapie der Wahl. Verzögerungen bei Diagnostik oder Therapie führten zu schweren neurologischen Schäden infolge Luftembolien. Aus gleichem Grund verbieten sich auch Gastroskopien oder transösophageale Echokardiographien.

Mit dem Ziel der Vermeidung potentieller Ösophagusperforationen rückten die anatomischen Nachbarschaftsbeziehungen von Ösophagus, linkem Vorhof und Zielarealen der Vorhofflimmerablation in das Zentrum des Interesses invasiver Elektrophysiologen. Diesbezüglich etablierten wir eine Methode zur elektroanatomischen Rekonstruktion des Ösophagus mittels eines über eine 
Magensonde eingebrachten Sensorkatheters. Auf diese Art und Weise konnte die dreidimensionale Position des Ösophagus im Verhältnis zur dreidimensionalen Anatomie des linken Vorhofes dargestellt werden. Enge Kontaktareale waren eindeutig zu identifizieren. Es zeigte sich eine hohe inter-individuelle Variabilität von Verlauf und Kontakt des Ösophagus. Insgesamt befanden sich bei über 50\% der Patienten Anteile der zirkumferentiellen Ablationslinien im Bereich von Kontaktarealen zum Ösophagus. Berichte über eine signifikante Mobilität des Ösophagus hinter dem linken Vorhof konnten wir in unseren Untersuchungen nicht bestätigen ${ }^{59}$. Sowohl periprozedural als auch bei Rezidiv-Eingriffen zeigte sich eine hohe intra-individuelle Stabilität der anatomischen Lage des Ösophagus. Mit der Visualisierung des Ösophagus innerhalb dreidimensionaler Mappingsysteme konnten Ablationsareale mit potentieller Gefährdung für den Ösophagus identifiziert werden. Mit einer Reduktion von Ablationsleistung und Ablationsdauer in den betroffenen Zielarealen wurde versucht, der gefährlichen Nachbarschaftsbeziehung gerecht zu werden. Für den Fall dabei inkompletter Ablationslinien wurden die Linienkonzepte so angepasst, dass Kontaktareale vermieden werden konnten. Abschließend muss festgestellt werden, dass trotz derartiger Vorsichtsmaßnahmen weitere Ösophagusperforationen aufgetreten sind. Aktuelle Entwicklungen zum Schutz des Ösophagus basieren ebenfalls auf einer Visualisierung der anatomischen Nachbarschaftsbeziehungen, gehen aber darüber hinaus, indem sie mittels Temperaturmessung zusätzlich funktionelle Informationen über den tatsächlichen Energietransfer in den Ösophagus zur Verfügung stellen. Im Rahmen dieser Untersuchungen zeigte es sich, das Überhitzungen und thermische Läsionen im Ösophagus nur schwach mit der verwendeten Ablationsleistung korrelieren ${ }^{60}$. Im klinischen Alltag hat sich daher die kombinierte Erfassung anatomischer und 
funktioneller Informationen als aktuell wichtigstes Verfahren zur Protektion des Ösophagus etabliert.

\section{EKG Monitoring von Vorhofflimmern}

Mit der Entwicklung und Verfeinerung verschiedener katheterinterventioneller Techniken zur kurativen Behandlung von Vorhofflimmern erhalten Definition, Erfassung und Vergleich von Ablationserfolg eine tragende Bedeutung. Vergleichbar mit der Behandlung anderer Rhythmusstörungen wäre das ideale Therapieergebnis eine vollständige Heilung der Arrhythmie in den meisten Patienten, und im Falle von Rezidiven eine verlässliche subjektive Wahrnehmung, die das Therapieversagen anzeigt. Die Katheterablation von Vorhofflimmern führt jedoch häufig nicht zu solch einem binären Ergebnis. Das Auftreten von asymptomatischen Flimmerepisoden ist sowohl klinisch als auch wissenschaftlich die größte Herausforderung für die postinterventionelle Nachsorge. Asymptomatische Episoden sind ein in der Gesamtheit der Vorhofflimmerpatienten bekanntes Phänomen ${ }^{48 ;} 49$. Da jedoch die symptomatische Beeinträchtigung unter der Rhythmusstörung nach wie vor die Hauptindikation für die Durchführung einer Katheterablation darstellt, repräsentieren Ablationspatienten eine hoch selektierte hoch symptomatische Subgruppe aller Vorhofflimmerpatienten. Innerhalb dieser Subgruppe wurde die subjektive Wahrnehmung der Arrhythmie lange Zeit als ausreichender Surrogat-Parameter für das tatsächliche Vorliegen der Rhythmusstörung gewertet.

Erstmals haben wir bei 114 Patienten die an hoch symptomatischem medikamentös therapierefraktärem Vorhofflimmern litten mittels serieller 7-Tage-LzEKGs und einem detaillierten Symptom-Tagebuch für den gesamten Aufzeichnungszeitraum des LzEKGs eine direkte Korrelation zwischen den subjektiven Beschwerden der 
Patienten und dem im LzEKG tatsächlich vorliegenden Rhythmus durchgeführt. In Summe wurde damit für mehr als 70.000 Stunden kontinuierlicher EKG-Registrierung Symptom mit Rhythmus korreliert. Vor Ablation wurden bei mehr als der Hälfte dieser an sich hoch symptomatischen Patienten auch asymptomatische ArrhythmieEpisoden detektiert. Nach Ablation kam es zu einer weiteren starken Zunahme an asymptomatischem Vorhofflimmern. Ein Drittel der Patienten mit ArrhythmieRezidiven war vollständig beschwerdefrei und konnte somit das Wiederauftreten der Rhythmusstörung selbst nicht identifizieren. Diese Daten unterstreichen, dass auch bei hoch symptomatischen Vorhofflimmerpatienten ein nur auf den subjektiven Symptomen der Patienten basiertes Rhythmusmonitoring völlig unzureichend ist, um sowohl das Auftreten als auch die Dauer der Rhythmusstörung genau zu erfassen. Damit stellt sich die Frage wie viel Rhythmusmonitoring ist notwendig, und wie sollte dieses durchgeführt werden.

Um dieser Frage nachzugehen haben wir in 2 weiteren Arbeiten den Einfluss der Aufzeichnungsdauer des LzEKGs auf die Detektionsrate von Vorhofflimmern untersucht und das Rhythmusmonitoring mittels seriellem 7-Tage-LzEKG gegenüber dem transtelephonischen EKG verglichen. Es zeigte sich, dass bei einer LzEKGDauer von weniger als 4 Tagen die Anzahl der Patienten, bei denen Vorhofflimmern detektiert wird, signifikant abnimmt. Mit einem 24-Stunden-LzEKG konnten gegenüber dem 7-Tage-LzEKG lediglich $60 \%$ der Patienten mit Vorhofflimmerrezidiven identifiziert werden. Aus der Perspektive der berichteten Erfolgsraten waren das serielle 7-Tage-LzEKG und die reguläre transtelephonische EKG-Übertragung gleichermaßen effektiv in der Identifizierung von Patienten mit Arrhythmie-Rezidiven. 
Trotz dieser für den klinischen Alltag wichtigen Ergebnisse ermöglichen beide Arbeiten keine endgültige Aussage darüber, wie viel Rhythmusmonitoring ein individueller Patient letztendlich benötigt und wie dieses durchgeführt werden sollte. Diese Unsicherheit resultiert aus dem Fehlen eines akkuraten Goldstandards. Alle Monitoring-Verfahren, die aktuell verfügbar sind und in den bisherigen Studien eingesetzt wurden, sind diskontinuierliche Monitoring-Verfahren mit Technologiebedingt nicht überwachten Zeiträumen zwischen den Phasen der EKG-Erfassung. Die wissenschaftliche und klinische Relevanz zusätzlich auftretender asymptomatischer Flimmer-Episoden innerhalb dieser nicht überwachten Zeiträume ist derzeit unklar und kann nur untersucht werden, wenn verlässliche Technologien für ein lückenloses kontinuierliches Monitoring über mehrere Monate verfügbar werden. Aktuell gibt es erste Ansätze für die Entwicklung solcher kontinuierlicher Monitoring-Technologien auf der Basis subkutan implantierbarer Ereignisrekorder mit speziellen Software-Algorithmen zur Detektion von Vorhofflimmern. Erste klinische Validierungs-Studien dieser Devices zeigten eine hohe Sensitivität (96\%) für die Detektion von Vorhofflimmern ${ }^{61}$. Die Spezifität war aber eingeschränkt durch die Fehldetektion von Muskelpotentialen. Bei limitierter EGM-Speicherkapazität ergibt sich daraus das Problem, dass bei längeren Monitoring-Perioden eine Erschöpfung des EGM-Speichers durch Fehldetektionen eintreten kann, und es am Ende unklar ist, ob der Patient nicht doch zusätzliche Vorhofflimmer-Episoden hatte, zu denen aber kein EGM existiert ${ }^{62}$. Telemedizinsche Applikationen haben prinzipiell das Potential, dieses Problem der Fehldetektionen bei limitiertem EGM-Speicher zu umgehen und den gesamten Monitoring-Prozess in weiten Teilen zu automatisieren. Daher sind gegenwärtig weitere Entwicklungen nötig, bevor ein akkurates 
kontinuierliches Monitoring von Vorhofflimmerpatienten auch technisch zuverlässig möglich ist.

Der Bedarf für ein kontinuierliches Rhythmusmonitoring bei Vorhofflimmerpatienten geht weit über die alleinige Beurteilung der Erfolgsraten der Katheterablation hinaus. Die grundsätzliche Frage der prognostischen Überlegenheit der Rhythmus- oder Frequenzkontrolle bei Patienten mit Vorhofflimmern kann nur bei kontinuierlicher EKG-Dokumentation tatsächlich auftretender Arrhythmierezidive schlüssig beantwortet werden. Darüberhinaus böte ein kontinuierliches Rhythmusmonitoring die Möglichkeit, abgestimmt auf verschiedene klinische Szenarien wissenschaftlich fundierte Standards für Dauer und Methodik des Vorhofflimmermonitorings zu definieren. Auch die Entscheidung zur oralen Antikoagulation wäre zielgenauer möglich, wenn nicht klinische Surrogatparameter $\left(\mathrm{CHADS}_{2}\right.$ score) sondern das tatsächliche Auftreten der Rhythmusstörung als Indikation verwendet werden könnte. Kürzlich publizierte Daten zum signifikanten Vorkommen asymptomatischen Vorhofflimmerns bei Patienten mit kryptogenem Schlaganfall unterstützen die Bedeutung dieser Entwicklung ${ }^{63}$. 


\section{Literaturverzeichnis}

1. Benjamin EJ, Wolf PA, D’Agostino RB, Silbershatz H, Kannel WB, Levy D. Impact of atrial fibrillation on the risk of death: The Framingham Heart Study. Circulation 1998; 98: 946-952

2. Miyasaka Y, Barnes ME, Gersh BJ, Cha SS, Bailey KR, Abhayaratna WP, Seward JB, Tsang TS. Secular trends in incidence of atrial fibrillation in Olmsted County, Minnesota, 1980 to 2000 , and implications on the projections for future prevalence. Circulation 2006; 114: 119-125.

3. Mant J, Hobbs FD, Fletcher K, Roalfe A, Fitzmaurice D, Lip GY, Murray E; BAFTA investigators; Midland Research Practices Network (MidReC). Warfarin versus aspirin for stroke prevention in an elderly community population with atrial fibrillation (the Birmingham Atrial Fibrillation Treatment of the Aged Study, BAFTA): a randomised controlled trial. Lancet 2007; 370: 493-503.

4. Fuster V, Rydén LE, Cannom DS, Crijns HJ, Curtis AB, Ellenbogen KA, Halperin JL, Le Heuzey JY, Kay GN, Lowe JE, Olsson SB, Prystowsky EN, Tamargo JL, Wann S, Smith SC Jr, Jacobs AK, Adams CD, Anderson JL, Antman EM, Halperin JL, Hunt SA, Nishimura R, Ornato JP, Page RL, Riegel B, Priori SG, Blanc JJ, Budaj A, Camm AJ, Dean V, Deckers JW, Despres C, Dickstein K, Lekakis J, McGregor K, Metra M, Morais J, Osterspey A, Tamargo JL, Zamorano JL; American College of Cardiology/American Heart Association Task Force on Practice Guidelines; European Society of Cardiology Committee for Practice Guidelines; European Heart Rhythm 
Association; Heart Rhythm Society. ACC/AHA/ESC 2006 Guidelines for the Management of Patients with Atrial Fibrillation: a report of the American College of Cardiology/American Heart Association Task Force on Practice Guidelines and the European Society of Cardiology Committee for Practice Guidelines (Writing Committee to Revise the 2001 Guidelines for the Management of Patients With Atrial Fibrillation): developed in collaboration with the European Heart Rhythm Association and the Heart Rhythm Society. Circulation 2006; 114: e257-354.

5. Waldo AL, van Wagoner DR. Atrial Fibrillation. In: Spooner PM, Rosen MR (Hrsg) Foundations of Cardiac Arrhythmias. Marcel Dekker, Inc., New York, $2001 ; 479-512$.

6. Haissaguerre M, Jais P, Shah DC, Takahashi A, Hocini M, Quiniou G, Garrique S, Le Mouroux A, Le Metayer P, Clementy J. Spontaneous Initiation Of Atrial Fibrillation By Ectopic Beats Originating In The Pulmonary Veins. N Engl J Med 1998; 339: 659-666.

7. Moe GK, Abildskov JA. Atrial fibrillation as a self-sustained arrhytmia independent of focal discharge. Am Heart J 1959; 58: 59-70.

8. Allessie MA, Lammers WJEP, Bonke FIM, Hollen J. Experimental evaluation of Moe's multiple wavelet hypothesis of atrial fibrillation. In: Zipes DP, Jalife J (Hrsg) Cardiac Elektrophysiology and Arrhythmias. Grune \& Stratton, Orlando FL, 1985; 265-267. 
9. Kumagai K, Khrestian C, Waldo AL. Simultaneous Multisite Mapping Studies During Induced Atrial Fibrillation in the Sterile Pericarditis Model. Circulation 1997; 95: 511-521.

10. Sueda T, Nagata H, Shikata H, Orihashi K, Morita S, Sueshiro M, Okada K, Matsuura Y. Simple left atrial procedure for chronic atrial fibrillation in patients with isolated mitral valve disease. Ann Thorac Surg 1996; 62: 1796-1800.

11.Skane AC, Mandapati R, Berenfeld O, Davidenko JM, Jalife J. Spatiotemporal Periodicity During Atrial Fibrillation in the Isolated Sheep Heart. Circulation 1998; 98: 1236-1248.

12. Fetsch T, Bauer P, Engberding R, Koch HP, Lukl J, Meinertz T, Oeff M, Seipel L, Trappe HJ, Treese N, Breithardt G. Prevention of atrial fibrillation after cardioversion: results of the PAFAC trial. Eur Heart J 2004; 25: 1385-1394.

13. Van Gelder IC, Hagens VE, Bosker HA, Kingma JH, Kamp O, Kingma T, Said SA, Darmanata JL, Timmermans AJ, Tijssen JG, Crijns HJ. A comparison of rate control and rhythm control in patients with recurrent persistent atrial fibrillation. N Engl J Med 2002; 347: 1834-1440.

14. Wyse DG, Waldo AL, DiMarco JP, Domanski MJ, Rosenberg Y, Schron EB, Kellen JC, Greene HL, Mickel MC, Dalquist JE, Corley SD. A comparison of rate control and rhythm control in patients with atrial fibrillation. $\mathrm{N}$ Engl $\mathrm{J}$ Med 2002; 347: 1825-1833.

15.Singh BN, Singh SN, Reda DJ, Tang XC, Lopez B, Harris CL, Fletcher RD, Sharma SC, Atwood JE, Jacobson AK, Lewis HD Jr, Raisch DW, Ezekowitz MD; Sotalol Amiodarone Atrial Fibrillation Efficacy Trial (SAFE-T) 
Investigators. Amiodarone versus sotalol for atrial fibrillation. $\mathrm{N}$ Engl $\mathrm{J}$ Med 2005; 352: 1861-1872.

16. Waldo AL. A perspective on antiarrhythmic drug therapy to treat atrial fibrillation: there remains an unmet need. Am Heart J 2006; 151: 771-778.

17. Calkins H, Brugada J, Packer DL, Cappato R, Chen SA, Crijns HJ, Damiano RJ Jr, Davies DW, Haines DE, Haissaguerre M, lesaka Y, Jackman W, Jais P, Kottkamp H, Kuck KH, Lindsay BD, Marchlinski FE, McCarthy PM, Mont JL, Morady F, Nademanee K, Natale A, Pappone C, Prystowsky E, Raviele A, Ruskin JN, Shemin RJ; Heart Rhythm Society; European Heart Rhythm Association; European Cardiac Arrhythmia Society; American College of Cardiology; American Heart Association; Society of Thoracic Surgeons. HRS/EHRA/ECAS expert consensus statement on catheter and surgical ablation of atrial fibrillation: recommendations for personnel, policy, procedures and follow-up. A report of the Heart Rhythm Society (HRS) Task Force on Catheter and Surgical Ablation of Atrial Fibrillation developed in partnership with the European Heart Rhythm Association (EHRA) and the European Cardiac Arrhythmia Society (ECAS); in collaboration with the American College of Cardiology (ACC), American Heart Association (AHA), and the Society of Thoracic Surgeons (STS). Endorsed and approved by the governing bodies of the American College of Cardiology, the American Heart Association, the European Cardiac Arrhythmia Society, the European Heart Rhythm Association, the Society of Thoracic Surgeons, and the Heart Rhythm Society. Europace 2007; 9:335-379. 
18. Hsu LF, Jaïs P, Sanders P, Garrigue S, Hocini M, Sacher F, Takahashi Y, Rotter M, Pasquié JL, Scavée C, Bordachar P, Clémenty J, Haïssaguerre M. N Engl J Med 2004; 351: 2373-2383.

19.Cox JL, Schuessler RB, D'Agostino HJ Jr., Stone CM, Chang BC, Cain ME. The surgical treatment of atrial fibrillation. III Development of a definite surgical procedure. J Thorac Cardiovasc Surg 1991; 101: 569-583.

20. Hindricks G, Mohr FW, Autschbach R, Kottkamp H. Antiarrhythmic Surgery for Treatment of Atrial Fibrillation - New Concepts. Thorac Cardiovasc Surg 1999; 47: 365-369.

21. Kottkamp H, Hindricks G, Autschbach R, Krauss B, Strasser B, Schirdewahn P, Fabricius A, Schuler G, Mohr FW. Specific Linear Left Atrial Lesions in Atrial Fibrillation: Intraoperative Radiofrequency Ablation Using Minimally Invasive Surgical Techniques. J Am Coll Cardiol 2002; 40: 475-480.

22. Mohr FW, Fabricius AM, Falk $V$ et al. Curative treatment of atrial fibrillation with intraoperative radiofrequency ablation: Short-term and midterm results. $J$ Thorac Cardiovasc Surg 2002; 123: 919-927.

23.Tada H, Ilto S, Naito S, Hasegawa Y, Kurosaki K, Ezure M, Kaneko T, Oshima S, Taniguchi K, Nogami A. Pacing Clin Electrophysiol 2005; 28: 73-77.

24. Vicol C; Kur F; Eifert S; Oberhoffer M, Nollert G, Wintersperger B; Reichart B. Bipolar irrigated radiofrequency ablation of the posterior-inferior left atrium and coronary sinus is feasible and safe. Heart Surg Forum 2004; 7: 535-538. 
25.Deneke T, Khargi K, Lemke B, Lawo T, Lindstaedt M, Germing A, Brodherr T, Bösche L, Mügge A, Laczkovics A, Grewe PH, Fritz M. Intra-operative cooledtip radiofrequency linear atrial ablation to treat permanent atrial fibrillation. Eur Heart J 2007; 28: 2909-2914.

26.Jaïs P, Haïssaguerre M, Shah DC, Chouairi S, Gencel L, Hocini M, Clémenty J. A focal source of atrial fibrillation treated by discrete radiofrequency ablation. Circulation 1997; 95 :572-576.

27. Oral H, Knight BP, Tada H, Ozaydin M, Chugh A, Hassan S, Scharf C, Lai SW, Greenstein R, Pelosi F Jr, Strickberger SA, Morady F. Pulmonary Vein Isolation for Paroxysmal and Persistent Atrial Fibrillation. Circulation 2002; 105: 1077-1081.

28.Pappone C, Rosanio S, Oreto G, Tocchi M, Gugliotta F, Vicedomini G, Salvati A, Dicandia C, Mazzone P, Santinelli V, Gulletta S, Chierchia S. Circumferential Radiofrequency Ablation of Pulmonary Vein Ostia. A New Anatomic Approach for Curing Atrial Fibrillation. Circulation 2000; 102: 26192628.

29.Pappone C, Oreto G, Rosanio S, Vicedomini G, Tocchi M, Gugliotta F, Salvati A, Dicandia C, Calabrò MP, Mazzone P, Ficarra E, Di Gioia C, Gulletta S, Nardi S, Santinelli V, Benussi S, Alfieri O. Atrial Electroanatomic Remodeling After Circumferential Radiofrequency Pulmonary Vein Ablation. Efficacy of an Anatomic Approach in a Large Cohort of Patients With Atrial Fibrillation. Circulation 2001; 104: 2539-2544. 
30.Ben-Haim SA, Osadchy D, Schuster I, Gepstein L, Hayam G, Josephson ME. Nonfluoroscopic, in vivo navigation and mapping technology. Nat Med 1996; 2: 1393-1395.

31. Wittkampf FH, Wever EF, Derksen R, Wilde AA, Ramanna H, Hauer RN, Robles de Medina EO. LocaLisa - New Technique for Real-Time 3Dimensional Localization of Regular Intracardiac Electrodes. Circulation 1999; 99: 1312-1317.

32.Grunert P, Darabi K, Espinosa J, Filippi R. Computer-aided navigation in neurosurgery. Neurosurg Rev 2003; 26: 73-99.

33. Kistler PM, Earley MJ, Harris S, Abrams D, Ellis S, Sporton SC, Schilling RJ. Validation of three-dimensional cardiac image integration: use of integrated CT image into electroanatomic mapping system to perform catheter ablation of atrial fibrillation. J Cardiovasc Electrophysiol 2006; 17: 341-348.

34.Kistler PM, Rajappan K, Harris S, Earley MJ, Richmond L, Sporton SC, Schilling RJ. Eur Heart J 2008; 29: 2957-2958.

35. Chae S, Oral H, Good E, Dey S, Wimmer A, Crawford T, Wells D, Sarrazin JF, Chalfoun N, Kuhne M, Fortino J, Huether E, Lemerand T, Pelosi F, Bogun F, Morady F, Chugh A. Atrial tachycardia after circumferential pulmonary vein ablation of atrial fibrillation: mechanistic insights, results of catheter ablation, and risk factors for recurrence. J Am Coll Cardiol 2007; 50: 1788 -1790.

36. O'Neill MD, Wright M, Knecht S, Jaïs $P$, Hocini M, Takahashi $Y$, Jönsson A, Sacher F, Matsuo S, Lim KT, Arantes L, Derval N, Lellouche N, Nault I, Bordachar P, Clémenty J, Haïssaguerre M. Long-term follow-up of persistent 
atrial fibrillation ablation using termination as a procedural endpoint. Eur Heart J 2009; 30: 1105-1112.

37.Pappone C, Vicedomini G, Manguso F, Gugliotta F, Mazzone P, Gulletta S, Sora N, Sala S, Marzi A, Augello G, Livolsi L, Santagostino A, Santinelli V. Robotic magnetic navigation for atrial fibrillation ablation. J Am Coll Cardiol 2006; 47: 1390-1400.

38. Di Biase L, Fahmy TS, Patel D, Bai R, Civello K, Wazni OM, Kanj M, Elayi CS, Ching CK, Khan M, Popova L, Schweikert RA, Cummings JE, Burkhardt JD, Martin DO, Bhargava M, Dresing T, Saliba W, Arruda M, Natale A. Remote magnetic navigation: human experience in pulmonary vein ablation. J Am Coll Cardiol 2007; 50: 868-874.

39. Reddy VY, Neuzil P, Malchano ZJ, Vijaykumar R, Cury R, Abbara S, Weichet J, McPherson CD, Ruskin JN. View-synchronized robotic image-guided therapy for atrial fibrillation ablation: experimental validation and clinical feasibility. Circulation 2007; 115: 2705-2714.

40.Wazni OM, Marrouche NF, Martin DO, Verma A, Bhargava M, Saliba W, Bash D, Schweikert R, Brachmann J, Gunther J, Gutleben K, Pisano E, Potenza D, Fanelli R, Raviele A, Themistoclakis S, Rossillo A, Bonso A, Natale A: Radiofrequency ablation vs antiarrhythmic drugs as firstline treatment of symptomatic atrial fibrillation: A randomized trial. JAMA 2005; 293: 2634-2640.

41.Oral H, Pappone C, Chugh A, Good E, Bogun F, Pelosi F Jr, Bates ER, Lehmann MH, Vicedomini G, Augello G, Agricola E, Sala S, Santinelli V, 
Morady F. Circumferential pulmonary-vein ablation for chronic atrial fibrillation. N Engl J Med 2006; 354: 934-941.

42. Cappato R, Calkins H, Chen SA, Davies W, lesaka Y, Kalman J, Kim YH, Klein G, Packer D, Skanes A. Worldwide survey on the methods, efficacy, and safety of catheter ablation for human atrial fibrillation. Circulation 2005; 111 : 1100-1105.

43.Bertaglia E, Zoppo F, Tondo C, Colella A, Mantovan R, Senatore G, Bottoni N, Carreras G, Cor`o L, Turco P, Mantica M, Stabile G. Early complications of pulmonary vein catheter ablation for atrial fibrillation: A multicenter prospective registry on procedural safety. Heart Rhythm 2007; 4: 1265-1271.

44. Corrado A, Patel D, Riedlbauchova L, Fahmy TS, Themistoclakis S, Bonso A, Rossillo A, Hao S, Schweikert RA, Cummings JE, Bhargava M, Burkhardt D, Saliba W, Raviele A, Natale A: Efficacy, safety, and outcome of atrial fibrillation ablation in septuagenarians. J Cardiovasc Electrophysiol 2008; 19: 807-811.

45.Zado E, Callans DJ, Riley M, Hutchinson M, Garcia F, Bala R, Lin D, Cooper J, Verdino R, Russo AM, Dixit S, Gerstenfeld E, Marchlinski FE: Long-term clinical efficacy and risk of catheter ablation for atrial fibrillation in the elderly. $\mathrm{J}$ Cardiovasc Electrophysiol 2008; 19: 621-626.

46. Doll N, Borger MA, Fabricius A, Stephan S, Gummert J, Mohr FW, Hauss J, Kottkamp H, Hindricks G. Esophageal perforation during left atrial radiofrequency ablation: Is the risk too high? J Thorac Cardiovasc Surg 2003; 125: 836-842. 
47.Pappone C, Oral H, Santinelli V, Vicedomini G, Lang CC, Manguso F, Torracca L, Benussi S, Alfieri O, Hong R, Lau W, Hirata K, Shikuma N, Hall B, Morady F. Atrio-esophageal fistula as a complication of percutaneous transcatheter ablation of atrial fibrillation. Circulation 2004; 109: 2724-2726.

48. Israel CW, Gronefeld G, Ehrlich JR, Li YG, Hohnloser SH. Long-term risk of recurrent atrial fibrillation as documented by an implantable monitoring device: implications for optimal patient care. J Am Coll Cardiol. 2004; 43: 47-52.

49. Savelieva I, Camm AJ. Clinical relevance of silent atrial fibrillation: prevalence, prognosis, quality of life, and management. J Interv Card Electrophysiol 2000; 4: 369-382.

50.Kirchhof P, Auricchio A, Bax J, Crijns H, Camm J, Diener HC, Goette A, Hindricks G, Hohnloser S, Kappenberger L, Kuck KH, Lip GY, Olsson B, Meinertz T, Priori S, Ravens U, Steinbeck G, Svernhage E, Tijssen J, Vincent A, Breithardt G. Outcome parameters for trials in atrial fibrillation: recommendations from a consensus conference organized by the German Atrial Fibrillation Competence NETwork and the European Heart Rhythm Association. Europace. 2007; 9: 1006-1023.

51.Schmidt B, Asbach S, Schweika O, Zehender M, Bode C, Faber TS. Atrial fibrillation reduces the atrial impedance amplitude during cardiac cycle: a novel detection algorithm to improve recognition of atrial fibrillation in pacemaker patients. Europace 2007; 9: 812-816.

52.Saliba W, Reddy VY, Wazni O, Cummings JE, Burkhardt JD, Haissaguerre M, Kautzner J, Peichl P, Neuzil P, Schibgilla V, Noelker G, Brachmann J, Di BL, 
Barrett $C$, Jais $P$, Natale A. Atrial fibrillation ablation using a robotic catheter remote control system: initial human experience and long-term follow-up results. J Am Coll Cardiol 2008; 51: 2407-2411.

53. Reddy VY, Neuzil P, d'Avila A, Laragy M, Malchano ZJ, Kralovec S, Kim SJ, Ruskin JN. Balloon catheter ablation to treat paroxysmal atrial fibrillation: what is the level of pulmonary venous isolation? Heart Rhythm 2008; 5: 353-360.

54.Cheema A, Dong J, Dalal D, Marine JE, Henrikson CA, Spragg D, Cheng A, Nazarian S, Bilchick K, Sinha S, Scherr D, Almasry I, Halperin H, Berger R, Calkins $\mathrm{H}$. Incidence and time course of early recovery of pulmonary vein conduction after catheter ablation of atrial fibrillation. $J$ Cardiovasc Electrophysiol 2007; 18: 387-91.

55. Yokoyama K, Nakagawa H, Shah DC, Lambert H, Leo G, Aeby N, Ikeda A, Pitha JV, Sharma T, Lazzara R, Jackman WM. Novel contact force sensor incorporated in irrigated radiofrequency catheter predicts lesion size and incidence of steam pop and thrombus. Circ Arrhythmia Electrophysiol. 2008; 1: $354-362$

56.Pratola C, Baldo E, Notarstefano P, Toselli T, Ferrari R. Radiofrequency ablation of atrial fibrillation: is the persistence of all intraprocedural targets necessary for long-term maintenance of sinus rhythm? Circulation 2008; 117: 136-143.

57. Stabile G, Bertaglia E, Senatore G, De Simone A, Zoppo F, Donnici G, Turco P, Pascotto P, Fazzari M, Vitale DF. Catheter ablation treatment in patients with drug-refractory atrial fibrillation: a prospective, multi-centre, randomized, 
controlled study (Catheter Ablation For The Cure Of Atrial Fibrillation Study). Eur Heart J 2006; 27: 216-221

58.Pappone C, Augello G, Sala S, Gugliotta F, Vicedomini G, Gulletta S, Paglino G, Mazzone P, Sora N, Greiss I, Santagostino A, LiVolsi L, Pappone N, Radinovic A, Manguso F, Santinelli V. A randomized trial of circumferential pulmonary vein ablation versus antiarrhythmic drug therapy in paroxysmal atrial fibrillation: the APAF Study. J Am Coll Cardiol 2006; 48: 2340-2347.

59. Han J, Good E, Morady F, Oral H. Esophageal migration during left atrial catheter ablation for atrial fibrillation. Circulation 2004; 110: e528.

60.Gaspar T, Piorkowski C, Staab C, Arya A, Bollmann A, Esato M, Husser D, Kircher S, Sommer P, Hindricks G. New insights into intraesophageal temperature monitoring during AF catheter ablation. Heart Rhythm 2008; 5 suppl.: 169 (abstract).

61. Hindricks G, Pokushalov E, Urban L, et al. Performance of a new Implantable Cardiac Monitor in Detecting and Quantifying Atrial Fibrillation - Results of the XPECT Trial. Data under advanced revision process for Circ Arrhythm Electrophysiol 2009

62. Eitel C, Hindricks G, Husser D, Hilbert S, Frühauf M, Sommer P, Gaspar T, Piorkowski T. Comparison of AF detection accuracy between an implantable monitoring device (Reveal XT) and 7-day-holter monitoring. Heart Rhythm 2009; 6 suppl.: 160 (abstract). 
63. Tayal AH, Tian M, Kelly KM, et al. Atrial fibrillation detected by mobile cardiac outpatient telemetry in cryptogenic TIA or stroke. Neurology 2008; 71: 16961701. 


\section{Erklärung}

Habilitationsverfahren von Dr. med. Christopher Piorkowski

Hiermit erkläre ich, die vorliegende Habilitationsschrift selbständig und ohne unerlaubte fremde Hilfe angefertigt zu haben. Ich habe keine anderen als die im Literaturverzeichnis angeführten Quellen benutzt und sämtliche Textstellen, die wörtlich oder sinngemäß aus veröffentlichten oder unveröffentlichten Schriften entnommen wurden und alle Angaben, die auf mündlichen Auskünften beruhen, als solche kenntlich gemacht. Ebenfalls sind alle von anderen Personen bereitgestellten Materialien oder erbrachten Dienstleistungen als solche gekennzeichnet. 


\section{Lebenslauf}

ANGABEN ZUR PERSON

- Name: Christopher Piorkowski

- geboren: am 05.02.1975

- Anschrift: August-Bebel-Str. 62, 04275 Leipzig

SCHULAUSBILDUNG

Juni 1993 Abitur am 1. Städtischen Gymnasium in Cottbus

Ab Oktober 1993 Studium der Humanmedizin - Humboldt-Universität Berlin

August 1995 Ärztliche Vorprüfung (Physikum)

August 1996 1. Abschnitt der Ärztlichen Prüfung

August $\quad 1998$ 2. Abschnitt der Ärztlichen Prüfung

November 1999 3. Abschnitt der Ärztlichen Prüfung

Juli

2001 Ärztlichen Approbation

Oktober 1998 1. Teil des Amerikanischen Staatsexamens (USMLE I)

April $\quad 2001$ 2. Teil des Amerikanischen Staatsexamens (USMLE II)

September 2002 3. Teil des Amerikanischen Staatsexamens (CSA)

Ab März 1996 Stipendium der „Studienstiftung des Deutschen Volkes“

Ab Januar 2000 AiP bzw. Assistenzarzt in der Inneren Abteilung des Herzzentrum Cottbus

Ab Mai 2002 Assistenzarzt in der gemeinsamen Inneren Abteilung des Herzzentrum und Parkkrankenhaus Leipzig-Südost

Mai 2006 Erfolgreiche Prüfung zum Facharzt für Innere Medizin

Juni 2007 Erfolgreiche Prüfung zur Subspezialisierung Kardiologie

Ab August 2005 Funktionsoberarzt der Abteilung für Rhythmologie im Herzzentrum Leipzig

Ab Sept. 2007 Leitender Oberarzt der Abteilung für Rhythmologie im Herzzentrum Leipzig 
08/97 - 08/98 Studium an der „Medical School of the University of Bristol“ (UK) mit einem Stipendium der Studienstiftung

08/98 - 10/98 Studium an der „Rush Presbytarian Medical School Chicago“"

06/99 - 09/99 Studium an der „University Coimbra“ (Portugal) im Fach Neurologie/Neurochirurgie des Praktischen Jahres

PROMOTION

Juli 1997 erfolgreiche Verteidigung einer Promotionsarbeit zum Thema:

„Vergleichende Untersuchungen von Carvedilol und Metoprolol am insuffizienten humanen Myokard - Ein Beitrag zum Pathomechanismus und der Therapie der Herzinsuffizienz"

nach 2 Jahren experimenteller Arbeit an der Medizinischen Klinik I der Charité unter PD Dr. med. Modersohn

\section{GUTACHTERTÄTIGKEIT FÜR FACHZEITSCHRIFTEN}

- Heart Rhythm Journal

- Journal of Cardiovascular Electrophysiology

- Europace

- European Heart Journal

- European Journal of Heart Failure

- International Journal of Cardiovascular Imaging

- CardioVascular \& Interventional Radiology

\section{MitgliedSCHAFTEN IN FACHGESELLSCHAFTEN}

- Deutsche Gesellschaft für Kardiologie

- European Society of Cardiology

Leipzig, den 15. November 2009

Dr. med. Christopher Piorkowski 


\section{Danksagung}

Zu aller erst möchte ich mich bei meinen Eltern und meinem Bruder bedanken, die mir immer mit Rat zur Seite standen, mir mein Studium ermöglichten und mich auch später eng auf meinem beruflichen und privaten Weg begleiteten. Ebenso möchte ich meiner Freundin Judith Sitzy danken, die mich stets liebevoll unterstütze. Ohne sie alle wäre ich niemals an diesen Punkt gelangt.

Mein ganz besonderer Dank gilt meinem Freund und Lehrer Gerhard Hindricks, der mir beibrachte was ich heute über Elektrophysiologie weiß, der mich an wissenschaftliches Arbeiten heranführte, mir das Thema für diese Habilitation gab, und der mich auch persönlich immer eng begleitete.

Ebensolcher Dank gilt Hans Kottkamp, der in seiner Zeit in Leipzig zusammen mit Gerhard Hindricks meine Sicht auf die Welt der Elektrophysiologie formte, mich auf intensivste Art förderte und forderte, und dessen analytische Fähigkeiten ich stets schätze und fürchtete.

Ich möchte allen ärztlichen und nichtärztlichen Kollegen im Herzzentrum danken, ganz besonders Julia Fürstenhoff und Anke Eidner, die mir in der täglichen Arbeit Vertrauen und Freundschaft entgegenbrachten, und die mir auf vielfältigste Art und Weise geholfen haben.

Nicht zuletzt möchte ich mich bei Herrn Prof. Schuler für die hilfreiche und konstruktive Unterstützung während der Habilitation sowie für das mir entgegen gebrachte Vertrauen bedanken. 